Florida International University FIU Digital Commons

3-12-2008

\title{
Rich and poor, white and black, slave and free : the social history of Cuba's tobacco farmers, 1763-1817
}

Charlotte A. Cosner

Florida International University

DOI: $10.25148 /$ etd.FI14061527

Follow this and additional works at: https:// digitalcommons.fiu.edu/etd

Part of the Latin American History Commons

\section{Recommended Citation}

Cosner, Charlotte A., "Rich and poor, white and black, slave and free : the social history of Cuba's tobacco farmers, 1763-1817" (2008). FIU Electronic Theses and Dissertations. 2659.

https://digitalcommons.fiu.edu/etd/2659 
FLORIDA INTERNATIONAL UNIVERSITY

Miami, Florida

RICH AND POOR, WHITE AND BLACK, SLAVE AND FREE:

THE SOCIAL HISTORY OF CUBA'S TOBACCO FARMERS, 1763-1817

A dissertation submitted in partial fulfillment of the

requirements for the degree of

DOCTOR OF PHILOSOPHY

in

HISTORY

by

Charlotte A. Cosner

2008 
To: Dean Kenneth Furton

College of Arts and Sciences

This dissertation, written by Charlotte A. Cosner, and entitled Rich and Poor, White and Black, Slave and Free: The Social History of Cuba's Tobacco Farmers, 1763-1817, having been approved in respect to style and intellectual content, is referred to you for judgment.

We have read this dissertation and recommend that it be approved.

Darden Asbury Pyron

N. David Cook

Lisandro Perez

Sherry Johnson, Major Professor

Date of Defense: March 12, 2008

The dissertation of Charlotte A. Cosner is appr red.

Dean Kenneth Furton College of Arts and Sciences

Dean George Walker University Graduate School

Florida International University, 2008 
(C) Copyright 2008 by Charlotte A. Cosner

All rights reserved. 


\section{DEDICATION}

This dissertation is dedicated to the memories of my father, Raymond L. Cosner, and grandfather, Lester V. Cosner, the two men who first taught me about tobacco.

"Daddy, I kept my promise." 


\section{ACKNOWLEDGMENTS}

Without the personal and academic support from many people and institutions, this project never would have been realized. I gratefully acknowledge the financial support from several institutions including the Lydia Cabrera Award Committee of the Conference on Latin American History, the Jay I. Kislak Foundation, the Escuela de Estudios Hispanoaméricanos, the Department of History and the Cuban Research Institute of Florida International University, and the Ford Foundation.

I was lucky enough to have access to archives in Spain, the United States, and Cuba. The staff and directors of the Archivo General de Indias, Escuela de Estudios Hispanoámericanos, the Archivo Nacional de Cuba, the Archivo Historico Provincial Pinar del Río, the Special Collections of the Otto G. Richter Library at the University of Miami in Coral Gables, Florida, and Special Collections of the Dorothea and Steven Green Library at Florida International University were gracious and extremely helpful in making my time in the archives not only productive, but also enjoyable.

My academic debts are many. Early encouragement and advice came while I was still completing my bachelor's degree. At Virginia Commonwealth University, Dr.

Harold E. Greer, Jr.'s classes first introduced me to Latin American history. Colleagues Norman C. McLeod, Jr. and Guy R. Swanson at the Museum and White House of the Confederacy helped to convince me to attend graduate school. My interest in Cuban tobacco began with Dr. Kris E. Lane's colonial Latin American history class at the University of Miami. His enthusiastic response to a paper on the subject started what would eventually become this dissertation. Dr. Jean Stubbs and the late Dr. Enrique 
Baloyra took early interest in my project and were instrumental in providing advice and encouragement. Faculty, staff, and fellow students in the History Department at Florida International University gave me a warm welcome in 2000 and have been my steadfast academic family ever since. The members of my dissertation committee--Dr. Sherry Johnson, Dr. Noble David Cook, Dr. Darden A. Pyron, and Dr. Lisandro Pérez--always encouraged and motivated me, and were patient when other "projects" demanded my attention. I could never have asked for a better chair and mentor than Dr. Johnson. Her unwavering support and encouragment made this all possible, and I am eternally grateful. Yet, some of the greatest debts incurred are those to my friends and family. Through both the high and rough spots, they have stood by and encouraged me, and never let me give up. Particular thanks goes to my parents, Raymond and Hazel Cosner, John C. and Ruby Kelley, Robert Burton, and Nora Leal. Ultimately, this would never have been possible, or mean as much, without the help, support, and love of my husband, Rick Cardona, and our three children, Patrick, Virginia, and Adam. 
ABSTRACT OF THE DISSERTATION

RICH AND POOR, WHITE AND BLACK, SLAVE AND FREE:

THE SOCIAL HISTORY OF CUBA'S TOBACCO FARMERS, 1763-1817

by

Charlotte A. Cosner

Florida International University, 2008

Miami, Florida

Professor Sherry Johnson, Major Professor

Tobacco was of primary importance to Spain, and its impact on Cuba's economy and society was greater than just the numbers of farms, workers, or production, demonstrated by the Spanish crown's outlay of monies for capital assets, bureaucrats' salaries, and payments to farmers for their crop. This study is a micro- and macro-level study of rural life in colonial Cuba and the interconnected relationships among society, agricultural production, state control, and the island's economic development.

By placing Cuba's tobacco farmers at the forefront of this social history, this work revisits and offers alternatives to two prevailing historiographical views of rural Cuba from 1763 (the year Havana returned to Spanish control following the Seven Years' War) to 1817 (the final year of the 100-year royal monopoly on Cuban tobacco). Firstly, it argues against the primacy of sugar over other agricultural crops, a view that has shaped decades of scholarship, and challenges the thesis which maintains the Cuban tobacco farmer was almost exclusively poor, white, and employed free labor, rather than slaves, in the production of their crop. 
This study establishes the importance of tobacco as an agricultural product, and argues that Cuban tobacco growers were a heterogeneous group, revealing the role that its cultivation may have played in helping some slaves earn their freedom. 


\section{TABLE OF CONTENTS}

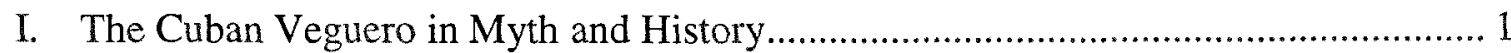

The Early History of Cuba's Most Important "Weed"'.............................................. 10

The Myth of the Cuban Veguero: Poor, White, and Isleño ....................................... 16

A New, Sugar-Free Approach to Cuban History..................................................... 23

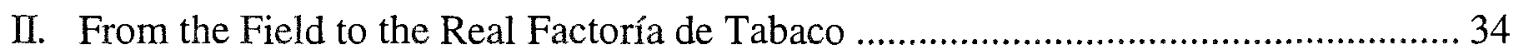

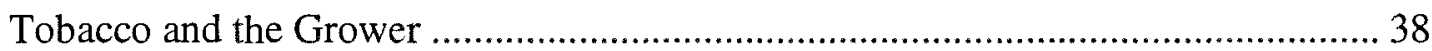

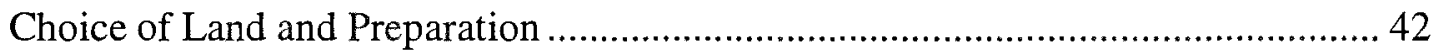

Seed Beds, Sowing, and Transplanting ................................................................... 45

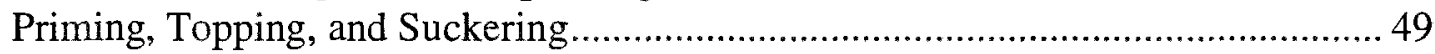

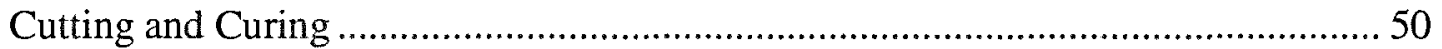

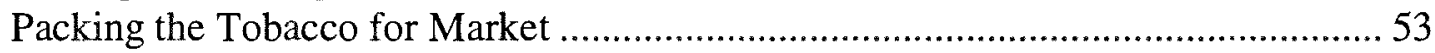

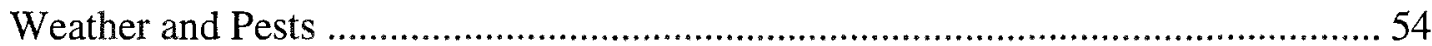

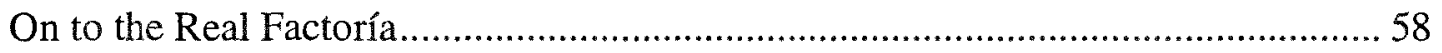

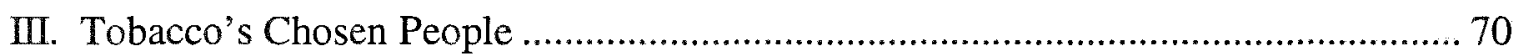

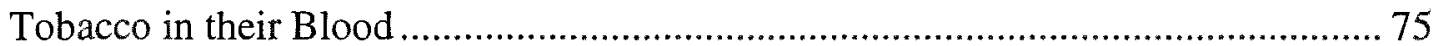

The Historiographical Veguero: Poor, White and Canary Islander.......................... 76

The Lost Historical Vegueros: The Slave Vegueros …............................................. 86

The Free Vegueros of Color ............................................................................... 97

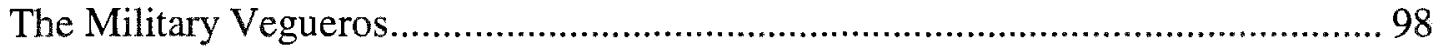

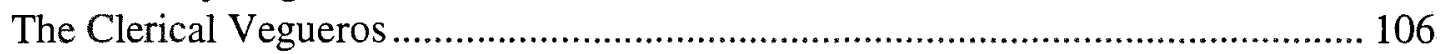

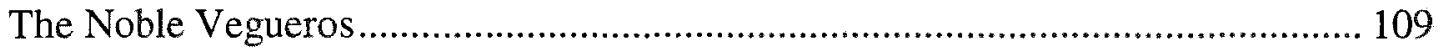

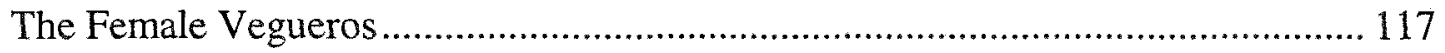

IV. A View Down Tobacco Road: A Case Study of Pinar del Río............................... 122

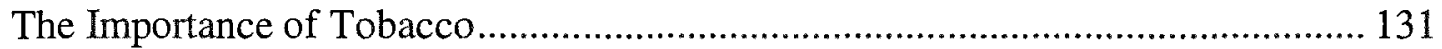

A Difficult Life for Filipinas' "Buena Gente"..................................................... 136

Tobacco's Chosen People.................................................................................... 142

The Interconnected Nature of Tobacco Cultivation ............................................. 158

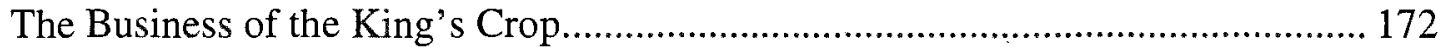

Contraband and the Lure of the Devil's Weed.................................................... 174

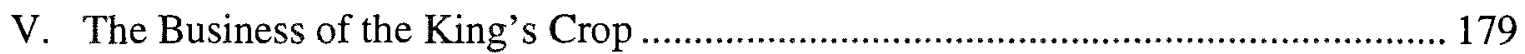

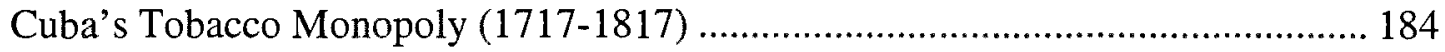

The Tobacco Monopoly's Bureaucratic Structure …............................................. 190

The Operation of the Tobacco Monopoly ........................................................... 212

Cuba's Estanco: A Comparative Perspective and An Analysis of its Effects ....... 225 


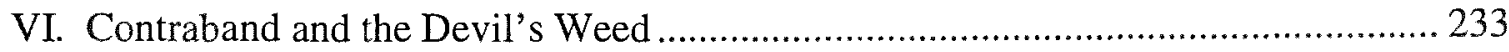

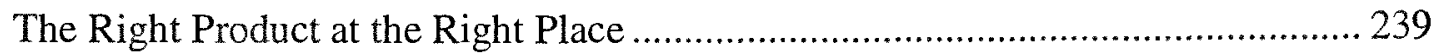

When the Good Guys turn Bad............................................................................ 250

Undermining the Monopoly through More Subtle Forms of Resistance ................ 256

The Lure of the "Devil's Weed"........................................................................... 261

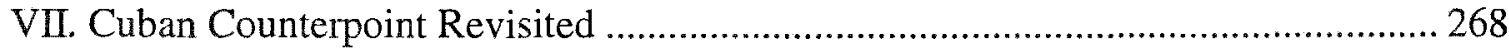

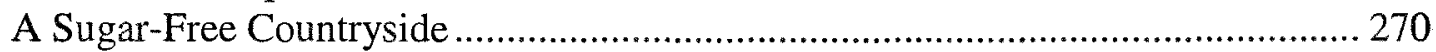

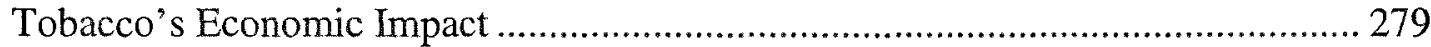

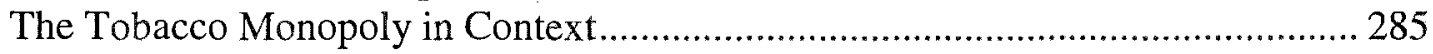

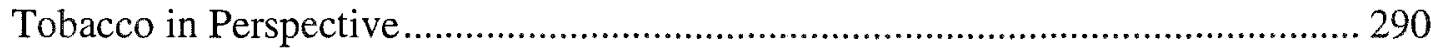

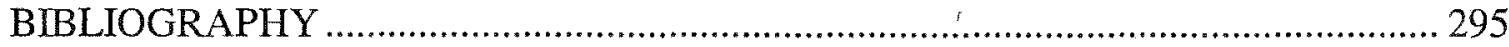

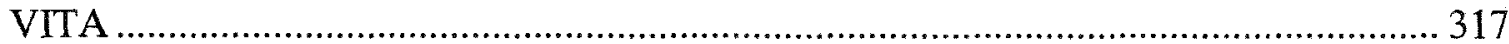




\section{Chapter 1:}

\section{The Cuban Veguero in Myth and History}

Early one evening in 1961, United States President John F. Kennedy asked White House Press Secretary Pierre Salinger to do him a personal favor, deliver 1,000 Petit Upmann cigars to him by the next morning. Around 8 a.m. the following morning, a successful Salinger entered the Oval Office. When Salinger informed Kennedy that he had obtained an additional 200 of the prized Cuban cigars, the young president opened a drawer of the massive, wooden HMS Resolute desk and took out a long piece of paper. Placing the sheet on top of the desk, built from the timbers of an abandoned ship and used by every United States president since it was presented to Rutherford B. Hayes by England's Queen Victoria, Kennedy promptly signed an executive order outlawing all trade with Cuba, including the importation of cigars. ${ }^{1}$ Of all the products available from

1. Pierre Salinger, "Kennedy, Cuba, and Cigars," Cigar Aficionado, Autumn 1992; www.whitehousemuseum.org/furnishings/resolute-desk ; www.jfklibrary.org/ historical+resources/archives/reference+desk/the+presidents+desk. An abandoned ship was purchased, refitted and presented to England's Queen Victoria as a gesture of good will and friendship from the American people. After the vessel's decommission, its timbers were formed into a beautiful piece of furniture that the British queen presented to President Hayes (1877-1881). This same desk was used by Secretary of State John Hay to sign the peace treaty that ended the Spanish-American War (1898-1899). For a detailed history of the U.S. embargo of Cuba, see Charlotte A. Cosner, "The U.S. Embargo of Cuba Under the Clinton Administration: A Historical Review and Projections for Its Future," unpublished master's thesis (Coral Gables, Florida: University of Miami, 1997). 
Cuba on the world market, it was not sugar, perhaps the one today most closely

associated by historians with the island, but tobacco that Kennedy wanted. ${ }^{2}$

Kennedy's association with Cuba went far deeper than just his love of a good

smoke. The events which marked his administration, the failed Bay of Pigs invasion and the Cuban Missile Crisis, set into motion a historiographical change that placed the two once-close nations at odds. ${ }^{3}$ Cuba's new leader Fidel Castro became increasingly closer to the Soviets and toward Communism spurring an influx of works published in the United States that attempted to place the events of 1959 in historical perspective, driven by a need to understand the causes for such a dramatic change in the island's political system and the roots of its radical revolution. As part of this examination, all areas of

2. The historiography of Cuban sugar and its predominant labor form, slavery, is extensive and includes Laird W. Bergad, Cuban Rural Society in the Nineteenth Century: The Social and Economic History of Monoculture in Matanzas (Princeton, New Jersey: Princeton University Press, 1990); Raúl Cepero Bonilla, Azúcar y abolición (Apuntes para una historia crítica del abolicionismo (La Habana: Editorial Cenit, 1948); Félix Goizueta-Mimó, Azúcar amargo cubano: monocultivo y dependencia economica (Madrid: Instituto de Sociologia y Desarrollo del Area Iberica, 1972); Ramiro Guerra y Sánchez, Sugar and Society in the Caribbean: An Economic History of Cuban Agriculture, with a foreword by Sidney W. Mintz, Caribbean Series (New Haven and London: Yale University Press, 1964); Manuel Moreno Fraginals, The Sugarmill: The Socioeconomic Complex of Sugar in Cuba, 1760-1860, translated by Cedric Belfrage (New York: Monthly Review Press, 1976); Robert L. Paquette, Sugar is Made with Blood: The Conspiracy of La Escalera and the Conflict Between Empires Over Slavery in Cuba (Middletown, CT: Wesleyan University Press, 1988) among others.

3. Louis A. Pérez, Jr., On Becoming Cuban: Identity, Nationality, and Culture (Chapel Hill and London: The University of North Carolina Press, 1999) provides a detailed discussion of the interconnected relationship between Cuba and the United States, particularly in terms of culture, examining the "ways that this encounter influenced the context in which Cuban identity and nationality acquired recognizable forms. What Cubans derived from this experience shaped how they came to understand their relations with North Americans, no less than the relations among themselves." Pérez, On Becoming Cuban, 5. 
Cuban history, and issues such as, colonialism, slavery, imperialism, and nationalism were seen not in isolation but "as part of a historical process with antecedents dating to the sixteenth century and with implications reaching to the end of the twentieth century."4 Yet, as Henry Steele Commager argued,

There is bias in the choice of subject, bias in the selection of the material, bias in its organization and presentation, and, inevitably, bias in its interpretation. Consciously, or unconsciously, all historians are biased: they are creatures of their time, their race, their class, their country--creatures, and even prisoners. ${ }^{5}$

Lack of contact with the island and the taboo nature of travel to Cuba, for example, has shaped the U.S. historiography of Cuba only further distorted by the issues of foreign and national politics stirred by Fidel Castro and his Cuban Revolution. ${ }^{6}$ Around the same time, the emergence of Atlantic studies as a field of historical inquiry provided a counterpoint to this political-based scholarship and led to the growth of works which

4 - Louis A. Pérez, Jr., Essays on Cuban History: Historiography and Research (Gainesville: University Press of Florida, 1995), ix.

$5 \cdot$ Robert F. Berkhofer, Jr., Beyond the Great Story: History as Text and Discourse (Cambridge and London: Belknap Press of Harvard University Press, 1995), 140.

6 . For a discussion of the politics inherent in the historiography of Cuba, see Carmelo Mesa-Lago, "Three Decades of Studies on the Cuban Revolution: Progress, Problems, and the Future," in Cuban Studies Since the Revolution, edited by Mark Fernández, with a foreword by Mark Rosenberg (Gainesville, FL: University Press of Florida, 1992), 9-44; Louis A. Pérez, Jr., "Twenty-Five Years of Cuban Historiography: Views from Abroad," Cuban Studies 18 (1988): 87-101; Pérez, Louis A., Jr., Essays on Cuban History; José Luis Rodríguez, "The Antecedents and Theoretical Characteristics of Cubanology," in Cuban Political Economy, edited by Andrew Zimbalist (Boulder, CO: Westview Press, 1988), 22-35. 
compared or examined the interconnectiveness of Atlantic basin colonies and states. ${ }^{7}$

Building on the growing influence of Atlantic studies, scholars recently have begun to document the close economic, political and social ties that linked the former British colonies and Cuba during the late-eighteenth and early-nineteenth centuries. ${ }^{8}$

Cuba's ties to tobacco have a valid historical basis and run so deep that even the name of its capital city is synonymous with cigars. Long used by the island's Amerindian

7. One scholar cites the birth of Atlantic studies as the Johns Hopkins 1967 Atlantic seminar, followed by the creation of its degree program in Atlantic history and culture in 1971. See Eliga H. Gould, "Entangled Histories, Entangled Worlds: The English-Speaking Atlantic as a Spanish Periphery," American Historical Review 112, no. 3 (June 2007): 784. John Thorton in Africa and Africans in the Making of the Atlantic World, 1400-1800, 2nd ed., (Cambridge: Cambridge University Press, 1998), 14, however, credits scholars Fernand Braudel, Pierre Chaunu and Hugette Chaunu with laying the groundwork for Atlantic studies by revising the way in which regional history was created. See Fernand Braudel, La méditerranée et le mond méditerranéen dans les temps de Phillippe II (Paris, 1949); Pierre Chaunu and Hugette Chaunu, Séville et l' Atlantique, 1504-1650, vol. 9 vols. (Paris, 1955-60). The evolution of Atlantic history is addressed in Alan L. Karras and J.R. McNeill, eds., Atlantic American Societies: From Columbus Through Abolition, 1492-1888 (London and New York: Routledge, 1992); Bernard Bailyn, "The Idea of Atlantic History," Itinerario 20 (1996): 19-44; Alison Grames, "Introduction, Definitions, and Historiography: What Is Atlantic History?" $O A H$ Magazine of History 18 (April 2004): 3-7. Works which emphasize the interconnectiveness of the Atlantic world include Jack P. Greene, "Beyond Power: Paradigm Subversion and Reformulation and the Re-Creation of the Early Modern Atlantic World," in Interpreting Early America: Historiographical Essays, Jack P. Green (Charlottesville: University of Virginia Press, 1996), 17-42; David Eltis, "Atlantic History in Global Perspective," Itinerario 23, no. 2 (1999): 41.

8. Sherry Johnson, El Niño's Atlantic World Reprecussions in the Age of Revolution (In progress); James A. Lewis, "Anglo-American Entrepreneurs in Havana: The Background and Significance of the Expulsion of 1784-1785," in The North American Role in the Spanish Imperial Economy, 1760-1819, edited by Jacques A. Barbier and Allan J. Kuethe (Manchester, England: Manchester University Press, 1984), 112-26; Linda K. Salvucci, "Anglo-American Merchants and Strategems for Success in Spanish Imperial Markets, 1783-1807," in The North American Role in the Spanish Imperial Economy, 1760-1819, edited by Jacques A. Barbier, Allan J. Kuethe (Manchester, England: Manchester University Press, 1984), 127-33. 
populations, Europeans first became aware of tobacco during Christopher Columbus's first voyage to the New World. While exploring Cuba's interior between November 2 and 5, 1492, members of Columbus's crew saw the natives smoking the plant. ${ }^{9}$ From this moment on, the plant described as " a special gift conferred upon Cuba"” and the island have become almost synonymous. ${ }^{10}$ Much of the historiography of rural Cuba during the colonial period, however, presents a very different picture, one that emphasizes sugar over other agricultural pursuits. When tobacco is addressed, the historiography is filled with misconceptions, errors, and propaganda. Cuba's colonial tobacco farmers thus remain mysterious, almost mythical, figures misrepresented by scholars in Cuba, and often overlooked by those outside of the island.

One of the reasons for this inaccurate portrait is that Cuban history frequently has served non-historical masters. A particular challenge facing historians, E.J. Hobsbawm noted, was that despite one's attempt to maintain professionalism and impartiality

9 - Eugene Ehrlich, Stuart Berg Flexner, Gorton Carruth, and Joyce M. Hawkins, eds., Oxford American Dictionary (New York: Avon Books, 1980), 401; Fernando Ortiz, Cuban Counterpoint: Tobacco and Sugar, translated by Harriet de Onís, with an introduction by Bronislaw Malinowski, prologue by Herminio Portell Vilá, new introd by Fernando Coronil, reprint, 1947 (Durham: Duke University Press, 1995), 106-10. For use of tobacco by native peoples throughout the Americas, see Francis Robicsek, The Smoking Gods: Tobacco in Maya Art, History, and Religion, with a foreword by Michael D. Coe and Barbara A. Goodnight (Norman: University of Oklahoma Press, 1978); Johannes Wilbert, Tobacco and Shamanism in South America (New Haven, CT: Yale University Press, 1987); Joseph C. Winter, Tobacco Use by Native Americans: Sacred Smoke and Silent Killer (Norman: University of Oklahoma Press, 2000).

\section{Ortiz, Cuban Counterpoint, 8.}


"history is inextricably bound to contemporary politics...."11 As historians in Cuba sought to craft the island's history in the years leading up to and after its independence, an artificial national identity emerged. Emphasizing Cuba's whiteness and rejecting its African influences, Cuba's iconic figure, Liborio, was depicted as "a thin, short, white guajiro (peasant) with sideburns and a mustache."12 The construction of a predominantly white identity "contrasted sharply" with the island's history, yet it mirrored Cuban society where one's's legal color was the primary social dividing line. ${ }^{13}$ Cuba's tobacco farmers, or vegueros, were key players in the continuation of this mythical identity. Writers described the colonial tobacco farmers as proud and independent rural peasants who defied the mighty Spanish crown and fought against the imposition of a tobacco monopoly during the early $1700 \mathrm{~s}$. The lowly white veguero embodied the best traits of

11 - E.J. Hobsbawm, "The Historian Between the Quest for the Universal and the Quest for Identity," in The Social Responsibility of the Historian, edited by François Bédarida (Providence, RI: Berghahn Book, 1994), 55.

12. Aline Helg, Our Rightful Share: The Afro-Cuban Struggle for Equality, 1886-1912 (Chapel Hill: University of North Carolina Press, 1995), 105.

13 . Ibid. For the role of race in late colonial Cuban society, see Verena MartínezAlier, Marriage, Class and Colour in Nineteenth-Century Cuba: A Study of Racial Attitudes and Sexual Values in a Slave Society (Cambridge, England: Cambridge University Press, 1974). Newer works argue that racial attitudes had changed by the latenineteenth century due in part to the armed struggle for independence. See Rebecca J. Scott, "Race, Labor, and Cititzenship in Cuba: A View from the Sugar District of Cienfuegos, 1886-1909," Hispanic American Historical Review 78, no. 4 (1998): $687-$ 728; Ada Ferrer, Insurgent Cuba: Race, Nation, and Revolution, 1868-1898 (Chapel Hill and London: The University of North Carolina Press, 1999). 
the Cuban people, and thus the myths that surround the island's colonial tobacco industry and particularly those who cultivated the plant were not only born, but also perpetuated. ${ }^{14}$

Today's historians of Cuba continue the tradition of earlier commentators and scholars. Stories, impressions, and arguments are repeated without questioning the original sources or the resulting interpretations. As a result, the thesis reiterates that late eighteenth- and early nineteenth-century Cuban tobacco farmers were poor, white, Canary Island men for whom the tobacco monopoly was an annoying governmental institution, first challenged and then later passively tolerated.15 At best, this argument is inaccurate

14 - See Ortiz, Cuban Counterpoint; José Rivero Muñiz, Las tres sediciones de los vegueros en el siglo XVIII (La Habana: Academia de la Historia de Cuba, 1951); José Rivero Muñiz, Tabaco: Su historia en Cuba, vol. 1-2 (Havana: Instituto de Historia, 1964-65); Ramiro Guerra y Sánchez, José M. Pérez Cabrera, Juan J. Remos, and Emeterio S. Santovenia, Historia de la nación cubana, vols. 2-3, (La Habana: Editorial Historia de la Nación Cubana, 1952); Manuel Moreno Fraginals, El ingenio: complejo económico social cubano del azúcar (La Habana: Editorial de Ciencias Sociales, 1978). This phenomenon is not unique to Cuba. "In many historical works the tobacco sector is shrouded in a veil of romanticism. For the authors of these works, the cultivation of tobacco brought out the best qualities of the Dominican people. The tobacco producers were hardworking, honest, and thrifty, and they formed the backbone of Dominican identity. During the Trujillo dictatorship, these ideas were used to forge the image of a robust, white class of cultivators that constituted the core of Dominican national identity, much as the jibaro in Puerto Rico or the guajiro in Cuba did." Michiel Baud, Peasants and Tobacco in the Dominican Republic, 1870-1930 (Knoxville: University of Tennessee Press, 1995), 8.

15 - Efrén Córdova, El trabajo forzoso en Cuba (Un recorrido amargo de la historia) (Miami: Ediciones Universal, 2001), 98; Herbert S. Klein, Slavery in the Americas: A Comparative Study of Virginia and Cuba (Chicago: University of Chicago Press, 1967), 148; Franklin W. Knight, Slave Society in Cuba During the Nineteenth Century (Madison: The University of Wisconsin Press, 1970), 65; Allan J. Kuethe and G. Douglas Inglis, "Absolutism and the Enlightened Reform: Charles III, the Establishment of the Alcabala, and Commercial Reorganization in Cuba," Past and Present: A Journal of Historical Studies 109 (November 1985): 134; Moreno Fraginals, The Sugarmill, 2123; John Robert McNeill, Atlantic Empires of France and Spain: Louisbourg and Havana, 1700-1763 (Chapel Hill: University of North Carolina Press, 1985), 116. 
and, at worst, deliberate propaganda. The study that follows does not suggest, however, that none of the tobacco farmers were poor, white, or Canary Islanders, but instead argues for a more complex picture of those involved in the cultivation of tobacco during this time.

This work is both a micro and macro level study of rural life in colonial Cuba and the interconnected relationships among society, agricultural production, state control, and the island's economic development. By placing Cuba's vegueros at the forefront of this social history, this study will revisit and offer alternatives to two prevailing historiographical views of rural Cuba during the mid- to late eighteenth century. The first argues for the primacy of sugar over other agricultural crops, a view that has shaped decades of scholarship. The second maintains that the Cuban tobacco farmer was poor and white and employed free labor rather than slaves in the production of their crop. In tracing the role of tobacco growers in colonial Cuba, this study also examines the topic from a comparative geographical perspective, placing Cuba in a larger Atlantic world context by building upon the pioneering work by Herbert S. Klein that compared slavery in Cuba and Virginia. Tobacco was a primary focus of agricultural activity in both colonies, yet the labor force that tended the plant varied between the two areas, Klein argued. Virginia was engaged in large-scale plantation tobacco cultivation based upon slave labor, particularly in the early days of the colony, while Cuban tobacco production required little slave participation, Klein contended. ${ }^{16}$ Although the vehicle, slavery, used by Klein to examine Cuba and Virginia may have been inaccurate, there were many

$16 \cdot$ Klein, Slavery in the Americas. 
similarities between the two particularly in the methods used to cultivate tobacco. This study, however, moves beyond the comparisons made by Klein to argue for a more complex picture of those who tended tobacco. Lastly, this study will examine the issue of contraband so eloquently portrayed by some scholars as not only undermining the official tobacco monopoly, but also Spain's hold on the island's commerce.

Research conducted in the Archivo General de Indias in Seville, Spain, as well as Cuba's Archivo Nacional de Cuba in Havana, and the Archivo Histórico Provincial de Pinar del Río allows the construction of a vastly different picture of the vegueros and their response to governmental control of their industry. Far from being a homogeneous body, Cuba's tobacco farmers included all segments of colonial society. Documents generated at the local, national, and imperial levels demonstrate that those who worked in, and/or owned tobacco fields were a varied and diverse group including, but not limited to, men of higher social standing such as those with noble titles, retired members of the military, the clergy, foreigners, women, free blacks, and slaves. Although Cuba did not have the massive tobacco plantations worked by hundreds of slaves as was the case in Virginia, some Cuban slaves cared for their owner's tobacco, as well as growing it themselves. After the initial rebellions when the monopoly was created in 1717, Cuba's vegueros did not assent to the royal tobacco monopoly. The lack of specific, organized opposition to the monopoly along the lines of the earlier revolts did not mean that the island's tobacco farmers passively complied with the government's restrictions on their crop. Instead, the vegueros continued to challenge it, although they employed less violent 
means, finding innumerable ways to circumvent one of the most prolific Bourbon moneymaking schemes. ${ }^{17}$

\section{The Early History of Cuba's Most Important "Weed"}

Tobacco quickly reached the European continent after it was first encountered by Europeans. By the mid-1500s, tobacco was known in Europe's port cities and North Africa. All forms of the product, especially smoking and snuff, rapidly gained in popularity. ${ }^{18}$ Increasing European demand for tobacco led more and more overseas colonies to direct their energies toward its cultivation. As early as 1618 , Virginia exported 20,000 pounds of the leaf to England. ${ }^{19}$ Less than ten years later, this figure increased to around 500,000 pounds, and by the end of the century the colony averaged 22 million pounds of leaf per year. Hoping to repeat Virginia's success with the plant,

17 . For more on passive resistance, see James C. Scott, Weapons of the Weak: Everyday Forms of Peasant Resistance (New Haven: Yale University Press, 1985); James C. Scott, Domination and the Arts of Resistance: Hidden Transcripts (New Haven: Yale University Press, 1990).

18 - For the spread of tobacco throughout the world, see John Crawford, "On the History and Consumption of Tobacco," Journal of the Statistical Society of London 16, no. 1 (March 1853): 45-52; Reynaldo González, "Los Primeros Pasos del Tabaco," Casa de las Américas 27, no. 158 (1986): 123-31; Jordan Goodman, Tobacco in History: The Cultures of Dependence (London: Routledge, 1993).

19 - W. F. Axton, Tobacco and Kentucky (Lexington: The University Press of Kentucky, 1975), 25. Axton credits Cuba for Virginia's success with tobacco cultivation, arguing that Nicotiana tabacum seed was smuggled out of Cuba and brought to the British colony to replace the inferior local tobacco, Nicotiana rusticum, grown by Virginia's Native Americans. 
the British founded colonies at St. Kitts, Barbados, Nevis, Antigua, Montserrat, Tobago, and St. Lucia dedicated to growing tobacco.20

Under the Spanish imperial economy, Cuba was the most significant player in the tobacco trade, so much so that by the early eighteenth-century tobacco was one of the island's primary export items. ${ }^{21}$ Realizing the potential for profit, the Spanish crown imposed an official monopoly on Cuban tobacco in 1717 . The government paid the farmers in advance at fixed prices that closely matched those received before the monopoly was created. The vegueros, however, resented state control of their industry and opposed Spain's plan to purchase Cuban tobacco at low prices only to sell it on the European market at inflated levels. ${ }^{22}$ At a Havana council session on August 6, 1717, the farmers' request to end the monopoly was denied. Seventeen vegueros protested, arguing that they were loyal subjects of the crown, and noted their repeated defense of the island as militia members. Many tobacco farmers were very poor, they contended, and did not even own the land they worked. Surely the Cabildo (town council) would take these factors into consideration, the farmers pleaded. ${ }^{23}$ Despite their protests, the monopoly remained in place.

$20 \cdot$ Klein, Slavery in the Americas, 166; K.G. Davies, The North Atlantic World in the Seventeenth Century (Minneapolis: University of Minnesota Press, 1974), 39.

$21 \cdot$ McNeill, Atlantic Empires of France and Spain, 115.

22. José Rivero Muñiz, Tabaco: Su historia en Cuba, vol. 1 (La Habana: Instituto de Historia, 1964), 90.

23 - Rivero Muñiz, Las tres sediciones, 27. 
Over the next several weeks, public outcry over the tobacco monopoly increased. Armed groups of Cuban vegueros gathered at Jesús del Monte south of Havana and marched northward, encircling the capital and preventing reinforcements from reaching the governor and his soldiers. Renouncing his position as governor of Cuba, Vicente Raja returned to Spain, marking the "first violent expulsion of a Captain General" in Cuban colonial history. ${ }^{24}$ Gregorio Guazo Calderón became the new governor, and authorities reinstated the tobacco monopoly after making some minor concessions to the farmers. ${ }^{25}$

Tensions over the monopoly remained between the government and Cuba's tobacco farmers, and in June of 1720 , violence again erupted. More than 200 tobacco growers revolted, and for two weeks they burned tobacco houses and crops belonging to nine residents around Santiago de las Vegas. Government officials responded by detaining the individuals believed to be the principal leaders of the movement. The vegueros learned that the capital's defenses were strengthened and decided against directly attacking Havana, opting instead to lay siege to the city. As in 1717 , the clergy tried to mediate, but the farmers initially refused to listen. ${ }^{26}$

Over the next two years, Cuba enjoyed relative calm, although tobacco farmers' complaints about payments-in-kind and on-terms increased tensions between the growers and the island's administration. The poorest farmers asked to sell their crop at slightly

24 . Ibid., 33, 38 .

25 · Rivero Muñiz, Tabaco, vol. 1, 105-11. 
higher prices directly to the urban cigar and cigarette factories. Other, more affluent vegueros demanded the governor's expulsion from the island. When the tobacco growers' demands went unanswered, they threatened that they would not plant tobacco until prices increased, and to burn all snuff stored in Havana including any found in the royal stores. ${ }^{27}$

The third and final veguero insurrection took place in 1723 . Unlike previous revolts, the tobacco farmers split along socioeconomic lines with some refusing to join, arguing that their continued planting of tobacco was their only way of supporting themselves and their families. In early February 1723, a group of approximately 300 farmers converged on San Miguel del Padrón and ripped up tobacco plants, first from their own fields, and later in nearby plots. Many vegueros agreed not to plant the crop for two years, choosing to wait instead for higher prices. Governor Guazo Calderón warned the tobacco growers that the state intended to punish dissenters with death. ${ }^{28}$ The farmers remained undeterred. Residents of San Felipe and Bejucal sought the governor's help, and he responded by sending soldiers to nearby Santiago de las Vegas. On the morning of February 20, soldiers prepared to face off against a reported six hundred vegueros. In the resulting skirmish, one soldier was wounded, and another was thrown from his mount after the animal's reins were cut. Many vegueros were wounded, and government forces captured eleven men, forcing the remaining farmers to retreat. The next evening, 100

26. Rivero Muñiz, Las tres sediciones, 59-63.

$27 \cdot$ Ibid., 67, 69-71. 
armed men gathered in Guanabacoa, located just to the east of the capital, intent on rescuing the imprisoned farmers. A local priest was able to calm the group, which quietly dispersed the following morning. The governor, fearful of more violence, resolved to teach the rebels a lesson. The eleven vegueros were executed and, as a warning against further revolts, their bodies hung in trees along the roadside for forty hours while soldiers stood guard. The corpses were finally taken down after the governor acquiesced to pleas made by Bishop Gerónimo Valdés, the Conde de Casa-Bayona, and others. ${ }^{29}$

These violent reactions by the Cuban vegueros to what they felt were unfair governmental controls on their industry were not without historical precedent. Popular uprisings, frequently the first of their kind, against colonial authority in the New World often were a response to measures taken against tobacco. Some historians cite the displeasure of Virginia's tobacco growers with colonial taxation, particularly the tax on tobacco, as a mitigating factor in Bacon's Rebellion (1676). ${ }^{30}$ Just six years later, control

28 - Rivero Muñiz, Tabaco, vol. 1, 119; Rivero Muñiz, Las tres sediciones, 71-75.

29 - Rivero Muñiz, Tabaco, vol.1, 122-4; Rivero Muñiz, Las tres sediciones, 8193; Leví Marrero, Del monopolio hacia la libertad comercial (1701-1763)(II), vol. 7 of Cuba: economía y sociedad (Madrid: Editorial Playor, 1978), 45-54.

30 - Charles M. Andrews, ed., Narratives of the Insurrections, 1675-1690, reprint, 1915 (New York: Barnes and Noble, 1967), 11; Harry Firestone, ed., Bacon's Rebellion: The Contemporary News Sheets (Charlottesville: University of Virginia Press, 1956), 29; William Brantley Aycock, "Tobacco Regulation in Colonial Virginia," M.A. thesis (Chapel Hill, NC: University of North Carolina, 1937), 71-73; Davies, The North Atlantic World, 226. Aycock contends, “...to interpret the causes which led to Bacon's Rebellion in terms of tobacco would not be varying a great deal from the actual situation." Aycock, "Tobacco Regulation in Colonial Virginia," 72. Andrews describes Bacon's Rebellion as "the first popular uprising in colonial America." Andrews, Charles M., Narratives of the Insurrections, 1675-1690, 11. 
of tobacco again prompted Virginians to respond with violence. Challenging measures implemented in the 1680 s to ensure a stable and high price for Virginia tobacco, some farmers set out on a tobacco-cutting riot in May 1682. The revolt began in Gloucester County and spread to New Kent, Middlesex, and York Counties. As was later the case in Cuba, farmers first destroyed their own crops, then moved on to neighboring farms. An estimated 10,000 hogsheads of tobacco were destroyed in Gloucester and New Kent Counties alone by the end of the month. ${ }^{31}$ This would not be the last time, however, that Virginia tobacco farmers resorted to violence.

In response to the Virginia Inspection Act of 1730, which required that all tobacco be subject to inspection by public officials, tobacco growers again rebelled and refused to bring in their tobacco. Four warehouses in Virginia's Prince William, King George, Northumberland, and Lancaster Counties were burned in March 1732. The violence spread to Maryland where wealthy planters joined the uprisings. Although laws were on the books in Virginia that made destruction of a tobacco warehouse an offense punishable by death, colonial officials were reluctant to make martyrs out of those responsible, and feared reprisals if such action was taken. ${ }^{32}$

Virginia's tobacco farmers, moreover, were not the only ones who responded with violence when confronted with perceived excessive controls on tobacco. Opposition to a

31 - Theodore Saloutos, "Efforts at Crop Control in Seventeenth Century America," Journal of Southern History 12, no. 1 (February 1946): 62-65; Aycock, "Tobacco Regulation in Colonial Virginia," 74-82.

32. Alan Kulikoff, Tobacco and Slaves: The Development of Southern Cultures in the Chesapeake, 1680-1800 (Chapel Hill: University of North Carolina Press, 1986), 109-12. 
royal monopoly on tobacco triggered at least three separate South American revolts against the Spanish crown during the latter-half of the eighteenth-century alone. Chileans rebelled against official controls on tobacco in 1776, and Venezuelan growers in Grita reacted similarly only three years later. New Granada's 1781 comunero revolt also had its roots as an opposition to the tobacco monopoly. ${ }^{33}$ As had been the case in Cuba, "the treachery and deceit with which the comuneros were put down served to fortify in the locality the conception of the tobacco monopoly as the epitome of Spanish tyranny." 34

\section{The Myth of the Cuban Veguero: Poor, White, and Isleño}

The dark nature of tobacco versus sugar's whiteness is a central feature of the juxtaposition found in Fernando Ortiz's classic 1940 treatise, Contrapunto cubano, published in English seven years later as Cuban Counterpoint. Ortiz describes tobacco as "dark, ranging from black to mulatto...Tobacco does not change its color; it is born dark and dies the color of its race." 35 Ortiz emphasizes the differences between the two plants including the respective social consequences of each, yet he does not extend his description of tobacco as black or mulatto to those who labored in the island's tobacco

33 · Marcelo Carmagnani, "La oposición a los tributos en la segunda mitad del siglo XVIII," Revista chilena de historia y geografia 129 (1961): 161-68; John P. Harrison, "The Evolution of the Colombian Tobacco Trade, to 1875," Hispanic American Historical Review 32, no. 2 (May 1952): 166. Carmagnai notes that the 1776 revolt was one of the first by Chilean creoles against Spain. Similarly, Harrison describes the comunero revolt as "the only spontaneous uprising of any size in the colonial history of New Granada." Harrison, 166.

34 - Harrison, "Evolution of the Colombian Tobacco Trade," 166. 
fields. Instead, he repeatedly argues that whites exclusively produced Cuba's tobacco. ${ }^{36}$

Ortiz, however, is not the only Cuba-based scholar to make this assertion. Ramiro Guerra y Sánchez and Emeterio S. Santovenia insist that the veguero was Cuban-born, a Spaniard, or a Canary Islander. ${ }^{37}$ Another scholar even goes so far as to argue, "The skill, care and experience necessary for tobacco growing did not allow slave labor."38 Historians working outside of the island also reiterate this same thesis. Stanley M. Elkins and Sidney Mintz contend that there was no connection between slavery and tobacco, while Philip D. Curtin similarly argues for an European influence in Cuban tobacco cultivation. ${ }^{39}$ In the Cuban historiographical pantheon, the vegueros exhibited all of the necessary characteristics of the classic underdog. As small-scale farmers, they grew limited amounts of tobacco. The historiography contends that they were so poor they

$35 \cdot$ Ortiz, Cuban Counterpoint, 9.

$36 \cdot$ Ibid., $57,59,82,87$.

37 - Ramiro Guerra y Sánchez, José M. Pérez Cabrera, Juan J. Remos, and Emeterio S. Santovenia, Ilustración libertad de comercio (desde 1790 hasta 1837), vol. 3 of Historia de la nación cubana (La Habana: Editorial Historia de la Nacion Cubana, 1952), 50, 52-53; Emeterio S. Santovenia, Pinar del Río (Mexico: Fondo de Cultura Economica, 1946), 91.

38 - Gaspar Jorge García Galló, Biografía del tabaco habano (La Habana: Universidad Central de Las Villas, Departamento de Relaciones Culturales, 1959), 39.

39. Stanley M. Elkins, Slavery: A Problem in American Institutional and Intellectual Life, 2d ed. (Chicago: University of Chicago Press, 1968), 37; Sidney W. Mintz, foreward to Sugar and Society in the Caribbean: An Economic History of Cuban Agriculture by Ramiro Guerra y Sánchez, (New Haven and London: Yale University Press, 1964), xxvii; Philip D. Curtin, The Rise and Fall of the Plantation Complex: Essays in Atlantic History, 2nd ed. (Cambridge: Cambridge University Press, 1998), 199. 
were barely able to sustain their families, much less afford to buy slaves to work in the fields.

On occasion, scholars concede the possibility of slave laborers in the island's tobacco fields, but insist that their role was minimal. The use of slaves on Cuba's tobacco vegas was "scarce," argue both Julio Le Riverend and Efrén Córdova, while a similar argument is made by Robin Blackburn who stresses that Cuba's tobacco farmers "owned few or no slaves. ${ }^{40}$ Although published nearly twenty years apart, studies by Herbert Klein and John Robert McNeill acknowledge a stronger slave presence than most works. Klein concedes that "a large number of slaves were employed in the cultivation of tobacco," but notes that unlike sugar they were scattered throughout the countryside with a small number of slaves working on many different vegas, a thesis also held by McNeill. ${ }^{41}$ The primary thrust of both Klein's and McNeill's argument, however, remains that tobacco was predominantly produced by whites, giving tobacco what Klein calls a "sharply democratic flavor." 42 Conversely, Joan Casanovas does not make such qualifying assertions, stating that slaves worked at every stage of tobacco production,

40. Julio le Riverend, Historia económica de Cuba (Barcelona: Ediciones Ariel, 1972), 80; Córdova, El trabajo forzoso, 98; Robin Blackburn, The Making of New World Slavery: From the Baroque to the Modern 1492-1800 (London and New York: Verso, 1997), 495, 498. Blackburn cites Richard Pares, War and Trade in the West Indies, 1739. 1763 (Oxford: The Clarendon Press, 1936) and Heinrich Friedlander, Historia economica de Cuba, vol. 1, Havana: Editorial de Ciencias Sociales, 1978, 92 as sources for his claims. Spain, 43-44, 116.

$41 \cdot$ Klein, Slavery in the Americas, 148; McNeill, Atlantic Empires of France and 42. Klein, Slavery in the Americas, 148. 
although admittedly his study addresses urban workers, predominantly tobacco rollers rather than those who worked in the fields. ${ }^{43}$

One of the central features of Cuban Counterpoint's polarity between tobacco and sugar cultivation is the argument that whites, not blacks, were the primary and almost exclusive growers of tobacco. Ortiz and others contend that the role of Africans, particularly slaves, in tobacco was nonexistent or extremely limited. ${ }^{44}$ Recent scholarship, however, has begun to move past this narrow historiographical view to consider the presence of Africans in Cuba's tobacco fields. ${ }^{45}$ While this shift is welcome, no real attempt to date has been made to detail the role of Africans, both slave and free, in growing tobacco. This study utilizes documents including tazmias, as well as correspondence between local officials, Havana-based authorities, and bureaucrats in Spain to pose a detailed challenge to the existing historiography. The numerous annual accounting ledgers demonstrate conclusively that both slaves and free blacks grew tobacco in all parts of the island. Correspondence found in Cuban and Spanish archives similarly confirm that from the 1750 s onward residents and government officials alike sought slaves for use in the tobacco fields, making the case for the long-standing use of slave labor in the island's tobacco industry.

43 . Joan Casanovas, Bread, or Bullets! Urban Labor and Spanish Colonialism in Cuba, 1850-1898 (Pittsburgh: University of Pittsburgh Press, 1998), 22.

44 . Some of the scholars which continue this thesis include Ortiz, Cuban Counterpoint, 57, 59-60; Elkins, Slavery, 37; Riverend, Historia económica de Cuba, 126. For a more comprehensive discussion of the historiography, see Chapter 1.

45 - Casanovas, Bread, or Bullets! 22; Córdova, El trabajo forzoso, 98. 
In the Cuban historiographical pantheon, the vegueros exhibited all of the necessary characteristics of the classic underdog. As small-scale farmers, they grew limited amounts of tobacco. The historiography contends that they were so poor they were barely able to sustain their families, much less afford to buy slaves to work in the fields. This study will demonstrate that the veguero population was far more diverse and complex than previously asserted in the historiography. Tobacco planting was not just a "pursuit of the lower orders" as the Marqués de Cárdenas de Monte-Hermoso stated in the nineteenth century. ${ }^{46}$ In reality, however, Cuba's colonial vegueros were not restricted to one group of individuals. Instead, the ranks of those who labored in the island's tobacco fields, as well as those who encouraged the cultivation of tobacco as vega owners included virtually all sectors of society. Current or former members of the military, priests, those with noble titles, and women contributed to the island's tobacco industry. It is this complexity that makes the veguero's role in eighteenth-and nineteenth-century Cuban society that much more interesting and vital. In addition, people of color, both free and slaves, worked alongside their white counterparts in the island's tobacco fields from 1763 to 1817 . Furthermore, slaves working in the fields occasionally earned enough money to purchase their freedom demonstrating that tobacco offered an avenue for Cuba's people of color to integrate themselves into the general population in terms of social and economic opportunities. The presence and importance of people of color in tobacco production gives a new understanding of the labor force that brought this valuable crop to market.

46. Moreno Fraginals, The Sugarmill, 21-22. 
While scholars might disagree on the composition of this rural population, all agree that Cuba's colonial tobacco farmers were small-scale agriculturists. ${ }^{47}$ Some see the monopoly as responsible for this trend. Manuel Moreno Fraginals asserts that the tobacco monopoly itself encouraged small farmers and prevented the growth of an upper class based on tobacco. ${ }^{48}$ Allan J. Kuethe and G. Douglas Inglis agree, arguing that the monopoly's practices of arbitrarily fixing prices and setting quotas meant that tobacco had become the "small man's concern" by 1763.49 The historiographical view that Cuba's colonial tobacco farmers were poor, small-scale agriculturists may have had its roots in the observations of eighteenth- and nineteenth-century contemporaries. One of the strongest critics of the monopoly, Francisco Arango y Parreño argued that tobacco required "care, but not capital" and thus was an ideal pursuit for those that were poor. ${ }^{50}$ He viewed tobacco planters as "miserable pejugaleros (outservants), and prided himself on the fact that his rich compatriots neither owed their fortunes to tobacco, nor crossed

47 - Riverend, Historia económica de Cuba, 80; Guerra y Sánchez, Pérez Cabrera, Remos, and Santovenia, Ilustración libertad de comercio (desde 1790 hasta 1837), 10; Córdova, El trabajo forzoso, 98; Klein, Slavery in the Americas, 148; Knight, Slave Society in Cuba, 64.

48 - Moreno Fraginals, The Sugarmill, 22.

49. Kuethe and Inglis, "Absolutism and the Enlightened Reform," 134. Kuethe repeats this argument in Allan J. Kuethe, Cuba, 1753-1815: Crown, Military, and Society (Knoxville: The University of Tennessee Press, 1986), 53.

50 - Francisco Arango y Parreño, De la Factoría a la colonia (La Habana: Secretaria de Educación, Dirreción de Cultura, 1936), 54-56. 
the threshold of the Factoría."51 While tobacco growing may not have taken place on the same scale as sugar, for example, several tobacco farmers had sizable operations covering dozens of acres. In addition, the number of noble families who owned vegas and were involved in other aspects of the tobacco industry indicates that both the Marqués and Arango's arguments were incorrect, or misleading at best.

The value of this study runs far deeper than simply reclassifying an important group of agricultural participants. The existing historiography that emphasizes that the vegueros were poor, marginalized members of society implies that the tobacco farmers simply were unable to resist the all-powerful tobacco monopoly after the initial three rebellions of the late 1710 s and early 1720 s. Because tobacco farmers were not a homogeneous group for whom tobacco cultivation, even under strict governmental control, was their only means of financial stability, compliance with the monopoly was not a matter of economic life-and-death. Moreover, the absence of organized riots from 1763 to 1817 did not mean that the monopoly's regulations were obeyed by the Cuban vegueros. Other methods of undermining the tobacco monopoly included contraband, improper packing of one's tobacco in order to defraud the government, and other means of passive resistance. By improving our understanding of these important colonial actors,

51 . Moreno Fraginals, The Sugarmill, 21. Arango's bitterest enemy was former intendant Rafael Gómez Roubaud, the superintendant of the Royal Tobacco Monopoly. The feud between the two began when Arango served as the assessor of the monopoly and Gómez Roubaud was his superior. Kuethe, $C u b a, 1753-1815,158$; José Rivero Muñiz, Tabaco: Su historia en Cuba, vol. 2, Desde los inicios de la Segunad Factoría de Tabacos de la Habana hasta mediados del siglo XX (La Habana: Instituto de Historia, 1965), 201-05; Francisco J. Ponte Domínguez, La junta de la Habana en 1808 (Antecedentes para la historia de la autonomía colonial en Cuba) (Havana: Editorial Guerrero, 1947), 67. 
this study also undermines the thesis that the Bourbon Reforms in general, and the reimplementation of the tobacco monopoly in particular, were unavoidable and inevitable reforms in which the Cuban people were helpless bystanders, forced into compliance since no other option was available to them.

\section{A New, Sugar-Free Approach to Cuban History}

The cultivation and curing of tobacco was far from a simple task. "The tobacco farmer, guided simply by the results of years of experience, passed down from his ancestors, knows without being able to explain it, the means to increase or decrease the strength or smoothness of tobacco," a contemporary observer noted. ${ }^{52}$ Chapter 2, "From the Field to the Real Factoría," expands the body of work on Atlantic studies building upon the ground work laid by Herbert S. Klein in his seminal study of Cuba and Virginia. Tobacco cultivation is described from the preparation of the land used for both the seed bed and the fields, to the final stages when it is harvested and cured. After the plant was cured in barns, the farmer packed and presented the tobacco at the royal monopoly's annual purchasing fairs, a process also detailed in this chapter. Threats to the vegueros' livelihood such as the potential loss of their crop from pests, diseases, natural disasters, and other forces beyond their control were a constant concern for the farmers, and will be examined. As this chapter details the planting and growing process, taking tobacco from the field to the royal monopoly's warehouse in Havana, it also compares the methods

52 . Ramón de la Sagra, Historia fisica, politica y natural de la isla de Cuba (Paris: A. Bertrand, 1839), 284. 
utilized by Cuban vegueros to those of tobacco farmers in Virginia and other parts of the world, demonstrating yet again the interconnectiveness of this region as knowledge was passed both north and south despite political and imperial boundaries.

Chapter 3, "Tobacco's Chosen People," establishes the identity of Cuba's vegueros from 1763 to 1817 . Was the typical tobacco farmer a Canary Islander? Were they poor? What types of labor were used in the production of tobacco? Answers to these questions challenge the prevailing image of the colonial Cuban veguero, presenting a very different view of the types of people directly engaged in or sponsoring tobacco cultivation Tazmias, the accounting documents that recorded the amount of tobacco grown, allow modern scholars to reconstruct a vital aspect of colonial Cuba's tobacco economy by identifying and describing those who were involved in its cultivation. Cuban officials used these documents, abundant in number, to keep track of who grew tobacco, the number of people involved in other aspects of its production, and the amount of tobacco grown. Every year in the areas where tobacco was grown, the capitán de partido or other another local official collected the necessary information and passed it on to officials in Havana, usually the captain general. Combined with the resguardo, the enforcement branch of the monopoly discussed in greater detail in a subsequent chapter, these accounting sheets were another mechanism used by the government to ensure that all tobacco destined for the Real Factoría indeed was delivered. ${ }^{53}$

53. Tazmias were in use as early as the 1750 s. Francisco Cagigal de la Vega to Captain General, 12 November 1750, Santiago de Cuba, orden 158, legajo 5, Correspondencia de los Capitanes Generales (hereafter CG), Archivo Nacional de Cuba, Havana, Cuba (hereafter ANC); Alonso Arcos y Moreno to Francisco Cagigal de la Vega, 27 March 1752, Santiago de Cuba, orden 74, legajo 6, CG, ANC; Francisco 
The tazmias were extremely formulaic documents, following almost the same pattern and wording throughout this period. The first column contained the name or names of those responsible for the vega, usually listing them under the heading of veguero, owner (dueño), or renter (arrendatario). The number of vegas operated by this individual sometimes was also included, followed by the total number of individuals working the farm (operarios) with the document usually noting that this figure included the owner. Of primary interest to the royal monopoly was the amount of tobacco on each vega. These production figures were variously described in terms of the number of plants, or in established packaged quantities once it was harvested and cured. ${ }^{54}$ This amount was expressed in cujes (sticks), manojos (bundles), or arrobas (approximately 25 pounds), with cuje being the most common measurement. 55

Cagigal de la Vega to unknown, 16 March 1756, orden 164, legajo 7, CG, ANC. Most tazmias used in this study date from 1768 to 1783 . There are several references to tazmias after 1783 found in correspondence, but only two actual tazmia documents were found in the Spanish and Cuban archive legajos consulted. See Manuel Rodriguez to Don Juan de Mecolaeta, 18 October 1798, number 7, legajo 1003, Intendente General de Hacienda (hereafter IGH), ANC; Juan Gregorio Nuñez to Superintendente Director General, Palacios, 20 October 1809, legajo 1060, IGH, ANC; "Tazmia, Partidos of Rio de Agabama, Rio de Ay, Caracucey, Yguanojo, Animado, and Caunado," 7 June 1789, legajo 1313, PC, AGI; "Autos sobre el mal uso que hacen los vegueros de Chambas y Tatibunico de sus cosechas de tabaco," San Juan de Remedios, 22 November 1798, number 7 , legajo 1003, IGH, ANC.

54 . For the type of information to be included in a tazmia see Francisco Cagigal de la Vega to Alonso de Arcos y Moreno, 7 September 1750, Havana, orden 157, legajo 5, $\mathrm{CG}, \mathrm{ANC}$.

55 - A cuje is defined as "a slender wooden pole or giantreed, on which the cut or strung tobacco is placed for drying. The quantity of tobacco hung on one of these poles...," while a manojo is a bundle of tobacco made up of four gavillas (hands) which vary in the number of leaves depending on the type that are tied together. José E. Perdomo, Léxico tabacalero cubano, reprint, 1940 (Miami: Ediciones Universal, 1998), 
Created merely to keep track of the amount of tobacco grown, the tazmias were not intended to serve as an individual census of Cuba's tobacco growers. Closer inspection of the tazmias reveal details about the race, social status, gender, and occupation of these important agricultural producers. Occasionally clues to the nationality or ancestral origins of these farmers are also provided through descriptions such as "el isleño," "el español (the Spaniard), "el Portugues" (the Portuguese), el gallego" (the Galician), or even "el ingles" (the Englishman). ${ }^{56}$ The presence of both free and enslaved Africans working in tobacco fields, moreover, was not an isolated phenomenon, but one that occurred throughout Cuba, even in Pinar del Río, the region most associated with tobacco and the myth of the veguero. Chapter 4, "A View Down Tobacco Road: A Case Study of Pinar del Río," argues that tobacco cultivation and a guaranteed market gave blacks the economic freedom that resulted from the fruits of their own labor, but also provided people of color more than just an improved economic position in the island's society. Documents found in Pinar del Río's provincial archives suggest that tobacco cultivation offered enslaved workers the chance to move toward the physical liberation from slavery itself. Some emancipated slaves appear to have earned

$182,191,204$. An arroba is equivalent to 25.35 pounds or 11.5 kilograms. Guerra y Sánchez, Sugar and Society in the Caribbean, 42.

56 - Joaquin de Sola, "Tazmia ...Puerto del Príncipe," 25 May 1770, Puerto Príncipe, legajo 1085, Papeles Procedentes de Cuba (hereafter PC), Archivo General de Indias, Seville, Spain (hereafter AGI); Ramón José Rodriguez, "Tazmia de los Tavacos de los Partidos de Naranjal, Estancias, y San Augustín s Respectiva a la cosecha del presente año de 1770," 15 May 1770, Matanzas, legajo 1090, PC, AGI; José de Aguilar y Blanco, "Tazmia qe manifiesta los Tavacos sembrados," 20 March 1782, Sancti Spiritus, PC 1313, AGI, Seville, Spain 
enough money to purchase their freedom from their work in the area's tobacco fields, and in light of these new findings, the historiography furthered by Ortiz and others demands reconsideration.

"The Business of the King's Crop," Chapter 5 of this study, briefly examines tobacco's popularity and details why European states such as Spain, England, and France all instituted royal monopolies as part of their attempt to garner a portion of tobacco's profits for themselves as its use spread. As was the case with other Bourbon Reforms, Cuba proved to be the testing ground for the tobacco monopoly instituted on the island in 1717. The bureaucratic organization of Cuba's Real Factoria de Tabacos (Royal Tobacco Monopoly) is detailed from the highest ranking officials down to the lowly muleteer responsible for transporting tobacco to the royal warehouse in Havana. This chapter also documents the ways in which the estanco (monopoly) controlled the tobacco industry by determining if new vegas could be established, as well as the varying prices paid to vegueros in different locations for the same quality-grade tobacco. The Cuban tobacco monopoly is analyzed to determine if it was a success, both in terms of meeting its stated goals, and as a profit-making endeavor.

Chapter 6, "Contraband and the Devil's Weed," reveals the degree to which contraband proved a problem for the Real Factoria de Tabacos as well as the crown, and demonstrates just how pervasive was the contraband trade. Forms of contraband included hiding tobacco, and offering it for sale to unofficial buyers including privateers and pirates. Those involved in this illegal activity included not only the vegueros, but also others in the industry such as the arrieros (muleteers) charged with taking tobacco from 
the interior of the island to the monopoly in Havana. This illegal activity not only undermined the official tobacco monopoly, but also Spain's họld on the island's commerce. While contraband is difficult to prove or quantify, the numerous reports sent from Spain and from the captain general in Havana to local officials objecting to the activities of smugglers working in concert with residents are powerful testimony to the extent of the problem and the crown's futile efforts to stop the illegal trade. As early as the 1750s, Spanish officials decried the contraband trade in tobacco, ordering farmers to deliver their entire product to the royal monopoly houses and prohibiting the sale of tobacco to individuals. ${ }^{57}$ In just one year alone, periodic sweeps caught respectable citizens, commoners, muleteers, and even local political officials in the snare. ${ }^{58}$ Contraband tobacco could be hidden anywhere, with monopoly representatives recovering tobacco on roads leading to the capital, inside Havana itself, on farms and

57. Juan Ignacio Urriza to Diego José Navarro, 23 August 1779, Havana, legajo 1238, PC, AGI; Diego José Navarro to Juan Ignacio Urriza, 6 August 1779, Havana, legajo 1238, PC, AGI; Juan de Aguilar to Rafael Gómez Roubaud, 5 October 1808, Havana, expediente 12, legajo 96, IGH, ANC; Bartolome Castellanos to Administrador Real Factoria de Tabacos, 12 April 1800, Havana, expediente 1, legajo 898, IGH, ANC; Juan Ignacio Urizza to Diego José Navarro, 4 October 1779, Havana, legajo 1238, PC, AGI; Juan Ignacio Urriza to Juan Miguel Cagigal y Monserrate, 19 July 1782, expediente 455, legajo 1308, PC, AGI; Lorenzo de Escobál to Marqués de la Torre, 3 November 1773, Matanzas, legajo 1181, PC, AGI.

58 - Juan Ignacio Urriza to Diego José Navarro, 13 November 1779, Havana, legajo 1238, PC, AGI; Juan Ignacio de Urriza to Diego José Navarro, 22 September 1779, legajo 1238, PC, AGI; Juan Ignacio de Urriza to Diego José Navarro, 4 October 1779, legajo 1238, PC, AGI; Diego José Navarro to Juan Ignacio Urriza, 2 October 1779, Havana, legajo 1238, PC, AGI. 
sugar estates, homes and boats. The drive to engage in this illicit trade was so strong that not even tobacco housed inside the Real Factoría's own tobacco mill was safe. ${ }^{59}$

Reforms enacted by colonial officials in Spain and Cuba sought to stem the tide of contraband and create tighter control over the tobacco monopoly. Sea patrols (guardacostas), the tobacco monopoly police (resguardo), and even reward incentives for those turning in contrabanders were employed in the anti-contraband effort. Despite these measures, the vegueros continued to resist governmental authority and control, an argument far different from the one found in existing studies which suggest that resistance to the monopoly all but ended after the 1723 uprising. Contraband, however, was not the only means by which the tobacco farmers attempted to circumvent the monopoly's regulations. Subtle means of resistance included mishandling of the tobacco, such as packing moist tobacco that resulted in spoilage. Both overt and covert means were used as Cuba's tobacco farmers circumvented the monopoly's regulations, remaining as a source of opposition to colonial authority until the monopoly was rescinded in 1817. This chapter addresses the crown's response to contraband and other means of resistance. As a point of comparison, methods used by other European nations in addressing the problem of contraband are also examined.

The final chapter of this study, Chapter 7, "Cuban Counterpoint Revisited," builds on Fernando Ortiz's seminal work and places tobacco in the context of mid-to-late eighteenth-century rural Cuba. What was tobacco's role both in terms of its social and

$59 \cdot$ Consejo de Yndias, 22 October 1767, legajo 1135, Audiencia de Santo Domingo (herafter SD), AGI. 
economic impact on Cuba and the Spanish Empire as a whole? Challenging the

historiographical view that sugar was supreme during this time, this chapter compares the presence of sugar in locations such as Güines to the influence of tobacco cultivation on the same area. By placing tobacco at the forefront of rural Cuba's agricultural activity, a new approach for how scholars should reconceptualize this period is developed.

This chapter also examines the topics of tobacco, monopoly, and contraband in a broader context of both the Bourbon Reforms, and eighteenth- and early-nineteenthcentury Cuban history. An examination of the illicit trade in tobacco and other methods of avoiding the royal monopoly provides a new insight into some of the economic and military elements of the Bourbon Reforms. While the crown's economic objectives in the Americas were met through its colonial empire's royal tobacco monopolies, five decades of scholarship on all aspects of the Bourbon Reforms demonstrate that the crown was far from being a force that ruled its colonies with an iron hand. Analysis of Spain's attempts to prevent contraband in Cuba reveal the ineffectiveness of the Bourbon Reforms, and the crown itself. By opening up trade, the reforms only legalized an already-existent situation, but did not put an end to contraband and instead such illegal activities continued unthwarted. Despite the crown's enormous efforts, particularly during the latter half of the eighteenth century, the Bourbon Reforms were not universally effective and often contributed to social unrest. 60

60 - D.A. Brading, "Bourbon Spain and Its American Empire," Historical Journal 24, no. 4 (1981): 961-69; Leon G. Campbell, "Recent Research on Bourbon Enlightened Despotism, 1750-1824," The New Scholar 7, no. 1/2 (1978): 29-50; John Lynch, Spanish Colonial Administration, 1782-1810: The Intendent System in the Viceroyalty of the Rio de la Plata (London: Univeristy of London, 1958); Stanley J. Stein, "Bureaucracy and 
Despite the importance of tobacco in Cuban history, scholars in Cuba such as

Raúl Cepero Bonilla, Ramiro Guerra y Sánchez, Manuel Moreno Fraginals, and even

Fernando Ortiz place an overstated emphasis on sugar. ${ }^{61}$ Moreno Fraginals, in particular, sees sugar and the society that developed out of its production as the primary lens through which all Cuban history should be viewed. ${ }^{62}$ Even the great poet of tobacco, Ortiz is sugar-centric when he lamented,

It was sugar that gave us slavery, that was responsible for the conquest of Havana by the English in 1762 , that dictated their leaving in 1763 , that caused the slave trade to flourish, that evaded the restrictions laid upon it, that robbed $\mathrm{Cuba}$ of its liberties throughout the nineteenth century, that brought about and maintains its colonial status and economic backwardness. ${ }^{63}$

Business in the Spanish Empire, 1759-1804: Failure of a Bourbon Refom in Mexico and Peru," Hispanic American Historical Review 61, no. 1 (February 1981): 2-28.

61 Cepero Bonilla, Azúcar y abolición; Ramiro Guerra y Sánchez, José M. Pérez Cabrera, Juan J. Remos, and Emeterio S. Santovenia, Guerras coloniales conflictos y progresos (desde 1697 hasta 1790), vol. 2 of Historia de la nación cubana (La Habana: Editorial Historia de la Nacion Cubana, 1952); Guerra y Sánchez, Pérez Cabrera, Remos, and Santovenia, Ilustración libertad de comercio (desde 1790 hasta 1837); Guerra y Sánchez, Sugar and Society in the Caribbean; Moreno Fraginals, El ingenio; Ortiz, Cuban Counterpoint.

\section{$62 \cdot$ Moreno Fraginals, El ingenio.}

63. Ortiz, Cuban Counterpoint, 69. A similar statement was made about tobacco in the United States. "The staple guaranteed the permanence of the Virginia settlement; created the pattern of the Southern plantation; encouraged the introduction of Negro slavery; then softened the institution; begot an immortal group of colonial leaders; strained the bonds between mother country and Chesapeake colonies; burdened the diplomacy of the post-Revolutionary period; promoted the Louisiana Purchase; and, after the Civil War, helped create the New South." Joseph C. Robert, The Story of Tobacco in America (Chapel Hill: University of North Carolina Press, 1967) quoted in Virginius Dabney, Virginia: The New Dominion, reprint, 1971 (Charlottesville: University Press of Virginia, 1996), 54. 
Historians of colonial Cuba writing in English similarly favor of a model that stresses the spread of sugar cultivation, the elite sugar planters, and slavery. As a result, studies such as those produced by Laird W. Bergad, Robert L. Paquette, and Rebecca J. Scott have dominated the field since the mid-1980s. ${ }^{64}$

Cuban historiography, particularly that of the colonial period, has lagged behind some of the trends found in Latin American historiography such as bottom-up studies of society. ${ }^{65}$ Only now are Cuba's colonial non-elites starting to garner the attention of historians. Innovative new scholarship produced both in Cuba and the United States has moved beyond a sugar-centric focus to reveal the complexity of late-eighteenth- and nineteenth-century Cuba which includes the military, non-sugar-growing rural populations, and free people of color. ${ }^{66}$ Even examinations of slavery itself have moved

64 - Bergad, Cuban Rural Society in the Nineteenth Century; Paquette, Sugar is Made with Blood; Rebecca J. Scott, Slave Emancipation in Cuba: The Transition to Free Labor, 1860-1899 (Princeton, New Jersey: Princeton University Press, 1985).

65. The historiography of Latin America's non-elites, comprising a "history from below" as it is sometimes called, is extensive and includes studies of family, gender, race, and criminality. A brief sampling of works on colonial Mexico alone includes Richard Boyer, Lives of the Bigamists: Marriage, Family, and Community in Colonial Mexico (Albuquerque: University of New Mexico Press, 1995); Asunción Lavrin and Edith B. Courturier, "Dowries and Wills: A View of Women's Socioeconomic Role in Colonial Guadalajara and Puebla, 1640-1790," Hispanic American Historical Review 59, no. 2 (1979): 280-304; Colin A. Palmer, Slaves of the White God: Blacks in Mexico, 15701650 (Cambridge: Harvard University Press, 1976); R. Douglas Cope, The Limits of Racial Domination: Plebeian Society in Colonial Mexico City, 1660-1720 (Madison: The University of Wisconsin Press, 1994); William B. Taylor, Drinking, Homicide, and Rebellion in Colonial Mexican Villages (Stanford, CA: Stanford University Press, 1979).

66. Sherry Johnson, The Social Transformation of Eighteenth-Century Cuba (Gainesville: The University Press of Florida, 2001); Louis A. Pérez, Jr., Winds of 
beyond the sugar plantation and now include studies of eastern Cuba's mines, and coffee estates. ${ }^{67}$ As scholars have discovered for other areas of Latin America, rural non-elites in Cuba played a significant role in defining the shape of rural society.

Ultimately, this study offers a revisionist analysis of colonial Cuban historiography, specifically challenging the primacy of sugar and the image of the veguero as a poor, white, Canary Island farmer who was oppressed by the crown's desire to garner a larger percentage of tobacco profits. Poverty and small-scale farming may have been prevalent among the vegueros, yet Spanish and Cuban archival documents show that tobacco production was not an agricultural enterprise limited exclusively to those who were poor, white, and isleño.

Change: Hurricanes and the Transformation of Nineteenth Century Cuba (Chapel Hill: University of North Carolina Press, 2001); Fé Iglesias, La estructura agrária en el occidente de Cuba 1700-1750 (Manuscript in preparation); Casanovas, Bread, or Bullets!; Michele Bernita Reid, "Negotiating a Slave Regime: Free People of Color in Cuba, 1844-1868," Ph. D. Diss. (Austin, TX: University of Texas at Austin, 2004).

\section{7 . María Elena Díaz, The Virgin, the King, and the Slaves of El Cobre:} Negotiating Freedom in Colonial Cuba, 1670-1780 (Stanford: Stanford University Press, 2000); William C. Van Norman, Jr., "Shade Grown Slavery: Life on a Coffee Plantation in Western Cuba, 1790-1845," Ph. D. Diss. (Chapel Hill, NC: University of North Carolina, 2005). 


\section{Chapter 2:}

\section{From the Field to the Real Factoría de Tabaco}

Tobacco is classified botanically as a member of the Solanacea family which includes many well-known, yet diverse, plants such as nightshade (Atropa Belladonna), Irish potato, red pepper, tomato, petunia, and eggplant. ${ }^{68}$ Varying in height depending on the species and the location where it is grown, tobacco commonly ranges from three to fifteen feet, although a dwarf variety that stood only eighteen inches tall including the flower was discovered in the nineteenth century by Sam Houston at Veracruz, Mexico. ${ }^{69}$ All varieties of tobacco belong to the genus Nicotiana, established by Karl von Linné in 1753 and named for Jean Nicot, a sixteenth century French ambassador to Portugal who introduced the plant to Catherine de Médici in $1560 .{ }^{70}$

Although there is much controversy surrounding by whom or when tobacco was introduced to Europe, there is little doubt that tobacco originated in the New World. ${ }^{71}$

68 - F.W. Fairholt, Tobacco: Its History and Associations: Including an Account of the Plant and Its Manufacture; with Its Modes of Use in All Ages and Countries (London: Chapman and Hall, 1859), 1; W.A. Brennan, Tobacco Leaves: Being a Book of Facts for Smokers (Menasha, WI: Collegiate Press, 1915), 15; Wightman W. Garner, The Production of Tobacco (Philadelphia: Blakiston Company, 1946), 4.

$69 \cdot$ Brennan, Tobacco Leaves, 15.

$70 \cdot$ Ortiz, Cuban Counterpoint, 74; Ibid., 14.

71 . For a sample of the controversy surrounding tobacco's arrival in Europe, see Ortiz, Cuban Counterpoint, 220-23; and Miguel Rodríguez-Ferrer, El tabaco habano: su historia, su cultivo, sus vicisitudes, sus más afamadas vegas en Cuba (Madrid: Imprenta del Colegio Nacional de Sordo-Mudos, 1851), 23-24. For the introduction of tobacco in 
The indigenous people of the Americas and Caribbean knew and used tobacco of one variety or another in four different ways (drinking, chewing, smoking, and inhaling) before the Columbian encounter. Among the South American natives, tobacco was primarily consumed in cigar form, while in North America it was usually smoked in a pipe. The New World's Amerindian societies knew and used other hallucinogenic plants and herbs, but tobacco's effects were more predictable, short-lived, and not lifethreatening. ${ }^{72}$ In some North American tribes "tobacco was so sacred that even its cultivation--much less its use--was forbidden to women..."73 The first known reference to tobacco by Europeans was found in Christopher Columbus's diary of his first voyage to the New World. During inland explorations of eastern Cuba between November 2 and 5 , 1492, two of his men, Rodrigo de Xerez and Luis de Torres, reported seeing the natives using tobacco. ${ }^{74}$

England, see Brennan, Tobacco Leaves, 13; E.R. Billings, Tobacco: Its History, Varities, Culture, Manufacture and Commerce (Hartford, CT: American Publishing, 1875), 38, 81; Garner, The Production of Tobacco, 22; Fairholt, Tobacco: Its History and Associations, 2; Paul R. Johnson, The Economics of the Tobacco Industry (New York: Prageger, 1984), 4; and Rivero Muñiz, Tabaco, 8.

72 - Ortiz, Cuban Counterpoint, 105, 155; Goodman, The Cultures of Dependence, 20-24, 34.

$73 \cdot$ Axton, Tobacco and Kentucky, 20.

74. Ortiz, Cuban Counterpoint, 106-08. 
Tobacco's use as a medicinal herb during the sixteenth century was responsible for the Europeanization of the plant, even though there were strong objections to its use. ${ }^{75}$ The English preferred Spanish tobacco, and before 1612, the first year that John Rolfe planted tobacco in Virginia, much of that country's tobacco came from Spanish America. Pressure from Virginia interests severely limited Spanish tobacco imports, which when taxed gave Virginia tobacco a 600 percent preference. ${ }^{76}$ Consequently, Virginia alone shipped an average of 65,000 pounds of tobacco annually to England during the early 1620s. In light of the increasing demand for tobacco and its profit potential, England founded many new Caribbean colonies for the purpose of growing tobacco. The gamble was a smart one as the plant was "the most profitable staple in the English Caribbean" until nearly mid-century. ${ }^{77}$ Despite these new tobacco-producing areas, they were unable to meet the mother-country's ever-increasing demand. By 1664, Virginia's tobacco

75 - Goodman, The Cultures of Dependence, 54. He also notes, "Tobacco permeated all European social classes at about the same time, in contrast to other exotic substances of the period such as sugar, chocolate, coffee and tea, all of which appear to have entered at the top and percolated downwards." Ibid., 47. The objections to tobacco and the penalties imposed on those who used it are discussed in greater detail in a later chapter.

76 - Leví Marrero, El siglo XVII (II), vol. 4 of Cuba: Economía y sociedad (Madrid: Editorial Playor, 1975), 40; Dabney, Virginia, 25; Goodman, The Cultures of Dependence, 148-49.

77 - Kulikoff, Tobacco and Slaves, 32; Goodman, The Cultures of Dependence, 180. The colonies dedicated to tobacco cultivation included St. Kitts (1624), Barbados (1625), Nevis (1628), Antigua (1632), and Montserrat (1650). Similar attempts were made on Tobago and St. Lucia, but failed. See Davies, The North Atlantic World, 39. 
exports to England had reached 24 million pounds, a figure which would only increase as Maryland, Pennsylvania, and the Carolinas also began to produce tobacco. ${ }^{78}$

England was not the only European country that succumbed to the lure of tobacco, or that turned to its overseas colonies to provide the source. By the end of the seventeenth century, most tobacco entering Spain came from Cuba, so much so that in the 1690s, Cuban tobacco accounted for 83 percent of all tobacco imports into the Spanish port city of Cádiz, up significantly from only 2 percent at mid-century. ${ }^{79}$ Beginning in the 1760 s, Spain created a royal monopoly on tobacco in virtually all of its colonial holdings capable of growing tobacco. Even Louisiana's brief-lived tobacco monopoly, which collapsed by the 1790s as a result of "misguided decisions by both Spanish and Mexican authorities," shipped over 5 million pounds of tobacco to New Spain's royal monopoly during just a ten year period (1778-1788), ${ }^{80}$ As late as the 1860 s, one of Spain's few

$78 \cdot$ Axton, Tobacco and Kentucky, 25.

$79 \cdot$ Goodman, The Cultures of Dependence, 146.

80 - Susan Deans-Smith, "The Money Plant: The Royal Tobacco Monopoly of New Spain, 1765-1821," in The Economies of Mexico and Peru During the Late Colonial Period, 1760-1810, Nils Jacobsen and Hans-Jürgen Puhle (Berlin: Colloquium-Verlag, 1986), 361; Brian E. Coutts, "Boom and Bust: The Rise and Fall of the Tobacco Industry in Spanish Louisiana, 1770-1790," The Americas: A Quarterly Review of Inter-American Cultural History 42, no. 3 (January 1986): 293, 309. Spain's colonial tobacco monopolies and Louisiana's experiment with tobacco are further described in Chapter 4. 
remaining colonial territories, the distant Phillipine Islands, sent over 13.6 million pounds of tobacco annually to Spain from its own royal monopoly. ${ }^{81}$

\section{Tobacco and the Grower}

Before tobacco could be enjoyed in a cigarette, cigar, pipe, or as snuff, it had to be planted, cared for, cut, cured, and processed into its final product. Despite the many steps between the tobacco grower and consumer, the two shared a deep-seated affinity. "Those who grow tobacco describe their attachment to the plant in language more commonly used by those who consume it," one scholar argues. ${ }^{82}$ Climate, soil, seed, and the method of culture all combined to determine tobacco's growth. To ensure a quality final product, however, the farmer also had to take into consideration numerous other factors such as final color, flavor, and aroma. The amount of nicotine, essential oils, and other elements, for example, varied based on when the plant was cut. ${ }^{83}$ A grower's experience in knowing when to transplant the young tobacco plants, or when to cut it, or how long the tobacco should be left to cure only served to improve his chances of success. "The planter who babies his tobacco most is the one who gets the best crop," a nineteenth-

$81 \cdot$ Ed.C. de Jesus, The Tobacco Monopoly in the Philippines: Bureaucratic Enterprise and Social Change 1760-1880 (Manila: Ateneo de Manila University Press, 1980), 165.

82 - Goodman, The Cultures of Dependence, 14.

$83 \cdot$ Brennan, Tobacco Leaves, 21-22. 
century Cuban veguero remarked. ${ }^{84}$ Tobacco cultivation required little in the way of physical capital, but it relied heavily on hand work. Unlike wheat or sugar, there were few slack periods for the tobacco farmer. Tobacco followed a strict schedule, one dictated by the crop itself, and one in which every activity was as important as the last or next. ${ }^{85}$ Yet, not all of the nineteenth-century visitors to Cuba believed that to be the case. American William Morton wrote in his diary, "Their tobacco and corn is planted very thick and gets very little work. The people are generally lazy and do as little as possible." 86

Skilled vegueros possessed valuable knowledge about how to produce a successful tobacco crop, and Spanish officials interested in expanding production elsewhere in the kingdom turned to these men to instruct others. ${ }^{87}$ In the summer of 1811, a royal order was issued stipulating that four Cuban vegueros were to be sent to Peru with four arrobas (100 pounds) of tobacco seed. A public announcement was distributed throughout the island seeking tobacco farmers "with the aptitude necessary for

$84 \cdot$ Ortiz, Cuban Counterpoint, 27.

85 - Breen, Tobacco Culture, 44-55; Ortiz, Cuban Counterpoint, 27-33, 56.

86 . William Morton, "Diaries," diary, Mss2 M8464 b, William Morton Papers (Virginia Historical Society, 1846 and 1847).

87. My research indicates that the majority of Cuban vegueros during this period were men, although there were some women who participated in and sponsored tobacco production, as will be discussed in greater detail in Chapter 3. Social mores of the day, however, make it highly unlikely that women would be sought or permitted to travel to another colony to instruct the residents there on how to produce tobacco. 
the indicated objective." 88 The candidates were to "present themselves to the Secretary of the Superintendency of the tobacco monopoly who will accredit them." 89 The four farmers would promptly be sent to Peru, and, once there, were instructed to "establish the cultivation in that kingdom, and teach those there the method of this crop."90 This would not be the last time that Cuban vegueros and the methods they used to cultivate tobacco were the examples for others in the Spanish Empire. A manual for Venezuelan tobacco farmers published in 1883 , for example, stated that its methods were based on those implemented in Cuba and adapted for Venezuela. ${ }^{91}$

The ever-growing market for tobacco meant that tobacco growers throughout the world were in direct competition with each other, and Spanish authorities made sure to keep informed about their competitors' product. Ultimately, officials wanted to produce

88 - C [name illegible] Arguelles to Superintendente General de la Factoría de Tavacos de la Havana, 28 June 1811, Cádiz, expediente 22, legajo 973, IGH, ANC; Juan Antonio de Unzueta, "Aviso al publico," 17 September 1811, expediente 22, legajo 973, IGH, ANC.

$89 \cdot$ de Unzueta, “Aviso al publico," 17 September 1811, expediente 22, legajo 973, IGH, ANC.

90 - Ibid. This practice of using experts to aid in improving tobacco production elsewhere was not uncommon. During the late eighteenth century when the Polish government wanted to improve the quality and value of their tobacco production, the idea of securing an expert from Virginia was suggested. Jacob M. Price, ed., "Richard Claiborne's Own Account of the Scheme to Introduce Virginia Tobacco Cultivation Into Poland, 1791," Virginia Magazine of History and Biography 83, no. 4 (October 1975): 422-27.

$91 \cdot$ Lino Lopez Mendez, Manual del veguero venezolano. Cultivo del tabaco segun los mejores metodos empleados en Cuba y adaptados a la practica en Venezuela (Cáracas: Imprenta al Vapor de "La Opinion Nacional", 1883). 
the best product possible, and were willing to learn from others in order to do so, including admitting when tobacco growers in other locations were producing a superior product to theirs. In the mid-1770s, Spain's minister of finance, Miguel de Múzquiz, alerted the Marqués de la Torre, Cuba's captain general, that Spain was sending two small bales of Brazilian tobacco with the mail ship and asked that Cuba imitate the "shape, thickness, turned point, and melaazo de las cuendas."92

In his seminal study of slavery in the Americas, Herbert S. Klein compared Virginia and Cuba, describing them as "highly representative" and noting that each was "of prime importance in its geographical and cultural region..."93 Klein's work debuted the same year which one author cites as the emergence of Atlantic history as a scholarly field. ${ }^{94}$ While Slavery in the Americas' objective was to compare each's slave systems, resulting in a study that demonstrated the vast differences between Cuba and Virginia, another historical topic, tobacco, reveals that the two shared many similarities. Indeed, it was Virginia that colonial Cuban tobacco officials turned in order to supplement their

92. Miguel de Múzquiz to Marqués de la Torre, 24 January 1776, El Prado, folio 896-897, legajo 1227, PC, AGI. There are at least two other references to copying Brazilian tobacco, see Miguel de Múzquiz to Marqués de la Torre, 27 December 1775, Madrid, folio 892-893, legajo 1227, PC, AGI; Mateo Echevarria to Marqués de la Torre, 11 November 1776, Santiago de Cuba, legajo 1156, PC, AGI.

93. Klein, Slavery in the Americas, viii.

94 - Gould, "Entangled Histories, Entangled Worlds," 784. For more on a discussion of Atlantic studies as a historical field, see Chapter 1. 
lowered supply of leaf. ${ }^{95}$ Despite the many various procedures involved in tobacco culture, eighteenth- and nineteenth-century farmers in Cuba and Virginia, and even Venezuela, often followed similar practices. Precise determinations for the origin of each detailed step in the tobacco-growing, cutting, and curing process may not be possible, however, it is clear that Cuban tobacco farmers and their counterparts in Virginia and Venezuela generally agreed on what constituted the proper way to grow and harvest tobacco. From the land best suited to the cultivation of tobacco to the preparation of the seed beds, and the method of harvesting the tobacco leaves, contemporary instructions for Cuban, Virginian, and Venezuelan tobacco farmers were remarkably similar.

\section{Choice of Land and Preparation}

Eighteenth- and nineteenth-century tobacco farmers in Cuba, along with those in Virginia and Venezuela, agreed that a slightly sandy soil was best for tobacco cultivation. ${ }^{96}$ Land along rivers or steams in general, was deemed ideal for Cuban,

95 - Josef Pablo Valiente, letter and testimony, 4 July 1799, Havana, number 72, legajo 2000, SD, AGI; Pedro Antonio Gamon to Juan Jose de la Hoz, 24 January 1804, Real Factoría de Tabacos, Havana, number 47, legajo 1060, IGH, ANC; El Interventor General de la Real Factoria de Tabacos de la Habana Dn. Ignacio Gonzalez Cadura, 3 March 1810, legajo 2000, SD, AGI;Table, "Demostración hecha por la Contaduria...tabaco rama Virginia...", Havana, 15 November 1810, legajo 2001, SD, AGI.

96 - de la Sagra, Historia fisica, politica y natural de la isla de Cuba, 288; Un Amigo del Pais, Memoria sobre el tabaco de la isla de Cuba, en la que se indican algunas mejoras de que es susceptible su cultivo y preparacion (Habana: Imprenta de Antonio María Davila, 1852), 5; J.F. Nobiatur, El veguero practico y cientifico, o sea Cultivo perfeccionado del tabaco con el méthodo de preparar convenientemente la hoja, para sus más ventajosa elaboracion, todo con arreglo á kis adelantados modernos (Habana: El Telegrafo, 1874), 5-6; Peter Minor, Notes on the Cultivation and 
Virginian, and Venezuelan farmers alike. One contemporary writer, Martín Fernández Miñano, disagreed and instead recommended hill plots, noting that higher ground was less likely to be damaged by flooding. ${ }^{97}$ The proper way to prepare property for cultivation varied greatly according to the tobacco manuals in these three areas. While de la Sagra's 1839 Cuban manual and Peter Minor's 1822 instructions for Virginia farmers both advocated burning any vegetation standing on the parcel in preparation for planting, by 1874 , J.F. Nobiatur advised Cuban vegueros not burn the land. .98

Over time the ability to continue to find tracts best suited for tobacco cultivation became an issue as many planters argued that tobacco exhausted the soil, requiring crop rotation every couple of years while the land was left fallow. ${ }^{99}$ For Virginia tobacco planters, this meant that new land was continually sought. Settlement and tobacco cultivation in Virginia began in the Tidewater area near the Chesapeake Bay and spread

Management of Tobacco, from the Plant Bed to the Prize; According to the Most Approved Practices in Albemarle, and the Adjacent Counties in Virginia (Baltimore: J. Robinson, 1822), 3; Lopez Mendez, Manual del veguero venezolano, 14,18.

97 - Nobiatur, El veguero practico y cientifico, 6; Martín Fernández Miñano, "Cultura de tabaco en la isla de Cuba," manuscript, Audiencia de Santo Domingo, Legajo 2002, Archivo General de Indias (1788); Minor, Notes on the Cultivation and Management of Tobacco, 3; Lopez Mendez, Manual del veguero venezolano, 17.

98 - de la Sagra, Historia fisica, politica y natural de la isla de Cuba, 288; Minor, Notes on the Cultivation and Management of Tobacco, 3; Nobiatur, El veguero practico y cientifico, 7 .

99 - D.W. Meining, Atlantic America 1492-1800, vol. 1 of The Shaping of America: A Geographical Perspective on 500 Years of History (New Haven: Yale University Press, 1986), 154; Timothy Silver, A New Face on the Countryside: Indians, Colonists, and Slaves in South Atlantic Forests, 1500-1800 (Cambridge: Cambridge University Press, 1990), 163. 
westward. By 1785 , settlers had pushed into what would become Kentucky and began to grow tobacco there. ${ }^{100}$ Late eighteenth and early nineteenth-century Cuban farmers were not concerned with tobacco's impact on soil fertility or the need to rotate crops probably because there was a shortage of land. Additionally, they may have shared the views of Minor who argued in 1822 that tobacco did not exhaust the soil.

Tobacco has been reproached as the canse [sic] of the general exhausted condition of our lands, of the slow paced improvement in the Virginia system of agriculture; in short as the bane of all good husbandry. This stigma, is, I am persuaded, in a great measure unmerited. It is true, that like Indian corn, from the frequent and high degree of tillage it requires throughout the summer, it exposes the ground to be washed by hard rains, and evaporated by the hot sun; but the plant in itself is less an exhauster than corn or wheat. A proof of this is to be found in the superior growth and perfection to which any crop will arrive when grown after tobacco, than after any thing else, not excepting clover that has been ploughed in. ${ }^{101}$

This was not the case, however, with the bureaucrats that ran the Mexican tobacco monopoly who criticized "the seeming ignorance of the planters in their farming practices."102 Not only did Mexican officials reproach the farmers for failing to improve worn-out soil, but also claimed that the tobacco planters insisted on producing "tobacco on any land whether good or bad."103

$100 \cdot$ Brennan, Tobacco Leaves, 43.

$101 \cdot$ Minor, Notes on the Cultivation and Management of Tobacco, 7-8.

102 . Susan Deans-Smith, Bureaucrats, Planters, and Workers: The Making of the Tobacco Monopoly in Bourbon Mexico (Austin: University of Texas Press, 1992), 116.

$103 \cdot$ Ibid. 


\section{Seed Beds, Sowing, and Transplanting}

Where Cuban and Virginian instructions to tobacco farmers agreed that slightly sandy soil was best suited for tobacco fields, there was a divergence of opinion as to the proper location for seed beds. While Minor recommended that Virginia tobacco farmers choose land at the foot of a hill, preferably located near water or a stream, several nineteenth-century Cuban instructions advised the use of virgin land for tobacco seed beds, a practice used since "time immortal."104

Similarly, the best time to sow tobacco seeds in the seed bed was a great source of disagreement among Cuban, Virginian, and other vegueros in the Spanish Empire. Some of this disparity can be attributed to the local climate, however. While Cuban vegueros were advised to sow their seeds over a period of time beginning in October and ending in December, and Venezuelan farmers from November through January, weather in Virginia was far too harsh to start the tobacco seeds at this time. Instead, Minor recommended that the farmers begin sowing the first of February. ${ }^{105}$ Favorable weather conditions in

104 - Minor, Notes on the Cultivation and Management of Tobacco, 14; Un Amigo del Pais, Memoria sobre el tabaco de la isla de Cuba, 7; "Methodo de sembrar y cosechar el Tabaco en la Ysla de Cuba," Audiencia de Santo Domingo (hereafter SD), legajo 2002, Archivo General de Indias (hereafter AGI), Seville, Spain. Some locations skipped this step altogether. In the Dominican Republic during the nineteenth century, tobacco was broadcast directly into the fields instead of being planted first in seed beds. Baud, Peasants and Tobacco in the Dominican Republic, 1870-1930, 58.

105 . Nobiatur, El veguero practico y cientifico, 9; Lopez Mendez, Manual del veguero venezolano, 24; Minor, Notes on the Cultivation and Management of Tobacco, 3. 
the Spanish colonies allowed farmers in Cuba to plant a second seed bed in April, and those in Venezuela to do so in mid-June. ${ }^{106}$

Although tobacco seeds were extremely diminutive in size, one ounce contained approximately 300,000 seeds. A single tobacco plant left to flower and produce seed was capable of supplying one-half an ounce of seeds, sufficient to plant one hundred square yards of seed bed, and "under favorable conditions," seeds from one plant could yield enough seedlings to plant between two and five acres of tobacco. ${ }^{107}$ Put in other terms, one tablespoon of seeds could plant six-and-one-half acres of land in tobacco. ${ }^{108}$

In much the way wheat is sown, tobacco seeds were mixed with fine sand to facilitate distribution and scattered in the seed bed, a 1788 Cuban manual noted. Tobacco farmers in central Virginia and Venezuela also used the same method. ${ }^{109}$ Contact between the seeds and the soil was ensured in several different ways. In Cuba, a palm broom was used to slightly cover the seeds. The ground was tamped by foot in Virginia, whereas in Venezuela the seeds were topped with a small amount of clean ash and sifted

$106 \cdot$ Nobiatur, El veguero practico y cientifico, 9; Lopez Mendez, Manual del veguero venezolano, 20.

107 - T.C. Tso, Physiology and Biochemistry of Tobacco Plants (Stroudsburg, PA: Dowden, Hutchinson and Ross, 1972), 11.

108 - Cigar Institute of America, The Story of Cigars (New York: Cigar Instititute of America, 1942), 17.

109 - Fernández Miñano, "Cultura de tabaco en la isla de Cuba."; Nobiatur, $E l$ veguero practico y cientifico, 8; Lopez Mendez, Manual del veguero venezolano, 21-22. 
fertilizer. ${ }^{110}$ Farmers in Cuba, Venezuela, and Virginia were advised to cover the seed beds with green plantain leaves or brush to protect the plants from damage by rain or sun. At night, however, Cuban farmers removed the covering to allow the young plants to get moisture from dew. Virginia planters also watered their seedlings at night either by using a watering can or taking shaking moistened pine branches over the beds. Extremely cold weather did not pose a problem in either Cuba or Venezuela and as a result the farmers there did not need to remove the brush covering the seed bed in March before the plants came up, retrample the ground, add a dressing of sifted fowl manure, and recover the seed bed, as farmers in Virginia were advised to do in case of severe frost. ${ }^{111}$

Growing tobacco was a multi-step process. Land was prepared for a seed bed, the tiny seeds were sown, and the young tobacco plants later transplanted to their final place in the field. This period of several months was a critical time for the tobacco grower. The farmer routinely grew many more seedlings than he needed for transplanting. A 1788 document, for example, recommended a ratio of three seedlings to one final plant. ${ }^{112}$ Nevertheless, any damage to the seed bed meant a potential loss of the entire year's crop, even before it reached the field. Güines was particularly hard hit in the fall of

$110 \cdot$ Nobiatur, El veguero practico y cientifico, 8-10; Minor, Notes on the Cultivation and Management of Tobacco, 4; Lopez Mendez, Manual del veguero venezolano, 21-22.

111 . Nobiatur, El veguero practico y cientifico, 8; Lopez Mendez, Manual del veguero venezolano, 21-22; Minor, Notes on the Cultivation and Management of Tobacco, 4.

112 · Fernández Miñano, "Cultura de tabaco en la isla de Cuba."; Minor, Notes on the Cultivation and Management of Tobacco, 4. 
1768. A hurricane in mid-October was followed by severe flooding in early November.

Captain Francisco Gama noted that the river "rose like never we have experienced."113

Tobacco was particularly susceptible to damage from flooding, and particularly in a warm climate like Cuba. Standing in water for more than a day caused the plant's roots to die, a condition only hastened in warm soil. The death of the entire root system spelled permanent wilting and a ruined plant, while the destruction of only some of the deeper roots resulted in a wilting of the leaves that would be temporary. Since Captain Gama's report also noted that much of the seedlings in the area's seed beds were destroyed, this indicates that the water did not recede quickly enough. ${ }^{114}$

Tobacco plants were ready for transplanting to their final place in the field when they had four true leaves, which occurred anywhere from two to three months after the seeds were first sown. ${ }^{115}$ Removed from the seed bed, the young tobacco plants were placed in rows approximately 33 inches (one vara) apart, with the distance between the plants themselves approximately 16 to 17 inches (media vara), Cuban tobacco growers

113 . Francisco de Gama to Antonio María Bucareli, 4 November 1768, Güines, legajo 1090, PC, AGI.

114 - George B. Lucas, Diseases of Tobacco (New York: The Scarecrow Press, 1958), 453; Gama to Bucareli, 4 November 1768, Güines, legajo 1090, PC, AGI.

115 . Nobiatur, El veguero practico y cientifico, 12; Minor, Notes on the Cultivation and Management of Tobacco, 4; Lopez Mendez, Manual del veguero venezolano, 23, 27. 
were advised. Once established in the field, one caballería or 33 acres contained an average of 300,000 plants. ${ }^{116}$

\section{Priming, Topping, and Suckering}

As the tobacco plants grew in the field, the farmer's work continued unabated. He had to dispatch pests, address tobacco diseases, control weeds by regular hoeing with an iron hoe that weighed between eight and ten pounds, remove dead plants and replace them with new ones, turn leaves to face upward after a period of high winds, and keep the tobacco plants watered.117 Three other important operations, priming, topping, and suckering, aided in the development of a strong, productive tobacco plant and took place during this time. In priming, several leaves at the bottom of the plant were removed. ${ }^{118}$ These leaves, in contact with the ground, were often damaged by rains or hoeing, and as a result were considered inferior in grade to those higher on the plant. Removing these leaves allowed the plant to use its energy to produce higher quality leaves, in addition to hopefully slowing the access of pests and diseases to the plant. Approximately two

116. "Methodo de sembrar y cosechar el Tabaco en la Ysla de Cuba," not dated, legajo 2002, SD, AGI; Antonio María de Paula Arias, El veguero de Vuelta Abajo. Apuntes sobre el cultivo del tabaco (Pinar del Río, Cuba: Imprenta de Miguel Vives, 1887), 11; Nobiatur, El veguero practico y cientifico, 13; Un Amigo del Pais, Memoria sobre el tabaco de la isla de Cuba, 49.

117 - Fernández Miñano, "Cultura de tabaco en la isla de Cuba."; Un Amigo del Pais, Memoria sobre el tabaco de la isla de Cuba, 25; Nobiatur, El veguero practico y cientifico, 16; "Methodo de sembrar y cosechar el Tabaco en la Ysla de Cuba," Audiencia de Santo Domingo, Legajo 2002, Archivo General de Indias (N.d.). 
months after the tobacco was transplanted, the grower engaged in a practice known as "topping" or "debuttoning," in which he made his way through the fields early in the morning, pinching off with his thumbnail the top of the plant including the newly-formed cluster of pink flowers and several leaves. This allowed the plant to concentrate its energy on the development of the leaves rather than seed production, and was where the expertise of the veguero became evident. Using unskilled labor in this vital operation could be disastrous, as it was essential that the appropriate number of leaves be left on each plant. ${ }^{119}$ Topping the tobacco, however, prompted the growth of offshoots at the base of the plant, called "suckers" in Virginia and "hijos" in Cuba, that also had to be removed lest the plant's overall leaf quality suffer. ${ }^{120}$

\section{Cutting and Curing}

After months of tending to the tender tobacco plants as they lay under the protective covering of the seed bed, to selecting the leaves that would remain on the plant, the veguero had reached another critical point in the plant's transition to the final product. If the tobacco was cut while the leaves were too dry, they were brittle and would break, if

118 - Lopez Mendez, Manual del veguero venezolano, 34; Minor, Notes on the Cultivation and Management of Tobacco, 6.

119 · Fernández Miñano, "Cultura de tabaco en la isla de Cuba."; "Methodo de sembrar y cosechar el Tabaco en la Ysla de Cuba."; Nobiatur, El veguero practico y cientifico, 17; Minor, Notes on the Cultivation and Management of Tobacco, 6; Lopez Mendez, Manual del veguero venezolano, 36.

120 • Fernández Miñano, "Cultura de tabaco en la isla de Cuba."; Minor, Notes on the Cultivation and Management of Tobacco, 6 . 
too moist the tobacco would rot in the curing barn. In short, the farmer attempted to balance the need to place his tobacco within the safety of the barn against keeping it longer in the field until it reached its maximum point of maturity when it would weigh more, and therefore bring the planter a higher profit. This process was extremely vital, so much so that Virginia's Landon Carter and his contemporaries believed that a farmer's success and ultimately his reputation hinged on making the right decision regarding the proper time to cut tobacco. ${ }^{121}$

Knowing when tobacco was at the appropriate state of maturity was difficult at best, as a nineteenth-century tobacco manual acknowledged, "It is difficult to convey an idea of ripe tobacco by description. It can only be learnt by observation and experience." 122 However, there were several indicators by which farmers determined that the tobacco was ripe, although they did not occur simultaneously. A change in the color of tobacco leaves from gray-green to a yellowish-orange, sometimes in spots, and the downward turning of the leaves toward the ground were two of the signs that farmers from Cuba to Virginia to Venezuela agreed were indications that the tobacco was ready for cutting. ${ }^{123}$

$121 \cdot$ Breen, Tobacco Culture, 49-50, 63-68; Minor, Notes on the Cultivation and Management of Tobacco, 8.

$122 \cdot$ Minor, Notes on the Cultivation and Management of Tobacco, 8.

123 . "Methodo de sembrar y cosechar el Tabaco en la Ysla de Cuba."; Un Amigo del Pais, Memoria sobre el tabaco de la isla de Cuba, 27; Ibid.; Lopez Mendez, Manual del veguero venezolano, 42. 
Cutting, as with other operations, differed some from region to region. Period instructions to tobacco farmers from Cuba to Virginia recommended cutting during the day. More specifically, Cuban farmers removed tobacco leaves during mid-day from 9 in the morning until 2 in the afternoon during the months of September and October. If the weather was hot and dry, an unusual occurrence for late summer, Virginia farmers cut tobacco before 10 in the morning or during the evening, and otherwise also cut tobacco during the heat of the day. The method of removing the plant from the field varied more however. Cuban farmers broke the leaves off of the tobacco plant and held them on his left arm until he had between forty-five and fifty leaves. He then laid the leaves on the ground to dry in the sun for six to eight minutes, and then collected them. Placing the now-dry leaves on a piece of leather called a "burro," the veguero carried them to the tobacco house. A 1788 document noted that a slave could carry between eight and ten arrobas (200 to 250 pounds) on his head. ${ }^{124}$ In Virginia, the farmers went between two rows, cutting the tobacco stalk to within six inches of the ground and then slicing the stalk upward to just below the bottom leaf. The cut tobacco plant was then stood upright in the row or propped and turned so that the sun could make the leaves pliable for handling. When ready, the stalks were placed in a circle and covered with green brush to prevent sun scorch. ${ }^{125}$

124 · Fernández Miñano, "Cultura de tabaco en la isla de Cuba."; Nobiatur, $E l$ veguero practico y cientifico, 19; "Methodo de sembrar y cosechar el Tabaco en la Ysla de Cuba."

$125 \cdot$ Minor, Notes on the Cultivation and Management of Tobacco, 9. 
Both Cuban and Virginian tobacco growers took their product to four-sided

wooden barns. The tobacco was then placed on sticks stretched between poles that ran parallel to the ground. At that time, two methods were used to cure tobacco. One of these, used in Cuba and Virginia, was air-curing in which air was allowed to circulate through the hanging leaves, and closed at night or during colder temperatures. In this method, it was important that the tobacco be sufficiently dry and that there was sufficient space between each pole so that there was sufficient ventilation. If not, mold could develop on the stems and leaves which would rain the quality of the product. The other method, used throughout the United States, was fire-curing. The barn was made airtight, the sticks of tobacco packed tightly together, and heat introduced into the barn with the temperature raised slowly over a period of time until the leaves turned a light brown. ${ }^{126}$

\section{Packing the Tobacco for Market}

The beginning of the rainy season in Cuba in the spring spelled an increase in atmospheric humidity, making the now-dry leaves more flexible, allowing for safe movement of the crop without risking breakage. The leaves were then carefully separated into different piles based on their quality and covered with plantain leaves to protect them. If the tobacco was in good condition, dry plantain leaves were used, while green leaves were reserved for tobacco that had become too dry and needed additional moisture. The piles were then placed three fingers high on elevated benches above the ground

126 · Fernández Miñano, "Cultura de tabaco en la isla de Cuba."; Nobiatur, El veguero practico y cientifico, 19-20; Ibid., 9-11. 
where they were wet down with a brash or sponge on the top and bottom, another pile placed on top and again moistened from above and below until a certain amount had been treated thusly. The tobacco was later returned to hang in the tobacco houses to complete the curing process. ${ }^{127}$ Tobacco was then prepared for market by placing it into manageable bundles. Each leaf was lined up at its widest part with the central veins together. Depending on the quality, between 25 and 40 leaves were paired in this way, and tied at the top with an additional leaf in what was known as a gavilla or carrot. Four gavillas tied together with string became known as a manojo or bundle. ${ }^{128}$

\section{Weather and Pests}

A veguero's knowledge certainly helped to ensure his success in bringing the crop to market, yet even the most seasoned farmer could do little when confronted by an uncooperative Mother Nature. Too little rain or too much in the form of hurricanes and other tropical systems were just two of the many natural hazards that confronted Cuba's eighteenth and nineteenth-century vegueros. Due to lack of rainfall during the previous planting season, many vegas in Oriente remained unplanted in March 1752, the region's governor Alonso Arcos y Moreno reported. As a result, the region produced just over 93,000 manojos (bundles) of tobacco, down from a typical year which saw 150,000

127 . Nobiatur, El veguero practico y cientifico, 20-24.

$128 \cdot$ Ibid., 24-25. 
bundles delivered to the monopoly. ${ }^{129}$ From 1763 to 1817 , new research reveals that

Cuba was plagued by frequent droughts, particularly during the winters of the 1790s. A scarcity of rain in 1769 and again in 1792 resulted in a smaller than expected tobacco crop, disappointing not only the growers, but royal officials as well.130

Whereas the lack of rain resulted in a smaller crop, flooding, sometimes associated with hurricanes or other storms, also damaged the island's tobacco industry. During the summer of 1755 , an official in eastern Cuba alerted Havana that recent floodings of some of the rivers had damaged "many vegas."131 At least four separate storms between 1768 and 1777 caused damage to the Cuban tobacco industry, both in terms of plants lost in the field and damage to the infrastructure such as tobacco houses. A local official alerted Captain General Antonio María de Bucareli that a hurricane hit Guanabacoa, located just east of Havana, on October 15, 1768 and destroyed 28 tobacco houses, while 60 remained standing in that area. This storm was soon followed by severe flooding to "levels we have never seen before" near Güines, which Francisco Gama

129. Alonso Arcos y Moreno to Francisco Cagigal de la Vega, 27 March 1752, Santiago de Cuba, expediente 74, legajo 6, CG, ANC; Johnson, El Niño's Atlantic World.

130 - Johnson, Sherry, El Niño's Atlantic World; Julián de Arriaga to Antonio María Bucareli, 18 July 1769, Madrid, expediente 24, legajo 1134, PC, AGI; letter, 3 May 1792 , legajo 1461, PC, AGI. Johnson notes that periods of drought were usually followed by active hurricane cycles.

131 - El Apoderado de la Real Compañia to Captain General, 1 August 1755, Santiago de Cuba, orden 407, legajo 7, CG, ANC. 
lamented was a "second serious blow," that damaged the area's tobacco crop. ${ }^{132}$ A hurricane in November 1774 brought destruction to Managua, leaving "the tobacco houses (are) on the ground, only two have remained standing." 133 That same storm also damaged vegas in Rio Blanco, causing a local official to lament that the possibility of a good harvest was now lost. Tobacco plants in the field were damaged as were the houses where the crop was stored in Govea and Güines. In Güines alone, 240 tobacco houses along with 273,300 tobacco plants were damaged.134 "A strong storm (temporal) of rain and wind, that lasted seven continuous days... without weakening the drive of both elements" seriously damaged eastern Cuba's tobacco crop in November 1777. Mateo de Echevarria y Elguerra, the local monopoly representative (factor), wrote to Captain General Diego José Navarro that the rivers had risen so much that the seed beds and

$132 \cdot$ Joseph de [unclear], "Estado que manifiesta las ruinas que ocasiono el urucán [sic] del dia quinze de este mes en las estancias e Ynjenios [sic] qu ai en los Partidos de esta Juridicion con distincion de la fabricas de texa, guano, cozinas, casas de tavaco, de vibienda, de molienda, de purga y secaderos," 25 October 1768, Guanabacoa, legajo 1090, PC, AGI; Francisco Gama to Antonio María Bucareli, 4 November 1768, Güines, legajo 1090, PC, AGI.90, PC, AGI. This same October 15 hurricane causing the sea to wash over 69 ships in Havana's harbor, ultimately destroying three. See Francisco Escobar Guío, "Naufragios en la Bahía de La Habana en el período colonial," in La Habana, puerto colonial siglos XVIII-XIX, edited by Agustín Guimerá, Fernando Monge (Madrid: Fundación Portuaria, 2000), 232-33.

133 . Vicente de Mesa to Marqués de la Torre, 13 November 1774, Managua, legajo 1193, PC, AGI.

134 . Manuel Ramos to Marqués de la Torre, Río Blanco, 10 November 1774 , legajo 1194, PC, AGI; Francisco de la Cruz Valiente to Marqués de la Torre, 14 November 1774, Govea, legajo 1196, PC, AGI; Sebastian de la Cruz to Marqués de la Torre, 17 November 1774, Güines, legajo 1193, PC, AGI; Sebastian de la Cruz to Marqués de la Torre, 19 November 1774, Güines, legajo 1193, PC, AGI. 
fields where tobacco was under preparation for planting were now "laid flat."135 As a result, the following year's crop, de Echevarria warned, would be "reduced or none."136 During the 1790 s, seven hurricanes impacting the island and negatively affected the island's tobacco industry. In addition, typical storms also caused destruction as a letter written in April 1795 cited damage to the tobacco seed beds as a result of recent storms. ${ }^{137}$

If climatic factors were not enough, tobacco was also subject to damage by pests. As one nineteenth-century writer noted, tobacco worms were "the only animal, save man, which is life-proof against the deadly nicotine of this cultivated poison." 138 One in particular, the green hornworm, described as "the worm that never dies,"” was especially destructive. ${ }^{139}$ To paraphrase the old saying, the cure was nearly as bad as the disease. "The act of destroying these worms is termed worming the tobacco, which is a very nauseous occupation, and takes up much labor. It is performed by picking everything of this kind off the respective leaves with the hand, and destroying it with the foot," William

135 - Mateo de Echevarria y Elguerra to Diego José Navarro, 9 December 1777, Santiago de Cuba, legajo 1231, PC, AGI.

$136 \cdot$ Ibid.

137 · Johnson, Sherry, El Niño's Atlantic World; Relación, 25 April 1795, number 41, legajo 2612, AGI.

138 - St. George Tucker, Hansford: A Tale of Bacon's Rebellion (Richmond, VA: George M. West, 1857), 15.

139 . Joseph Clarke Robert, The Tobacco Kingdom: Plantation, Market, and Factory in Virginia and North Carolina, 1800-1860, reprint, NC: Duke University Press, 1938 (Gloucester, MA: Peter Smith, 1965), 37. 
Tatham wrote in $1800 .{ }^{140}$ Another method of pest control employed by Virginia and North Carolina farmers was to let guinea fowl or turkeys into the fields to eat the worms. ${ }^{141}$

\section{On to the Real Factoria}

Cuba's vegueros presented their tobacco to the monopoly at purchasing fairs that were held between August and the end of October. ${ }^{142}$ Money to pay the local vegueros for their crop ideally should be already in place, delivered from Havana by trusted men escorted by armed cavalrymen as was the case during the 1750 s when arriero (muleteer) Pedro Hernández and Lieutenant (junior grade) don Manuel de Quintana regularly delivered funds to eastern Cuba to pay for the area's tobacco harvest. Between 1751 and 1755, the pair transported almost 140,000 pesos to Oriente's local tobacco factorias. In August of 1769, José Aguilar and Fabian Herrera arrived in Puerto Príncipe carrying money designated for the purchase of local tobacco. From there, the pair headed east toward Santiago de Cuba on August 5, escorted by four dragoons. ${ }^{143}$ Correspondence

140 - G. Melvin Herndon, ed., William Tatham and the Culture of Tobacco (Coral Gables, FL: University of Miami Press, 1969), 22.

141 . Robert, Joseph Clarke, The Tobacco Kingdom, 37.

142 . Governor of Cuba to Francisco Cagigal de la Vega, 2 September 1752, Santiago de Cuba, order 195, legajo 6, CG, ANC; Francisco Cagigal de la Vega to Alonso Arcos y Moreno, 25 October 1752, Havana, order 299, CG 6, ANC; Joaquin de Sola to Marqués de la Torre, 6 July 1776, Puerto Principe, legajo 165, PC, AGI.

143 - Ramón Vuelta Flores to Antonio María Bucareli, 20 August 1769, Puerto Príncipe, legajo 1074, PC, AGI. 
reflects the ongoing scramble by colonial officials to find money that could be allocated to pay the tobacco farmers, but frequently funds to pay the vegueros did not materialize by the time that the tobacco was delivered to the fairs. ${ }^{144} \mathrm{~A}$ veguero from Bayamo complained about this very situation, noting that they were often given promissory notes when they turned in their crop, since the local monopoly's account was in arrears. Blame was sometimes placed at the feet of the local monopoly representative, the factor. ${ }^{145}$ Yet, there was little that the tobacco farmers could do, although some vegueros in eastern Cuba took matters into their own hands and refused to pay for the construction of a bridge until they were reimbursed for the tobacco they had delivered to the monopoly. ${ }^{146}$

Tobacco coming from the areas around Havana was transported by mules and muleteer, and was notoriously unreliable. It was "very difficult," a local official complained, to bring tobacco from the partido of Macuriges to Havana, some forty

144 - Francisco Cagigal de la Vega to Lorenzo de Madariaga, 6 September 1754, Havana, legajo 6, CG, ANC; Manuel del Portillo to Marqués de la Torre, 20 July 1775, Sancti Spíritus, document 82, legajo 1185, PC, AGI; Juan Merconelniny [surname unclear], "Razon de todas las deudas que tiene esta Factoria sublterna de mi cardo con explicacion de anos y demas segun se me pide por el Sr Superintendente director General del ramo,"15 December 1808, Bayamo, expediente 16, legajo 96, IGH, ANC.

145. Marqués de la Torre to Josef de Albanado, 20 April 1772, Havana, folio 310-311, legajo 1179, PC, AGI; Marqués de la Torre to unknown, 11 August 1774, Havana, legajo 1144, PC, AGI; Juan Antonio Ayans de Ureta to Pascual de Cisneros and Marqués de la Torre, 4 September 1774, Santiago de Cuba, document 225, legajo 1142 , PC, AGI.

146. Marqués de la Torre to Matheo de Echevarria y Elguerrua, 11 August 1775 , Havana, legajo 1156, PC, AGI. 
leagues distant, particularly with a shipping system that was deemed as "impossible."147 In mid-November of 1775 , captain general Marqués de la Torre notified the magistrates (alcaldes) in San Felipe and Santiago de Bejucal that muleteers (arrieros) were needed to bring tobacco from the Vuelta Abajo to the Real Factoría. In less than a week, Domingo de la Cruz wrote back from Santiago that the needed arrieros and their horses had been secured. Led by arriero foreman Juan Gonzalez, a total of 15 additional men--Francisco Alonzo, Antonio Beltran, Felix Castellaño, Juan Farias, Isidoro Garcia, Antonio Gomez, Francisco Gonzalez, Pedro Hernandez, Franscisco Isquierdo, José de Leon, José Marrero, Juan Padron, Esteban Pastrana, Blas Rivero, and Juan Tavarez--along with 125 horses left Santiago on November 29 and head for the Vuelta Abajo. ${ }^{148}$ By the following spring, however, it was clear that securing arrieros to bring tobacco from the outlying areas into Havana would be problematic. The Marqués de la Torre assured Santiago's alcaldes that muletters would come by Güines with approximately 23 animals to collect green tobacco, and told those in Bejucal that they should expect arrieros with about 50 animals. On April 26, however, a local official in Bejucal complained that some arrieros were away, while others did not have the animals needed to carry tobacco the city. ${ }^{149}$ Other factors

147 Ambrocio Pérez Baes to Marqués de la Torre, 8 December 1772, Partido de Macuriges, legajo 1193, PC, AGI.

148 - Marqués de la Torre to Alcaldes de San Felipe y Santiago, 15 November 1775, Havana, legajo 1167, PC, AGI; Domingo de la Cruz to Marqués de la Torre, 21 November 1775, Santiago, legajo 1167, PC, AGI.

149. Marqués de la Torre to Alcaldes de la ciudad de Santiago, 29 March 1776, Havana, legajo 1167, PC, AGI; Marqués de la Torre to Alcaldes de San Felipe y Santiago 
such as damage to the island's infrastructure only added to the transportation difficulties.

In February of 1801, the island's intendant, Luis de Viguri, informed Miguel Cayetano Soler, Spain's finance minister, of the urgent need to repair the road from the Suridero del Batabanó on the southern coast, made "impassable" by recent storms. ${ }^{150}$

Tobacco traveling longer distances, such as that from the eastern part of the island, came by sea. Throughout the summer, fall and winter, tobacco gathered and purchased from local eastern vegueros was placed on ships leaving from Bayamo, Santiago de Cuba, Puerto Príncipe, or Holguín, and sent west toward Havana. These vessels off-loaded their cargoes at the Surgidero de Batabanó on the southern coast, where the tobacco was taken overland to the royal monopoly building in Havana. Vessels of varying sizes ranging from a small launch (lancha) to a schooner (goleta) travelled down the winding Bayamo River in June carrying tobacco from Bayamo, while three other ships stood ready to take additional cargoes. ${ }^{151}$ On August 25, 1770, Captain don Joseph Garcia guided the schooner San Francisco de Paula through the Bay of Santiago de Cuba, past the Castillo de San Pedro de la Roca, the city's multi-level Morro Castle perched high on a cliff overlooking the water, and into the open Caribbean Sea, turning west toward Havana. In the ship's hold was a load of 2,900 arrobas (approximately

de Bejucal, 29 March 1776, Havana, legajo 1167, PC, AGI; Mathias de la Cruz to Marqués de la Torre, 26 April 1776, Bejucal, legajo 1167, PC, AGI.

150 . Luis de Viguri to Miguel Cayetano Soler, 8 February 1801, Havana, letter number 89 , legajo 2000, SD, AGI.

151 - Miguel Ibáñez Cuevas to Antonio María Bucareli, 26 June 1766, Bayamo, legajo 1080, PC, AGI; Juan Gemir y Lleonart to Antonio María Bucareli, 12 June 1767, Bayamo, legajo 1080, PC, AGI. 
73,515 pounds) of tobacco destined for the royal monopoly. In January of 1774 , and

August of 1775 , additional ships made the same journey. ${ }^{152}$ Tobacco coming from Puerto

Príncipe and Holguín frequently left in the fall. 153

The volume of tobacco shipped from the interior of the island and destined for Havana is demonstrated in a sampling of shipping bills (facturas) from eastern Cuba.

Between the summer of 1766 and the end of January of $1768,15,583$ arrobas

(approximately 395,029 pounds) of tobacco were shipped from Bayamo alone. A sizable portion of this tobacco was shipped out simultaneously to make the journey from Bayamo up the coast toward the Surgidero de Batabanó. In just one day, October 19, 1767, a little more than 128,245 pounds $(5,059$ arrobas $)$ of tobacco were loaded aboard the schooners Santisima Trinidad, Nuestra Señora de la Concepción, and Nuestra Señora del Carmen piloted by Bartholome Garcia, Pedro Alcala, and Estevan Cruz, respectively. On another

152 - Matheo de Echevarria to Antonio María Bucareli, 25 August 1770, Santiago de Cuba, legajo 1080, PC, AGI; Juan Antonio Royo, "Relacion de las Embarcaciones que han entrado y salido por este Puerto de la Boca del Morro de Santiago de Cuba desde prim $^{0}$ de Henro [sic] de 1774 hasta fin del dho," 4 February 1774, Castillo del Morro, Santiago de Cuba, legajo 1141, PC, AGI; Jane McManus, Getting to Know Cuba: A Travel Guide (New York: St. Martin's Press, 1989), 153-54; Governor of the Plaza de Cuba to Marqués de la Torre, 22 September 1775, Santiago de Cuba, document 37, legajo 1142, PC, AGI.

153 - Antonio María Bucareli to Miguel Ibáñes Cuebas, 8 September 1768, Havana, legajo 1077, PC, AGI; Antonio María Bucareli to Miguel Ibáñez Cuebas, 20 November 1768, document 86, legajo 1077, PC, AGI; Ramón Vuelta Flores to Antonio María Bucareli, 20 September 1769, Puerto Príncipe, legajo 1074, PC, AGI; Ramón Vuelta Flores to Antonio María Bucareli, 26 October 1769, Puerto Príncipe, legajo 1074, PC, AGI; Antonio de Luque to Marqués de la Torre, 25 October 1772, Holguín, document 2, legajo 1144, PC, AGI; Antionio de Luque to Marqués de la Torre, 1 March 1773, Holguín, document 3, legajo 1144, PC, AGI; Antonio de Luque to Marqués de la Torre, 14 October 1773, Holguín, document 4, legajo 1144, PC, AGI. 
occasion, January 2,1768 , the same three ships, although this time the Santisima

Trinidad was captained by Angel de Vargas, again made the journey now loaded with 4,998 arrobas (approximately 126,699 pounds) of tobacco. ${ }^{154}$ Yet, even though the plant was now under the monopoly's control, threats from contrabanders or pirates still remained, so much so that in November of 1779 , a local official in Trinidad alerted the captain general that the area's tobacco was ready for shipment. In order to facilitate transportation and ensure that there would be no problems, the commander of the coast guard assembled a convoy to accompany the tobacco, which was to be carried by boat to Batabanó. ${ }^{155}$

Once tobacco reached Havana, it was taken to the Real Fabrica de Tabacos, a large quadrangular building with massive and high walls that was constructed by the government in the mid-1770s. The building was located along the bay, just south of the arsenal outside of the city's protective muralla (wall) near the Puerta de la Tierra, one of

154 - Ibáñez Cuebas to Bucareli, 26 June 1766, Bayamo, legajo 1080, PC, AGI; Gemir y Lleonart to Bucareli, 12 June 1767, Bayamo, legajo 1080, PC, AGI; Gemir y Lleonart to Bucareli, 22 August 1767, Bayamo, legajo 1080, PC, AGI; Juan Gemir y Lleonart to Antonio María Bucareli, 19 October 1767, Bayamo, legajo 1080, PC, AGI; Juan Gemir y Lleonart to Antonio María Bucareli, 19 October 1767, Bayamo, legajo 1080, PC, AGI; Juan Gemir y Lleonart to Antonio María Bucareli, 19 October 1767, Bayamo, legajo 1080, PC, AGI; Juan Gemir y Lleonart to Antonio María Bucareli, 14 November 1767, Bayamo, legajo 1080, PC, AGI; Juan Gemir y Lleonart to Antonio María Bucareli, 2 January 1768, Bayamo, legajo 1080, PC, AGI; Juan Gemir y Lleonart to Antonio María Bucareli, 2 January 1768, Bayamo, legajo 1080, PC, AGI; Juan Gemir y Lleonart to Antonio María Bucareli, 2 January 1768, Bayamo, legajo 1080, PC, AGI; Juan Gemir y Lleonart to Antonio María Bucareli, 15 January 1768, Bayamo, legajo 1080, PC, AGI.

155. Fernando Muñoz to captain general, 10 November 1779, Trinidad, document 174, legajo 1260, PC, AGI. 
the entrances into the fortified city. Access to the factory was by way of a road that ran toward the muralla where a new entrance was proposed as a substitute for the Puerta de la Tenaza. Barrels of tobacco arriving by sea from the interior were unloaded by a large wooden water-powered crane known as La Machina on the nearby Muelle de la Factoría (Monopoly Wharf). The crane was relatively new in its construction, and water used to operate the wheel traveled through mahogany tubes joined by copper rings, already turning green from oxidation. All tobacco, whether it was destined for Spain or elsewhere, passed through the well-secured entrances into the lower level with its several large, open interior squares including a central one complete with a fountain. Ground tobacco, first processed at water-powered mills (molinos) in the interior of Cuba, was reground to a finer consistency by horse-driven stone mills on the building's ground level which boasted 20-foot-ceilings and brick floors, while free and slave workers produced cigars on an upper story. ${ }^{156}$

Even in the possession of the Real Factoria, tobacco was not safe from the ravages of nature, which could easily wipe out a sizable portion of the tobacco stored inside the monopoly's buildings. Between September 15 and 21, 1778, rains "like never

156. Samuel Hazard, Cuba with Pen and Pencil, reprint, 1871 (Miami: Editorial Cubana, 1989), 215; John George F. Wurdemann, Notes on Cuba (Boston: James Munroe and Company, 1844), 32-34, 57-59, 220-25, 228-35 reprinted in Louis A. Pérez, Jr., ed., Slaves, Sugar, and Colonial Society: Travel Accounts of Cuba, 1801-1899 (Wilmington, Delaware: Scholarly Resources, 1992), 195-97; Richard Henry Dana, To Cuba and Back: A Vacation Voyage (Boston: Ticknor and Fields, 1859), 183-88 reprinted in Pérez, Louis A., Jr., Slaves, Sugar, and Colonial Society, 199; Johnson, Sherry, Social Transformation, 29; Marrero, Azúcar, ilustración y conciencia (1763-1868)(III), vol. 11 of Cuba: economía y sociedad, 8. Johnson notes that the original crane had been destroyed during the British occupation of Havana (1762-1763). For more on the construction of the Real Fabrica de Tabacos, see Chapter 5. 
seen before" virtually destroyed the contents of the new tobacco monopoly building, constructed just several years before, and four warehouses, all of which were full of the best quality tobacco. ${ }^{157}$ The "weight of the water undermined the walls," of warehouses one through four, while in almacenes (warehouses) five through nine, and number thirteen, there was no way for the water entering them to escape. ${ }^{158}$ Meanwhile, water rose five-and-a-half feet (two varas) in the warehouses without roofs. Although the zanja (ditch) was ordered opened, and tobacco was taken to the Real Hacienda's headquarters since the monopoly's own facilities were full, it was with little effect. Just three days later, however, Captain General Navarro was reassured that the buildings were now dry and ready for tobacco. 159

After it was processed, tobacco was repacked and placed by the wooden $L a$ Machina crane onto various types of ships including frigates (fragatas) and packet ships (paquebotes) for the long and often treacherous Atlantic voyage to Spain. For the most part, an attempt was made to avoid the hurricane season with increasing numbers of ships carrying Cuba's tobacco shipments setting sail as the fall progressed. ${ }^{160}$ Tobacco could AGI.

157 - Luis Prieto to Diego José Navarro, 24 September 1778, Havana, PC 1247,

$158 \cdot$ Ibid

$159 \cdot$ Ibid.

160 - Martín Xavier de Echevarria, "Estado en que se manifiesta el peso de 4066 Zurrones de Tavaco de Polvo, y 7642 terzios de Rama entregados por la Factoría de la Havana para su conducíon a Cadiz á los Maestres de 16 Embarcaziones que íran relacíonadas, cotejado con el que tubíeron a su arrívo en aquel Puerto, y a su ingreso en las Rs Fabricas de Sevilla, y las diferencias de aumentos, y mermas de cada genero, y 
also be lost in shipment, either from one point on the island to the other, or in transit to

Seville. As the result of a storm, most likely a hurricane, in late October of 1768 , the schooner Juan Antonio Candelario was lost in the mouth of the Guanabo River with 112 tercios (bundles) of tobacco aboard, of which 30 were eventually recovered. Other dangers were less dramatic such as the accident that resulted in the loss of all but 40 tercios of tobacco from the goleta Nuestra Señora del Carmen. Captain Estevan Cruz reported that the ship, carrying 224 tercios of tobacco, struck a submerged stick in the water about two leagues from Bayamo and took on water. ${ }^{161}$ In the fall of 1771 , tobacco bound for the Real Fabrica de Sevilla on board the ship San Antonio, also known as the Maria, was lost along the Punta de Guarico, just up the coast from Baracoa, Cuba's captain general informed the minister of the Indies, Julián de Arriaga. ${ }^{162}$

Another viable threat to the tobacco shipment was wartime, which further complicated the already treacherous Atlantic crossing. In early 1800 , Cuba's intendant Luis de Viguri noted that the war had made it difficult for ships leaving from Cuba to

remesa en ambas partes, dispuesto con presencia de los Documentos en que todo consta, a saber las Facturas y Conocimientos que los acompañaron, un Estado, y razon del peso en Cadiz formado en 22 de Junio de este año por dn Anto Garcia Cossio contador de aquella Administrazn Pral de la Renta, y 16 Testimonios de reconocimiento, y peso de los mismos Tavacos ejecutado en las referidas Fabricas que es como se sigue," 24 September 1773, Havana, legajo 1227, PC, AGI.

161 . Juan Miguel de Arocena, Lieutenant Governor of Quatro Villas, to Governor and Captain General Antonio María Bucareli, 29 October 1768, Trinidad, document 46, legajo 1079, PC, AGI; Juan Gemir y Lleonart to Antonio María Bucareli, 18 January 1768, Bayamo, legajo 1080, PC, AGI.

162 - Antonio María Bucareli to Juliaán de Arriaga, 8 October 1771, Havana, document 72, legajo 1140, PC, AGI. 
reach Spain. Viguri stated that he had considered sending an American ship loaded with tobacco to go to the north and take on "false papers as if it was American property" and from there head to the first available port in Spain. ${ }^{163}$ This would not be the first time that Cuban tobacco bound for Spain had left on a foreign ship. On October 8, 1771, a Swiss vessel, the Arditia, left Havana carrying a load of tobacco destined for Seville's tobacco factory. ${ }^{164}$

From Havana, the ships headed through the Straights of Florida and out into the open Atlantic. Their destination was Cadíz, the seat of all commercial activity with the peninsula since May 8, 1717 when King Felipe V moved the two key institutions, the Casa de la Contratación and the Consulado, to the southern Spanish port city. Tobacco then traveled north to the city of Seville where it was processed in the enormous Real Factoria de Tabacos, a building unfairly described by one nineteenth-century traveler as "utterly devoid of architectural merit..."165 Increasing demand during the eighteenth century made Seville's original seventeenth-century San Pedro fábrica obsolete and as early as 1725 plans were underway to construct a new tobacco factory. The massive tobacco complex, begun in 1758 and finally completed in 1770 at a reported cost of 37

163 . Luis de Viguri to Miguel Cayetano Soler, 14 March 1800, Havana, legajo 2000, SD, AGI.

$164 \cdot$ unknown to Julian de Arriaga, 8 October 1771, Havana, document 70, legajo 1140, PC, AGI.

165 - Ibid; Marrero, Del monopolio hacia la libertad comercial (1701-1763)(II), vol. 7 of Cuba: economía y sociedad, 96; John Esaias Warren, Vagamundo; or the Attaché in Spain: Including a Brief Excursion Into the Empire of Morocco (New York: Charles Scribner, 1851), 150. 
million reales, was 662 feet in length and 524 feet wide and contained over two dozen courtyards or patios, 21 fountains, 10 wells, a jail, churches, and houses for the superintendent of the tobacco monopoly and other key officials. After tobacco passed over the deep moat, it entered through the columned facade of the main building with its depictions of ships and tobacco in all states of production. Gracing the top of the edifice was the winged figure of Fame blowing a trumpet. Inside the building's first floor, over 110 horses worked to power the factory's 77 molinos (mills) to ground tobacco into snuff. While only men worked on this main floor, upstairs in a large hall that ran nearly the entire length of the building, mostly women worked rolling cigars. In all, approximately 1,400 people including 1,300 day workers oversaw the processing of the never-ending influx of tobacco from Cuba and to a much lesser extent, the New World. ${ }^{166}$

The process of growing and curing tobacco was a complicated one, delicate at every step. Yet, the methods used by eighteenth and nineteenth-century tobacco farmers described above differed little from those used as early as the sixteenth and seventeenth centuries. At that time, tobacco was sown by mixing the seeds with six parts sand or ash. After a period of being covered in the seed bed, the plants were transplanted up to the "ojo" (eye) or up to the lowest leaves when the seedlings had six leaves. When mature, the plant was cut at the bottom and left all day in the sun to dry, then taken to the curing

166 - Warren, Vagamundo, 150-52; Fermín Arana de Varaflora, Compendio historico descriptivo de la muy noble y muy leal ciudad de Sevilla metropoli de Andalucía formabalo don Fermín Arana de Varaflora, natural y vecino de dicha Ciudad (1789), 82-83; José M. Rodríguez Gordillo, Un archivo para la historia del tabaco (Madrid: Jacaryan, 1984), 23-49. Arana de Varaflora noted that 21 of machines were powered by 6 molinos each, while there were 6 of 4 each, 2 of 2 mills each, and 48 additional ones. 
house. ${ }^{167}$ These similarity of these practices, repeated in almost the same way in areas as disparate as Cuba, central Virginia, and Venezuela demonstrated the continuity in tobacco growing and cultivation over time. A tobacco farmer's knowledge was as much about experience, patience, and skill as it was passed on from one generation to the next.

167 - José Pérez Vidal, España en la historia del tabaco (Madrid: Imprenta Samarán, 1959), 207-08. 


\section{Chapter 3:}

\section{Tobacco's Chosen People}

Tobacco was described by Fernando Ortiz as "one of the most difficult crops in the world to cultivate," and raising and curing tobacco was a complex and delicate operation. ${ }^{168}$ A farmer's success in bringing his crop to market ultimately rested in his knowledge of the plant and its intricacies. Knowing when to remove the flower buds in order to produce a larger leaf, protecting the plants from pests such as the voracious hornworm, and determining when the tobacco had properly cured were intrinsic skills that led Virginia planter Landon Carter to comment, "Tobacco planting I see is an art to be learned not more by practice than by reasoning justly upon things."'169 For its growers, however, tobacco was more than just an agricultural pursuit, and instead "touched every aspect of their existence," creating a mentality, a social identity, and a culture based on tobacco in which a man's personal reputation was closely tied to his ability to raise a large and high quality tobacco crop. ${ }^{170}$

The characteristic terminology for a tobacco farm, vega, was not regularly used as a separate entity in Cuba during the first half of the eighteenth century, and thus, it is

168. Ortiz, Cuban Counterpoint, 27.

169 . Paul G.E. Clemens, The Atlantic Economy and Colonial Maryland's Eastern Shore: From Tobacco to Grain (Ithaca: Cornell University Press, 1980), 184.

170. Breen, Tobacco Culture, 22-23, 41; Ortiz, Cuban Counterpoint, 40. For a similar mentality for sugar see Michel-Rolph Trouillot, "Motion in the System: Coffee, Color and Slavery in Eighteenth-Century Saint-Domingue," Review 5, no. 3 (Winter 1982): 342 . 
difficult to determine the exact number of tobacco farms during this period. The terms vega and estancia, or cattle ranch, were used interchangeably, and even today they are not considered "independent economic and legal entities."171 Even later in the eighteenth century, when vegas were specified, they were often listed along with estancias. The island's 1778 census included an unknown number of tobacco farms within the 3,958 estancias reported, while the 1792 census ordered by Captain General Luis de las Casas noted a combined total of 6,134 cattle and tobacco farms. ${ }^{172}$ In 1811, Cuba's 5,534 vegas covered approximately 371,560 caballerias, or nearly 12.4 million acres representing 44 percent of the island's total land area. ${ }^{173}$ By early January of 1812 , as the end of the monopoly loomed near, tobacco cultivation and the number of farms dedicated to the plant decreased. A count of those involved in the island's tobacco industry reported 3,996 vegas and 8,775 people engaged in tobacco cultivation. The majority of these tobacco farms, 80 percent, were located in the central and eastern parts of the island.

171. Iglesias, La estructura agrária en el occidente de Cuba 1700-1750, 14-15.

172. Diego José Navarro, "Estracto del padron general de havitantes de la isla de Cuba, correspondiente a fin de Diciembre de 1778," 31 December 1788, Havana, Revista de la Biblioteca Nacional José Martí 29 (septiembre - diciembre 1987), 25; "De los habitantes de la isla de Cuba, formado en el mes de Diciembre de mil setecientos noventa y dos, de órden del Escelentísimo Sr. D. Luis de las Casas y Aragorri, Gobernador de la Habana, y Capitan general en dicha Isla, sin comprender en él las tropas veteranas, Marina, presidiarios, ni esclavos del Rey, espesándose el número de los templos, hospitalos, colegios, y las haciendas del campo," December 1792, Box 8, Number 10, José Escoto Collection, Houghton Library, Harvard University, Boston, Massachussetts.

173. Ramón de la Sagra, Historia economico-politica y estadistica de la Isla de Cuba ó sea de sus progresos en la población, la agricultura, el comercio y las rentas (Habana: Imprenta de las Viudas de Arazoza y Soler, 1831), 119; Robert C. West and John P. Augelli, Middle America: Its Land and Peoples, 3rd ed. (Englewood Cliffs, New Jersey: Prentice Hall, 1989), 130. 
Local officials were keenly aware of the decrease in production and they opined that if additional lands available for tobacco cultivation were opened, a total of 20,000 vegas tended by 40,000 farmers was possible. ${ }^{174}$

Several areas of the island were centers of tobacco cultivation. The region most closely associated with tobacco was Filipinas, known today as Pinar del Río, and addressed in detail in a separate chapter. ${ }^{175}$ Another location with strong ties to tobacco was the villa of San Julían de los Güines. Previously described in the historiography as the epicenter of eighteenth-century sugar expansion, a reevaluation shows that Güines was an area devoted to tobacco production. ${ }^{176}$ In just four years, 1768 to 1771 , the number of vegueros in Güines increased more than 65 percent, from 133 to 202. Between 1771 and 1774 , the overall number of vegas dropped slightly from 279 to 248 , but more people were working in the area's tobacco fields, 682, up from 586 workers in 1771.177

174. Juan Gregorio Nuñez and José Gonzalez, "Plan demostrativo de todas las tierras que acutalmente hay destinados al cultivo de tabacos en cada partido de la isla de Cuba: con expresion de sus calidades y las mejoras de que son susceptibles: á fin de llenar el articulo 15 de la real órden instructiva al Director general nombrado en 12 de octubre de 1803, para la visita reforma y arreglo de la Factoria; y el encargo del actual Superintendente en 9 de enero de 1812," 31 May 1817, Real Factoría de Tabacos, La Habana, legajo 2019, SD, AGI; Guerra y Sánchez, Pérez Cabrera, Remos, and Santovenia, Ilustración libertad de comercio (desde 1790 hasta 1837), 346.

175 . The area was known alternately as "Filipina," "Filipinas," and "Nueva Filipinas." Similiarly, Pinar del Río was usually known as "Pinal del Río" until the former won out. See Santovenia, Pinar del Rio, 93-94.

176. Moreno Fraginals, The Sugarmill, 19-20.

177. Francisco Gama, "Tazmia General de los Cujes de tabaco qe cada Labrador ha confezado haber cogido en este Partido de los Güines y Sn Pedro de las Carreras este año de 1768," 14 April 1768, Güines, legajo 1090, PC, AGI; Francisco Gama, "Tazmia de los cujes de tabaco del Partido de Guines, respectiba a la cosecha de este año de 1771," 
Despite a minor decrease in the number of farms, Güines remained committed to tobacco cultivation, so much so that in 1775,87 percent of its residents lived on vegas, which occupied one-fifth of the villa's total land area. Tobacco's influence on Güines only grew stronger with the 1786 reorganization of the area in an effort to focus specifically on tobacco. The plan was a success, and by late June of 1792 the number of vegas had increased to 590, and exceeded 600 in another four years. ${ }^{178}$ As late as July 5, 1809, tobacco remained a strong agricultural presence with 60 tobacco farms, as compared to just 5 sugar plantations, and 8 to 10 coffee estates. ${ }^{179}$

Filipinas and Güines, however, were just two of many areas on the island where tobacco cultivation played a significant role in the lives of those in the local community. After the end of the tobacco monopoly in 1817 , the industry expanded as both the number of Cuba's tobacco farms and the workers tending them increased. In just the first ten years after the monopoly was abolished, the number of vegas rose by about 40 percent to 5,534. One-quarter of these were in Cuba's central department, while 29 percent were

15 May 1771, Güines, legajo 1090, PC, AGI; Francisco Gama, "Tazmia que comprehende el numero de Vegas, operarios y cujes de Tavacos qe ha confesado tener cada Labrador con destino á Seco en el Partido de los Guines, perteneciente á la Cosecha de mil setecientos setenta y quatro," 8 June 1774, Güines, legajo 1195, PC, AGI.

178. Leví Marrero, Azucar, ilustración y conciencia (1763-1868)(I), vol. 9 of Cuba: economía y sociedad (Madrid: Editorial Playor, 1983), 217; "Partido de San Julian de los Güines, Resumen gral del numero de ganados de todas especies, que tienen sus Haciendas, y de los Caros y Carretas que hay en cada una de ellas," 26 June 1792, Güines, legajo 1471, PC, AGI; Johnson, Sherry, Social Transformation, 54-55.

179. Manuel Cuadrado Melo, Obispado de la Habana su historia a traves de los siglos, vol. 1, part 1A (1970), 74-1. 
located in the eastern department. ${ }^{180}$ As the nineteenth century progressed, tobacco cultivation only expanded throughout Cuba, particularly in the central and eastern parts of the island. There were 9,482 tobacco farms throughout Cuba by mid-century, with nearly 60 percent located in the eastern part of the island from Las Tunas to Baracoa. Indeed, in 1861, there were 750 more vegas in the Santiago de Cuba jurisdiction than there were in Pinar del Río. By 1899, even centrally-located Santa Clara boasted more vegas $(15,585)$ than Pinar del Río $(14,928) .181$

The tobacco vega was an important rural fixture in late colonial Cuba, not only for the crop it produced, but also as home to thousands of residents throughout the countryside. By 1846 , approximately 17 percent, or 71,319, of Cuba's rural community lived on vegas. Even in distant Oriente, not usually associated with tobacco cultivation, just over 20 percent of the total rural population called a tobacco farm home. In the eastern jurisdictions (partidos) of Guisa, Sagua, and Mayarí Abajo, more than 75 percent of rural residents lived on a vega. ${ }^{182}$ When the next census was taken in 1862 , over

180. Guerra y Sánchez, Sugar and Society in the Caribbean, 49; Guerra y Sánchez, Pérez Cabrera, Remos, and Santovenia, Ilustración libertad de comercio (desde 1790 hasta 1837), 178.

181. Jacobo de la Pezuela, "Estado general de la produccion agricola y riqueza rural de la isla correspondiente al año de 1861," in Diccionario geográfico, estadistico, histórico de la Isla de Cuba, vol. 1 (Madrid: Imprenta del Establecimiento de Mallado, 1863), 38-39; Jean Stubbs, Tabaco en la periferia (La Habana: Editorial de Ciencias Sociales, 1989), 211.

182. Levi Marrero, Azucar, ilustración y conciencia (1763-1868) (III), vol. 11 of Cuba: economía y sociedad, Madrid: Editorial Playor, 1984, 60-61. In an earlier volume of this same series, Marrero contends that just 4.7 percent of Cuba's rural population resided on vegas in 1846. See Levi Marrero, Azucar, ilustración y conciencia (17631868) (I), vol. 9 of Cuba: economía y sociedad, 207. Based on calculations of both the 
108,000 residents including 75,000 rural whites, and 17,675 slaves lived on tobacco

farms throughout the island, while nearly one-fifth of eastern Cuba's free black

population lived on vegas. ${ }^{183}$

\section{Tobacco in their Blood}

Who were these people who were so dominant an influence in colonial Cuba's

agriculture and economy? In a poem, nineteenth-century planter, slavery critic, and

supporter of annexation to the United States, Domingo del Monte y Aponte described the

Cuban veguero as

Tranquilo cultivando / Mis vegas adoradas / Del gran

Cuyaguateje en la ribera / Mis horas van pasando, / Cual

pasan sosegadas / Las ondas de mi río en su carrera. / Y la

discordia fiera / No turba mi reposo; / Ni la cendrada plata

/El sueño me rebata, / Ni lo ageno jamás quise envidioso; /

Que en viendo mi hoja amada / Se alegra al punto mi vejez

cansada. ${ }^{184}$

actual population numbers and corresponding percentages found in volume 11 , however, the first amount (about 17 percent) cited in volume 11 appears to be the more accurate one.

183 . Scott, Rebecca J., Slave Emancipation in Cuba, 8, 12.

184. Antonio de Gordon y de Acosta, El tabaco en Cuba: Apuntes para su historia (La Habana: Tipografia "La Propaganda Literatura", 1897), 17-18. For Domingo del Monte y Aponte, see Johnson, Sherry, Social Transformation, 179; Louis A. Pérez, Jr., Cuba: Between Reform and Revolution, 2nd ed. (New York: Oxford University Press, 1995), 110. The Cuyaguateje is a river located in Pinar del Rio, an area which is addressed in greater detail in a subsequent chapter. 


\section{The Historiographical Veguero: Poor, White and Canary Islander}

Fernando Ortiz's poetic description of the Cuban tobacco farmer crafted in the 1930s in large part is responsible for the creation of one of the most lasting images of the veguero. His depiction reveals his own sense of pride in these farmers and a romanticized longing for a past that Ortiz believed was slowly disappearing. 185

Throughout his seminal work, Cuban Counterpoint, the tobacco farmer was contrasted with the sugar planter:

The tobacco-grower was a simple countryman who required no machinery beyond a few tools and who could supply his own needs from the limited resources of the local general store. Whereas the sugar-planter acquired wealth, titles of nobility, government posts, refinement, and, at times, a desire for progress, the veguero was always a small, rustic, rule-of-thumb farmer. While the planter gave Cuba railroads before they were introduced to Spain, and Havana had its flourishing theater presenting plays and operas as good as those of Madrid, the veguero still rode his horse through the woods and found his entertainment in cockfights, songs, and country dancing. ${ }^{186}$

It is this image of the veguero as a poor, white and often a Canary Islander, small-scale farmer that is repeated throughout most of the existing historiography, yet diversity was the rule as will be shown later in this chapter. ${ }^{187}$

185. Ortiz, Cuban Counterpoint, 53.

186 . Mbid., 65.

187. A sampling of works which continue this thesis includes Ramiro Guerra y Sánchez, José M. Pérez Cabrera, Juan J. Remos, and Emeterio S. Santovenia, Historia de la nación cubana, vols. 2-3, (La Habana: Editorial Historia de la Nación Cubana, 1952); Knight, Slave Society in Cuba, 65; Moreno Fraginals, El ingenio, 21-22; Kuethe and Inglis, "Absolutism and the Enlightened Reform," 134. For a more detailed discussion of the historiography, see Chapter 1. 
The characterization of Cuba's tobacco growers as whites, or more specifically as

Canary Islanders, is another common component in the existing historiography. ${ }^{188} \mathrm{~A}$ sizable population of Canary Islanders, also known as isleños, lived in Cuba during the colonial period, and their association with agricultural pursuits, especially tobacco, led to the evolution of a historiography that makes a logical connection between tobacco and isleños. From the earliest days of Cuba's colonization, Canary Islanders came to Cuba and made their mark on the island's population. Between 1585 and 1645, approximately one-quarter of immigrants entering Havana were Canary Islanders. ${ }^{189}$ Isleño immigration received a significant push with a 1681 royal cedula that directed ship captains leaving for the West Indies from the Canary Islands to take five emigrating families for each 100 tons of cargo carried. In return, the captains were exempt from customs duties for ten years. ${ }^{190}$ By 1693, over 800 isleño families called the area around Havana home. Other methods used to encourage Canary Islanders to come to the New World included free passage to the West Indies, an exemption from taxes, and a cash subsidy of 50 pesos per

188 . Ortiz, Cuban Counterpoint, 57, 59-60; Guerra y Sánchez, Pérez Cabrera, Remos, and Santovenia, Ilustración libertad de comercio (desde 1790 hasta 1837), 50, 52-53; Santovenia, Pinar del Río, 91.

189 . Manuel Hernández González, Canarias: la emigración (La Laguna, Tenerife: Impecan, 1995), 20. Canary Islanders were not always welcomed, as real cedulas in 1574 and 1599 which prohibited isleño immigration to the Indies demonstrate. Antonio M. Macías Hernández, La migración canaria, 1500-1980 (Colombres, Spain: Ediciones Júcar, 1992), 41.

190 . James J. Parsons, Hispanic Lands and Peoples: Selected Writings of James J. Parsons, William M. Denevan, Dellplain Latin American Studies (Boulder, CO: Westview Press, 1989), 400, 403. 
family. ${ }^{191}$ Historians contend that for the Canary Islanders that came to Cuba the opportunity to grow tobacco was a key attraction, and the isleños, long considered expert agriculturists, quickly became known as expert tobacco farmers. ${ }^{192}$ Furthering this association, the word commonly used to describe a tobacco farm, "vega," originated in the Canary Islands, and Canary Islanders resided in the villages surrounding Havana and Güines, areas known for their tobacco cultivation. ${ }^{193}$

Yet, the belief that tobacco production was dominated by Canary Islanders is simplistic at best and erroneous at worst. By the late eighteenth century, the presence of isleños in Cuba's tobacco fields had diminished considerably. In fact, for the period under study, few Canary Islander tobacco farmers are found in period documents and

191 . Ibid., 403.

192 . Riverend, Historia económica de Cuba, 56; McNeill, Atlantic Empires of France and Spain, 35; Julio Hernández García, La emigración canaria contemporánea (Siglo XIX) (Las Palmas: Ediciones del Cabildo Insular de Gran Canaria, 1987), 32-33; Macías Hernández, La migración canaria, 1500-1980, 84-85, 124-25. Cultivation of tobacco in the Canary Islands remained low until the late-eighteenth- and earlynineteenth-centuries when attempts were made to diversify the archipelago's agriculture. Today, tobacco, although only of moderate quality, is grown on La Palma and Gran Canaria. Enrique Romeu Palazuelos, Leopoldo de la Rosa Olivera, and Antonio Miguel Bernal Rodríguez, Las islas canarias (Madrid: Espasa-Calpe, 1981), 22.

193 . Antonio Lorenzo, Marcial Morera, and Gonzalo Ortega, Diccionario de canarismos (La Laguna: Francisco Lemus, 1995), 343; Johnson, Sherry, Social Transformation, 69-70. "Vega" specifically describes a plot of land along the banks of a river, however the term is given to any land, irregardless of its location, dedicated to the cultivation of tobacco. The more accurate term for land where tobacco is grown is "tabacal," or tobacco farm. See Ortiz, Cuban Counterpoint, 30-31; de la Sagra, Historia fisica, politica y natural de la isla de Cuba, 80 . The presence of former members of the Cuban military, many of whom were recruits from the Canary Islands, in the countryside is also well documented. See Johnson, Sherry, Social Transformation, 49-70; Kuethe, Cuba, 1753-1815, 89,95, 129. Canary Islanders also founded the towns of Matanzas and Santiago de las Vegas. Macías Hernández, La migración canaria, 1500-1980, 76. 
tazmias. Of the more than 60 tazmias gathered for this study, only 13 individuals out of hundreds listed were described as isleños. Although many were centered near Havana or in the central part of the island, Canary Islanders lived in all parts of Cuba. Seven of the isleño tobacco growers lived in the areas surrounding Trinidad, Santa Clara, and Puerto Príncipe, while four lived around Govea or Cano, just outside of Havana, and only one individual resided in far western Cuba, the area most closely associated with tobacco. Nearly all of the isleño vegueros, or eleven men for whom the data is available, worked alone or with one additional person on their tobacco farms. In only two instances did an isleño-run vega employ between three and five workers, a figure that included the owner. Together, these 13 isleño farmers produced approximately 8,325 sticks of tobacco, ranging from a low of 100 to a high of 1,600 cujes. 194

194. Manuel Ramos, "Tazmia de los Tabacos del Partido de la Canoa, Respectiva a las Cosechas de 1770," [no date], Canoa, legajo 1094, PC, AGI; Joaquín de Sola, "Tazmia de los tavacos de los Partidos de Vegas correspondientes [unclear] de la Villa del Puerto del Príncipe respectiva a la cosecha de este año de mil setecientos y setenta," 25 May 1770, Puerto Príncipe, legajo 1085, PC, AGI; Vicente del Castillo, "Tazmia gral de los tavacos qe aproducido el partido del Cano en que se comprehende Sn Antonio Sierresita de San Pedro y anafe, Respectiva a la cosecha del año de 1772 con notisia del no de Vegas sus dueños y operarios y porzion de cujes," 3 May 1772, Cano, legajo 1196, PC, AGI; Simón de la Cruz, "Tazmia de los tavacos de los Partidos de Govea, Aguas Verdes, Buenaventura, el Sor de la Salud, Batabano y sus Dependencias, y Sn Antonio, con expresión del numero de Vegas y conucos, operarios q. en ellas travajan inclusos los dueños, y cuxes de Tavaco qe cada uno ha recogido en la cosecha del Presente año de 1773, a saver," 7 May 1773, Govea, legajo 1196, PC, AGI; Vicente del Castillo, "Tazmia de los tavacos de los Partidos que se comprehenden en la diputación de Capn Dn Vicente del Castillo respectiva a la cosecha de 1774," 10 July 1774, Partido del Cano, legajo 1192, PC, AGI; Joaquín de Sola, "Tazmia de los tabacos de los Partidos correspondientes a la Factoria de la Villa de Santa María de Puerto de Príncipe, respecitva a la cosecha de este año de mil seticientos setenta y siete," 24 March 1777, Puerto Príncipe, legajo 1180, PC, AGI; Fernando Muñoz, "Tasmia gral que manifiesta las Vegas que comprehende esta Jurisdon de mi cargo: Yd el numo de operars y matas de tavaco que hay sembradas en cada una executada por Dn Fernando Muñoz Ministro Factor de este Ramo el la Ciud de 
Among the isleño vegueros growing tobacco in central Cuba between 1777 and

1783, production varied greatly. Francisco el isleño tended just 2,000 plants in the

Partido de Samaraguan near Puerto Príncipe, while close to Trinidad, Antonio's Rio de

Caracusey-area vega contained 9,000 plants, and Bartholo cared for 10,000 tobacco plants

near the Rio de Animado. ${ }^{195}$ If additional workers were available, tending larger crops

were possible as the examples of Salvador and Manuel, Canary Islanders who owned

Trind para remitir a la Ciud de la Havana al Exmo Señor Govr y Capn Gral," 7 July 1781, Trinidad, legajo 1313, PC, AGI; Gabriel de Mier, "Tazmia correspondte a los Partidos de la Buelta de Abajo en que comprehende el numero de Vegas, sus Dueños, operarios que las cultivan, y los Cujes que cada uno tiene dentro de sus Casas a saver," 15 June 1782, Filipina, legajo 1317, PC, AGI; Fernando Muñoz, "Notisia qe manifiesta el numero de vegas qe comprehende esta Jurisdicon ydem de operarios y matas, qe en cada una pueden sembrarse, guardando el orden de distana prevenido: executada pr Dn Ferando Muñoz Mro Factor de dho ramo de tavcos en esta ciud. de Trinidad, sus Partidos, pa remitir a la de la Havana, al Sor Govor y Capn Gral de dha ciud. de la Havana é Ysla de Cuba a saver," 2 April 1783, Trinidad, legajo 1349, PC, AGI. These figures are based on formulas found in José de Aguilar y Blanco, "Tazmia qe manifiesta los Tavacos sembrados en el presente año por los Labradores de los Partidos de la Jurisdicción de esta Villa, a saver," 20 March 1782, Sancti Spirítus, legajo 1313, PC, AGI; [name illegible], "Relasion de las Vegas que se han Cultivado tavacos, en el presente año, el el Río de Cuiaguatexe con individualidad de los sujetos, cujes, y manojos que pueden producir," 30 May 1771, Cuiaguatexe [sic], legajo 1096, PC, AGI; and "Autos sobre el mal uso que hacen los vegueros de Chambas y Tatibunico de sus cosechas de tabaco," 22 November 1798, San Juan de Remedios, numero 7, legajo 1003, IGH, ANC. These documents allow calculations of the amount of tobacco produced in cujes when only the number of plants is given. Period notes state that each plant has 8 usuable leaves, and 100 leaves comprise a manojo. A total of 1.5 cujes are needed to produce a single manojo. When the names from the tazmias in western Cuba are cross-referenced with the local censuses which specify the birthplace of the residents, additional Canary Islanders were found. However, the majority of those growing tobacco in Filipinas were not Canary Islanders. See Chapter 4 for more details.

195 . Joaquin de Sola, "Tazmia...Puerto de Príncipe," 24 March 1777, Puerto Príncipe, legajo 1180, PC, AGI; Fernando Muñoz, "Tasmia," 7 June 1781, Trinidad, legajo 1313, PC, AGI; Fernando Muñoz, "Notisia... el numero de vegas," 2 April 1783, Trinidad, legajo 1349, PC, AGI. 
vegas near Puerto Príncipe in 1770 , demonstrate. Manuel's vega was worked by two people, most likely including Manuel himself, and contained 25,000 plants which could be expected to result in approximately 1,600 sticks of tobacco at harvest time. In contrast, Salvador labored alone on his Partido de Saramaguacan al Norte vega, and tended a mere 6,000 tobacco plants, enough tobacco to produce about 384 cujes. ${ }^{196} \mathrm{~A}$ larger labor force, however, did not guarantee a proportional increase in tobacco production. José worked alone on his San Pedro-area tobacco farm located just southwest of Havana and produced 500 sticks of tobacco. Conversely, although four additional people labored on the vega near Canoa owned by Sebastian el isleño, they produced only 1,000 cujes. ${ }^{197}$ Nineteenth-century manuals for Cuban tobacco farmers indicate that a single veguero was capable of tending between 10,000 and 12,500 tobacco plants, but it is uncertain whether monopoly restrictions, land quality, the amount of land available to farm, personal preferences, or a combination of these factors governed the decisions of these isleño vegueros. ${ }^{198}$

Notary records, particularly wills, provide more detailed information about the few individuals described as both tobacco farmers and Canary Islanders. On May 9, 1776, just two days before he died, José Antonio González dictated his will before notary

196 . Joaquin de Sola, “Tazmia...Puerto de Príncipe," 25 May 1770, Puerto Príncipe, legajo 1095, PC, AGI.

197 . Manuel Ramos, “Tazmia Partido del la Canoa," [no date], Canoa, legajo 1094, PC, AGI; Vicente del Castillo, "Tazmia de los tavacos," 10 July 1774, Partido del Cano, legajo 1192, PC, AGI.

198 . Nobiatur, El veguero practico y cientifico, 15; Un Amigo del Pais, Memoria sobre el tabaco de la isla de Cuba, 25; de Paula Arias, El veguero de Vuelta Abajo, 22. 
Carlos Ximénez in Santiago de las Vegas. The legitimate son of Juan González and Leonarda Falcón, González was born in the Canary Islands. Among the possessions he listed was a vega located on property belonging to don José Nicolás Escalera and approximately 1,200 sticks of tobacco hanging in a barn there. Two African-born slaves, José María Carabali and José Antonio Mina who perhaps were used as labor on the vega, were also listed among González's assets. ${ }^{199}$ Having acquired access to both land and slaves in the time that he resided in Cuba, González clearly does not match the image of a poverty-stricken tobacco farmer presented by Ortiz and others.

Not until the nineteenth-century did the largest wave of Canary Island immigration begin. In 1817, the final year of the Cuban tobacco monopoly, Spain embarked on an effort to increase the island's white population and only after that year did isleños make a significant demographic impact on Cuban society. Openly advertising for white immigrants, the crown welcomed not just Spaniards and Canary Islanders, but any Roman Catholic European "subjects of states with whom we are at pace and amity."200 After residing in Cuba full-time for a period of five years, foreign immigrants would be granted the same rights and privileges received by natural-born subjects. ${ }^{201}$

199 . José Antonio González, testimonio, 9 May 1776, Santiago de las Vegas, Escribania de Gobierno (hereafter EG), Carlos Ximénez 1776-1777, page 43-48, ANC.

200 . "Real Cedula de 21 de octubre de 1817 , sobre aumentar la poblacion blanca de la isla de Cuba." Habana: Oficina de Arazoa y Soler, 1818. Section 18, Folder 5 of 10, Spanish Consulado at Norfolk (hereafter SC), Virginia Historical Society, Richmond, Virginia (hereafter VHS).

201. Ibid. A later royal order offered even more enticing terms to foreign immigrants including the possibility of free land. See "Real orden que espidieron las Córtes Ordinarias en 27 de junio de 1821, y sancionó S.M. en 12 de marzo de 1822, sobre 
Although the process was a slow one, Spain's goal of counteracting the racial imbalance between whites and blacks in Cuba was reached in 1859 when whites again comprised the majority of Cuba's population. Isleños were responsible for a significant portion of this increased white population. Over a period of fifteen years, from 1835 to 1850 , 15,700 Canary Islanders immigrated to Cuba. Approximately 42 percent of all Spanishborn residents, or 48,552 people, were natives of the Canary Islands according to the 1862 Cuban census. ${ }^{202}$ Based on the research conducted in this study, the impact of Canary Islanders, particularly those of recent immigrants still describing themselves as isleños, on Cuba's tobacco industry appears to be minimal. The few individuals found in the tazmias and described as Canary Islanders does not support the argument forwarded by so many historians that the tobacco industry and the isleño population of Cuba were intimately tied.

el aumento de la poblacion blanca de estangeros en las provincias españolas ultramarinas." Habana: Imprenta Fraternal de los Diaz de Castro, 1822. Section 18, Folder 7 of $10, \mathrm{SC}$, VHS.

202 . Susan Schroeder, Cuba: A Handbook of Historical Statistics (Boston: G.K. Hall, 1982), 106; Macías Hernández, La migración canaria, 1500-1980, 96; Conde Armildez de Toledo, "Noticias estadisticas de la Isla de Cuba en 1862, dispuestas y publicadas por el centro de estadistica" (Habana: Imprenta del Gobierno, Capitania General y Real Hacienda por S.M., 1864), 46. For a history of Canary Island migration to the Americas, see Gilbert Din, The Canary Islanders of Louisiana (Baton Rouge and London: Louisiana State University Press, 1988); Carlos Esteban Deive, Las emigraciones canarias a Santo Domingo: Siglos XVII y XVIII (Santo Domingo: Fundación Cultural Dominicana, 1991); Hernández González, Manuel, Canarias: la emigración; Manuel Hernández González, Los canarios en la Venezuela colonial (16701810) (Tenerife, Canary Islands: Taller de Historia, 1999); Manuel Vicente Hernández González, La colonización de la frontera dominicana 1680-1795 (Santo Domingo: Editora Búho, 2006). 
Centuries of immigration from the Canary Islands to Cuba described above only enhances the challenge of this task. Those whose Canary Island origins were at least one generation removed were most likely integrated into society as Cubans rather than as isleños and therefore no distinction would not be made to describe them by an ethnic identifier. None of the vegueros clearly described as isleños are listed as such in subsequent tazmias. This indicates that perhaps these individuals were recent immigrants and by the time of the next tazmia had become sufficiently integrated into the community to be known simply by their surnames rather than a descriptive modifier. While some colonial Cuban tobacco farmers did fall into these categories, the existing historiography incorrectly describes the Cuban veguero as exclusively poor, white, Canary Islander, creating an overly simplistic, erroneous view of these important agricultural producers.

Of all the generalities proposed by Ortiz, poverty may have been the most accurate, often plaguing Cuba's late-eighteenth- and early-nineteenth-century tobacco farmers. When officials threatened to fine vegueros east of Havana 50 ducados for failing to clear the roads with axe and machete within the ordered two months, one local official indicated that it had little effect as the farmers simply did not have the money to pay. ${ }^{203}$ The monopoly's practices often contributed to the economic hardships endured by many of Cuban tobacco farmers who routinely complained that they were not paid fair prices for their tobacco, or were not paid upon delivery of their crop. ${ }^{204}$ When vegueros

203 . Francisco Nates to Marqués de la Torre, 24 April 1772, Havana, legajo 1192, PC, AGI.

204 . Felipe Bellos to Antonio María Bucareli, 24 August 1766, Sancti Spiritus, document 10, legajo 1087, PC, AGI; Martín de Asanza to Marqués de la Torre, 7 July 
in the Partido de Govea requested that the prices paid for their tobacco be raised, the monopoly refused because, as Minister of the Indies Julian de Arriaga conceded in a letter to Captain General Bucareli, "there was no just motive for it."205 By the second decade of the nineteenth century, little had changed, leading one Cuban to contend that the tobacco farmers were not paid but a third of what their crop was worth. ${ }^{206}$ Not only were prices unfair, according to the farmers' estimation, the monopoly sometimes failed to pay for tobacco that already had been delivered. In 1772, a resident of Bayamo complained that when the vegueros presented their tobacco they were often given a paper by monopoly representatives stating that there was no money to pay them. ${ }^{207}$ Despite these criticisms, little was done to alleviate the situation. It was suggested in late 1813 that the government require the vegueros to turn in their tobacco to the monopoly even if the farmers were not paid at all.208

1774, Bayamo, legajo 1179, PC, AGI; Juan Antonio Ayans de Ureta to Pascual de Cisneros and Marqúes de la Torre, 4 September 1774, Santiago de Cuba, legajo 1142, PC, AGI; Alejandro Ramírez to Secretario de Estado y del Despachado de Hacienda de España, 10 October 1817, Havana, legajo 2019, SD, AGI.

205 . Julian de Arriaga to Antonio María Bucareli, letter, 22 September 1770, San Ildefonso, folio 119, legajo 1134, PC, AGI.

206. Pedro Suarez de Urbina to Secretario de Estado y Despacho de Hacienda, 14 December 1813, Santiago de Cuba, legajo 2001, SD, AGI.

207 . Marqúes de la Torre to José de Albanado, 20 April 1772, Havana, folio 310311, legajo 1179, PC, AGI.

208 . Pedro Suarez de Urbina to Intendente del Ramo de Tabaco, 18 October 1813, Santiago de Cuba, legajo 2001, SD, AGI. 
Royal authorities on the island, including Cuba's highest-ranking official, acknowledged the difficulties inflicted on the farmers by these practices. In 1774 , the Marqués de la Torre authorized Bayamo's factor de tabacos, Martín de Asanza, to pay the vegueros for their crop. De Asanza should find money to pay the farmers, the captain general stated, from whatever source possible in order to "satisfy in some way the vegueros of this Jurisdiction, who only with the product of their crops, can alleviate the misery in which they suffer." ${ }^{209}$ By the mid-1810s, a few officials within the Cuban tobacco monopoly itself conceded that promptly paying the tobacco growers for their crop provided a positive stimulus to the industry, 210

\section{The Lost Historical Vegueros: The Slave Vegueros}

Royal officials recognized slaves as an important source of labor for the island's tobacco industry. Between 1740 and 1760, the Real Compañia Mercantil de la Habana (Royal Mercantile Company of Havana) sold nearly 5,000 slaves "at an average price of 144 pesos," with the vast majority (almost 4,000) sold on credit or paid for with

209 . Marqués de la Torre to Martín de Asanza, 4 July 1774, Havana, legajo 1179 , PC, AGI. The letter reads: "Me hago cargo de la necesidad que obliga a UM a solicitar el permiso de buscar en ese vencindario algunas cantidades de dinero, librandolas contra la Tesoreria del Ramo de Tabaco de esta ciudad, para contentan en alguna manera a los vegueros de esa Juirsdiccion que solo con el producto de sus cosechas pueden aliviar las miserias que padacen; y sobre este particular se arreglara UM a lo que le perviniere el Administrador General de la Factoria."

210. Rafael Gómez Robaud to Francisco de Saavedra, 9 January 1810, Havana, legajo 2001, SD, AGI. 
tobacco. 211 In 1750 , the crown authorized the sale of up to 500 slaves at the price of 300 pesos each in cash or tobacco in the hopes of increasing tobacco production. Cuba's governor, Francisco Cagigal de la Vega countered that 1,500 or more were needed for Havana's districts alone. ${ }^{212} \mathrm{~A}$ decrease in tobacco production led the governor of Santiago de Cuba, Alonso Arcos y Moreno, to suggest in 1752 that the introduction of black labor would result in a larger tobacco crop. ${ }^{213}$ Cagigal de la Vega agreed, stating that without slave labor it would be impossible to fully enjoy "the abundance of this fruit." 214 In 1764, the local head of the tobacco monopoly in Santiago de Cuba, Mateo Echavarria, requested "algunos negros bozales" to assist in tobacco cultivation. ${ }^{215}$ Even Spain's King Charles III realized the value of slave labor in the island's tobacco industry, approving the purchase of twenty slaves to assist in the work of the royal monopoly.216

211 . Hubert H.S. Aimes, A History of Slavery in Cuba, 1511-1868 (New York: Octagon Books, 1967), 23-24. Tobacco became just one component of a triangular trade in which Cuban tobacco was carried to Spain, exhanged for merchandise needed in the slave trade, and taken to Africa where slaves were procurred and later taken back to the island. Aimes, Slavery in Cuba, 26-27.

212. Boletin del Archivo Nacional de Cuba, vol. 14 (1915), 4 in Marrero, Del monopolio hacia la libertad comercial (1701-1763) (II), vol. 7 of Cuba: economía y sociedad, 68; Aimes, Slavery in Cuba, 27.

213. Alonso Arcos y Moreno to Francisco Cagigal de la Vega, 13 December 1752, Santiago, legajo 6, CG, ANC.

214. Francsco Cagigal de la Vega to Alonso Arcos y Moreno, 10 March 1753, Havana, legajo 6, CG, ANC.

215 . Luis de Echevarria to Conde de Ricla, 16 April 1764, Santiago de Cuba, orden 5, legajo 6, CG, ANC. 
Despite these measures, not enough slaves were available to. fulfill the ever growing demand. Additional slaves were needed to work in agricultural pursuits, "especially tobacco," Captain General Marqués de la Torre complained to Spain in 1773.217 One year later, local officials in Cuba continued to petition Havana for more slaves. Bayamo, for example, wanted 600 or 700 slaves to help with planting. ${ }^{218}$ The prompt payment of the vegueros and distribution of slaves would contribute to a significant increase in tobacco production, the governor acknowledged to the manager of the Bayamo's monopoly. The funds were simply not available for either, de la Torre conceded.219

Between its founding in 1740 and 1760, the Real Compañia de Comercio de La Habana, the "mixed state and private enterprise" which held the exclusive right over all trade and commerce on the island, sold nearly 5,000 slaves in Cuba with the majority paid by credit or in tobacco. ${ }^{220}$ Not only did the Compañia provide the tobacco farmers with a labor force, but it also engaged in a triangular trade involving tobacco and slaves.

216. Julian de Arriaga to Antonio María de Bucareli, 22 September 1769, San Ildefonso, folio 46, legajo 1134, PC, AGI.

217 . Miguel de Muzquiz to Marqués de la Torre, 7 July 1773, Madrid, legajo 1227, PC, AGI.

218. Martín de Asanza to Marques de la Torre, 15 August 1774, Bayamo, expediente 69, legajo 1174, PC, AGI.

219 . Marqués de la Torre to Martín de Azanza, 23 September 1774, Bayamo, PC 1179, AGI. Cuba and Spain's needs were at odds in this particular instance. Seville had a surplus of tobacco and neither an increase in the number of tobacco farms or production was desired at that time.

220. Pérez, Cuba: Between Reform and Revolution, 51-52; Aimes, Slavery in Cuba, 23-24. 
Tobacco was taken from Cuba to Spain where it was exchanged and the funds used to purchase cargoes of merchandise needed in the slave trade in Africa. From Africa the ships returned to Cuba, the holds this time filled with human chattel..$^{221}$ An unsuccessful proposal made in 1760 sought to strengthen the ties between the Real Compañia and tobacco. The company headed by José Villanueva Pico offered to. carry free of charge all the tobacco of the Real Factoria from Havana to Spain, Vera Cruz, or Tierra Firme... [as well as] all the cannon and munitions of war from Spain intended for the fortification of Habana, and to bear one half of the expenses of providing and maintaining a coastguard to prevent illicit introductions. ${ }^{222}$

In exchange, the company sought the right to introduce at least one thousand slaves per year for a period of ten years. ${ }^{223}$ But this proposal never came about and the new monopoly was authorized in 1765 . It tried one voyage to Africa, which was a complete failure, and instead contracted with British merchants to supply slaves ${ }^{224}$

The Real Factoría de Tabacos, the royal tobacco monopoly, realized the value of slave labor and provided farmers with access to funds needed to purchase slaves from the Real Compañia, the only authorized importer of slaves into the island. As early as 1764 ,

221. Aimes, Slavery in Cuba, 26-27.

222 . Ibid., 30 .

223 . Ibid.

224 . Sherry Johnson, "Where Has All the Flour Gone? El Niño, Environmental Crisis and the Emergence of Alternative Markets in the Hispanic Caribbean 1760s1770s," William and Mary Quarterly 62, no. 3 (July 2005): 365-410; Bibiano Torres Ramírez, La Compañia Gaditana de Negros (Sevilla: Escuela de los Estudios HispanoAmericanos de Sevilla, 1973). 
the Company brought a shipment of slaves into Havana, and all were distributed to the tobacco growers in the western hamlets at bargain prices. ${ }^{225}$ Five years later, the Real Factoria distributed slaves to vegueros living in the jurisdiction of Havana under the agreement that the farmers would repay the monopoly within two or three years. ${ }^{226}$ In 1773 , the monopoly again wanted to provide slaves for the vegueros, but complained to Spain that it lacked the funds necessary to purchase them. ${ }^{227}$ The monopoly's financial situation improved to such a degree by the following year that there now was an "abundance of money" available for paying the tobacco farmers for their crop as well as supplying them with slaves. ${ }^{228}$

Nor were these isolated cases. On occasion, the vegueros personally petitioned the monopoly to request slaves, most notably during the first decade of the nineteenth century. In 1801, widow and tobacco grower Doña María de la Merced Junco, a resident of the city of Matanzas, sought funds to purchase two slaves to help with the cultivation and planting of tobacco, while the following year, Güines veguero Juan José Pérez was

225 . "Nota de las cavesas de negros...," 21 March 1764, legajo 1212, SD, AGI. The slaves sold for approximately 50 pesos each, less than half the normal price.

226. Martín Xavier de Echeverria to Marqués de la Torre, 19 May 1772, Havana, legajo 1156, PC, AGI.

227 . [Unknown] to Miguel de Muzquíz, 9 October 1773, Havana, legajo 1227, PC, AGI.

228. Marqués de la Torre to Martín de Azanza, 23 September 1774, Havana, legajo 1179, PC, AGI. 
given 300 pesos for the purchase of a slave..$^{229}$ Two separate cases from 1800

demonstrate that the monopoly took the veguero's conduct into consideration when making their decisions as to who should receive the solicited funds. Citing the "good circumstances with which he has distinguished himself," the monopoly granted Manuel Díaz from Güines the money to purchase two slaves. ${ }^{230}$ Another veguero, Don José María Rodríguez from the Partido de las Virtudes, was "one of the good growers, and ...faithfully carries out his annual deliveries to the Real Factoria" the monopoly stated when they awarded him 400 pesos to purchase one slave. ${ }^{231}$ Most likely the prices paid for slaves were either subsidized or discounted, a practice that the tobacco monopoly had utilized before, since nearly fifty years earlier the average price for slaves in Havana was 220 to 300 pesos each. ${ }^{232}$

While the monopoly was willing to assist farmers in providing them with the labor force they requested, eventual repayment of the debt was expected. In the late 1760s, Havana-area veguero don Agustín Ruiz purchased two slaves on credit from the monopoly. Ruiz intended to use the extra labor to increase the amount of tobacco he planted. The terms of the agreement stated that the money would be repaid from the crop within two or three years. By May 1772, Ruiz had failed to reimburse the monopoly for

229 . Letter and testimony, 9 September 1801 , number 190, legajo 2000, SD, AGI; Letter and testimony, 25 June 1802, legajo 2000, SD, AGI.

230 . Luis de Viguri to Miguel Cayetano Soler, 28 June 1800, Havana, legajo 2000, SD, AGI.

231 . "Junta Acuerdo," 25 January 1800, legajo 2000, SD, AGI.

232. Aimes, Slavery in Cuba, 23-24, 27. 
the 480 pesos he owed. It was thought that Ruiz was hiding in the countryside and did not have a permanent residence. Local official Martín Xavier de Echevarria learned that Ruiz was in the town of Guanabacoa and was planning to escape into the mountains. Echevarria wrote to the Captain General and requested that the Adjutant Major of Guanabacoa's Volunteer Batallion put Ruiz into custody and seize his belongings in order for the government to recoup their losses. ${ }^{233}$ As late as 1792, the Real Factoria claimed that they had yet to receive payment, although the guarantor of the loan, don Andres Díaz from the Partido de San Geronimo, and Ruiz's son-in-law, don José Calixto Morales, stated they had repaid the money. ${ }^{234}$

Since workers on the vegas were simply listed by number, and not individually, it is often difficult to determine when slave labor was used, unless the slaves are listed as producing tobacco for themselves. Nonetheless, Cuban vegueros in all parts of the island used slaves in the production of tobacco, although at no time did they constitute tobacco's primary labor force. ${ }^{235}$ One indication, however, that slave labor was used to a greater

233. Echevarria to de la Torre, 19 May 1772, Havana, PC 1156, AGI.

234 . Ibid.; "Expediente de oficio contra Don Agustin Ruiz de San Geronimo cobrandole 109 pesos 6 reales que adeudo la Junta de tavacos como labrador de ellos en el Partido de Bacurana," 21 July 1792, number 9, legajo 1003, IGH, ANC. There is some discrepency about the year that Ruiz purchased the slaves. The 1772 document states that the sale took place in 1769 , while the 1792 document claims that it took place in 1765 .

235 . Slaves on the vegas of Cuba and those in the United States South shared similar demographic conditions, living and working alongside a limited number of their enslaved brethren. Before the Civil War only 0.1 percent of Southern plantations contained 200 or more slaves. Instead most Southern slaves, approximately 75 percent, lived in groups of between one and forty-nine. Peter Kolchin, American Slavery, 1619. 1877 (New York: Hill and Wang, 1993), 101. 
extent that previously believed is demonstrated from a census taken in Güines in 1774 .

Of the 319 males slaves considered to be of prime working age, 15 to 50,245 were found on the district's vegas. In contrast, just 58 male slaves age 15 to 50 were listed as residing in the area's three ingenios (sugar estates) of Nuestra Señora de la Merced, San Joseph, and Nuestra Señora de Regla. ${ }^{236}$ While overall Cuba's sugar estates individually held greater numbers of slaves than did the vegas, particularly during the mid-nineteenth century, the majority of the island's slaves did not work in sugar, even at the height of the industry in the $1860 \mathrm{~s}^{237}$

Slaves produced tobacco on their own in various parts of the island including the eastern and central districts. For Oriente's slaves, the expectation that a slave who worked on the vega should be capable of handling all aspects of tobacco production from planting, removing potentially damaging pests such as worms, cutting, hanging the tobacco in the barn, and preparing the tobacco into manageable bundles for transport to the factory meant that these slaves were particularly capable of producing quality tobacco on their own. ${ }^{238}$ In 1768 , a listing of those vegueros who had failed to turn in their

236. "Partido de Guines, Estado General que manifiest los nombres de las Haziendas Duenos aquienes corresponden numero de Casas Hombres de Blancos Pardo y Morenos Libres, y Esclavos Mugeres de todas clases havitantes en dicho Partido en que seda Conocimiento del total numero de Almas qe existen en el dia de la Fha," 22 August 1774, Güines, photocopy in AGI, AHN Cuba, Población 1766-1851, vol. 119, Levi Marrero Collection (hereafter LMC), Special Collections (hereafter SC), Dorothea and Steven Green Library (hereafter GL), Florida International University, Miami, Florida (hereafter FIU).

237 . Knight, Slave Society in Cuba, 150-51.

238 . Marrero, Azúcar, ilustración y conciencia (1763-1868) (III), vol. 11 of Cuba: economía y sociedad, Madrid: Editorial Playor, 1984, 63. 
tobacco included three groups of slaves from the Cauto district near Santiago de Cuba.

Combined these slaves, owned by local tobacco farmers Luis Miguel del Río, Felipe

Napoles, and don Melchor Delgado had produced 1,000 manojos (a tied bundle of

tobacco also known as a "carrot") of tobacco, but had not delivered them to the monopoly

as directed. ${ }^{239}$ Farther to the west, around Trinidad, in the mid-1770s slaves not only

grew tobacco, but were responsible for independently producing a considerable portion of

each year's crop. For example, in 1773,70 slave conucos were responsible for 178,000

plants, approximately 7 percent of that year's crop, whereas the following year, 170 slave

conucos accounted for an astounding $1,038,000$ plants, or nearly 18 percent of the area's

overall total. 240 Over the next two years, 1775 and 1776, Trinidad's slave conucos

contained fewer plants, just 139,500 and 39,900 respectively. Nevertheless, slaves

growing tobacco on their own in the Trinidad area were responsible for almost 1.4

239 . Matheo de Echevarria y Elguerra, "Relación de los Yndividuos Labradores que han faltado apresentar sus respectivas cosechas segun el Reconocimiento hecho de sus labranzas los que expresan en la forma siguiente," 13 September 1768, Santiago de Cuba, expediente 41, legajo 23, CG, ANC; Perdomo, Léxico tabacalero cubano, 191, 204.

240 . Fernando Muñoz, “Tazmia Gral q. manifiesta todos los tavacos q ha sembrados en esta Jurisdic demi cargo de la Ciud de Trind en el presente año con exprecion de su Partidos, numo de matatas de tavco nobres de vegueros con el total numo de demas operarios qe laboran, executado pr Dn Ferndo Muñoz, Ministro Factor de dho tavacos en esta misma Ciud pa participan a el Sr Govor Capn Gral de la Ciudad de la Hava en 3 de Abril de 1773," 3 April 1773, Trinidad, expediente 44, legajo 1186, PC, AGI; Fernando Muñoz, "Tazmia gral que manifiesta todos los Tavacos, que ay sembrados en esta Jurisdiccion de la Ciudad de Trinidad en el presente año, con expresion de todos sus Partidos, numbero de matas de tavaco, nombres de vegueros, con el total de estos y damas operarios que los cultivan, executado por Dn Fernando Muñoz, Tazmia, Mtro Factor de dhos tavacos en este misma ciudad para participican a su Sa el Sor Governor y Capn Gral de esta Ysla en 13 de Abril de 1774," 13 April 1774, Trinidad, expediente 57, legajo 1186, PC, AGI. 
million tobacco plants between 1773 and 1776, or in other words, approximately 11

percent of all tobacco plants in the district. ${ }^{241}$

In the partido of El Cano, which is located along the Jaimanitas River within the modern-day limits of Havana City Province, slaves regularly grew tobacco on their own account. In 1771, six slaves belonging to five of the district's vegueros, don Julio Capote, Julio Chico, don Manuel de Aragón, Don Felipe Torres, and a partially identified person with the surname Bello, grew tobacco for themselves. Most of these enslaved individuals worked alone, each producing between 100 and 250 cujes. Together the slaves were responsible for 750 cujes of tobacco, or about 5 percent of the district's total recorded crop for that year. ${ }^{242}$ The following year, at least seven slaves belonging to five area tobacco farmers produced more tobacco than the previous year, 1,020 cujes. Yet, only one of these slaves, the individual owned by de Aragón, may have been the same

241 . Ibid.; Ibid; Fernando Muñoz, "Tasmia General qe manifiesta el Numero de vegas qe hay en los partidos de la Ciudad de Trinidad, Numero de operarios, y Matas de Tavacos qe han sembrados en ellas en el Tasmia Gral executado por Fernando Muñoz, Ministro Factor de la dha ramo en la dha Ciudad de Trinidad para remitir a las de la Hacienda al Sor Governador y Capitan General de ellos de la Ysla de Cuba a saver," 9 June 1775, Trinidad, expediente 67, legajo 1186, PC, AGI; "Tasmia Gral que manifiesta el numero de vegas que hay en estos Partidos de la Ciudad de Trinidad Ydm de Operarios y Matas de tavaco que estan sembrados en ellas en el presente año executado por Dn Fernando Muñoz, Tazmia, Ministro Factor de dho ramo en la misma Ciudad de Trind pa remitir a la de la Hava a su Ssa el Sor Govor y Capn Gral de esta Ysla a saver," 24 May 1776, Trinidad, expediente 74, legajo 1186, PC, AGI.

242 . Vicente del Castillo, "Tazmia de los tavacos qe anproducido Los partidos del Cano Sn pedro y anafe respectiva a la cosecha del año de 1771, en qe sexprezan los Nombres de los dueños-partidarios y Nmo de los cujes," 5 May 1771, Cano, legajo 1096, PC, AGI. 
person who grew tobacco in 1771 , indicating that tobacco production may not have been an endeavor that the area's slaves engaged in year after year. ${ }^{243}$

Just to the east in nearby Xiaraco near the Rio de la Chorrera, both the number of slaves growing tobacco on their own account and the amount they produced increased in the district between 1771 and 1772. In 1772, seven slaves belonging to five different vegueros were tobacco farmers. Slightly less than half of the slaves growing tobacco belonged to the same tobacco growers who also owned vegas in El Cano, don Manuel de Aragón, Antonio de Lima, and José de Pérez. ${ }^{244}$ Each slave worked alone on his conuco and produced a limited amount of tobacco, averaging around 73 sticks. De Lima's slave working alone produced 100 cujes, while the slave owned by de Aragón grew 80, significantly less than the 250 cujes of tobacco the same slave had harvested the previous year. Conversely, the amount produced by slaves belonging to don Felipe de Torres over this period increased markedly however. Whereas his two slaves in 1771 produced just 150 cujes, by the following year, they were responsible for 600 . In all, slaves working on their own account comprised about 3 percent of the partido's tobacco labor force, and

243 . Vicente del Castillo, "Tazmia gral de los tavacos qe aproducido el partido del Cano en que se comprehende Sn Antonio Sierrestia de San Pedro y anafe, Respectiva a la cosecha del año de 1772 con notisia del No de Vegas sus duenos y operarios y porzzion de cujes," 3 May 1772, Cano, legajo 1196, PC, AGI. The other slave owners were Antonio de Lima, José Pérez, don Matias Cantos, and Felipe de Torres.

244. As noted earlier in this work, Don Manuel de Aragón and Don Felipe Torres also owned vegas in the El Cano district at this time. 
were responsible for 1,020 cujes of tobacco, less than 2 percent of the tobacco produced. ${ }^{245}$

\section{The Free Vegueros of Color}

Like their enslaved brethren, the existing historiography overlooks the presence of free people of color in the cultivation of tobacco. Near Matanzas, free black tobacco farmers in the districts of Narajal, Estancia, and San Agustín in 1770, the tazmia lists 25 out of 131 vegueros, or 19 percent, as free blacks (morenos libres). Almost half, 10, of the freed men growing tobacco had the surnames Contreras or Justiz, indicating that they likely had been owned at some point in their captivity, if not emancipated by, either the Marqués de Jústiz y de Santa Ana or the Conde de Gibacoa, local relatives who had earned their noble titles through their service to the island's tobacco industry and detailed below. The surnames chosen by two other men, Miguel Congo and Geronimo Mina, designate them as African-born slaves who had earned their freedom and wanted to pay homage to their native homeland. Free black Juan Manuel Contreras demonstrates the success that some former slaves were able to have in the area's tobacco industry, producing the second-highest amount of tobacco grown that year, 2,000 cujes, and the only moreno libre out of four people who brought in that amount. ${ }^{246}$

245 . Tbid.; "Tazmia ...Partido del Cano," del Castillo, 3 May 1772, Cano, PC 1196, AGI. The tazmia only specifies "esclavo" (slave) or "esclavos" (slaves) without giving exact figures.

246 . Rodriguez, "Tazmia de los Tavacos de los Partidos de Naranjal, Estancia y San Agustín...," 15 May 1770, Matanzas, legajo 1090, PC, AGI; Rafael Nieto y Cortadellas, Dignidades nobiliarias en Cuba (Madrid: Ediciones Cultura Hispanica, 
In some areas of Cuba between 1763 and 1817, free blacks comprised a significant proportion of those growing tobacco, particularly in the area around Trinidad, located on the central southern coast of the island. In 1772, in the entire jurisdiction controlled by local tobacco official Fernando Muñoz, just over 20 percent, or 60 out of 293, of all vegueros were free people of color. Four years later, there were more than 120 fewer vegas in the Trinidad vicinity, and while the number of white tobacco farmers had declined from 233 to 110 , there were now 68 free vegueros of color, or slightly more than 38 percent of the total veguero population of 178 . Along several rivers near Trinidad, free people of color increasingly comprised the majority or near majority of the area's tobacco farmers, such as the Agabama River where almost 39 percent of the 96 vegueros in 1773 were morenos libres (free blacks) or pardos libres (free mulattos). By 1776, the percentage of free tobacco farmers of color in this district had increased to 62 percent, or 49 out of 79.247

\section{The Military Vegueros}

Also overlooked in the existing historiography of tobacco production were retired members of the military. Despite her formidable defenses, including the Castillo del Morro, Havana fell to the British during the Seven Years' War (1756-1763), and after its

1954), 250-53, 294-95. The tradition of using the surnames of former owners is well documented. See, for example, Herbert G. Gutman, The Black Family in Slavery and Freedom, 1750-1925 (New York: Vintage Books, 1976).

247 . Fernando Muñoz, "Tazmia," 3 April 1772, Trinidad, legajo 1186, PC, AGI; Muñoz, "Tazmia...Partidos de la Ciudad de Trinidad," 24 May 1776, Trinidad, expediente 74, legajo 1186, PC, AGI. 
return to Spanish control in 1763 , emphasis was placed on reforming the island's military

and defenses. The two men entrusted with this task were Ambrosio Funes Villapando, the Conde de Ricla, named as Cuba's new governor and captain general, and Field Marshall Alejandro O'Reilly, appointed as the subinspector general of the militia and regular army. ${ }^{248}$ Threats from foreign enemies meant that military troops had long been stationed on the island, yet in the wake of the Seven Years' War, de Ricla and O'Reilly further militarized Cuba. By 1780, over 11,750 regular troops were stationed in Havana alone, making "between one in two and one in three adult white males walking Havana's streets...a peninsular soldier." 249 The increased military presence had two effects on the demographic profile of the veguero. Retiring soldiers from the regular army received their discharge and became tobacco farmers, while secondly, many Cuban residents were

248 . For more on Cuba's role in eighteenth-century conflicts, see Kuethe, $C u b a$, 1753-1815, 1-23, 29-32; Leví Marrero, Del monopolio hacia la libertad comercial (17011763) (I), vol. 6 of Cuba: economía y sociedad (Madrid: Editorial Playor, 1978), 71-111. For the British seige and occupation of Havana, see David Syrett, ed., The Seige and Capture of Havana, 1762 (London: Navy Records Society, 1970); Guillermo Calleja Leal, 1762, La Habana inglesa: La toma de La Habana por los ingleses (Madrid: Agencia Española de Cooperación Internacional, Ediciones de Cultura Hispánica, 1991); Celia María Parcero Torre, La pérdida de la Habana y las reformas borbónicas en Cuba, 1760-1773 (Madrid: Consejo de Castilla y León, 1998).

249 . Johnson, Sherry, Social Transformation, 58. Conflicts between European nations often took on a Caribbean front as corsairs and naval commanders set their eyes on the island. A series of wars between France and Spain saw Cuba attacked numerous times during the mid-1500s including the 1555 sacking of Havana by French corsair Jacques de Sores, and attacks on Baracoa in 1546, and Santiago in 1558. See Ramiro Guerra, Manual de historia de Cuba, 6th, reprint, 1921 (La Habana: Editorial Pueblo y Educación, 1980), 65-66; Kenneth R. Andrews, The Spanish Caribbean: Trade and Plunder 1530-1630 (New Haven: Yale University Press, 1978), 83-84; Pérez, Louis A., Jr., Cuba: Between Reform and Revolution, 26, 34-35; Gordon Douglas Inglis, "Historical Demography of Colonial Cuba, 1492-1780," Ph. D. Diss. (Fort Worth, TX: Texas Christian University, 1979), 60-61. 
liable for militia service as participation in the militia became mandatory for most civilian males. In Havana, for example, all men between the ages of sixteen and forty were required to join the militia, while in areas with lower populations and therefore fewer potential militia members, the age bracket was expanded to all those between fifteen and forty-five. To further extend the base from which to draw possible militia members, the height requirement was lowered to four feet eleven and one-half inches, half an inch lower than for the Spanish peninsula. ${ }^{250}$ Along with the revamped and expanded regular military, these civilians were expected to defend the island against any future attack.

Most of the island's vegueros naturally were included among the new militia ranks. ${ }^{251}$ Where the vegueros of 1717 were quick to cite their participation in the militia as a testament to their service to the crown, now many tobacco farmers protested the new requirements. ${ }^{252}$ Not only would they be watched by the government under the auspices of the tobacco monopoly, but as militia members they had to endure additional governmental scrutiny as they completed their obligatory service and training. Most tobacco farmers astutely cited other reasons when they complained about their militia

250 . Kuethe, Cuba, 1753-1815, 38-41; Johnson, Sherry, Social Transformation, 60 . Kuethe, $C u b a, 1753-1815,41$, notes that certain professions were exempt from the militia including "those engaged in medical services, notaries, tax administrators, clerics, teachers, plantation foremen, and tobacco factors" [representatives of the monopoly and head of the local warehouses].

251 . The presence in tobacco cultivation of those associated with the milita was not limited to just Cuba. Most of the vegueros in the Río de la Plata region of South America also served in the militia. Francisco de Paula Sanz, Viaje por el Virreinato del Río de la Plata: El camino del tabaco (Buenos Aires: Centro de Estudios Interdisciplinarios de Hispanoamérica Colonial, 1977), 33-34.

252 . Rivero Muñiz, Las tres sediciones, 27. 
participation however. Militia requirements interfered with their responsibilities on the vega, particularly during the tobacco harvest, they argued. ${ }^{253}$ In 1811 , the representative of Holguín's tobacco farmers, Antonio Abad Brito, protested against requiring the tobacco farmers to report for militia service and receive "instructions in the military discipline" every eight days, contending that the vegueros needed this time to work their crops. ${ }^{254}$ There may have been some validity to his argument as militia service by the vegueros particularly during times of war was cited as one of the causes for a decrease in tobacco production during the late 1790 s. 255

There were benefits to militia participation, however. One such advantage was the ability to take advantage of the fuero militar, or military privilege. Spanish King Charles III personally extended the fuero to the officers and sergeants in Cuba's militia through the use of "an obscure legal precedent."256 The fuero militar allowed the

253 . Juan Miguel de Arozena to Antonio María Bucareli, 28 June 1766, Trinidad, expediente 8, legajo 1078, PC, AGI.

254. Antonio Abad Brito to Ministro Factor, instancia, 21 April 1811, Holguín, orden 423, legajo 5, CG, ANC.

255 . Juan de Mercolaetas and Pedro Antonio de Gamon to Captain General, 26 August 1799, legajo 2018, SD, AGI.

256. Allan J. Kuethe, "The Development of the Cuban Military as a Sociopolitical Elite, 1763-83," Hispanic American Historical Review 61, no. 4 (1981): 700. For more on the fuero militar throughout Latin America, see Lyle N. McAlister, The "Fuero Militar" in New Spain, 1764-1800 (Gainesville: University of Florida Press, 1957); Christon I. Archer, The Army in Bourbon Mexico, 1760-1810 (Albuquerque: University of New Mexico Press, 1977); Leon Campbell, "The Military Reform in the Viceroyalty of Peru, 1762-1800," Ph. D. Diss. (Gainesville: University of Florda, 1970); Joseph P. Sanchez, "African Freedmen and the Fuero Militar: A Historical Overview of Pardo and Moreno Militiamen in the Late Spanish Empire," Colonial Latin American Historical Review, Spring 1994, 165-205. 
vegueros to present their legal cases before a special military tribunal, a right previously granted to only His Majesty's Royal Guard, and "in a hierarchical colonial society...[it] conveyed special distinction and prestige and reinforced a sense of corporate honor and espirt de corps." 257 Not only did the vegueros get to take advantage of these benefits, but their immediate families did as well. ${ }^{258}$ Full enjoyment of the fuero was of little use to the vegueros when there was no military court to hear their case, as the Cuba's captain general acknowledged in $1772 . .^{259}$ However, they could appeal through their local captains and have their case taken up through the ranks, as many did.

Many of the tobacco farmers in Mayarí, located near eastern Cuba's north coast, were also members of the local militia. As early as January 1755 , Santiago de Cuba's governor, Lorenzo de Madriaga, noted that numerous Mayarí's residents, including a lieutenant in the Compañía de Mayarí, don Felix José Rodríguez, worked in tobacco. ${ }^{260}$ Just over ten years later, a monopoly official noted that 81 members of the Mayarí district's militia owned tobacco farms, including 11 captains of the white and free colored militias. The vegueros were fairly evenly split between the white (45) and the colored (43) companies. The majority, 33 , of those assigned to the free black militia were

257 . Kuethe, "Cuban Military as a Sociopolitical Elite," 700; Kuethe, Cuba, $1753-1815,44-45$.

258. Johnson, Sherry, Social Transformation, 64-65.

259 . Marqués de la Torre to Gaspar Gelabert, 30 June 1772, Havana, expediente 24, legajo 1186, PC, AGI.

260 . Lorenzo de Madriaga to Juan Miguel Portuando, orden, 2 January 1755, Santiago de Cuba, orden 270, legajo 7, CG, ANC. 
members of the mulatto (pardo) group, while 10 were part of the moreno (black)

group. ${ }^{261}$ By 1770 , only a third of all the militiamen and officers who had owned vegas in 1768 remained on the area's tazmia of 109 vegas. These militia members and vegueros owned 26 tobacco farms containing a total of $1,016,000$ plants tended by 96 people, possibly including the militiamen themselves. Most owners, 73 percent, had three or more people working in the tobacco fields, and 63 percent of these had between five and seven operarios. Five of the 12 vegas employing five or more workers, were owned by men associated with the pardo militia groups. Four of these men, Luis Miranda, Miguel Felipe Romero, Tomás Barrientos, and Juan Ventua de Pozo, each owned vegas with 60,000 tobacco plants, the first three tended by five people and the last by six. ${ }^{262}$ Miranda and de Pozo surely knew one another, since in 1768 they had served together in the same militia company under the command of Captain Vicente Barrientos. ${ }^{263}$ The remaining two-thirds of those who had owned vegas in 1768 and were members of the militia may have grown older and were no longer required to register for duty, left the area, no longer grew tobacco, or perhaps were deceased.

261. Luis de Echevarria, "Lista de los milicianos duenos de vegas de este partido Mayari que yo Don Luis de Echevarria Factor de los tavacos del formo en cumplimento..." 9 July 1765, Santiago de Cuba, orden 10, legajo 26, CG, ANC.

262. Luis de Echeverria, "Tazmia de los Partidos correspondientes a la Factoria de Mayarí respectiva a la cosecha de 1770," 12 April 1770, Mayarí, legajo 1080, PC, AGI.

263 . Luis de Echevarria, "Lista de los milicianos dueños de vegas," 9 July 1765 , Santiago de Cuba, orden 10, legajo 26, CG, ANC. 
Another veguero with military ties was Captain Bernabé Hernández, who was involved in Cuba's tobacco industry over several decades. During the 1770 s, Hernández regularly appears in the tazmias for the Xiaraco district, and was cited as owning one vega worked by at least 8 and as many as 10 people. Cultivating between 2,000 and over 3,500 cujes (sticks) of tobacco, Hernández usually was among the largest single-farm tobacco producers in the partido. In 1770, eight people worked on the vega and tended 2,200 sticks of tobacco, making Hernández the highest producer in the Xiaraco district for that year. Just two years later, he had expanded his labor force to ten and as a result, the amount of tobacco he cultivated increased to 3,600 cujes, making his vega responsible for the most tobacco grown on any one farm in the area. Only Francisco Hernández and Nicolás Guzman, who owned two vegas each, brought more tobacco to the royal monopoly that year. The tobacco industry in Xiaraco had expanded quickly during the first few years of the decade, rising from just 86 vegas, 283 workers, and 51,290 cujes in 1770 to a high of 143 farms, 361 operarios (workers) and 118,206 sticks in 1773 . Even as the area's tobacco industry began a period of decline, dropping to 110 vegas by 1774 , Hernández's commitment to the tobacco industry remained strong. Although his labor force temporarily decreased from nine to eight workers between 1773 and 1774 , there was no negative impact on his vega's production which saw an increase from 2,000 sticks in 1773 to 3,000 the following year. By 1775,44 vegas were no longer in operation in the district and active farms had dropped to 66 and continued to decline until 1776 when just 49 farms remained, responsible for producing just 38,750 cujes, a decline of nearly 80,000 cujes in the span of three short years. Yet, even during this decline, Captain 
Bernabé Hernández restored his labor force to ten, a figure he maintained the following year as well. ${ }^{264}$ By the early 1790 s, the retired militia captain had left Xiaraco and was now living in Santa María del Rosario, the "private fiefdom" created in the 1730s by the Conde de Casa Bayona and located to the southeast of Havana, where he served as the local tobacco farmers' representative (diputado). ${ }^{265}$

Captain Nicolás del Pino, born in the Canary Islands, spent many years growing tobacco in the Güines district. A census (padron) from 1767 showed ten people in his household, including his wife and three children. Tazmias from Güines show that the 38year-old del Pino grew tobacco as early as 1768 . By 1771 , he owned two vegas which were worked by six people, perhaps including his slaves, and produced 3,500 cujes of tobacco, more than all other tobacco farmers in the district with the exception of two individuals. Just three years later, in 1774, the tazmia listed del Pino with just one farm and a reduced his labor force of five people, yet two years later, the now 46-year-old

264 . Bernabe Hernández, "Tazmia de los tabacos de el Partido de Xiaraco respectiba a la cosecha de este presente año de 1770," 9 May 1770, Xiaraco, legajo 1094, PC, AGI; Bernabé Hernández, "Tazmia de los Tavacos respectiba a la cosecha del año de 1772, Parto de Xiaraco," 1 June 1772, Xiaraco, legajo 1195, PC, AGI; Bernabé Hernández, "Tazmia de los Tavacos respectiba a la cosecha de este año de 1773, Partido de Xiaraco," 17 June 1773, Xiaraco, legajo 1195, PC, AGI; Bernabé Hernández, "Partido de Xiaraco, Tazmia de los Tabacos qe se han cojido en dho Partido, respectiva a la cosecha de este presente año de 1774," 16 June 1774, Xiaraco, legajo 1195, PC, AGI; Bernabé Hernández, "Partido de Xiaraco, Tazmia de los cujes de Tabaco qe han cojido en dho Partido respectiva a la cosecha de este presente año de 1775," 6 July 1775, Xiaraco, legajo 1195, PC, AGI; Bernabé Hernández, "Partido de Xiaraco, Tazmia de los cuges de Tabaco qe se han cogido en dicho Partido respectiba a la cosecha de este presente año de 1776," 7 July 1776, legajo 1193, PC, AGI.

265 . Conde de Casa Bayona to Luis de las Casas, 6 October 1791, Havana, legajo 1461, PC, AGI; Johnson, Sherry, Social Transformation, 50. 
isleño was again listed with two tobacco farms, indicating that perhaps he had sold one farm between 1771 and 1774 and purchased another in the two-year-span between 1774 and $1776 .{ }^{266}$ Another possibility is that del Pino had temporarily stopped growing tobacco on one farm while continuing to do so on the other. This practice of allowing the land to lay fallow in the hopes of restoring its fertility was not an uncommon one for Virginia's or Mexico's tobacco farmers, since tobacco took such an enormous toll on the soil, but was not usually followed in Cuba as discussed in greater detail in Chapter 2.267

\section{The Clerical Vegueros}

Throughout Latin America, the Catholic Church and its clergy were involved in numerous economic ventures particularly agriculture. As producers of grain, grapes, and sugar in Peru or ranchers in Argentina, the Catholic Church in the New World expanded its wealth and power through diverse agricultural enterprises. 268 Although Cuba's

266. Francisco Gama, "Padron de la gente que hay en este Partido de los Guines sin yncluir las hasiendas las vegas y casas del lugar...," 6 June 1767, Güines, legajo 1096, PC, AGI; "Noticio de los Vecinos que comprehende el Partido de los Guines y como Capn doy al Sr Gobor y Capn Genl con arreglo a su orden de 20 de Marzo de 1786," photocopy in AGI, AHN, Cuba, Población, 1766-1851, volume 119, LMC, SC, GL, FIU; Gama, "Tasmia General...Partido de los Güines...," 14 April 1768, Güines, legajo 1090, PC, AGI; Gama, "Tasmia...Partido de Güines...," 15 May 1771, Güines, legajo 1090, PC, AGI; Gama, "Tazmia...Partido de los Güines...," 8 June 1774, Güines, legajo 1195, PC, AGI; Gama, "Tasmia...Partido de Güines...," 16 June 1776, Güines, legajo 1195, PC, AGI.

267 . Meining, Atlantic America 1492-1800, 154; Silver, A New Face on the Countryside, 163; Brennan, Tobacco Leaves, 43; Deans-Smith, Bureaucrats, Planters, and Workers, 116.

268 . Nicholas Cushner, Lords of the Land: Sugar, Wine, and Jesuit Estates of Coastal Peru, 1600-1767 (Albany: State University of New York Press, 1980); Nicholas 
Catholic Church never "possessed grand riches," the island's religious orders and individual clergy members were involved in numerous agricultural endeavors including the tobacco industry. ${ }^{269}$ One such example was Father Dionisio Manrique, born in Móstales, Spain to Andrés Manrique and María Delgado y Vargas. While serving as the local parish priest in San Felipe y Santiago, near Batabanó, he owned a tobacco farm in 1774. That year, Father Manrique's vega produced 3,500 cujes of tobacco, making him the third-largest producer of tobacco in the area behind don Pedro Menocal and Antonio Gutierrez both with 4,000 cujes. Under normal circumstances in colonial Cuba, 3,500 cujes was a large amount, but Batabanó must have been experiencing a particular good year as 23 vegueros out of 53 in the entire district all produced at least 1,000 cujes of tobacco. Although three other farmers each employed more workers, with four people tending Father Manrique's tobacco fields, the priest had more people working for him on his vega than 80 percent of the other vegueros listed as having operarios. Ten years later, on December 20, 1784, Manrique died in Havana, and was buried in Havana's cathedral,

P. Cushner, Farm and Factory: The Jesuits and the Development of Agrarian Capitalism in Colonial Quito, 1600-1767 (Albany: State University of New York Press, 1982); Nicholas P. Cushner, Jesuit Ranches and The Agricultuaral Development of Colonial Argentina, 1650-1767 (Albany: State University of New York Press, 1983); Kendall W. Brown, "Jesuit Wealth and Economic Activity with the Peruvian Economy: The Case of Colonial Southern Peru," The Americas 44, no. 1 (July 1987): 23-43.

269 . Leví Marrero, Azucar, ilustración y conciencia (1763-1868)(V), vol. 13 of Cuba: economía y sociedad (Madrid: Editorial Playor, 1986), 9; Mercedes García Rodríguez, "Presencia Jesuita en la Economía de Cuba: Siglo XVIII," Ph. D. Diss. (Havana, Cuba: Universidad de la Habana, 1999). 
and, as requested in his will, one year later his body was disinterred and reburied in the church in which he had served as a priest. 270

Father Manrique was not the only man of the cloth who owned a vega. In the area around Bayamo in 1773, four separate priests were responsible for farms containing a total of 115,500 tobacco plants. The vega belonging to don Andres Josef Tamayo, Presibtero (priest), in the partido of Bayamo had 11,000 plants, while the farm owned by Father Santiago Escalante in contained 10,500 plants. Based on calculations as to the number of tobacco plants that could be grown in a given area, these farms were approximately two acres in size. The vegas located in the district of Casibaroa owned by Father don Fernando Gonzales and Father Felipe Ramirez were significantly larger at about 10 acres each and grew 50,000 and 44,000 tobacco plants, respectively, making Father Gonzalez tied for the second-largest tobacco producer in the district, and Father Ramírez the third-highest. Together, the vegas operated by these last two priests contained nearly 8 percent of the Casibaroa partido's entire crop of $1,267,000$ plants. ${ }^{271}$

270 . Manuel Pérez-Beato, Toponimia, vol. 1 of Habana angigua, (Habana: Seone, Fernández y Ca., 1936), 202-203; Simon de la Cruz, "Tazmia de los Tavacos del Partido de Govea, y sus anexos respectiva a la cosecha de este presente año de 1774," 21 June 1774, Govea, PC 1196, AGI. Pérez-Beato also notes that the extramuros (outside the city walls) Calle de Manrique, which began at the Malecón and ended at the Calle de las Figuras, and known as the Calle de Terranova in 1827, was named for Father Manrique.

271. Antonio Laso de la Vega, "Tasmia de los tavacos de los Partidos correspondientes a la Factoria de la Villa del Bayamo respectiva a la cosecha de 1773," 28 February 1773, Bayamo, legajo 1174, AGI. Several estimates indicated that an average of 5,000 plants could be grown on an acre. See Deans-Smith, "The Money Plant," 386. 


\section{The Noble Vegueros}

While the impact of slaves, free blacks, former members of the military and others has been downplayed in the existing historiography of Cuba's tobacco farmers, the presence of the island's noble elites has been completely omitted. ${ }^{272}$ Research conducted for this study shows that numerous members of Cuba's noble elites participated fully in the island's tobacco industry and were involved in virtually every aspect of tobacco from owning tobacco farms or the mills used to grind tobacco to donating land to the crown to be used for new vegas. For one man, Spanish-born Captain Juan Núñez de Castilla, tobacco was responsible for his rise from immigrant tobacco farmer to a titled member of Cuba's colonial society. Born in Almuñecar, Granada in 1660, Núñez de Castilla founded the city of San Felipe y Santiago on his hacienda Bejucal with the hopes of encouraging the migration of tobacco farmers to the area, and in recognition of his efforts, he was given the title of Marqués de San Felipe y Santiago in 1713. Nearly one hundred years later, his great-grandson, Juan Clemente Núñez del Castillo y Molina, the fourth holder of the title of Marqués de San Felipe y Santiago and the first Conde del Castillo, similarly offered land to be used for tobacco cultivation. Indeed, between 1700 and 1764 , six men either owed their noble titles to their participation in or had ties to the island's tobacco industry. ${ }^{273}$ While vega owners holding titles of Castile were not as common as

272. Moreno Fraginals, The Sugarmill, 21. Moreno Fraginals notes that Arango viewed tobacco planters as "miserable pejugaleros (outservants), and he prided himself on the fact that his rich compatriots neither owed their fortunes to tobacco, nor crossed the threshold of the Factoría."

273. Marrero, Azúcar, ilustración y conciencia (1763-1868)(III), vol. 11 of Cuba: economía y sociedad, 22-23. The junior Núñez del Castillo's offer of land to be 
free black tobacco farmers or those with military connections, the participation by the noble elite in tobacco growing adds additional weight to the thesis that those supporting Cuba's colonial tobacco industry were an extremely diverse group that included all levels of Cuba's society.

One noble who did own a vega was the Marquesa de Montehermoso. The wife of Nicolás de Cárdenas Vélez de Guevara, recipient of a royal title in 1764 in acknowledgment of his defense of Havana during the English occupation, owned a tobacco farm in 1774 in the district of San Antonio located southwest of Havana. Worked by just two laborers, the farm produced 600 cujes of tobacco, a moderate amount considering that the highest amount grown in the partido was 3,000 cujes and the smallest a mere 100 cujes. $^{274}$ Ironically, while one historian claims that the Marqués de Cárdenas de Montehermoso referred to tobacco planting as a "pursuit of the lower orders," the Marquesa was not above supplementing her income from such endeavors. ${ }^{275}$

used for tobacco is discussed in greater detail below. The men with noble titles and ties to tobacco were the Marqués de Casa Torres, Laureano de Torres Ayala; the aforementioned Marqués de San Felipe y Santiago; the Conde de Casa Bayona, Captain José Bayona y Chacón; Marqués de Jústiz y Santa Ana, Juan José de Jústiz y Umpirre; and Domingo de Lizundia y Odria, the Marqués del Real Agrado. See Levi Marrero, Azúcar, ilustración y conciencia (1763-1868) (V), vol. 13 of Cuba: economía y sociedad (Madrid: Editorial Playor, 1986), 39-40.

274. "Tazmia de los tavacos de los Partidos que se comprehenden en la diputacion de Capn Dn Vicente del Castillo respectiva a la cosecha de 1774," 10 July 1774, Partido del Cano, legajo 1192, PC, AGI; Marrero, Azúcar, ilustración y concencia (1763-1868)(V), vol. 13 of Cuba: economía y sociedad, 39.

275. Moreno Fraginals, The Sugarmill, 21-22. 
Another Cuban noble involved in tobacco planting was Francisco José Chacón y Torres, the second Conde de Casa Bayona. Born in Havana on April 2, 1712 to cousins Captain José Bayona y Chacón and doña Luisa Chacón y Castellón, he was also the nephew of the founder of Santa María del Rosario located south-east of Havana. His father served three times as Havana's mayor, and in 1733 received the title of Conde de Casa-Bayona Quiebrada-Hacha, making him among the first five men in Cuba to receive such a distinction. In 1746, the younger Chacón followed in the footsteps of his father and served as mayor of Havana. The marriage between Chacón and his niece, Mariana Josefa Tomasa de Herrera y Chacón, the daughter of the fourth Marqués de Villalta who was also one of the first five noble families, further cemented his prominent family connections within Cuba's creole elites. While Chacón's service during the war with Britain was not distinguished, his contribution of 30,000 pesos for repairs and compensation to the dependents of those who died in combat further advanced his social standing. Alejandro O'Reilly chose him during the reorganization of Cuba's military to serve as lieutenant colonel of Havana's white volunteer infantry militia, a unit which included many distinguished members of creole society including a knight of the Order of Santiago. 276

The Conde de Casa-Bayona's vast agricultural holdings included sugar and cattle, and by June of 1775 , they included tobacco as well. The tazmia submitted by the captain

276 . Nieto y Cortadellas, Dignidades nobiliarias, 114-15; Leví Marrero, Del monopolio hacia la libertad comercial (1701-1763), vol. 8 of Cuba: economía y sociedad (Madrid: Editorial Playor, 1980), 167; Marrero, Cuba: economía y sociedad, 53; Kuethe, Cuba, 1753-1815, 52, 57. 
of the Xiaraco district, Bernabé Hernández, noted that the Conde de Casa Bayona owned a single vega, located in the partido of Xiaraco. The farm's three laborers produced 900 cujes of tobacco, and while the vega was not the largest tobacco producer, it contributed slightly more than 5 percent of the total crop for the district that year. ${ }^{277}$ Tazmias from the three previous years do not list Chacón as owner of a vega, indicating that the farm was most likely purchased in late 1774 or early 1775 . The following year the Conde de Casa Bayona no longer owned a vega in the Xiracao district, supporting the evidence presented elsewhere in this chapter that indicates a high turnover in ownership of tobacco land. ${ }^{278} \mathrm{~A}$ total of 216 individuals between 1772 and 1776 owned vegas in Xiaraco, far more than the maximum number of farms, 143, present in any one year. Even more revealing, only 15 vegueros out of 216 consistently produced tobacco every year during this period. ${ }^{279}$ The quick entry and exit of the Conde de Casa Bayona into the partido's tobacco-growing industry was reflective of the overall patterns found throughout colonial Cuba, but also may have been influenced by other factors more specific to Xiaraco.

277 . Kuethe, Cuba, 1753-1815, 57; Bernabé Hernández, "Tazmia de los cuges de Tabaco qe se han cojido en dho Partido, respectiva a la cosecha de este presente año de 1775," 6 July 1775, Xiaraco, legajo 1195, PC, AGI.

278 . Hernández, "Tasmia...cosecha del año de 1772, Parto de Xiaraco," 1 June 1772, Xiaraco, legajo 1195, PC, AGI; Hernández, "Tasmia...la Cosecha de este año de 1773, Partido de Xiaraco," 17 June 1773, Xiaraco, legajo 1195, PC, AGI; Hernández, "Partido de Xiaraco, Tazmia...cosecha de...1774," 16 June 1774, legajo 1195, PC, AGI; Bernabé Hernández, "Partido de Xiaraco, Tazmia...cosecha...1776," 7 July 1776, Xiaraco, legajo 1193, PC, AGI.

279 . Tbid. 
Tobacco in the Xiaraco district reached its apex in the early 1770s. There were a total of 99 tobacco farms in 1772, and the following year the number of vegas increased to 143 , the largest number of vegas in the partido at any time between 1772 and 1776 . By 1774 , however, the area's tobacco industry entered a period of decline. From 110 tobacco farms that year, it slipped to 66 in 1775 , and by 1776 there were just 49 vegas remaining in the entire district. Tobacco no longer was an important source of income for many people in the area. While 140 individuals owned a vega in 1773 , the highest during this period, by 1776 only 46 people held tobacco farms. The impact on those laboring in the fields was even more dramatic, a decline of more than a third to just 101 workers overall in $1776 .{ }^{280}$ Tobacco production in the partido naturally followed a similar downward trend. At its peak in 1772, the district produced 60,850 arrobas of tobacco. Over the next two years, production began to decline, dropping to just over 59,000 arrobas in 1773 , and around 42,000 arrobas in 1774 . About the same time that the Conde de Casa Bayona most likely purchased his vega, tobacco in the district was on what would become an irreversible down slide. Between 1775 when production was a mere 17,642 arrobas and 1803, the partido of Xiaraco never again saw its tobacco production exceed 28,000 arrobas. This severe drop was not a result of lower prices paid by the monopoly however, as the prices paid for the highest grade of tobacco in Xiaraco

280 . Ibid. 
actually increased from 35 reales per arroba between 1763 and 1785, to 60 reales per

arroba by 1803 , and instead was the product of a devastating hurricane season. ${ }^{281}$

The presence of these two important Cuban nobles as owners of tobacco farms, along with the other groups discussed previously, clearly dispels the thesis that those supporting the island's tobacco cultivation were a homogeneous group. Other Cubans holding titles of Castile were even more involved in Cuba's tobacco industry. As early as 1775, Spain’s minister of finance, Miguel de Múzquiz, recognized two particular Cuban nobles, the Conde de Gibacoa and the Marqués de Justiz, as the "principal tobacco growers" in the jurisdiction of Matanzas. ${ }^{282}$ The cousins owned a tobacco mill, or molina, in Matanzas, and as early as the late 1760 s were contracted to produce ground tobacco in the district. Their original contract was extended for five additional years in 1769 , but by the following year was reduced to just three. ${ }^{283}$ Like other wealthy Cubans,

281. Manuel Ramires de Arellano, "Estado que manifiesta los Tabacos que han entragado los Labradores de este fruto en la Factor general de la Havana, y Subalternas de la Ysla desde el año de 61 en que se establecío el Ramo por cuenta de la Real Hacienda hasta fin de 1803," 4 August 1804, Real Factora de Tavacos, Havana, numero 9, signatura 9454, legajo 209, Real Consulado y Junta de Fomento (hereafter RC), ANC; Manuel Ramirez de Arellano, "Estado que manifiesta los distintos precios á que se ha pagado cada arroba de Tabaco á los Labradores de este fruto, desde el establecíminento del Ramo por cuenta de la R1 Hacienda el año de 1761 hasta el presente de 1804," 4 August 1804, Real Factoria de Tabacos de la Havana, numero 10, signatura 9454, legajo 209, RC, ANC; Johnson, Sherry, "Where Has All the Flour Gone?".

282 . Miguel de Múzquiz to Marqúes de la Torre, 25 December 1775, Madrid, document 52, folio 884-886, legajo 1227, PC, AGI.

283 . Julian de Arriaga to Antonio María Bucareli, 18 July 1769, Madrid, legajo 1134, PC, AGI; Julian de Arriaga to Antonio María Bucareli, 22 October 1769, San Lorenzo, folio 54-56, legajo 1134, PC, AGI; Julian de Arriaga to Antonio María Bucareli, 22 June 1770, Aranjuez, folio 100, legajo 1134, PC, AGI. 
these nobles were involved in other economic pursuits including cutting wood, which they were accused of doing without the proper licenses. ${ }^{284}$ Around the turn of the century, other nobles, specifically the Marqués de San Felipe y Santiago, the Conde de Mopox, and the Conde del Castillo became involved in Cuba's tobacco industry by promoting the cultivation of the plant. Each gave land, by donation or sale, to the crown for the sole purpose of growing tobacco. The Marqués de San Felipe y Santiago, and the Conde del Castíllo each donated 100 caballerias of land. Following distribution of the land donated by the Conde del Castíllo, at least 34 individuals received tobacco land, varying in size from a single caballería to, in one instance, 21 caballerías. ${ }^{285}$ Not all of the land donated for growing tobacco was considered suitable for that purpose, however. Although the land given by the marqués was described as "very analogous to the cultivation of tobacco," two witnesses provided written testimony that out of the 294 caballerias donated by the Conde de Mopox, only 94 along the river were appropriate for tobacco. Some claimed that this should invalidate the sale, nevertheless, the contract

284. Juan Baptista Bonet to Marqués de la Torre, 4 February 1775, legajo 1178, PC, AGI.

285. Rafael Gomez Rouboud to Miguel Cayetano Soler, 17 February 1806, Havana, legajo 2000, SD, AGI; "Repartimiento de las cien cavallerías de tierra donadas a S.M. en el Corral desmolído la Magdalena por el Exmo Señor Conde del Castíllo para vegas de tabaco, concluído en 30 de octubre de 1806," legajo 670, Mapas y Planos (hereafter MP), SD, AGI. 
stood and it was argued that the land was indeed good, although the Junta decided against purchasing additional land. ${ }^{286}$

The Conde de Mopox's problems with the royal tobacco monopoly continued. Born Joaquín Beltrán de Santa Cruz y Cárdenas, he was well placed in Cuban society as heir to the Condado de San Juan y Jaruco which he inherited in 1804, and related by marriage to the first Conde de Casa Montalvo. While in Spain during the 1790s, he befriended Manuel Godoy and was granted the title of Conde de Santa Cruz y Mopox. Contracted to provide tobacco to the monopoly, he delivered the 1804 crop which left him with a positive balance of 14,618 pesos, as well as that of 1805 which increased his balance to 33,412 pesos. Despite a large debt that he owed the Spanish treasury, government officials were not concerned. "The Conde de Mopox y Jarcuco has just given me a positive test of his love and loyalty to the King, and of his predilection to be interested in the tobacco monopoly."287 By late March of 1807, the head of the tobacco monopoly in Havana, Rafael Gomez Roubaud, informed Godoy that their mutual friend was gravely ill. On April 5, the count died in Havana at the age of 37 years 6 months,

286. Rafael Gomez Rouboud to Miguel Cayetano Soler, 17 February 1806, Havana, legajo 2000, SD, AGI; Junta, 3 January 1800, legajo 2018, SD, AGI; Junta, 3 January 1800, legajo 2018, SD, AGI.

287. Rafael Gómez Roubaud to Miguel Cayetano Soler, 31 July 1806, Havana, legajo 198, Ultramar, AGI; Rafael Gómez Roubaud to Miguel Cayetano Soler, 17 April 1805, Havana, legajo 253, Ultramar, AGI. 
leaving an outstanding debt to Spain's treasury of over a million pesos, but "this debt was forgiven his heirs!'288

\section{The Female Vegueros}

Nearly all of the vegueros discussed up to this point regardless of their race, occupation, or social standing have been males. Yet, the presence of women as promoters of tobacco cultivation predates this study as demonstrated by the name of Ynes de Arvelo from the Canoa district among a list of individuals who had turned in leaf tobacco housed in the Real Fuerza. ${ }^{289}$ Like their male counterparts, the females involved in the tobacco industry were from various racial and social backgrounds. Social codes strictly controlled the lives of some of Cuba's women. These codes dictated the lives of those considered to be of respectable social standing and prohibited them from walking two blocks on Havana's streets and kept them in near seclusion. For these women, activities such as visiting other ladies, reading, peering out from behind the iron bars of their homes, going on carriage rides, or attending church were acceptable ways to spend their time. The same rules of conduct did not apply to women of lower socioeconomic

288. Rafael Gómez Roubaud to Miguel Cayetano Soler, 31 July 1806, Havana, legajo 198, Ultramar, AGI; Rafael Gómez Roubaud to Principe de la Paz, 29 March 1807, Havana, legajo 198, Ultramar, AGI; Rafael Gómez Roubaud to Miguel Cayetano Soler, 12 April 1807, Havana, legajo 198, Ultramar, AGI; Principe de la Paz to Miguel Cayetano Soler, Madrid, 20 June 1807, legajo 198, Ultramar, AGI; Kuethe, Cuba, 1753$1815,152-54$.

289 . Juan Tio, "Noticia del tavaco en Rama de varios Partidos que sea reconizido, segun e manifestado en esta RI Fuerza a saver," 13 May 1760, Havana, legajo 2016, SD, AGL 
standing, including free blacks or slaves, however. ${ }^{290}$ Despite these societal constraints,

new research has begun to establish the personal agency exercised by Cuban women in financial transactions. ${ }^{291}$ Female vegueros include doña Bernabela Piloto whose four workers cultivated 500 cujes of tobacco near Guanabacoa in 1770 or Gertrudis Oliva who rented a vega in the partido of Govea and had three workers who produced 1,000 cujes of tobacco in 1774. Widows were also found among the diverse ranks of the island's vegueros including Matanzas-area residents María Antonia and María Lopez in 1770, or doña María Perez the following year. ${ }^{292}$

290 . See Steve J. Stern, The Secret History of Gender: Women, Men, and Power in Late Colonial Mexico (Chapel Hill: University of North Carolina Press, 1995); Susan Midgen Socolow, The Women of Colonial Latin America (Cambridge: Cambridge University Press, 2000); Ann Twinam, Public Lives, Private Secrets: Gender, Honor, Sexuality, and Illegitimacy in Colonial Spanish America (Stanford, California: Stanford University Press, 1999); Sueanne Caulfield, "The History of Gender in the Historiography of Latin America," Hispanic American Historical Review 81 (August-November 2001): 477-81; Lavrin and Courturier, "Dowries and Wills."; Martínez-Alier, Marriage, Class and Colour in Nineteenth-Century Cuba; Luis Martínez-Fernández, Fighting Slavery in the Caribbean: The Life and Times of a British Family in Nineteenth-Century Havana (Armonk, NY: M.E. Sharpe, 1998), 65-77; Luis Martínez-Fernández, "The 'Male City' of Havana: The Coexisting Logics of Colonialism, Slavery, and Patriarchy in NineteenthCentury Cuba," in Women and the Colonial Gaze, edited by Tamara L. Hunt and Micheline R. Lessard (New York: New York University Press, 2002), 104-16.

291 . Sherry Johnson, “'Señoras en Sus Clases no Ordinarias': Enemy Collaborators or Courageous Defenders of the Family?" Cuban Studies/Estudios Cubanos 34 (2004): 25-30.

292. Hernández Pulgarón, "Estado...Partidos de Bacuranado, San Jeronimo y Baxunallado...," 6 April 1770, Guanabacoa, legajo 1090, PC, AGI; Simon de la Cruz, "Tazmia de los Tavacos...Partido de Govea...," 21 June 1774, Govea, legajo 1196, PC, AGI; Ramón José Rodríguez, "Tazmia...Partidos de Naranjal, Estancia y San Agustín....," 26 May 1770, Matanzas, legajo 1090, PC, AGI; Ramón José Rodríguez, "Tasmia de los Tavacos del Partido de Yumurí, relativa a la cosecha del presente año de 1771," 12 May 1771, Matanzas, legajo 1090, PC, AGI. 
At least since the nineteenth century, chroniclers and scholars of Cuban history have argued that tobacco was a pursuit of the lower classes. Faithfully tending to row after row of tobacco plants, the image of the poor, white tobacco farmer became ingrained in the fabric of not only Cuban history but of the island's cultural and political life as well. Again placing tobacco and sugar in contrast, Fernando Ortiz wrote,

The personal element always predominated in tobaccogrowing, and there was a patriarchal, intimate quality about its work. Sugar was an anonymous industry, the mass labor of slaves or gangs of hired workmen, under the supervision of capital's overseers. Tobacco has created a middle class, a free bourgeoisie; sugar has created two extremes, slave and masters, the proletariat and the rich. ${ }^{293}$

To Ortiz and others, the veguero represented the quintessential small farmer, living on a small plot of land that he may not have even owned, and employing methods of agriculture probably not that different than those used generations earlier. The veguero therefore characterized an earlier, more rustic era, while those who grew sugar symbolized the plantation system and a proto-industrial step toward capitalism itself.294

Tazmias provide one of the best windows into the composition of those owning or renting land on which tobacco was grown. It is these period documents, along with other sources, which clearly indicate that the existing historiographical image of the veguero as a poor, white, Canary Islander is inaccurate at best. Clearly, Cuba's veguero population was far more diverse and complex than the literature currently suggests. As this study has indicated, people of color, both slave and free, worked alongside their white counterparts

293. Ortiz, Cuban Counterpoint, 65.

294 . Tbid., 71, 252, 289. 
in the island's tobacco industry from 1763 to 1817 . The prevailing historiographical view of Cuba's colonial tobacco farmers, particularly those in western Cuba, as consisting exclusively of white, Canary Islanders deserves substantial revision and will be addressed in detail in Chapter 4. The various groups from which Cuba's vegueros were drawn, as discussed in detail above, was not an anomaly limited only to the island. Vegueros in other Latin American locations such as Mexico also covered a vast spectrum of that colony's society in which poor farmers and Indians, as well as the wealthy, all grew tobacco. Indeed, one of the most prominent planters in orangeade, Mexico offered to expand his production allotment to between 12 and 13 million tobacco plants, an amount of tobacco that would cover approximately 2,400 acres. His current allotment was 6.5 million plants, significantly higher than most other vegueros in the area who tended between 50,000 and 300,000 plants. ${ }^{295}$ The presence of members of the nobility was also found in Mexico where the largest tobacco landholders in Orizaba and Córdoba were the Conde del Valle de Orizaba, the Marqués de Valle de la Colina, and the Marqués de Sierra Nevada, all absentee owners who rented out their properties. ${ }^{296}$

With the exception of noting slaves that labored in tobacco for their own benefit, tazmias almost never indicated the names, status, or other identifying information about each individual worker on the vega and instead listed their numbers under the general label of operarios. While one might reasonably assume that a vega listed as having one "worker including the owner" meant that the owner alone tended to the tobacco it is

295 . Deans-Smith, Bureaucrats, Planters, and Workers, 11, 87, 386.

296 . Ibid., 111. 
difficult for us to know whether this was accurate as an owner might have employed a hired hand or slave to labor in the fields. Yet, whether or not the person listed as owner or veguero, be they poor or among the highest members of Cuban society, personally worked in the fields is ultimately of little importance. The mere fact that diverse groups of people including those with sufficient social standing to be called "don," free blacks, slaves, members of the military, clergy, and even those with noble titles or women grew tobacco or had it grown on their behalf is significant and completely alters the existing view of rural Cuban society during the late eighteenth and early nineteenth centuries. 


\section{Chapter 4:}

\section{A View Down Tobacco Road: A Case Study of Pinar del Río}

West of Havana, rolling hills and plains rise up toward Cuba's northern coast to become the Sierra de los Órganos and Sierra del Rosario Mountains. The area's red to gray-brown soil has a high sand content, which provides good drainage, making it ideal for tobacco cultivation. Within this region was the famed Vuelta Abajo, an area approximately 81 miles long by 21 miles wide, bordered by Consolación del Sur, Mántua, the mountains to the north, and a line of palm trees that ran parallel to the southern coast. ${ }^{297}$ Countless nineteenth-century foreign visitors cited the Vuelta Abajo as containing the best tobacco in Cuba, with one even describing the area as "the promised land of the small planters of Kentucky and Virginia."298 Although other locations

297 . Thomas D. Boswell, "The West Indies: The Hispanic Territories and Haiti," in Middle America: Its Lands and Peoples, edited by Robert C. West and John P. Augelli, Thomas D. Boswell and et. al. (Englewood Cliffs, N.J.: Prentice Hall, 1989), 130, 134; Sintesis de geografia de Cuba (Miami, FL: Ediciones del Directorio Magisterial Cubano (en el exilio), n.d.), 19, 22; Fred A. Carlson, Geography of Latin America, 3rd (New York: Prentice-Hall, 1952), 443, 445; Samuel Hazard, Cuba with Pen and Pencil, reprint, 1871 (Miami: Editorial Cubana, 1989), 329.

298 . [William Henry Hurlbert], Gan-Eden: or, Pictures of Cuba. (Boston: John P. Jewett and Co., 1854), 109. For other travellers who expressed similiar sentiments about the Vuelta Abajo, see Abiel Abbot, Letters Written in the Interior of Cuba, Between the Mountains of Arcana, to the East, and of Cusco, to the West, in the Months of February, March, April, and May, 1828 (Boston: Bowles and Dearborn, 1829), 136; Maturin M. Ballou, Due South; or Cuba, Past and Present (Boston and New York: Houghton, Mifflin, 1885), 248; Joseph Judson Dimock, Impressions of Cuba in the Nineteenth Century: The Travel Diary of Joseph J. Dimock, edited by Louis A. Jr. Perez (Wilmington: Scholarly Resources, 1998), 92; Hazard, Cuba with Pen and Pencil, 329; Raymond A. Mohl, ed., "A Scotsman in Cuba, 1811-1812," The Americas 29, no. 2 (1972): 245. Manuel Moreno Fraginals argues that the claim that the Vuelta Abajo had world's best tobacco lands and tobacco was untrue, and just a method used to move 
throughout the island also focused on tobacco cultivation, the one most frequently associated with tobacco was Nueva Filipinas, today's province of Pinar del Río. ${ }^{299}$

Physically isolated from the rest of the island, the distance from the Cuyaguateje River, which traversed the region, to Havana was a grueling 60 leagues along primitive paths and over many streams. One high-ranking official described the territory as being without "an established town whatsoever, and all this vast terrain is reduced to haciendas (estates), estancias (cattle ranches) and ranchos (ranches), with a few thatched houses (casas de paja) built near the parochial churches for each district (partido)." 300 Without effective local governance, the area was not integrated into the island's political infrastructure and had become lawless and disorganized: Contraband in the tobacco industry was a particular concern as evidenced in a series of letters to the captain general. In less than a month on the job, tobacco monopoly inspector (visitador) Francisco Jacott wrote from San Juan y Martínez in 1773 stating that he had discovered tobacco hidden in

tobacco cultivation west, away from what was instead prime sugar-growing areas. Moreno Fraginals, El ingenio, 60.

299 . The area was known alternately as "Filipina," "Filipinas," and "Nueva Filipinas." Similiarly, Pinar del Río was usually known as "Pinal del Río" until the former won out. See Emeterio S. Santovenia, Pinar del Río (Mexico: Fondo de Cultura Economica, 1946), 93-94. For the purposes of this study, the term "Filipinas" will be used exclusively when referring to the jurisdiction, while "Filipina" will be used to refer to the town created.

300. Santovenia, Pinar del Rio, 53-54; Marqués de la Torre to Julián Arriaga, 22 January 1775, Havana, legajo 1220, PC, AGI, typescript copy in Archivo General de Indias, AGI, Documentos sobre Cuba 1740-1806, vol. 27, LM, SC, GL, FIU. 
"barbecues, small store rooms, chicken coops, and in some mountain-side ranches". 301

After successfully obtaining several vegueros' confessions, he was able to recover some tobacco. In the presence of local constable (capitan del partido) Nicolás Hidalgo Gato, Lieutenant (junior grade) Vicente Blanco, and a captain in the reformed militia, Juan de Mesa, Jacott informed the local tobacco farmers that they had 24 hours to turn in their tobacco. Houses and estates would be searched and any remaining tobacco would be confiscated. He repeated the order, he stated, to ensure that no one could claim ignorance. Just a few days later, Jacott complained that he was unable to find a single muleteer, although many had been around earlier when contrabanders frequented the coast, and requested that 300 animals be sent to the partido of Consolación. From there, they would be dispatched where most needed in order to transport tobacco to the Real Factoría in Havana. ${ }^{302}$

Soon, the situation had grown so severe, that "each day, the clamors of the disorder, injustice, and vexations of those inhabitants reciprocally caused by them, and suffered by the captains [constables] ...reach my ears...,"Cuba's captain general, Felipe Fondesviela, the Marqués de la Torre lamented. ${ }^{303}$ These concerns, combined with the

301. Francisco Jacott to Captain General, 4 September 1773, San Juan y Martínez, legajo 1220, PC, AGI, typescript copy in Documentos sobre Cuba 1740-1806, vol. 27, LM, SC, GL, FIU; Marreo, Azúcar, ilustracion y conciencia (1763-1868) (III), vol. 11 of Cuba: economía y sociedad, 41-42.

302 . Ibid.; Francisco Jacott to Captain General, 2 September 1773, Partido de San Juan y Martínez, legajo 1220, PC, AGI, typescript copy in Documentos sobre Cuba 17401806, vol. 27, LM, SC, GL, FIU.

303 . de la Torre to Arriaga, 22 January 1775, Havana, legajo 1220, PC, AGI, typescript copy in Documentos sobre Cuba 1740-1806, vol. 27, LM, SC, GL, FIU. 
desire to stem the tide of illegal commerce between both Cuban and foreign ships and the area's residents, led the captain general to suggest that the best way govern the jurisdiction was to formally found a town, separate it administratively from Havana, and place it under the control of a lieutenant governor (teniente gobernador) who would govern it in a manner similar to the system already existing in Trinidad, Puerto Príncipe, and other locations on the island. On July 23,1774 , de la Torre proposed the creation of a new western administrative jurisdiction containing six partidos between the Palacios River and the Cape of San Antonio. ${ }^{304}$

Cuba's captain general clearly was determined to make the plan succeed as demonstrated in his choice for the new lieutenant governor. Antonio Fernández, a captain in the Regiment of Americas Dragoons, had nearly 35 years in the military with a distinguished service record that included combat in Europe and North America. A perfect candidate for the job, the sixty-plus-year-old Fernández was a devoted military man who was descended from a military family and had embraced the "honorific career of the armed services since his infancy," he noted in a letter he wrote at the age of 80.305

304. Ibid.; Santovenia, Pinar del Río, 55-57. The partidos were Consolación del Sur, Consolación del Norte, Pinar del Río, San Juan y Martínez, Guane del Sur, and Guane del Norte, also known as Mantua.

305. Tte Col. Antonio Fernández, Capitan del Esquadron de Dragones de America Fixo de aquella Plaza, Memorial, 19 November 1788, Havana, expediente 36, legajo 6881, Secretaría del Despacho de Guerra (hereafter SGU), Archivo General de Simancas, Simancas, Spain (hereafter AGS); Antonio Fernández to unknown, 9 May 1793, Aranjuez, legajo 6851, expediente 1, SGU, AGS; Johnson, Social Transformation, 79. Fernández's daughter, Rafaela, continued the family's long association with the military when she married Manuel de Castilla. See Sherry Johnson, "'Señoras en Sus Clases no Ordinarias': Enemy Collaborators or Courageous Defenders of the Family?" Cuban Studies/Estudios Cubanos 34 (2004): 23-24. 
Fernández entered the army in his late twenties, and as a member of the Infantry

Regiment of Africa saw action in numerous battles in the Italian theater including the defense of the town of Chusanico, an attack on the trenches of Montalban, and the sieges of Dumon, Tortona, and Valencia del Po. During the battle of Plasencia, he defended the flag that he carried, never losing possession of it, even though he was trampled by enemy cavalry. His tenure in the Americas was also wrought with meritorious military service and more brushes with history. In 1762 , he became a cavalry lieutenant at the Saint Augustine, Florida garrison where he engaged in numerous encounters with the Indians, and was forced to leave behind two horses and several houses belonging to his wife when the territory was ceded back to Britain as part of the 1763 Treaty of Paris. ${ }^{306}$

By early 1775 , Fernández was dispatched to the area to begin serving at his new post. In an instruction dated January 16, de la Torre laid out Fernández's first duties. Among his first priorities were to establish the limits of the new territory, and inform the local capitanes del partido that they were subordinate to him in political and military matters, however, Fernández was to avoid interfering in internal matters of the local militia, which was under the jurisdiction of the island's military inspector general, de la Torre reminded. "Apply all of your attention to the laws, and keep watch over the conduct of said captains, and the other officials of the militia (compañias sueltas), so that they do not abuse their authority that they have by harming the vecinos (residents)...," de

306 . Fernández to unknown, 9 May 1793, Aranjuez, expediente 1, legajo 6851, SGU, AGS; Request for employment as lieutenant colonel (teniente coronel) of dragoons in Spanish army, Antonio Fernández, 5 July 1793, expediente 1, legajo 6851, SGU, AGS. 
la Torre ordered. ${ }^{307}$ Restoring law and order to the region was a key component of the teniente gobernador's responsibilities as indicated by de la Torre's directive to "pursue with firmness the evildoers" and "free your jurisdiction of the wickedness, risks and fears" that disturb the public order. ${ }^{308}$ Deserters from the veteran troops, fugitive criminals, vagrants, and other lawbreakers were specifically mentioned as deserving the lieutenant governor's attention. Filipinas's strategic location also meant that Fernández was on the front line against pirates and was ordered to alert the captain general to any ships that passed through the Cabo Corrientes at the southernmost tip of the new jurisdiction. ${ }^{309}$

Like other teniente gobernadores, a vital component of Fernández's responsibilities was to serve as district chief of the Intendant General of the Real Hacienda. This role placed him in charge of all matters related to the tobacco monopoly including ensuring that Havana's directives were followed. The excellent quality of the area's tobacco meant that preventing fraud, contraband and the illicit sale of tobacco was particularly important, de la Torre noted. In addition, Fernández was to make and receive

307 . [Marqués de la Torre], "Instruccion que ha de observar don Antonio Fernandez [sic] Capitan del Esquadron de Dragones de America en el empleo que se le ha conferido de Teniente Gobernador y Capitan a Guerra de Filipinas y su jurisdiccion," 16 January 1775, Havana, legajo 1220, PC, AGI, typescript copy in Documentos sobre Cuba 1740-1806, vol. 27, LM, SC, GL, FUU. Alfredo Dollero incorrectly states that Fernández was named to the post on November 2, 1775. See Adolfo Dollero, Cultura cubana (La provincia de Pinar del Río y su evolución) (Habana: Impresora Seoane y Fernández, 1921), 39.

308 . Ibid.

309 . Ibid., de la Torre to Arriaga, 22 January 1775, Havana, legajo 1220, PC, AGI, typescript copy in Documentos sobre Cuba 1740-1806, vol. 27, LM, SC, GL, FIU. 
payments for tobacco produced for the Real Factoria de Tabacos, sending all tobacco obtained from the local vegueros to Havana. ${ }^{310}$

Fernández's dedication to the Spanish crown did not end with his term as lieutenant governor of Filipinas. During the war with Great Britain (1779-1783), the loyal officer was called on to leave the island and defend Spain. Fighting under the command of Field Marshall Bernardo de Gálvez, Fernández participated in the attack and surrender of Mobile in the spring of 1780 , leading 25 dragoons and 30 free blacks through enemy territory as they traveled from New Orleans to the Bay of Olives, where he met up with members of Gálvez's army. He also participated in the siege and surrender of Pensacola which spelled the end of British control of West Florida. By time of his death around 1800 , Fernández had over 52 years of military service to the king including command of the San Carlos de la Cabaña fortress in Havana. ${ }^{311}$

310 . [de la Torre], "Instruccion que ha de observar don Antonio Fernandez...," 16 January 1775, Havana, legajo 1220, PC, AGI, typescript copy in Documentos sobre Cuba 1740-1806, vol. 27, LM, SC, GL, FIU.

311 . Joseph Alena, "Reglamento de Dragones de America, Relacion de los oficios del expresado Regto segun su antigudad en los empleos, que acutalmente obtienen con noticia de los anos de servicios, que tiene cada uno, campanas que ha hecho, y regto en que ha servido, antes de su colocacion en este," 22 July 1764, Havana, photocopy in Archivo General de Indias, AGI, Documentos sobre las milicias de Cuba (1764-1785), Audencia de Santo Domingo Legajo 2078, vol. 106, LM, SC, GL, FIU; Fernández to unknown, 9 May 1793, Aranjuez, expediente 1, legajo 6851, SGU, AGS; Request for employment as lieutenant colonel of dragoons in Spanish army, Fernández, 5 July 1793, expediente 1, legajo 6851, SGU, AGS; Victoriana Guillén, Widow's pension, expediente 105, legajo 7232, SGU, AGS; Unknown to Governor of Santo Domingo, 3 December 1794, San Lorenzo, expediente 56, legajo 7151, SGU, AGS. Fernández's devotion to his post was evident in failure to request permission to return to Spain. By 1791, it had been 31 years. See "Informe," 23 December 1791, Havana, expediente 56, legajo 7151, SGU, AGS. For the Mobile and Pensacola campaigns, see Kuethe, Cuba, 1753-1815, 104-10; William S. Coker, "Diaster to Victory: The Reign of Charles III and Its Effect Upon $L a$ 
The site for the new town (pueblo), to be named Filipina, was given careful thought. Although de la Torre advised that the location should have healthy winds, access to raw materials for construction, and be along the banks of the Cuyaguateje River, since it was marked the center of the new jurisdictional area, Fernández could choose the locale he deemed most appropriate. ${ }^{312}$ Engineer Francisco Gelabert was dispatched to the area to assist in choosing the final site. Land located along the Carrera de los Vegueros was on higher ground and offered ample access to good soil for bricks and a forest which could provide lumber. Unfortunately, however, it was nearly half a league (approximately 1.5 miles) from the Cuyaguateje River where the area's vegas were located. The new town was "principally for the development of tobacco," Gelabert the noted, and it was best if the town was located closer to the tobacco farms. ${ }^{313}$ Another location considered was known as the Paso de los Ciegos along the Cuyaguateje River and had abundant access to potable water, construction materials, and healthy winds. Gelabert noted that because it was situated amongst the existing 24 vegas, it would be easier for the teniente gobernador to oversee the tobacco farmers' activities. Gelabert commented that another 48 or perhaps 100 vegas could be opened in the area, but

Florida, "in Charles III: Florida and the Gulf (Coral Gables, Florida: Count of Gálvez Historical Society, 1990), 25-28. Fernández's devotion to his post was evident in failure to request permission to return to Spain. By 1791, it had been 31 years. See "Informe," 23 December 1791, Havana, expediente 56, legajo 7151, SGU, AGS.

312. Ibid.

313 . Francisco Gelabert, "Relación del reconocimiento de las orillas del Rio Quayaguatexe [sic]," 12 July 1776, Havana, typescript copy in Archivo General de Indias, AGI, Documentos sobre Cuba 1740-1806, vol. 27, LM, SC, GL, FIU. 
unfortunately, the land available for the new pueblo was limited and, as a result, the size of the town would be limited to only 200 solares (a circular plot of ground typically found in colonial real estate). No one will move to this location, Gelabert stated, "whose interest is not founded in tobacco farming, as it is the only enterprise that will provide a living for them, since that land according to practice and time" demonstrated that it was only suited for the cultivation of tobacco.314

Miguel de Peñalver, a junior alderman (teniente de regidor) and district magistrate of Havana province (alcalde mayor provincial de La Habana) owned the Francisco Xavier de Sansueña, and Río Frío haciendas located in the area where the new town was proposed. He offered to present the land to the Crown, along with financing half of the cost of the official government buildings, and donate all of the wood necessary to construct the town's first houses. In return, Peñalver requested a title of Castile, and asked to be named the town's mayor (alcalde mayor de la Santa Hermandad). Although Peñalver was not recognized as the sole founder of Filipina, he received a title of Castile in recognition for his contributions. ${ }^{315}$

Even into the nineteenth century, Filipinas remained largely isolated from the rest of the island. By 1819, the region had just one pharmacy, a doctor and four schools, two

\section{Ibid.}

315. de la Torre to Arriaga, 22 January 1775, Havana, legajo 1220, PC, AGI, typescript copy in vol. 27, LMC, SC, GL, FIU; Antonio Fernández to Marqués de la Torre, 28 February 1775, Filipinas, legajo 1180, PC, AGI; Dollero, Cultura cubana, 39; Santovenia, Pinar del Rio, 56-57, 60-61; Leví Marrero, Azúcar, ilustración y conciencia (1763-1868) (III), vol. 11 of Cuba: economía y sociedad (Madrid: Editorial Playor, 1984), 15. More on Peñalver's involvement with the area's tobacco industry will be discussed later in this chapter. 
for boys and two for girls, with most facilities concentrated in either Pinar del Río or

Guane. Although there were no established parishes, thirteen churches served the religious needs of the population of just over 13,000. The region became somewhat less isolated with the establishment of mail service in 1834 , while maritime communications with Havana started in 1841 via the steam lines of Empresa Bustamonte, Cajigal and Company. ${ }^{316}$

\section{The Importance of Tobacco}

Tobacco's affiliation with this area was long-standing. One author argues that many of the vegueros who participated in the tobacco uprisings of the early eighteenth century left the countryside near Havana and relocated in the Vuelta Abajo. ${ }^{317}$ Over a decade and a half before Filipinas became its own separate jurisdiction, tazmias detail importance and vibrancy of the area's tobacco industry. In the Guane district in 1760, more than 120,000 manojos (bundles) were turned in to royal authorities by 56 individuals responsible for growing tobacco. Ten years later in the partido of San Rosendo de Pinar del Río alone, 68 vegueros and tobacco farms employed 97 people and produced just over 18,000 cujes (sticks) of tobacco. ${ }^{318}$ The new jurisdiction's tobacco

316. Dollero, Cultura cubana, 40-41; Kenneth F. Kiple, Blacks in Colonial Cuba 1774-1899, Latin American Monographs, 2nd Series (Gainesville: University Presses of Florida, 1976), appendix, census of 1817.

\section{Santovenia, Pinar del Río, 43.}

318. Juan Tio, "Noticia del tavaco en Rama del Partido de Guanes que se ha recogido, segun he manifestado en esta RI Fuerza, a saver," 13 May 1760, Havana, legajo 2016, SD, AGI; Francisco de Paula Mari, "Tasmia de los Tabacos del Partido de Sn 
industry was presented with early obstacles, particularly a 1775 prohibition against new vegas, similarly repeated in other locations throughout the island. ${ }^{319}$ Nevertheless, by mid-June of 1775, new lieutenant governor Antonio Fernández replied to Havana that a tally of the six partidos that comprised the new jurisdiction revealed 120 vegas worked by 107 people and producing 35,167 cujes of tobacco for the royal monopoly. 320

Tobacco's role as the region's predominant agricultural enterprise was fully established as cultivation expanded during the 1770s and 1780s. The Vuelta Abajo in 1782 contained a total of 93 vegas and 98 individuals who were listed on that year's tazmia as responsible for growing tobacco. All of those listed as vega owners were responsible for just one farm, with the exception of one man, Lieutenant (junior grade) José Manuel Rodríguez who owned two vegas. Together, these farms employed 149 people and produced 14,898 cujes of tobacco. Most vegas, or 57 percent, were worked by just one individual, possibly the person listed as the owner, while almost 27 percent of vegas were tended by a veguero and one other person. ${ }^{321}$ The following year, there were

Rosendo del Pinal del Río a la respectiva cosecha del año de 1770," 2 June 1770, Pinar del Río, legajo 1094, PC, AGI.

319 . Antonio Fernández to Marqués de la Torre, 21 April 1775, Filipinas, legajo 1180, PC, AGI; José Morejon to Marqués de la Torre, 5 April 1775, Batabanó, legajo 1194, PC, AGI; Marqués de la Torre to Ambrosio Pérez Baes, 12 May 1775, Havana, legajo 1193, PC, AGI; Manuel del Portillo to Marqués de la Torre, 13 June 1775, Sancti Spiritus, document 79, legajo 1185, PC, AGI.

320. Antonio Fernández, "Tazmia hecha pr los Diputados de esta Jurisdiccion de los Tabacos qe se hallan cogidos en la cosecha del presente año de 1775," 11 June 1775 , Filipina, legajo 1180, PC, AGI.

321. Gabriel de Mier, "Tazmia correspond ${ }^{\text {te }}$ a los Partidos de la Buelta de Abajo en que comprehende el numero de Vegas, sus Dueños, operarios que las cultivan, y los 
July of 1787 , Filipinas contained 232 vegas, compared to 98 hatos (cattle farm), 54 corrales (small estates), 3 sitios (small subsistence or pig farm) and just one ingenio (sugar plantation). A tally taken just six months later may have been more thorough, particularly in two districts, as the number of tobacco farms had risen substantially in such as short time, now up to 270 , while 128 hatos, 44 corrales, two sitios, and one ingenio were listed. Four of the six districts saw an increase in the number of tobacco farms over the previous count, with Filipinas and Pinar del Río showing the greatest growth, up to 40 from 29 , and 84 from 70 , respectively. Only one partido, San Juan y Martínez, experienced a decrease, a virtually negligible loss of just one vega, dropping from 49 to 48 , while the number of tobacco farms in Consolación del Norte remained unchanged at 9.323 By 1791 , Los Palacios, located slightly less than halfway between

Cujes que cada uno tiene dentro de sus Casas a saver," 15 June 1782, Filipina, legajo 1317, PC, AGI. Two properties worked by two slaves each, belonging to Thomasa Lorenzo and the Padres de Belen respectively, were not included in the calculations as being worked by those listed as "owner."

322. Gabriel de Mier, "Tazmia correspondiente a algunos Parts de la Buelta de abajo, o Sotavento, de los de mi cardo, en que comprehende las vegas de tavaco, los Dueños, operarios que las cultiban, y los cujes que cada uno tiene dentro de sus Casas a saver," 11 June 1783, Filipina, legajo 1350, PC, AGI; Gabriel de Mier, "Tazmia correspondiente a algunos Partidos de la Buelta de abajo o Sotavento que se me han hecho cardo, en que comprehende las vegas de tavaco, los Dueños, operarios qe las cultivan, y los Cujes que cada uno tiene dentro de sus Casas a saver," 11 June 1783, Consolación, legajo 1350, PC, AGI.

323 . Francisco Xavier de Lamadriz, "Resumen general de todas moradores, con distincion de clases, colores, edades, y sexos: de las haciendas, casas, Iglesias, y demás que comprehende la Jurisdiccion de la Nueva Filipina, correspondiente a este año de 1787," 1 July 1787, Pinal del Rio, legajo 1407, PC, AGI; Ramón de Villera, "Resumen general de todas moradores, con distincion de clases, colores, edades, y sexos; de las 
Pinar del Río and Havana, had nearly twice the number of tobacco farms as any other agricultural pursuit and no ingenios at all. ${ }^{324}$ At the end of the eighteenth century, 478 tobacco farms in the Vuelta Abajo alone covered nearly 177 caballerías, or about 5,894 acres, and employed 799 people. ${ }^{325}$ In the final year of the monopoly, 1817, all of the 793 vegas located in Havana Province were concentrated exclusively in Filipinas, and 2,015 people, or 15 percent of the area's total population, were engaged in tobacco production. Yet, the tobacco industry could undergo further expansion, monopoly officials noted, since there was available land for an additional 409 vegas. ${ }^{326}$

Tobacco remained a vital component of life in Filipinas even after the abolition of the tobacco monopoly in 1817 . With no regulations on its production, cultivation in Filipinas expanded significantly, just as it did in other parts of the island. By 1827 , approximately 46 percent of Cuba's 5,534 vegas were located in Occidente (the western department), an area that included Filipinas and the famed Vuelta Abajo, while the remainder were divided between the central ( 25 percent) and eastern ( 29 percent)

Haziendas, Casas, Iglesias, y demas que comprehende esta Jurisdiccion de la Nueba Poblacion de Filipina, correspondiente a el Año de 1788," 1 April 1788, Pinal del Río, legajo 1707, PC, AGI.

324. Relacíon, Palacios, 10 octubre 1791, PC 1472, AGI.

325. Marrero, Azúcar, ilustración y conciencia (1763-1868) (III), vol. 11 of Cuba: economía y sociedad, 15.

326 . José Gonzalez, "Plan demostrativo de todas las tierras que acutalmente hay destinados al cultivo de tabacos en cada partido de la isla de Cuba...," 31 May 1817, Real Factoría de Tabacos, La Habana, legajo 2019, SD, AGI; Ramiro Guerra y Sánchez, José M. Pérez Cabrera, Juan J. Remos, and Emeterio S. Santovenia, Ilustración libertad de comercio (desde 1790 hasta 1837), vol. 3 of Historia de la nación cubana (La Habana: Editorial Historia de la Nacion Cubana, 1952), 346. 
departments. 327 The number of farms growing tobacco only continued to increase over the next few decades, and by 1846 , nearly 44 percent of all vegas on the island, 3,990, were located in this region. ${ }^{328}$ Yet, the tobacco vega was not merely important to Filipinas for its contribution to the area's agricultural sector alone, but also served as home to thousands of rural residents. The vast majority, an overwhelming 87.6 percent, or just under 32,500 people, of Filipinas' (now known as Nueva Filipinas) 1846 rural population lived on vegas, as compared to only 17 percent, or 71,319, of Cuba's overall rural residents. In the partidos of San Juan y Martínez and Consolación del Sur, nearly the entire population lived on vegas. ${ }^{329}$ As the nineteenth century drew to a close, tobacco cultivation further grew. While there were 3,616 tobacco farms in the region in 1862, by 1880 the figure had increased to 4,000 , and in 1894, Nueva Filipinas was home to more than 6,000 vegas, a rise of nearly 66 percent in 32 years. For Filipinas, the period from the opening of free trade in tobacco in 1817 to the end of the nineteenth century

327. Ramiro Guerra y Sánchez, Sugar and Society in the Caribbean: An Economic History of Cuban Agriculture, with a foreword by Sidney W. Mintz, Caribbean Series (New Haven and London: Yale University Press, 1964), 49; Guerra y Sánchez, Pérez Cabrera, Remos, and Santovenia, Ilustración libertad de comercio (desde 1790 hasta 1837), 178.

328 . Alexander Humbolt, The Island of Cuba, translated by J.S. Thrasher (New York: Derby and Jackson, 1856), 280.

329 . Marrero, Azucar, ilustración y conciencia (1763-1868) (III), vol. 11 of Cuba: economía y sociedad, 60-61. The percentage of rural residents living on tobacco farms in San Juan y Martínez and Consolación del Sur were 97.4 and 94.3 respectively. In another volume, Marrero argues that there were just 4.7 percent of Cuba's total rural population residing on vegas in 1846. See Marrero, Azucar, ilustración y conciencia (1763-1868) (I), vol. 9 of Cuba: economia y sociedad, 207. Based on calculations of both the actual population numbers and corresponding percentages found in volume 11 , the first citation appears to be the more accurate one. 
marked an explosion in the number of vegas found in the area, with an astounding 657 percent growth in farms dedicated to tobacco cultivation. ${ }^{330}$

\section{A Difficult Life for Filipinas" "Buena Gente"}

Forces of nature played a significant role on the region's tobacco industry, particularly when it deviated from the norm. While eastern Cuba, also known as Oriente, typically received 40 to 50 inches of rainfall per year, the island's highest amounts, around 60 or 70 inches, fell in the western part of Filipinas and the areas south of Havana. ${ }^{331}$ If it fell at the right time, rain was a boon for the region's farmers, but if it did not, it could spell disaster to the year's crop. Filipinas' rivers frequently overran their banks and threatened the nearby tobacco farms. Early rains and flooding of the area's rivers left the surrounding vegas under "more than a vara (yard) of water," and negatively impacted the 1775 harvest, new lieutenant governor Antonio Fernández noted in a letter he enclosed along with the annual tazmia. ${ }^{332}$ Floods continued to plague Filipinas' vegueros. After three days of rain, on April 10, 1779, between 3 and 4 in the afternoon, area rivers overran their banks. The water covered the area's vegas, as well as the corn

330 . González, "Plan demostrativo de todas las tierras...," 31 May 1817, Real Factoría de Tabacos, La Habana, legajo 2019, SD, AGI; Dollero, Cultura cubana, 31819; William J. Clark, Commercial Cuba: A Book for Business Men (New York: Charles Scribner's Son, 1898), 248.

331. Carlson, Geography of Latin America, 442.

332. Antonio Fernández to Marqués de la Torre, 20 June 1775, Filipinas, legajo 1180, PC, AGI; Antonio Fernández to Marqués de la Torre, 25 June 1775, Filipinas, legajo 1180, PC, AGI. 
and rice plots, prompting one local official to state that although "it is necessary to conform to the will of God...these poor inhabitants do not need such misfortune since they are so unhappy, as it is much misery in which they live..." 333

While normal rainfall events could cause significant damage to the area's tobacco industry, frequent hurricanes brought only more destruction. Historically, most hurricanes impacting Cuba struck the western portion of the island, and while Havana had a 20 percent probability of the storm affecting the capital, Filipinas had the highest risk at 38 percent. Between 1763 and 1817, the period covered by this study, no less than nine hurricanes struck western Cuba. ${ }^{334}$ Storms occasionally came in close succession, bringing additional damage and flooding to areas already hard hit by earlier cyclones. Five consecutive days of "continuous rain" in mid-October 1774 caused the normally low Cuyaguateje River to rise to a "formidable level that has not been seen in many years," the capitan del partido wrote from Guane del Sur, and was followed by a hurricane which brought additional precipitation beginning around 9 o'clock on the night of October 31 , and continuing throughout the following day. ${ }^{335}$ Depending on the hurricane's track, PC, AGI.

333 . Ramón Lloret to Diego José Navarro, 12 April 1779, Filipina, legajo 1261,

334 . Julio Le Riverend Brusone, La Habana, espacio y vida (Madrid: Editorial MAFRE, 1992), 23; Carlson, Geography of Latin America, 443; Louis A. Pérez, Jr., Winds of Change: Hurricanes and the Transformation of Nineteenth Century Cuba (Chapel Hill: University of North Carolina Press, 2001), 31-32; Dollero, Cultura cubana, 33.

335 . For both quotes, see Miguel Guerrero to Marqués de la Torre, 19 November 1774, Partido de Guane al Sur, legajo 1180, PC, AGI. For description of Cuyaguateje River, see Gelabert, "Relación del reconocimiento...," 12 July 1776, Havana, typescript copy in Documentos sobre Cuba 1740-1806, vol. 27, LM, SC, GL, FIU. 
impact on the jurisdiction varied greatly as demonstrated by a wind and rain storm,

possibly a hurricane, which caused local rivers to overrun their banks, bringing

devastation to the partidos of Guane del Sur and Guane del Norte (also known as

Mantua), while local officials in Consolación del Sur and San Juan y Martínez reported

that luckily there were no losses in their locations. ${ }^{336}$ Severe damage to the area's

agricultural interest was not limited to the cyclone's land fall, however. On October 8,

1846, as the San Francisco de Borja storm approached the island from the southeast

before it would pass over the capital, Havana's Diario de la Marina published a letter

from a resident in Guane describing the damage already caused by the hurricane.

It is impossible for me to communicate the details

concerning the lamentable effects of the rains of

September...It has rained without stopping a single moment

for days and nights. The rivers have swollen to menacing

proportions, the roads have become impassable. Tobacco

farmers have lost almost everything. ${ }^{337}$

As noted elsewhere in this study, the historiography describing Cuban vegueros as poor whites who engaged in small-scale tobacco cultivation predominates the existing scholarship of colonial Cuba. ${ }^{338}$ While an earlier chapter demonstrates that this image is

336. Guerrero to de la Torre, 19 November 1774, Partido de Guane al Sur, legajo 1180, PC, AGI; José Perez to Marqués de la Torre, 21 November 1774, Pinar del Río, legajo 1180, PC, AGI; Domingo Duarte to José Perez, 19 November 1774, Consolación del Sur, legajo 1180, PC, AGI.

337 . Pérez, Louis A., Jr., Winds of Change, 69; Jorge Macle Cruz, "La tormenta de San Francisco de Borja," Boletín del Archivo Nacional 12 (2000): 108.

338 . See, among other examples, Ortiz, Cuban Counterpoint, 56-57, 59, 82, 87; Santovenia, Pinar del Río, 91; Guerra y Sánchez, Pérez Cabrera, Remos, and Santovenia, Ilustración libertad de comercio (desde 1790 hasta 1837), 50; McNeill, Atlantic Empires of France and Spain, 116, 254; Klein, Slavery in the Americas, 49. 
only partly complete, revealing that the veguero population island wide was much more heterogeneous than currently described, there were some tobacco farmers in western Cuba who did fit the description made famous by Fernando Ortiz and others. Natural disasters such as those mentioned above only added to the misery of some of the area's tobacco farmers, who frequently described in correspondence between local officials in western Cuba and Havana during the years of 1767 and 1768 as poverty-stricken and unable to feed their families. ${ }^{339}$ A hurricane that passed over western Cuba in October 1768 only worsened the situation by damaging the tobacco crop, thereby having a negative effect on the vegueros' livelihood. The Guane district's tobacco production declined sharply during this period, dropping from 1,905 arrobas (equivalent to about 25 pounds) in 1767 to just 479 the following year, although they recovered slightly to 1,223 arrobas in 1769. It was not until 1770 , however, that the region's harvest returned to the same levels it had been in $1766,3^{340}$ A closer look at the difficulties faced by the area's vegueros in providing sustenance for his family reveal that the problem appeared to be less related to a question of finances, and instead attributable to local supply issues.

Lack of meat was a frequent complaint made by Filipinas' tobacco farmers. As early as the spring of 1768 , Tomás de la Luz informed Havana that the region's vegueros

339 . Nicolás Hidalgo Gato to Antonio María Bucareli, 9 October 1767, San Juan y Martínez, legajo 1093, PC, AGI; José Cipriano to Antonio María Bucareli, 11 January 1768, San Juan y Martínez, legajo 1093, PC, AGI; Nicolás Hidalgo Gato to Antonio María Bucareli, San Juan y Martínez, 11 January 1768, legajo 1093, PC, AGI.

340. Dollero, Cultura cubana, 33; Pérez, Louis A., Jr., Winds of Change, 31; Sherry Johnson, El Niño's Atlantic World. For tobacco production, see Manuel Ramires de Arellano, "Estado que manifiesta los Tabacos que han entregado los Labradores de este fruto en la Factoría general de la Havana...," 4 August 1804, Havana, table 9 , signatura 9454, legajo 209, Real Consulado y Junta de Fomento (hereafter RC), ANC. 
did not have sufficient meat supplies to feed their families. ${ }^{341}$ The rural population either raised their own livestock, or attempted to buy it from local hacendados (cattle ranch owners). By the mid-1770s, despite the creation of a separate jurisdiction and a direct line to the seat of power in Havana through a newly-created local government, the situation remained unchanged. Not long after he arrived in his new post, teniente gobernador Antonio Fernández wrote to Cuba's captain general, the Marqués de la Torre, "I see their unhappiness when they do not find someone in any hacienda (ranch) to sell an arroba of meat to them." 342 Ranches refused to sell to the local vegueros, but provided meat to others as evidenced by the foreman of the hacienda San Julian who sold two arrobas of meat to a ship that had insufficient supplies to set out on its voyage. During the Easter holiday of 1775, Fernández visited Guane del Sur, located on the far southwestern coast, reported that the residents there were "buena gente" (good people), but suggested that something be done to help the poor vegueros. ${ }^{343}$ Nevertheless, the problem of a lack of meat remained an issue for these western farmers even into the next decade.

In 1780 , one of the vegueros' elected representatives in matters related to the tobacco monopoly, known as a diputado, don Nicolás Ramos and ten other vegueros from the Filipinas district personally wrote to local government officials and requested assistance. Noting their service to the Spanish Crown, they pleaded in their letter, “...we serve the King....with our labors and ourselves...we are ready if the enemy lands on these

341 . Tomas de la Luz to Antonio María Bucareli, 25 May 1768, Pinar del Río, PC 1093, AGI.

342. Antonio Fernández to Marqués de la Torre,13 March 1775, Filipinas, legajo $1180, \mathrm{PC}, \mathrm{AGI}$.

343 . Ibid., Antonio Fernández to Marqués de la Torre, 29 April 1775, Filipinas, legajo 1180, PC, AGI. 
coasts ..."344 Ramón Lloret forwarded the letter on to Captain General Diego José

Navarro, and noted that some vegueros told him that without meat to eat they were inclined to "leave the country, because it is nothing unusual that they, their wives and children could die from hunger..." 345 Lloret continued,

what am I to do with a veguero with a family, who after having gone to all of the hatos and corrales of this jurisdiction carrying his money in his hand (and this Sir, because I, from my own pocket, knowing his necessity made the charitable act of loaning it to him) with the hope of that someone will sell him a cow or pig, finds no one who will sell him a pound of meat... ${ }^{346}$

Navarro may have been sympathetic to the tobacco farmers' plight, but noted that the ranch owners could not be required to sell meat to the tobacco farmers, particularly at the established prices. ${ }^{347}$ The situation remained unresolved through that fall and winter, and by May 1781, the lieutenant governor of Filipinas, Gabriel de Mier, again wrote to the captain general, reporting that local vegueros were in desperate need of meat. After pondering the situation, de Mier commented that there was only one remedy, namely the

344. Nicolas Ramos, Nicolas Hernández, Alejandro Sanches, et. al. to Teniente de Gobernador, Filipinas, [no date], legajo 1261, PC, AGI.

345 . Ramón Lloret to Diego José Navarro,31 May 1780, Filipina, legajo 1261, PC, AGI.

346 . Ibid. This passage reads as follows: “...que tengo que hazer con un Hombre Veguero, con familia que despues de haver corrido todos los Hatos, y Corrales de esta Jurisdiccíon, a fín de que le vendan una res, o un serdo, llevando su dínero en la mano (y esto Sor porque Yo de mí bosillo, por conocer su nesecidad, les hago la caridad de prestarselo) no encuentra quíen le Venda una Libra de Carne..."

347 . Diego José Navarro to Gabriel de Mier, 26 August 1780, Havana, legajo 1261, PC, AGI. 
establishment of slaughter houses offering small livestock in each district seat. This time the request was met with a positive response when Navarro gave his approval for the sale of "up to a pound of meat daily at equitable or wholesale prices" for a period of four months. ${ }^{348}$ Nevertheless, as late as 1805 , the scarcity of available meat still plagued the area. From the San Cristobal River to Mantua, virtually the entire Filipinas region, there was no butcher from whom the vegueros or other residents could purchase meat. 349

\section{Tobacco's Chosen People}

While Filipinas and its residents suffered from economic problems partially related to forces of nature and the disasters that ensued, it is inaccurate to describe the area's vegueros as being comprised almost exclusively of one group of people, specifically poor, white, Canary Islanders. ${ }^{350}$ This thesis is not only false, but leads to an oversimplified view of life in eighteenth- and nineteenth-century Filipinas. Data collected and cross-

348 . Gabriel de Mier to Diego José Navarro, 9 May 1781, Filipinas, legajo 1317, PC, AGI; Diego José Navarro to Gabriel de Mier, 11 June 1781, Havana, legajo 1317, PC, AGI.

349 . “...todos los oficios de D. José María de la Torre,” report and attachments, 12 March 1805, legajo 2018, SD, AGI.

350 . Ortiz, Cuban Counterpoint, 59; Ramiro Guerra y Sánchez, José M. Pérez Cabrera, Juan J. Remos, and Emeterio S. Santovenia, Guerras coloniales conflictos y progresos (desde 1697 hasta 1790), vol. 2 of Historia de la nación cubana (La Habana: Editorial Historia de la Nacion Cubana, 1952), 153; Klein, Slavery in the Americas, 148; Julio le Riverend, Historia económica de Cuba (Barcelona: Ediciones Ariel, 1972), 14344; Pablo Tornero Tinajero, "Inmigrantes canarios en Cuba y cultivo tabacalero. La fundación de Santiago de las Vegas," in IV Coloquio de historia canario-americana (1980), vol. 1 (Gran Canaria, 1982), 505-30; Antonio M. Macías Hernández, La migración canaria, 1500-1980 (Colombres, Spain: Ediciones Júcar, 1992), 124-25. 
referenced from the area's censuses (padrones), tazmias, and notary records indicate that Canary Islanders represented a small proportion of those residing in Filipinas. A 1786 padron reveals that in five of the area's six partidos, slightly less than 5 percent, or 13 out of 272 heads of households, were from the Canary Islands. The greatest concentration of households headed by isleños was in the San Juan y Martínez district (7 out of 63), followed by Guane del Sur (4 out of 59), Consolación del Sur (1 out of 36), and Pinar del Río (1 out of 114), while none lived in Guane del Norte. ${ }^{351}$

Yet, how many Canary Islanders living in Filipinas were also vegueros? The percentage seems particularly low if only the 18 tazmias collected from the region are consulted since just one individual specifically described as a Canary Islander is listed. In 1782 , the tazmia from the eastern most edge of the new jurisdiction, the Los Palacios

351 . Pedro Antonio Gallo, "Noticia de los Vecinos que comprhenden el Partido de Guane del Norte y como Capitan doy al Senor Governador y Capitan General con arreglo a su orden de 31 de Marzo de 1786," 15 April 1786, Guane del Norte, photocopy in AGI, AHN, Cuba, Poblacion, 1766-185I, volume 119, LM, SC, GL, FIU; unsigned, "Noticia de los Vecinos que comprehende el Partido de Sn Juan y Martines, y como Capn de el, doy al Sr Govor y Capn Gral con arreglo a su orden de 31 de Marzo de 1786," not dated, location unknown, legajo 1704, PC, AGI, photocopy in AGI, AHN, Cuba, Poblacion, 1766-1851, volume 119, LM, SC, GL, FIU; Luis Dias Pimienta, "Noticia de los Vezinos que comprehende el partido de Guane del Sur y como capitan doy al Senor Gobernador y Capitan General con arreglo a su orden de tienta y uno de Marzo de mil setecientos ochenta y seis," 20 April 1786, Partido de Guane del Sur, photocopy in AGI, AHN, Cuba, Poblacion, 1766-1851, volume 119, LM, SC, GL, FIU; Antonio Martines, "Noticia de los Vezinos qe comprehende el Partido de Consolacion del Sur y como Subtente del pr acuerdo del Capn y Tte doy al Sor Governor y Capn General con arreglo a su orn de 31 de Marzo de 1786," 27 March 1786, Consolacion del Sur, photocopy in AGI, AHN, Cuba, Poblacion, 1766-1851, volume 119, LM, SC, GL, FIU; Mariano Murquia, "Noticia de los Vezinos que comprehende el Partido de Pinal del Rio y como Capn doy al Sor Governor y Capn Gral con arreglo a su orn de 31 de Marzo de 1786," 26 April 1786, Pinal del Rio, photocopy in AGI, AHN, Cuba, Poblacion, 1766-1851, volume 119, LM, $\mathrm{SC}, \mathrm{GL}, \mathrm{FIU}$. 
district, noted that Nicolás el isleño owned a tobacco farm. While other vegueros in the partido worked alone, he had one person helping him in his fields, yet he managed to produce just 100 sticks of tobacco. Despite additional labor, his yield paled in comparison to that of Francisco Crespo who delivered 600 cujes of tobacco to the royal monopoly, leaving Nicolás and another veguero, Matias García, tied for a distant second place. Tobacco cultivation in Los Palacios, however, was nominal with five tobacco farms employing a mere six individuals and producing a paltry 900 sticks of tobacco for the royal monopoly. In contrast, nearby Consolación boasted 25 vegas and 50 tobacco workers, and produced 4,415 cujes of tobacco. ${ }^{352}$ A truer representation of the number of

352. Tio, "Noticia del tavaco en Rama del Partido de Guanes...," 13 May 1760 , Havana, legajo 2016, SD, AGI; Nicolás Hidalgo Gato, "Tasmia de los Tavacos del Partido de Sn Juan y Martines respectiva a la Cosecha de 1770, Partido del Norte," 10 April 1770, San Juan y Martínez, legajo 1094, PC, AGI; Tomás de Sierra, "Tazmia de los tabacos de el partido de Guane en la Costa de el Norte y Rio de Manuta Respectiva a la Cosecha de este año de 1770," Habarro, 1 May 1770, legajo 1094, PC, AGI; Francisco de Paula Mari, "Tasmia de los Tabacos del Partido de Sn Rosendo del Pinal del Río a la respectiva cosecha del año de 1770," 2 June 1770, Pinar del Río, legajo 1094, PC, AGI; Mathias Joseph Duarte, "Tasmia de los Tabacos de Partido de Sn Ildefonso de Guane respectiva a la Cosecha de 1770," 6 June 1770, San Ildefonso de Guane, legajo 1094, PC, AGI; Domingo Duarte, "Tazmia de los tavacos del Partido de Consolación, uno de los de la parte de Sottoto del Puerto de la Hava respectiva a la Cosecha del año de 1770," [no date], Consolación, legajo 1094, PC, AGI; Nicolás Hidalgo Gato, "Tasmia de los Tavacos del Partido de Sn Juan y Martines respectiva a la Cosecha de 1770, Partido del Sur," 22 June 1770, San Juan y Martínez, legajo 1094, PC, AGI; Nicolás Hidalgo Gato, "Tasmia de los Tabacos del Partido de Sn Juan respectibe a la Cosecha de 1771," 27 March 1771, San Juan y Martínez, legajo 1096, PC, AGI; Francisco de Paula Mari, "Tasmia de los Tabacos de Partido de Pinal del Rio de la Cosecha de 1771," 29 May 1771, Pinar del Rio, legajo 1096, PC, AGI; Manuel del Castillo, "Relasion de las Vegas que se han Cultivado tavacos, en el presente año en el reio de Cuiaguatexe con individualidad de los Sujectos, Cujes y Manojos que pueden produsir," 30 May 1771, Cuiaguatexe, legajo 1096, PC, AGI; unsigned, "Tasmia de los tabacos del Partido de San Juan y Martines respectiva a la cosecha de 1772," no date, no location, legajo 1180, PC, AGI; Ramón Lloret, "Tasmia correspondiente al Partido de Sn Juan y Martines de la Buelta de avajo, o sotavento que se me a echo cargo, en que comprehende las Vegas de Tavaco, los Dueños, Operarios que 
Canary Islanders who were also tobacco farmers, however, is gleaned from a comparison

of the 13 isleño heads of households to tazmia lists and real estate records. Such crossreferencing of names of known tobacco farmers reveals that 8 out of the 13 isleño heads of households were also vegueros. Slightly less than half of these lived in the partido of San Juan y Martínez, while 2 called Guane del Sur home, and the other lived in Pinar del Río.353

As was the case throughout the island, demonstrated in Chapter 3 of this study, the tobacco farmers living in the far western part of Cuba were drawn from all sectors of

las cultivan, y los Cujes que cada uno tiene dentro de sus casas a saver," 1 June 1779, San Juan y Martínez, legajo 1261, PC, AGI; Ramon Lloret, "Tasmia correspondiente a algunos Partidos de la Buelta de abajo, o Sotavento en que se comprehenden las vegas de tabaco, los dueños operarios que las cultivan y los cujes que cada uno tiene dentro de sus casas a saber," 24 April 1780, Filipina, expediente 156, folio 228v, legajo 1261, PC, AGI; Bernardo Romero, "Tazmia correspondiente a algunos Partidos de la Buelta de abajo o sotavento que se me han hecho cargo, en que comprehende las vegas de tavaco, los Dueños, operarios que las cultivan, y los Cujes que cada uno tiene dentro de sus casas a saver," 20 June 1781, Consolación del Sur, legajo 1317, PC, AGI; Gabriel de Mier, "Tazmia correspondiente a algunos Partidos de la Buelta de abajo o sotavento que se me han hecho cargo, en que comprehende las vegas de tavaco, los Dueños, operarios que las cultivan, y los Cujes que cada uno tiene dentro de sus casas a saver," 20 June 1781 , Filipina, legajo 1317, PC, AGI; Gabriel de Mier, "Tazmia correspondiente a los Partidos de la Buelta de Abajo en que comprehende el numero de Vegas, sus Dueños, Operarios que las cultivan, y los Cujes que cada uno tiene dentro de sus Casas a saver," 15 June 1782, Filipina, legajo 1317, PC, AGI; Gabriel de Mier, "Tazmia correspondiente a algunos Partidos de la Buelta de abajo o sotavento que se me han hecho cargo, en que comprehende las vegas de tavaco, los Dueños, operarios que las cultivan, y los Cujes que cada uno tiene dentro de sus casas a saver," 11 June 1783, Filipina, legajo 1350, PC, AGI; Bernardo Romero, "Tazmia correspondiente a algunos Partidos de la Buelta de abajo o sotavento que se me han hecho cargo, en que comprehende las vegas de tavaco, los Dueños, operarios que las cultivan, y los Cujes que cada uno tiene dentro de sus casas a saver," 11 June 1783, Consolación, legajo 1350, PC, AGI.

353 . Ibid.; Book 1 (1775-1789), Protocolos Notariales (hereafter PN), Escribania de Gobierno (hereafter EG), Archivo Historico Provincial de Pinar del Río, Pinar del Río, Cuba (hereafter AHPPR). 
colonial Cuban society. Slave owners and slaves, former military personnel, militia members, Catholic priests, those with noble titles, women, and those who fell into multiple categories all participated in the area's tobacco industry. Although it is unlikely that some of these groups actually engaged in physical field labor, this in no way diminishes their role as the economic promoters, if not actual laborers, of tobacco. Together, these vastly different members of rural Cuban society helped to make the plant one of the most important agricultural enterprises in this part of the island.

Like other locations throughout the island, the importance of slaves in Filipinas' tobacco fields was not limited to their presence alone. Working alongside their free counterparts, slaves were a valuable contribution to the tobacco labor force in western Cuba, the area most closely associated with the myth of the white veguero. The 1770 tazmia reveals that slave labor was particularly important to the region's harvest. Slaves in the San Juan y Martínez district provided a significant source of workers on the 32 local tobacco farms with just under one-quarter of the vegas, particularly those along the San Sebastian River which ran just east of the villa, utilizing slave labor. In all, 19 people out of the partido's total tobacco work force of 69 were enslaved. Almost one-third of these chattel laborers were owned by one man, veguero Captain Juan de Mesa. Some slaves worked beside their owners, as was the case with don Nicolás de Otaño and don Juan de Cordova each who utilized the labor of two slaves, or Canary Island-born José Oropeza, and José Acosta who both worked with one slave. Several vegueros, however, turned to others' slaves to provide much needed workers on their vegas. Four tobacco farmers, including one who was a free black, used five slaves, hired from two separate 
slave owners, to provide the preponderance of laborers on their farms. For one veguero living in the Guane district, Manuel Ramos, hiring three slaves belonging to Captain don Matias José Duarte resulted in a spectacular harvest of 1,300 cujes, the most produced by any farm in the partido. Together, Ramos and his workers were responsible for bringing nearly 10 percent of the partido's entire crop to the royal tobacco monopoly in $1770 . .^{354}$

For these slaves and others, their day began promptly at 4 in the morning with the tolling of the work bell. Rising to fetch firewood, water and feed for the farm's animals, slaves in the Vuelta Abajo would head into the tobacco fields by daybreak. Their morning duties, which varied depending on the time of year, could include preparing the soil for the seed bed, planting, removing additional shoots from the base of the plant (hijos or "suckers"), picking off worms and other pests from the delicate leaves, harvesting the plants, and carrying them to the tobacco barns. From 10 to $11 \mathrm{a} . \mathrm{m}$. the slave would stop for lunch and a brief rest, continuing again at 11 and working until dark. At the end of the day, the slave would return to their huts and eat their last meal of the day, turning in for the night between 10p.m. and midnight. ${ }^{355}$

354 . Hidalgo Gato, “Tazmia...Partido de N. ...," 10 April 1770, San Juan y Martínez, legajo 1094, PC, AGI; Hidalgo Gato, "Tazmia...Partido de San Juan y Martines...Partido del Sur," 22 June 1770, San Juan y Martínez, legajo 1094, PC, AGI; unsigned, "Noticia de los Vecinos que comprehende el Partido de Sn Juan y Martines, y como Capn de el, doy al Sr Govor y Capn Gral con arreglo a su orden de 31 de Marzo de 1786," not dated, no place location given, legajo 1704, AGI, photocopy found in AGI, AHN, Cuba, Poblacion, 1766-1851, volume 119, LM, SC, GL, FIU. Three of the hired slaves belonged to Captain don Juan de Mesa, and the tobacco farmers who hired them were Manuel Ramos, Antonio Rubi, free black Diego de Mesa, and Domingo Gonzalez.

355. The description of a slave's average workday on the Vuelta Abajo's vegas is taken from Rodríguez-Ferrer, El tabaco habano, 95-97 quoted in Marrero, Azúcar, ilustración y concencia (1763-1868) (III), vol. 11 of Cuba: economía y sociedad, 63. 
Filipinas' slaves not only grew tobacco for their owners or those who hired their services, they also produced tobacco for themselves in plots of land known as conucos. ${ }^{356}$ Near San Juan y Martínez in 1770, six slaves named Miguel and José Antonio de Otaño, José Antonio de Oropeza, José de Mesa, and Ignacio and Francisco Cordova were listed separately from their veguero owners. Using the hours between dusk and late night when the slaves were free after a long day in their owner's tobacco fields, these slaves working on four separate conucos grew a combined total of 430 cujes of tobacco, or just over 3.5 percent of all tobacco produced in that district. While the Otaños and Cordovas harvested a larger amount of tobacco, 200 and 150 cujes each respectively, Oropeza and Mesa grew the smallest amount of tobacco of any veguero in the district by far, each turning in just 40 cujes of tobacco. ${ }^{357}$ Yet, they were not the only slaves in Filipinas to grow tobacco on their own account. Along the Cuyaguateje River in 1771, a slave named Pedro owned by

356 . José E. Perdomo, Léxico tabacalero cubano, reprint, 1940 (Miami: Ediciones Universal, 1998), 184. For more on slave conucos throughout the Americas, see Klein, Slavery in the Americas, 99; Stuart B. Schwartz, Slaves, Peasants, and Rebels: Reconsidering Brazilian Slavery (Urbana and Chicago: University of Illinois Press, 1992), 45-48; B.J. Barickman, "A Bit of Land, Which They Call Roca: Slave Provision Grounds in the Bahian Reconcavo, 1780-1860," Hispanic American Historical Review 74, no. 4 (November 1994): 649-87; Woodville K. Marshall, "Provision-Ground and Plantation Labour in Four Windward Islands: Competition for Resources During Slavery," Slavery Abolition 12, no. 1 (May 1991): 48-67. Klein notes that Cuban slaves were allowed to work their conucos on Sundays and holy days. The income from these garden plots were exempt from tithe payments, "an extremely unusual priviledge in colonial society, where the diezmos, or tithes, were the most universal form of production and property taxes."

357. Hidalgo Gato, "Tazmia...Partido de San Juan y Martínez..., Partido del Sur," 22 June 1770, San Juan y Martínez, legajo 1094, PC, AGI. The description of a slave's average workday on the Vuelta Abajo's vegas is taken from Rodríguez-Ferrer, El tabaco habano, 95-97 quoted in Marrero, Azúcar, ilustración y concencia (1763-1868) (III), vol. 11 of Cuba: economía y sociedad, 63. 
veguero Juan Antonio Ledesma grew 100 cujes of tobacco. Although he was responsible for just slightly more than 1 percent of the tobacco produced in this area that year, Pedro cultivated as much or more tobacco than seven other vegueros, all of whom were free. ${ }^{358}$ Slaves continued to grow their own tobacco in Filipinas into the 1780s. Eight slaves owned by three tobacco growers near Filipina in 1780 produced a total 792 cujes of tobacco. When compared to the harvest from the area's most prolific vegas which produced in excess of 1,000 cujes, this was only a small portion of tobacco produced in the partido, however, the combined product of these slave conucos was greater than that separately harvested by 26 of the 49 individual free vegueros listed on the 1780 tazmia. 359 The presence of people of color in the area's tobacco industry remained strong even into the late nineteenth century. According to data from 1899, people of color comprised 17 percent of all landholders in Pinar del Río, and held 11 percent of the area's land. Not only did over 75 percent of land rented by people of color in Pinar del Río were tobacco farms, but "most...seem to have come from that [tobacco] background." 360

For some of the region's slaves, like caravalis José Estrella and José Lipe, and Cuban-born Domingo de la Cruz, Filipinas' tobacco fields offered a path to freedom. Several factors point to tobacco as the source of the funds each of these men used to purchase their liberty. First, de la Cruz and Lipe were sold by the island's superintendent

358 . del Castillo, "Relasion de la Vegas...Río de Cuiaguatexe..." 30 June 1771, Cuiaguatexe, legajo 1096, PC, AGI.

359 . Lloret, "Tasmia...algunos Partidos de la Buelta de abajo...", 24 April 1780, Filipina, expediente 156, folio 228v, legajo 1261, PC, AGI.

360 . Scott, Slave Emancipation in Cuba, 263. 
of tobacco, Nicolás Rapun, and the Real Hacienda, respectively, demonstrating the slaves most likely had experience in working with tobacco or were expected to be used for that purpose. ${ }^{361}$ Secondly, all three new owners were known vegueros who were active in the years that preceded their granting freedom to these slaves. ${ }^{362}$ Yet, these were not the only slaves for whom their involvement with tobacco led to their freedom. When Antonio Bentura was sold by his former owner to a new one in April of 1775, he passed from one of Pinar del Río's most productive vegueros to an even more prolific one in San Juan y Martínez. Before the month was out, Bentura's new owner had filed manumission papers with the local notary. In less than six months, the 40-year-old Mina slave had

361 . Sargent Nicolás de Iglesias to José Lipe, Letter of Freedom, 23 October 1786, San Juan y Martínez, expediente 361, Book 1 (1775-1789), EG, PN, AHPPR; Francisco Alvarez to José Estrella, Letter of Freedom, 3 July 1783, San Juan y Martínez, expediente 205, Book 1 (1775-1789), EG, PN, AHPPR; Juan Francisco Madera to Domingo de la Cruz, Letter of Freedom, 17 December 1793, Pinar del Río, expediente 23, Book 2, EG, PN, AHPPR. The Real Hacienda had a history of selling slaves to vegueros as early as 1764 . "Nota de las cavesas de negros...," 21 March 1764, legajo 1212, SD, AGI. Chapter 3 details the sale of slaves to tobacco farmers from the 1760 s through the 1800 s.

362 . de Paula Mari, "Tasmia...Partido de San Rozendo de Pinal del Rio...," 2 June 1770, Pinar del Río, legajo 1094, PC, AGI; Hidalgo Gato, "Tasmia...Partido de San Juan y Martines...Partido del Sur...," 22 June 1770, San Juan y Martínez, legajo 1094, PC, AGI; Hidalgo Gato, "Tasmia...Partido de San Juan...," 27 March 1771, San Juan y Martínez, legajo 1096, PC, AGI; Lloret, "Tazmia...Partido de San Juan y Martines...," 1 June 1779, San Juan y Martínez, legajo 1261, PC, AGI; Romero, "Tazmia...algunos Partidos de la Buelta de abajo...," 20 June 1781, Consolación del Sur, legajo 1317, PC, AGI; de Mier, "Tazmia...Partidos de la Buelta de Abajo...," 15 June 1782, Filipina, legajo 1317, PC, AGI; de Mier, "Tazmia...Partidos de la Buelta de abajo...," 11 June 1783, Filipina, legajo 1350, PC, AGI. Nicolás Iglesias was particularly active during this time, producing tobacco for at least six out of thirteen years over a period from 1770 to 1783 . Another example of a slaves that probably earned the funds to purchase their liberty through work in the tobacco fields was María Loreto, discussed in greater detail later in this chapter. 
accumulated the 150 pesos needed to receive his freedom and on October 17, he became

a free man. ${ }^{363}$ Several factors lead to the likelihood that Bentura earned the money to buy his freedom by working in the tobacco fields. Both his previous and current owners were known vegueros of long-standing who had utilized slave labor, either their own or hired from others. ${ }^{364}$ By the mid-1770s, male slaves outnumbered their female counterparts by a ratio of over 2 to 1 . This gender disparity in Filipinas continued into the nineteenth century when the ratio was 43 female slaves to every 100 male slaves in 1846, and 47 to 100 males in 1862 . This mirrored a historical trend that was repeated elsewhere in the Americas where male slaves worked in agricultural production at higher numbers than did females, and were also less likely to be manumitted. ${ }^{365}$ Tobacco predominated Pinar

363 . Domingo Gonzales, declaratorio, 24 April 1775, San Juan y Martínez, expediente 3, Book 1 (1775-1789), PN, EG, AHPPR; Francisco de Paula Mari, "Tasmia de los Tabacos del Partido de Sn Rozendo de Pinal del Rio en la respectiva cosecha del año de 1770," 2 June 1770, Pinal del Rio, legajo 1094, PC, AGI; Francisco de Paula, "Tasmia de los Tabacos de la cosecha de 1771, 29 May 1771, Pinal de Rio, legajo 1096, PC, AGI; Domingo Gonzalez to Antonio Bentura, letter of freedom, 17 October 1775, San Juan y Martínez, expediente 27, Book 1 (1775-1789), PN, EG, AHPPR. Bentura's owners, Agustin Murquia and Domingo Gonzalez, are discussed in greater detail later in the chapter.

364 . Hidalgo Gato, "Tazmia...Partido de N.," 10 April 1770, San Juan y Martínez, PC 1094, AGI; Hidalgo Gato, "Tasmia de los Tabacos del Partido de Sn Juan respectibe a la cosecha de 1771," 27 March 1771, San Juan y Martínez, PC 1096, AGI; Lloret, "Tasmia...Partido del Sn Juan y Martines," Lloret, 1 June 1779, legajo 1261, PC, AGI.

365 . Kiple, Blacks in Colonial Cuba, appendix. In 1849, males comprised 62.1 percent of Cuba's slave population. Marrero, Azúcar, ilustración y conciencia (17631868) (I), vol. 9 of Cuba: economia y sociedad, 186. For the historiography of slave labor, manumissions, and the role of gender, see Marrero, Azúcar, ilustración y conciencia (1763-1868) (I), vol. 9 of Cuba: economía y sociedad, 178-210; Knight, Slave Society in Cuba, 78-79; Mary Karasch, "Slave Women on the Brazilian Frontier in the Nineteenth Century," in More Than Chattel: Black Women and Slavery in the Americas, edited by 
del Río's agriculture even as late as the mid-nineteenth century, making it likely that most male slaves including Bentura labored in the region's vegas. ${ }^{366}$ The ability of slaves in the Americas to engage in agricultural pursuits for their own benefit was not uncommon, as previously discussed in this chapter. Filipinas clearly demonstrate that some slaves were given the opportunity to grow tobacco on their own account, apart from the labor they provided to their owners, making it probable that Bentura earned the money to purchase his freedom from his work in tobacco. Unlike other agricultural endeavors in which the products grown were for one's own consumption, the slave growing tobacco had a guaranteed market for their product in the form of the royal monopoly, and as a result the certainty of a financial reward for their work.

Yet, isleños, slaves, and their owners were not the only ones for whom tobacco provided a source of income. Recent studies have emphasized the close association between the military, particularly retirees, and farming in the island's countryside. ${ }^{367}$ For those in Filipinas, this meant that they turned to the area's most popular crop, tobacco.

Darlene Clark Hine, Jr. John McCluskey, Barry David Gaspar (Bloomington and Indianapolis: Indiana University Press, 1996), 87-88; Schwartz, Slaves, Peasants, and Rebels, 73-74; Frederick P. Bowser, "The Free Person of Color in Mexico City and Lima: Manumission and Opportunity, 1580-1650," in Race and Slavery in the Western Hemisphere: Quantative Studies, edited by Stanley L. Engerman, Eugene D. Genovese (Princeton: Princeton University Press, 1975), 331-68.

366 . de Lamadrez, "Resumen general...Nueva Filipina...," 1 July 1787, Pinal del Río, legajo 1407, PC, AGI; de Villera, "Resumen general...Jurisdiccion de la Nueba Poblacion de Filipina,...," 1 April 1788, Pinal del Río, legajo 1707, PC, AGI; Gonzalez, "Plan demostrativo...," 31 May 1817, Real Factoría de Tabacos, La Habana, legajo 2019, SD, AGI; Dollero, La provincia de Pinar del Río, 318-19; Pérez, Winds of Change, 95.

367 . Johnson, Social Transformation, 39-70. 
One such example was don Nicolás Ramos, a sergeant in the Guane del Sur Company, diputudo (tobacco farmer representative) and a tobacco farmer for at least two decades. Unlike other military members currently serving in the area who were predominately from Havana, Ramos was born in Filipina around 1728. In 1770, the 42-year-old Ramos owned one vega in the area of Guane del Sur, near the Portales and Cuyaguateje Rivers. The tobacco accounting sheet for that year's harvest noted that Ramos's farm was worked by a total of four people and yielded 1,000 cujes of tobacco, making him tied for the second-largest tobacco producer that year. While tobacco production on his vega dropped to just 600 cujes the following year, he remained the second-largest grower of tobacco in the area. By 1781, four people continued to work the now-53-year-old's tobacco farm, but they cultivated only 150 cujes of tobacco according to that year's tazmia. 368

Another veguero with military ties was Mateo Morgado, originally from Sancti Spiritus in the eastern-central part of the island. Some time during the early 1770 s,

368 . Nicolás Ramos, Nicolás Hernandez, Antonio Sánches, et. al. to Teniente Gobernador, undated, circa 1780, legajo 1261, PC, AGI; Luis Dias Pimienta, "Noticia de los Vezinos que comprehende el partido de Guane del Sur y como capitan doy al Senor Gobernador y Capitan General con arreglo a su orden de tienta y uno de Marzo de mil setecientos ochenta y seis," 20 April 1786, Partido de Guane del Sur, photocopy in AGI, AHN, Cuba, Poblacion, 1766-1851, volume 119, LM, SC, GL, FIU; Matias Joseph Duarte, "Tasmia de los Tabacos del Partido de Sn Ildefonso de Guanes respectiva a la cosecha de 1770," 6 June 1770, San Ildefonso de Guanes, legajo 1094, PC, AGI; Miguel Castillo, "Relasion de las Vegas que se han cultivado tavacos, en el presente año en el rio de cuiagatexe con individualidad de los sujetos, cujes y manojos que pueden produsir," 30 May 1771, Cuiguatexe, legajo 1096, PC, AGI; de Mier, "Tasmia...algunos Partidos de la Buelta de Abajo...," 20 June 1781, Filipina, legajo 1317, PC, AGI; José Ramos to Teniente Bonafacio Guzman, venta de asenso, 22 July 1775, Filipinas, expediente 15 , folio 13, Book 1 (1775-1789), PN, EG, AHPPR. 
Sergeant Morgado purchased from José Ferrara a tobacco farm located along the banks of the Cuyaguateje River and bordering the royal road (camino real). In 1770, a vega owned by the 44-year-old Morgado and worked by three people, perhaps including the sergeant himself, produced 650 cujes of tobacco, nearly 150 sticks more than the area's average, while the following year's harvest was 330 cujes, over double the previous year's. ${ }^{369} \mathrm{By}$ early 1777 , he had been promoted to lieutenant junior grade and had purchased a home in the villa of Filipinas as was befitting his new rank. In the early 1780 s, he began to sell his current vega holdings, selling a tobacco farm located along the Cuyaguateje River, perhaps the same one he had owned for a decade, for 250 pesos. A slightly-larger property, a vega described as capable of being worked by four men, was sold on November 27, 1781 to Rafael Ilobera for the same price. ${ }^{370}$ Morgado, nevertheless, remained actively involved in the area's tobacco industry. As late as August 1793, the 67-year-old purchased a farm from Captain (reformed militia) Tomás de Sierra for 150

369 . Duarte, "Tazmia...Partido de $S^{n}$ Ildefonso de Guane...," 6 June 1770, San Ildefonso de Guane, legajo 1094, PC, AGI; del Castillo, "Relasion de la Vegas...Río de Cuiaguatexe," 30 June 1771, Cuiaguatexe, PC 1096, AGI; Mateo Morgao to Antonio Sanches, venta de asenso de vega 19 February 1780 , Filipina, folio $228 \mathrm{v}$, expediente 156 , Book 1 (1775-1789), EG, PN, AHPPR; Dias Pimienta, "Noticia de los Vezinos...partido de Guane del Sur...," 20 April 1786, Partido de Guane del Sur, photocopy in AGI, AHN, Cuba, Poblacion, 1766-1851, volume 119, LM, SC, GL, FIU.

370 . Ana Sánchez to Mateo Morgado, Sale of House (venta de casa), 2 January 1777, Filipina, expediente 73, Book 1 (1775-1789), PN, EG, AHPPR; Morgao to Sanches, venta de asenso de vega 19 February 1780, Filipina, folio 228v, expediente 156 , Book 1 (1775-1789), EG, PN, AHPPR; Mateo Morgao to Rafael Ilobera, venta de vega, 27 November 1781, Filipina, f 272v, expediente 185, Book 2, EG, PN, AHPPR. Owned by Ana Sánchez for three years before she sold it, the adobe-like material and palm-thatch roof home was located next to houses owned by Juan de Alba and Cristóbal Lucero, and was purchased by Moragado for 100 pesos. 
pesos. This vega was located along the Paso Real and bordered farms owned by Luis Lantigea and Nicolás Ramos. ${ }^{371}$ Mateo Morgado's actions demonstrates the fluidity within Filipina's colonial tobacco-growing industry. Area vegueros, like those throughout the island, did not buy a farm and hold onto it for decades. Instead, vegas frequently changed hands as tobacco farmers searched different areas for the best tobacco land.

Members of the military were not the only residents of Cuba with ties to Filipinas's tobacco industry. Currently absent from the existing historiography of Cuba's vegueros, women participated in Filipinas's tobacco cultivation, either as vega owners in their own right or with their husbands. Even before the period covered by this study, 1763 to 1817 , women actively participated in promoting tobacco in Filipinas. In 1760, no less than 4 women were included among 49 individuals responsible for delivering tobacco to the royal monopoly from the Guane district. Combined, these women presented 116 tercios (approximately 170 pounds of tobacco), or about 8 percent, of the area's crop which was now held in Havana's Real Fuerza fort. ${ }^{372}$

This was far from the only time that women were active participants in Filipinas's tobacco industry, as evidenced from the numerous tazmias from this region. Although far from being the largest producers in their respective districts, vega owner Cathalma

371. Tomás de Sierra to Mateo Morgado, venta de vega, 20 August 1793, Filipinas, folio 61, expediente 83, Book 2, EG, PN, AHPPR; Dias Pimienta, "Noticia de los Vezinos...partido de Guane del Sur...," 20 April 1786, Partido de Guane del Sur, photocopy in AGI, AHN, Cuba, Poblacion, 1766-1851, volume 119, LM, SC, GL, FIU.

372. Tio, "Noticia...Partido de Guanes...," 13 May 1760, Havana, legajo 2016, SD, AGI; Deans-Smith, "The Money Plant," 384. 
Rodríguez yielded 123 cujes of tobacco, making her responsible for approximately 7 percent of the 1770 crop, while in the partido of Pinar del Río, Ursula Peréz delivered 100 sticks of tobacco in 1770, and widow Ursula Hernández produced 200 cujes of tobacco the following year. ${ }^{373}$ Other women such as Catarina de la Torre, Josefa Figueroa, Thomasa Lorenzo, and Juana Ramos Montero also grew tobacco. Only one, the 42-year-old Figueroa who was originally from Havana, was listed on a single tazmia, responsible for 140 sticks of tobacco, indicating that she was not a long-term investor in the area's tobacco industry. The remaining women, however, continued to be active over a period of time. Pinar del Río area veguera Catarina de la Torre owned a tobacco farm that produced 280 cujes in 1780 and 325 cujes in 1783, whereas Lorenzo held a vega in the Guane district that produced 250 sticks of tobacco during the 1781 harvest and 250 cujes the following year. Two of her slaves, who most likely supplied the majority of labor on her vega in 1782, also grew tobacco on their own account, cultivating 50 cujes. ${ }^{374}$ Whereas the women described above had smaller tobacco farms, Ramos

373 . de Sierra, "Tazmia....partido de Guane...," 1 May 1770, Partido de Guane, legajo 1094, PC, AGI; de Paula Mari, 2 "Tasmia...Partido de Sn Rozendo de Pinal del Rio...," June 1770, Pinar del Río, legajo 1094, PC, AGI; de Paula Mari, "Tasmia...Partido de Pinal del Rio...," 29 May 1771, Pinar del Río, legajo 1096, PC, AGI.

374 . Romero, "Tazmia...algunos Partidos de la Buelta de Abajo...," 22 April 1780, Consolacion, legajo 1261, PC, AGI; de Mier, "Tasmia...Algunos Partidos de la Buelta de Abajo...," 20 June 1781, Filipina, legajo 1317, PC, AGI; de Mier, "Tazmia...Partidos de la Buelta de Abajo...," 15 June 1782, Filipina, legajo 1317, PC, AGI; Romero, "Tazmia...algunos Partidos de la Buelta de abajo...," 11 June 1783, Consolacion, legajo 1350, PC, AGI; "Noticia de los Vecinos que Comprehende el Partdo de consolacion del Norte, y como Capn de el doy al Sr Govor y Capn Gral con arreglo a su Orden de treinta y uno de marzo de mil setecientos ochenta y seis," 21 April 1786, Consolación del Norte, photocopy in AGI, AHN, Cuba, Poblacion 1766-1851, vol. 119, LM, SC, GL, FIU. 
Montero's vega contained 30,000 tobacco plants, according to her last will and testament from March of 1793.375

Other women such as Catarina Morejon and María Martínez participated in the tobacco industry with their respective husbands, Manuel Benitez and Antonio Perez Guerra. In 1793, Morejon and Benitez, residents of San Juan y Martínez, sold a 1caballeria (approximately 33.3 acre) tobacco farm located in the paraje of Garcia to Juan Cortes for 912 pesos, while the following year, Martínez and Perez Guerra sold a vega located along the San Juan River in San Juan y Martínez to Antonio Garcia for 300 pesos. ${ }^{376}$ Colonial Cuban women's lives were dictated by the tenets of honor, loyalty, and virtue framed within a context of power and race. Yet, the personal agency demonstrated by all of these women to engage in economic transactions on their own was not uncommon for Latin American society, particularly for Cuba during this period. 377

375 . Juana Ramos Montero, testament, 5 March 1793, folio 20v, expediente 56, Book 2, PN, EG, AHPPR. Born in Filipinas, her parents were Fernando Ramos and Francisca Montero. In addition to the tobacco farm, her property included three slaves, some money, a house and furnishings. Her ties to the area's tobacco industry also included marriage to a local veguero, Nicolás Hernández. See de Mier, “Tasmia...Algunos Partidos de la Buelta de Abajo...," 20 June 1781, Filipina, legajo 1317, PC, AGI; de Mier, "Tazmia...Partidos de la Buelta de Abajo...," 15 June 1782, Filipina, legajo 1317, PC, AGI.

376. Manuel Benitez and Catarina Morejon to Juan Cortes, venta condicional de asiento de vega, 16 April 1793, Filipinas, folio 29v, expediente 60, Book 2, PN, EG, AHPPR; Antonio Perez Guerra and Maria Martinez to Antonio Garcia, venta de asiento de vega, 28 Aug 1794, Filipina, folio 65, expediente 161, Book 2, PN, EG, AHPPR.

377 . Stern, The Secret History of Gender; Twinam, Public Lives, Private Secrets; Socolow, The Women of Colonial Latin America; Caulfield, "The History of Gender"; Martínez-Fernández, "The "Male City' of Havana"; Johnson, " Señoras en Sus Clases no Ordinarias." 
Tobacco was an important source of income for more than just the men and women who cultivated it. For Miguel de Peñalver, the man who offered land and materials for the new town of Filipinas, tobacco represented a significant economic component. A sampling of tobacco land sales from Filipinas from the last part of the eighteenth century demonstrates the financial return that tobacco indirectly represented to Peñalver. As the owner of the San Sueña hacienda, Peñalver was entitled to receive payment from those who held usufruct rights to his land. Land sale records between the summer of 1775 and fall of 1776 note that Peñalver received no less than 50 pesos annually from new vega owners Lieutenant Bonafacio Guzman, Andres Garcia, Juan Baptista Goyevins, Carlos Fontanil, Felix Lopez, and Isabel Valez, who purchased their tobacco farms located along the Cuyaguateje River, land that was part of Peñalver's ranch. $^{378}$

\section{The Interconnected Nature of Tobacco Cultivation}

Tobacco ultimately provided the very fiber that shaped and maintained the rural society of Filipinas, tying those from very different social, ethnic, racial, and economic backgrounds to one another. Through the cultivation and promotion of tobacco, free and

378 . Joseph Ramos to Lieutenant Bonafacio Guzman, venta de asenso, 22 July 1775, expediente 15, folio 13, Book 1 (1775-1789), PN, EG, AHPPR; Juan de Almendares to Andres Garcia, venta censo vega, 3 December 1775, Filipinas, 3 folio 39, expediente 34, Book 1 (1775-1789), PN, EG, AHPPR; Marcos Rodriquez to Juan Bautista Goyevins and Carlos Fontanil, venta asiento de vega, 12 Sep 1776, folio 70, expediente 54, Book 1 (1775-1789), PN, EG, AHPPR; Francisco Moreno to Felix Lopez, venta asiento de vega, 10 Oct 1776, Filipinas, folio 93, expediente 67, Book 1 (17751789), PN, EG, AHPPR; Francisco Padrin to Isabel Valez, venta asiento de vega, 18 April 1776, Filipinas, folio 107, expediente 79, Book 1 (1775-1789), PN, EG, AHPPR. 
slave, white and black, rich and poor vegueros competed with one another to bring in the largest harvest and profit for their hard work, demonstrating the interconnectiveness of this region's agricultural producers and community at large. In a isolated territory like Filipinas, few other economic pursuits could have led such a diverse group of men San Juan y Martínez residents isleño Domingo González, Lieutenant Manuel del Castillo, Father José Cipriano de Ignocencio, and free black Diego de Mesa to compete economically. ${ }^{379}$

Situated 51 leagues west of Havana, San Juan y Martínez was approximately halfway between the most distant partido of the new jurisdiction, Mantua, and Consolación del Sur and Consolación del Norte, both just 40 leagues from the capital. The district was located in the shadow of the Sierra de Guane and Alturas de Pizarras del Sur mountains. Fed by the San Juan y Martínez, San Sebastian, and Seco Rivers, these fertile lands produced what one traveler touted as "the best tobacco in the world." 380 The town of San Juan y Martínez was one of the region's smallest, virtually nonexistent except for one lone house and a church as late as 1789 , whereas the largest villa in the jurisdiction, nearby Pinar del Río, boasted 20 houses. The surrounding countryside, however, supported a vibrant agricultural community of between 426 and 462 souls who lived living in the countryside on the many tobacco vegas, approximately a dozen hatos, and

379 . de Lamadriz, "Resumen general...Jurisdicíon de la Nueva Filipina...," 1 July 1787, Pinar del Río, legajo 1407, PC, AGI; Lloret, "Resumen general...Jurisdicíon de la Nueba Poblacion de Filipina...," 1 April 1788, Pinar del Río, legajo 1407, PC, AGI; de Villoro, "Resumen general...Jurisdicíon de la Nueba Poblacion de Filipina...," 1 April 1789, Pinar del Río, legajo 1407, PC, AGI.

380 . Abbot, Letters Written in the Interior, 200. 
several corrales. As was the trend elsewhere in Filipinas, the number of vegas in San Juan y Martínez dropped from the 1770 s through the end of the 1780s, falling from 32 in 1770 to a low of 22 in 1779 , but managing to recover to around 50 by the end of the decade. ${ }^{381}$ San Juan y Martínez's tobacco vega remained an important nucleus of life for its rural residents into the mid-nineteenth century with 97.4 percent of the partido's inhabitants in 1846 residing on one of the area's 560 tobacco farms. ${ }^{382}$

Domingo González, isleño, veguero, slave owner, employer of hired slave labor, and militia member, provides perhaps the most glaring example of the diversity found among Filipinas' tobacco farmers. Born around 1731 or 1732 in the Canary Islands, González emigrated to Cuba by the mid-1750s and spent at least two decades or more making a livelihood from growing tobacco in the San Juan y Martínez district. At the time of his marriage to María Asuncíon de los Reyes in 1757 when he was in his midtwenties, González had accumulated 426 pesos in silver in capital. Eventually, however, he would come to own at least five slaves, and a tobacco farm in the partido of San Juan y Martínez valued at 3,000 pesos. ${ }^{383}$

381 . de Lamadriz, "Resumen general...Jurisdicíon de la Nueva Filipina...," 1 July 1787, Pinar del Río, legajo 1407, PC, AGI; Lloret, "Resumen general...Jurisdicíon de la Nueba Poblacion de Filipina...," 1 April 1788, Pinar del Río, legajo 1407, PC, AGI; de Villoro, "Resumen general...Jurisdicíon de la Nueba Poblacion de Filipina...," 1 April 1789, Pinar del Río, legajo 1407, PC, AGI; Hidalgo Gato, "Tazmia...Partido de N....," 10 April 1770, San Juan y Martínez, legajo 1094, PC, AGI; Lloret, "Tasmia...Partido de Sn Juan y Martines...," 1 June 1779, San Juan y Martínez, legajo 1261, PC, AGI.

382. Marrero, Azúcar, ilustracion y conciencia (1763-1868) (III), vol. 11 of Cuba: economía y sociedad, 61.

383 . For biographical information, see unsigned, "Noticia de los Vecinos que comprehende el Partido de Sn Juan y Martines, y como Capn de el, doy al Sr Govor y 
For the González family, tobacco cultivation was a truly a family affair as even his wife, María Asuncíon de los Reyes, was a vega owner. Born in the San Juan y Martínez district, de los Reyes was the legitimate daughter of Francisco de los Reyes and Teresa de Mena, both naturals of the city of Havana. On January 30,1777 , the gravely ill mother of five living minor children dictated her will before a local notary. She requested burial in the habit of San Domingo in the iglesia auxiliar of San Juan Bautista to be accompanied by three masses of the soul. While de los Reyes brought no capital to the union at the

Capn Gral con arreglo a su orden de 31 de Marzo de 1786," not dated, no place location given, legajo 1704, AGI, photocopy found in AGI, AHN, Cuba, Poblacion, 1766-1851, volume 119, LM, SC, GL, FIU; Vicente Blanco, "Pie de lista de la compañia suelta del Partido de San Juan y Martines, edad, nombres, y oficios de todos," 31 July 1779, San Juan, legajo 1269, PC, AGI; María de la Asumpcíon de los Reyes, testamento, 19 October 1785, folio 484, expediente 309, Book 1 (1775-1789), PN, EG, AHPPR, Pinar del Río, Cuba. For González's activities as a tobacco farmer including use of hired slave labor, see Hidalgo Gato, "Tazmia...Partido del N....," 10 April 1770, San Juan y Martínez, legajo 1094, PC, AGI; Hidalgo Gato, "Tasmia...Partido de Sn Juan y Martines...Partido del Sur," 22 June 1770, San Juan y Martínez, legajo 1094, PC, AGI ; “Tasmia...San Juan...," Hidalgo Gato, 27 March 1771, San Juan y Martínez, legajo 1096, PC, AGI; "Tasmia...Partido de Sn Juan y Martínes...," 10 March 1772, legajo 1180, PC, AGI; Lloret, "Tasmia..Partido de Sn Juan y Martines...," 1 June 1779, San Juan y Martínez, legajo 1261, PC, AGI; Lloret, "Tasmia...algunos Partidos de la Buelta de abajo...," 24 April 1780, Filipina, legajo 1261, PC, AGI; de Mier, "Tasmia...Algunos Partidos de la Buelta de Abajo...," 20 June 1781, Filipina, legajo 1317, PC, AGI; de Mier, "Tazmia...los Partidos de la Buelta de Abajo...," 15 June 1782, legajo 1317, PC, AGI; de Mier, "Tazmia...algunos Partidos de la Buelta de abajo...," 11 June 1783, legajo 1350, PC, AGI. For transactions regarding the purchase, sale, and freeing of González's slaves, see José Ignocencio to Domingo Gonzalez, Sale of Slave (Mariano), 29 May 1775, San Juan y Martínez, expediente 7, Book 1 (1775-1789), PN, EG, AHPPR; Juan Ignocencio to Domingo Gonzalez, Sale of Slave (María Francisca), expediente 8, Book 1 (1775-1789), PN, EG, AHPPR; Domingo Gonzalez to Antonio Bentura, Letter of Freedom, 17 October 1775, Filipina, folio 31, expediente 27, Book 1 (1775-1789), PN, EG, AHPPR; Nicolás Hidalgo Gato to Domingo Gonzalez, Sale of Slave (María del Rosario), Filipina, 7 May 1777, expediente 82, Book 1 (1775-1789), PN, EG, AHPPR; Domingo Gonzalez to Vicente Pedroso, Letter of Freedom, 17 October 1800, San Juan y Martínez, expediente 61, Book 2, PN, EG, AHPPR. 
time of her marriage to Domingo González twenty years before, her possessions now included two unbaptized slaves named María del Rosario and José Narcisco, three mares, two riding horses, a two-year old colt, and two vegas, one that had a tobacco barn that was in poor condition, and the other with a house, tobacco barn, and separate kitchen building. 384

Luckily for her family, she recovered, but by October 19, 1785, had again become sick enough that she felt it necessary to update her will before a local notary. Two more sons, Pedro and Domingo, had been born and in the years that transpired, her financial holdings had increased significantly, perhaps as a result of inheritance left by her nowdeceased parents. This time she requested burial in the chapel of Nuestra Señora de la Candalaria in the Church of San Juan. She still owned two rural properties, a vega which contained a house and two tobacco barns of varying condition. The other, described as a three caballeria (approximately 100 acres) sitio (farm) located in the jurisdiction of Santiago and bordering land belonging to a marquis, was purchased at public auction for 2,840 pesos and contained two houses, a kitchen, and a tobacco barn. Additionally, de

384 . María Asuncíon de los Reyes, testament, 30 January 1777, San Juan y Martínez, folio 97, expediente 71, Book 1 (1775-1789), PN, EG, AHPPR. The children were José, Esteban José, María de las Nieves, Juan, and Eduardo Francisco. This is not the same slave, also named María del Rosario, that her husband purchased from Nicolás Hidalgo Gato in May. See Nicolás Hidalgo Gato to Domingo Gonzalez, Sale of Slave (María del Rosario), Filipina, 7 May 1777, expediente 82, Book 1 (1775-1789), PN, EG, AHPPR. 
los Reyes owned a house in the town of San Juan, two male slaves named José and Carlos, and seven yokes of oxen. 385

Not even the area's only priest, Father José Cipriano de Ignocencio, failed to participate in the local tobacco industry. A resident of San Juan y Martínez by 1775 or earlier, by mid-June of 1782, he had purchased a vega in the partido of San Juan y Martínez, where two unidentified people labored in his fields. In less than a year, however, he was no longer growing tobacco in the district. As demonstrated earlier in this chapter, the composition of those owning tobacco farms in colonial Cuba was extremely fluid, with individuals buying and selling vegas from one year to the next. Father Cipriano was no exception. In the three years that preceded, the priest was not listed among the vega owners in the district of San Juan y Martínez or surrounding areas, making it likely that he purchased the farm between June 20, 1781 and April 22, 1862, between the time when the tazmias were compiled. ${ }^{386}$

385 . María de la Asumpsion de los Reyes, testament, 19 Oct 1785, folio 484, expediente 309, Book 1 (1775-1789), PN, EG, AHPPR. De los Reyes specified that the animals should be left to the local capitán del partido, Nicolás Hidalgo Gato.

386 . de Lamadriz, "Resumen general...Jurisdicíon de la Nueva Filipina...," 1 July 1787, Pinar del Río, legajo 1407, PC, AGI; José Ignocencio to Domingo Gonzalez, venta de esclavo, 29 May 1775, San Juan y Martínez, expediente 7, Book 1 (1776-1789), PN, EG, AHPPR; de Mier, "Tazmia...Partidos de la Buelta de Abajo...," 15 June 1782, Filipina, PC 1317, AGI; Romero, "Tazmia... algunos Partidos de la Buelta de abajo...," 22 April 1782, Consolación del Sur, legajo 1261, PC, AGI; Lloret, "Tasmia...Partidos de la Buelta de abajo," 24 April 1780, Filipina, expediente 156, folio 228v, legajo 1261, PC, AGI; Bernardo Romero, "Tazmia correspondte a algunos Partidos de la Buelta de abajo o sotavento qe se me han hecho cargo, en que corresponde las Vegas de tavaco, los Dueños, operarios que las cultiban, y los cujes que cada uno tiene dentro de sus casas a saver," 20 June 1781, Consolación del Sur, legajo 1317, PC, AGI; Gabriel de Mier, "Tazmia correspondiente a algunos Partidos de la Buelta de Abajo o Sotavento en qe comprehende 
Although other districts in the far western part of the island had larger yields, the 12,090 cujes produced in San Juan y Martínez in 1770 was one of the partido's biggest crops of the decade. ${ }^{387}$ The majority of vegueros, 23 out of 37 named individuals, did not work alone on their tobacco land, using at least one and as many as three additional laborers. Four pairs of men were partners, each co-owning the vega they worked together, whereas five tobacco farmers relied on family members, primarily sons although one used several nephews, to supply the needed hands in the field. Slave labor was used by eight vegueros, primarily hired from fellow tobacco farmers and slave owners, while two utilized free laborers to assist them. ${ }^{388}$ Veguero and Canary Island native, Domingo González began to experiment with slave labor on his farm located near the San Sebastian River by at least 1770 . That year, he hired two slaves from fellow tobacco farmer

las vegas de Tabaco, los Duenos, operaríos que las cultiban y los cujes qe cada uno tiene dentro de sus casas a saber," 20 June 1781, Filipina, legajo 1317, PC, AGI.

387 . de Sierra, "Tazmia...Partido de Guane en la costa de el Norte," Habarro, 24 May 1770, legajo 1094, PC, AGI; "Duarte, Tasmia...Partido de Guane...Partido de Sur," San Ildefonso de Guane, 6 June 1770, legajo 1094, PC, AGI; Duarte, "Tazmia...Partido de Consolacion...," legajo 1094, PC, AGI; de Paula Mari, "Tasmia...Partido de Sn Rosendo de Pinal del Rio...," 2 June 1770, Pinar del Río, legajo 1094, PC, AGI; Hidalgo Gato, "Tazmia...Partido del N....," 10 April 1770, San Juan y Martínez, legajo 1094, PC, AGI; Hidalgo Gato, "Tasmia...Partido de Sn Juan y Martines...Partido del Sur," 22 June 1770, San Juan y Martínez, legajo 1094, PC, AGI; Hidalgo Gato, "Tasmia...San Juan...," 27 March 1771, San Juan y Martínez, legajo 1096, PC, AGI; Hidalgo Gato, "Tasmia...Partido de Sn Juan y Martínes...," 10 March 1772, legajo 1180, PC, AGI; Lloret, "Tasmia..Partido de Sn Juan y Martines...," 1 June 1779, San Juan y Martínez, legajo 1261, PC, AGI.

388 . Hidalgo Gato, “Tazmia...Partido del N....," 10 April 1770, San Juan y Martínez, legajo 1094, PC, AGI; Hidalgo Gato, "Tasmia...Partido de Sn Juan y Martines...Partido del Sur," 22 June 1770, San Juan y Martínez, legajo 1094, PC, AGI. Only the individuals vegueros listed as owners were included in this calculation. 
Captain Juan de Mesa, who supplied many of the area's hired slaves. The project proved

to be quite successful, and González was able to yield 800 cujes of tobacco, tying him

with Lieutenant Manuel del Castillo for the title of the area's largest tobacco producer.

Together, González and del Castillo, assisted by a total of four slaves, were responsible

for 13 percent of the partido's harvest. Their nearest competitor was 31-year-old Antonio

Rubi, who produced 600 sticks of tobacco with the help of two slaves hired from Captain

Nicolás Hidalgo Gato. Growing the third-highest amount of tobacco, 500 cujes, were

four vegueros, don Nicolás de Otaño, Simon de Acosta, Nicolás Iglesias, and Juan

Quintana. Only de Otaño used slave labor, while Quintana turned to two sons, and

Acosta and Iglesias co-farmed with Antonio Perez and Francisco Fletes, respectively. ${ }^{389}$

The following year, tobacco production declined, but was much more evenly

distributed amongst the 31 vegueros in the partido of San Juan y Martínez. González

was the district's largest tobacco grower in terms of the amount of tobacco produced for

389 . Hidalgo Gato, "Tazmia...Partido de Sn Juan y Martínez...Partido del Sur," 22 June 1770, San Juan y Martínez, legajo 1094, PC, AGI; Nicolás Hidalgo Gato, "Tasmia de los Tabacos del Partido de $\mathrm{S}^{\mathrm{n}}$ Juan respectibe a la cosecha de 1771," 27 March 1771, San Juan y Martínez, legajo 1096, PC, AGI; Lloret, "Tasmia...Partido del $\mathrm{S}^{\mathrm{n}}$ Juan y Martines," 1 June 1779, legajo 1261, PC, AGI; unsigned, "Noticia de los Vecinos...Partido de Sn Juan y Martines...," not dated, legajo 1704, PC, AGI, photocopy in AGI, AHN, Cuba, Poblacion, 1766-1851, volume 119, LM, SC, GL, FIU. All of the primary names and the numbers of operarios used listed on the tazmias for the north and south part of the San Juan y Martínez districts match, with the exception of one entry, while the amount produced, however, varies widely between the two documents. Taken less approximately two-and-a-half-months apart, in April 10 and June 22, 1770, and both signed by Nicolás Hidalgo Gato, it appears unlikely that the same vegas were mistakenly recorded twice without officials catching the mistake, and most likely the later document was intended as a revision of the earlier figures. The use of different geographic descriptors appears to be merely an error. The production figures utilized come from the later, revised document. 
the royal monopoly. He employed three unidentified workers, perhaps the same slaves he had hired the year before, on his vega near the San Sebastian River, and his harvest of 700 cujes represented almost 10 percent of the district's entire crop that year. The drop in overall production significantly benefited free black Diego de Mesa who went from one of seven vegueros competing for the title of fourth-largest tobacco grower in 1770 , to tied with Lieutenant Manuel del Castillo for second place as the partido's largest producer in 1771. Although the identity of the additional worker on his vega in 1771 is unknown, it is possible that de Mesa continued to use a slave hired from a local slave owner, as he had done the year before. 390

Throughout the 1770s and 1780s, Domingo González continued as one of the largest, if not the largest, tobacco producers in the San Juan y Martínez district. By 1779, González easily led the field, growing 400 cujes of tobacco for the royal monopoly, while his closest competitor, Joaquin Gutierrez yielded 350 cujes and long-time rivals Nicolás Iglesias and Antonio Rubi contributed just 200 and 50 cujes, respectively. The following year, 1780, Iglesias recovered and managed to oust González from his title of highest producer. With a remarkable 800 cujes, he not only outproduced González by 200 cujes, his San Sebastian River vega supplied more tobacco to the Real Factoria than any other tobacco farm in the district. Meanwhile, like other vegueros, Gutierrez had left the area's tobacco industry altogether, and Rubi held steady at a mere 50 cujes, giving him among

390 . Hidalgo Gato, "Tasmia...Partido de $S^{\mathrm{n}}$ Juan," 27 March 1771, San Juan y Martínez, legajo 1096, PC, AGI. Although they shared the same surname, the connection between Diego de Mesa and Captain Juan de Mesa, if any, is unknown at this time. It is possible that Diego de Mesa and the slave he hired had both been owned by the captain. 
the district's smallest crops for that year. The entrance of the local capitan del partido (constable) Vicente Blanco into the area's tobacco industry in 1781 and 1782 challenged González's reign as the leading tobacco producer in San Juan y Martínez, pushing the isleño down in the rankings to second-place in 1781 with 500 cujes tended by four people as compared to 600 cujes delivered by just three people working on Blanco's farm. The following year, 1782, Blanco and another farmer, 50-year-old Canary Islander and slave owner José Oropeza, each turned in 500 cujes of tobacco, while González held on to second place with 400 cujes. As Nicolás Iglesias experienced a declining work force which dropped from a high of three workers in the late 1770 s through 1781 , to a low of just one person in 1783 , his fortunes waxed and waned from year to year. In 1781 , he tied for sixth place (200 cujes) with four other people, dropped to eighth place along with five other vegueros who produced just 100 cujes the following year, and rebounded in 1783 when he and González each grew 300 cujes of tobacco. The dedication of these two men to the area's tobacco industry was seen in their longevity. While many of the other top producers in previous years, Joaquin Gutierrez, Antonio Rubi, and Captain Vicente Blanco, were no longer engaged in the cultivation of tobacco in San Juan y Martínez, Nicolás Iglesias and Domingo González remained as constant fixtures in the district's tobacco fields. ${ }^{391}$

391 . Lloret, "Tasmia...Partido de San Juan y Martines...," 1 June 1779, San Juan y Martínez, legajo 1261, PC, AGI; de Mier, unsigned, "Tazmia...algunos Partidos de la Buelta de abajo...," 20 June 1781, Filipina, legajo 1317, PC, AGI; de Mier, "Tazmia...Partidos de la Buelta de Abajo...," 15 June 1782, Filipina, legajo 1317, PC, AGI; de Mier, "Tazmia...algunos Partidos de la Buelta de abajo...," 11 June 1783, Filipina, legajo 1350, PC, AGI. 
Another town with strong roots in Filipinas's tobacco industry was Pinar del Río, located along the winding Guamá River about 45 leagues west of Havana in the eastern foothills of the Alturas de Pizarras del Sur. Unlike Cuba's five other historical provincial capitals, Pinar del Río was born "spontaneously" at the end of the seventeenth century. Frequent floodings from the nearby river prompted its move to a higher location in 1726 , and again in 1746, when it reached its final location. ${ }^{392}$ Like San Juan y Martínez, the town was humble, so much so that even as late as the end of the eighteenth century, Pinar del Río was described as "“a small town that consists of 20 to 25 houses and its parish church, all made from palm trees..."'393 Tobacco, the area's primary agricultural pursuit, provided an important source of income for its residents. In 1770, the district of San Rosendo de Pinar del Río boasted 68 vegas worked by 97 people, making it the largest tobacco producing partido in the area that year. ${ }^{394} \mathrm{By} 1787$, the district supported the greatest number of tobacco farms, 70, of any in the jurisdiction, surpassing second-place

392. Marrero, Azúcar, ilustración y conciencia (1763-1868) (I), vol. 9 of Cuba, economía y sociedad, 215.

393. "Memoria del reconocimiento de la parte occidental de esta Isla, ejecutado por don José María de la Torre...y don Antonio López Gómez, de orden del Sr. Conde de Mopox y Jaruco," (Memorias de la Real Sociedad Patriótica de La Habana, Segunda época, number 25, page 430) quoted in Ibid., 216.

394 . de Paula Mari, "Tasmia...Pinal del Río...," 2 June 1770, Pinar del Río, legajo 1094, PC, AGI; Hidalgo Gato, "Tasmia...San Juan y Martínez, Partido del Sur," 22 June 1770, legajo 1094, PC, AGI; Duarte, "Tasmia...Partido de...Guane...Partido de Sur," 6 June 1770, San Ildefonso de Guane, legajo 1094, PC, AGI; Duarte, "Tazmia...Partido de Consolacion...," legajo 1094, PC, AGI; de Sierra, "Tazmia...partido de Guane...en la costa de el Norte," 24 May 1770, Habarro, legajo 1094, PC, AGI. 
San Juan y Martínez by 21 . The following year, its lead grew even more to 84 vegas in all, followed by Consolación del Sur with 58, and San Juan y Martínez at $48 .{ }^{395}$

As in San Juan y Martínez, the shared pursuit of tobacco cultivation connected the residents to one another, linking such disparate people as former slaves María Loreto, slave owners and vegueros Jacinto and Anzieto Morejon, and Agustín Murquia, and free black José Antonio Ribero. The case of parda (mulatto) María Loreto was similar in some ways to vega owner and San Juan y Martínez resident María Asuncíon de los Reyes, discussed in detail above, in that she was married to a veguero and a participant in the area's tobacco industry in her own right. Yet, the details of Loreto's life reveal the intertwined relationships between enslaved and free black members of rural Cuban society and their white counterparts, and the definitive connection between tobacco and freedom. Like other slaves who purchased their freedom, the young caravali woman was bought by one of the area's white vegueros, Jacinto Morejon around 1775 when she was approximately 17 years old. As with other slaves who eventually earned the money needed to free themselves from slavery, her new owner was a long-standing tobacco farmer, growing tobacco in the partido of Consolación since at least 1770.396

It is possible that some of the funds used for Loreto's manumission in 1788 came from economic transactions related to tobacco, both her own and those of her husband. In

395 . de Lamadriz, "Resumen general...Nueva Filipina...," 1 July 1787, legajo 1407, PC, AGI; de Villeras, "Resumen general...Nueba Poblacion de Filipina...," 1 April 1788, legajo 1407, PC, AGI.

396 . Jacinto Morejon to María Loreto, libertad, 18 July 1788, Consolación, expediente 413, Book 1 (1775-1789), PN, EG, AHPPR; "Tazmia de los tavacos del Partido de Consolación...," Duarte, Consolacíon, 1770, legajo 1094, PC, AGI. 
1779 , the still-enslaved Loreto actively sought to earn the money necessary to purchase her manumission, taking advantage of her new owner's choice of profession and growing tobacco on her own account, making her one of only two vegueros of color and the only black woman among the 30 tobacco farmers in the Consolacion district. ${ }^{397}$ The man who would become her husband, free black (moreno libre) veguero José Antonio Ribero owned tobacco land by at least 1784 when he bought a vega, located southeast of the villa of Consolacíon del Sur and bordering the Herradura River and the Camino Real, from white veguero Dionisio Manrresa. On March 27, 1786, Ribero sold the property, described as enough land for one man to work, to white veguero Don Anzieto Morejon for 170 pesos. Between the spring of 1786 and fall of 1788, Ribero died. On July 18, 1788, the now-30-year-old Loreto purchased her freedom, paying Jacinto Morejon 300 pesos. By that fall, she was widowed and continued the pattern of land transactions first initiated by her husband. ${ }^{398}$ Ribero's widow on October 18 sold Anzieto Morejon additional tobacco land located in the same area as the vega he had purchased two years earlier from her husband. Large enough for one man to work, the property sold for 160 pesos, but Morejon was unable to pay for the entire transaction, instead signing a

397 . Ramón Lloret, "Tazmia correspondientes a los Partidos of San Juan y Martinez, Guane del Sur, Pinar del Rio, Consolacion, Palacios, y San Cristobal," 1 June 1779, San Juan y Martínez, legajo 1261, PC, AGI.

398 . Lloret, "Tazmia de tabaco, Partidos de San Juan y Martínez..." 1 June 1779, legajo 1261, PC, AGI; José Antonio Ribera to Don Anzieto Morejon, venta de vega, 27 March 1786, Filipinas, folio 503v, expediente 317, Book 1 (1775-1789), PN, EG, AHPPR; Loreto to Morejon, venta de vega, 18 October 1788, Filipina, folio 634v, Book 1 (1775-1789), PN, EG, AHPPR; Morejon to Loreto, Letter of Freedom, 18 July 1788, Consolacíon, expediente 413, Book 1 (1775-1789), PN, EG, AHPPR. 
promissory note for 90 pesos that same day. Under the terms of the agreement, he agreed to pay Loreto 20 pesos at the end of eight days, 20 additional pesos in two months, and the remaining 50 pesos from the funds he would receive from his 1789 tobacco crop. Acting as María Loreto's representative in both 1788 transactions was a white fellow veguero and slave owner, Captain Bartolome Diaz. ${ }^{399}$ These tazmias and real estate records demonstrate the very real possibility that Loreto, her husband Ribero, or both earned the money for her manumission from the sale of tobacco to the royal monopoly, and document the existence of economic transactions between free people of color and whites. More importantly, however, they also allude to the status and integration of the Ribero-Loreto family into Filipinas's society, which undoubtedly came from their longstanding position as freed people, property owners, and vegueros.

Distance between the pueblos of San Juan y Martínez and Pinar del Río did not impede economic transactions between their residents. In 1775, Pinar del Río tobacco farmer Agustin Murquia sold a Mina slave, Antonio Bentura to Domingo González, both discussed in detail above, who lived in San Juan y Martínez. Like González, Murquia had spent many years working tobacco, owning a vega in the Pinar del Río district by at

399 . Loreto to Morejon, venta de vega, 18 October 1788, Filipina, folio $634 \mathrm{v}$, Book 1 (1775-1789), PN, EG, AHPPR; Don Anizeto Morejon to María Lorento, obligacíon, 18 October 1788, Pinar del Río, folio 636v, expediente 423, Book 1 (17751789), PN, EG, AHPPR. For Bartolome Diaz as a veguero and slave owner, see José de la Torre to Sgt Felipe Rocha, venta de vega, 17 September 1778, folio 190v, expediente 119, Book 1 (1775-1789), PN, EG, AHPPR; Sub Tte Bartolome Diaz to Paulina de Armes, Letter of Freedom, 25 August 1784, expediente 255, Book 1 (1775-1789), PN, EG, AHPPR; Antonio de Puentes to Bartolome Diaz, venta de esclavo, 24 November 1780, expediente 149, Book 1 (1775-1789), PN, EG, AHPPR. 
least 1770.400 In 1778 and 1779, he expanded his holdings, purchasing one farm located along the Sequito River from Julio Delgado in September of 1778 . The property was exchanged for just 50 pesos but included a house, a tobacco barn, and a kitchen. Murquia bought another farm, described as a $13 / 4$ caballeria (approximately 41 acres) sitio located in the paraje of San Antonio near Havana from Rosendo Madera in July of 1779 for 800 pesos. $^{401}$

\section{The Business of the King's Crop}

During the 1760 s, tobacco production in the Guane district remained low, never exceeding 2,000 arrobas (approximately 50,000 pounds) per year except for one, particularly as compared to other districts such as Xiaraco that regularly produced in

400 . de Paula Mari, “Tasmia...Pinal del Rio...," 2 June 1770, Pinar del Rio, legajo 1094, PC, AGI. He still owned the farm the following year, see de Paula Mari, “Tasmia...Partido de Pinal del Rio," 29 May 1771, Pinar de Rio, legajo 1096, AGI. Murquia and his wife, María Gertrudis Pita Armenteros, daughter of don Blas Pita and doña Micaela Armanteros, both naturals of Havana and deceased by September 1775, were the parents of at least 3 living children including local militia captain Mariano Murquia. Pita Armenteros's dower consisted of 329 pesos in gold and at the time that she made her will she owned 8 slaves, 5 mules, and a pair of oxen. See María Gertrudis Pita Arenteros, testament, 24 September 1775, Pinar del Río, folio 45, Book 1 (1775-1789), PN, EG, AHPPR.

401 . Julio Delgado to Don Agustín Murquia, venta de vega, 11 September 1778, folio 188v, expediente 118, Book 1 (1775-1789), PN, EG, AHPPR; Rosendo Madera to Agustin Murquia, venta de asiento de vega, 11 July 1779, Pinar del Río, folio 213, expediente 141, Book 1 (1775-1789), PN, EG, AHPPR. Adjacent to vegas owned by Rosendo Madera and Don José de la Torre, Delgado acquired the land from Rosendo Madera approximately eight years before. The other property was located in the jursdiction of the city of Havana, bordering sitios owned by Lorenzo Madera and Matias Gonzalles. The previous owned had purchased the land from Chistoval Gonzáles 5 years prior. 
excess of 5,000 arrobas. What the region may have lacked in quantity of tobacco delivered to the monopoly, it made up for in quality. The official, set prices for tobacco varied based on the quality of the leaf, but farmers complained that standardized prices for similar quality tobacco varied in different parts of the island. ${ }^{402}$ Their charge was justified. Prices were consistently set at disparate levels for the different partidos throughout the period examined by this study, and the Vuelta-Abajo region, known for its superior tobacco, regularly received among the highest prices paid. Beginning in 1765 through the end of the 1770s, vegueros from the Guane district received the highest prices, 40 reales per arroba for their top grade of tobacco, described as limpio (clean). In contrast, Xiaraco's vegueros earned 35 reales for each arroba of their highest grade tobacco, described as largo (long). ${ }^{403}$ As late as 1797, farmers in the Vuelta Abajo received 51 reales per arroba (the equivalent of 25 pounds) for one of the highest quality grades, "limpio" (clean), while vegueros in Govea received a mere 35 reales for the same grade. ${ }^{404}$ Unfortunately for the rest of the island's vegueros, this price differential

402. Antonio María Bucarely to Sr. Bentura Doral, 31 March 1766, Puerto Principe, legajo 1077, PC, AGI; Antonio María Bucarely to unknown, 17 May 1771, Havana, document 42, legajo 1077, PC, AGI; Notice, 10 November 1782, Filipinas, legajo 1317, PC, AGI. This was also the case in Mexico. When Teusitlan was included in the growing area in 1764, the price for their tobacco was set lower because it was determined that their tobacco was of lower quality.

403. Manuel Ramírez de Arellano, "Estado que manifiesta los distintos precios á que se ha pagado cada arroba de Tabaco á los Labradores de este fruto, desde el establecímiento del Ramo por cuenta de la Rl Hacienda el año de 1761 hasta el presente de 1804," 4 August 1804, Real Factoría de Tabacos de la Havana, table 10, signatura 9454, legajo 209, RC, ANC.

404 . unsigned, "Copia del Estado remitido por el Director General de la Factoría con carta de 14 de July de 814 n. 152 en que se manifiesta los distintos precios á que se 
continued well into the nineteenth century. In 1803, vegueros in the Vuelta Abajo received 70 reales per arroba for their "limpio" class tobacco, while tobacco farmers in another district earned only 48 reales per arroba for the same grade tobacco..$^{405}$

\section{Contraband and the Lure of the Devil's Weed}

Like those in other parts of the island, Filipinas' vegueros were accused by the monopoly of failing to deliver all of their tobacco. In early November of 1782 , the captain of the district, Gabriel de Mier, noted that 26 individuals had failed to turn in the tobacco recorded on that year's tazmia. The amounts in question ranged from a mere 25 sticks belonging to Blas Biamonte to 280 cujes of tobacco grown by José Antonio Martín. Two slaves owned by the Padres de Belen failed to turn in 60 sticks of tobacco, while a free black man named Francisco was cited with not delivering 50 cujes. In all, 2,325 sticks of tobacco out of the 14,898 cujes, or about 13 percent, of the entire 1782 harvest were unaccounted for in the area. ${ }^{406}$ Just several years later, another resident of the area was even more blatant in his attempt to defraud the tobacco monopoly. In an attempt to

ha contratado la arroba de Tabaco segun sus clases en los diversos Partidos de la Ysla de Cuba con los Diputados de los Labradores," no date (after 1813), legajo 2001, SD, AGI.

405 . "Copia del Estado remitido por el Director General de la Factoría con carta de 14 de July de 814 ..." no date (after 1813), legajo 2001, SD, AGI.

406 . de Mier, "Noticia de los Yndividuos que se han negado...," 10 November 1782, Filipina, legajo 1317, PC, AGI; de Mier, "Tazmia...Partidos de la Buelta de Abajo...," 15 June 1782, Filipina, legajo 1317, PC, AGI. 
"misdirect" tobacco, Cristobal de Cordova forged the capitan del partido's signature, but was caught and was turned over to authorities. ${ }^{407}$

Tobacco from Filipinas was particularly prized, and drew the interest of contrabanders. In the fall of 1767 , contraband tobacco from the Vuelta Abajo was found hidden near Bejucal, just outside of Havana. On October 6, a local authority informed Captain General Bucareli that a total of 59 horses, 24 owned by Francisco Pérez, 16 by Andres de País, and the remaining 19 by don Vicente Pita, were ready to return the tobacco to Havana. Just two days later, Francisco Jacott wrote that more Vuelta Abajo tobacco was found and also would be remitted. He had requested 83 horses in all, and anticipated they would arrive in Havana on the nineteenth, he told Bucareli. By late November, however, it was clear that there was a problem. Not enough animals to carry the tobacco were available, and five that were unsuited for the task had already died. ${ }^{408}$ In February 1774, 18 tercios of tobacco from the Vuelta Abajo along with other contraband items were recovered on a farm belonging to Antonio Alfonso located in Cruz del Padre and taken to the Real Factoría. ${ }^{409}$ The Marqués de la Torre promptly contacted Nicolás Rapun, the intendant and head of the tobacco monopoly, suggesting that, while the final decision was Rapun's, the usual penalty was 50 ducados each for the seller and

407 . José de la Torre to Luis de Unzaga, 1 August 1784, Pinar del Río, legajo 1350, PC, AGI.

408 . Francisco Tacott to Antonio María Bucareli 6 October 1767, Bejucal, legajo 1090, PC, AGI; Tacott to Bucareli 8 October 1767, Bejucal, legajo 1090, PC, AGI; Alcaldes de Bejucal to Bucareli, 29 November 1767, Bejucal, legajo 1090, PC, AGI.

409. Mateo de Echevarria to Marqués de la Torre, Santiago de Cuba, 16 February 1774, legajo 1156, PC, AGI. 
purchaser of illicit tobacco could be raised to 100 ducados for Alfonso since the seller of the tobacco was unknown in this case. ${ }^{410}$

Charges of contraband grew more frequent during the first decade of the nineteenth century. A citation was issued against veguero Juan de Acosta from the San Juan y Martínez district who was accused of withholding 25 sticks of tobacco from his 1803 harvest. In response to this charge from the captain of the partido, Don Amonio de Puentes, de Acosta claimed that he had failed to turn in the tobacco because he was "gravely ill" and argued that the amount was just 15 cujes, with the remaining 10 for his own personal use.411 A 35-year-old muleteer was questioned about this, but claimed that he had no knowledge of clandestine trade or any individuals involved in such illegal activity. ${ }^{412}$ In 1809, Pinar del Río district vegueros Silvestre de Torres, Marcos Ramos, María Ignacia Alvarez and her brother Antonio Alvarez, free black Francisco Gato, Bartolo Montiel, José Madera and doña María Gertrudis Duarte were cited by the area's second-ranking tobacco monopoly representative (factor subalterno) don Juan Gregorio Nuñez for not presenting tobacco registered to them in the tazmia. ${ }^{413}$ Nuñez suggested that the tobacco in question could have been placed in the barn to cure after the tazmia

410 . Marqués de la Torre to Nicolas José Rapun, 16 February 1774, Havana, document 530, folio 584, legajo 1154, PC, AGI.

411. Auto, Delito oficial contra Juan de Acosta veguero del partido de San Juan y Martínez sobre averiguar el destino que oio a su cosecha de tabaco el año anterior, 21 February 1804, Ciudad de la Habana, number 26, legajo 1003, IGH, ANC.

412. Boid.

413 . Juan Gregorio Nuñez to Don Ignacio Alvarez de la Cruz, 23 August 1809, Pinal del Río, legajo 1060, IGH, ANC. 
was made. He speculated, however, that it was more likely that suspects sold their best tobacco in the immediate area, and delivered their lowest class of tobacco, so as to somewhat comply with the monopoly's regulations. ${ }^{414}$ As the details surrounding the case progressed, one official commented that the connection between the vegueros and those who purchased the tobacco was "most interesting." 115 Unlike the vegueros, who could be excused somewhat because they committed the crime out of necessity, Nuñez found those who bought the illicitly obtained tobacco as "more guilty" than the vegueros, and noted that they should be treated with "more severity." 416

As was the case in Havana, tobacco's fate was uncertain even after it reached the relative safety of the monopoly. At one in the morning on January 12,1785 , a building in Consolación used to store tobacco destined for the royal monopoly was consumed by fire. The residents fought all day to completely extinguish the flames, but, despite their best efforts, were unsuccessful and 89 tercios of tobacco were destroyed. Writing to intendant Luis de Unzaga on January 14, José María de la Torre, the local capitan del partido, noted that the culprit had not yet been found, but various individuals suspected of involvement in the crime had been jailed. ${ }^{417}$

414. Juan Gregorio Nuñez to Superintendente Director General, 20 October 1809, Palacios, legajo 1060, IGH, ANC.

415. Antonio Daza Maldonado to Superintendente Director General, 25 November 1809, Habana, legajo 1060, IGH, ANC.

416. Ibid.

417 . José María de la Torre to Luis de Unzaga, 14 January 1785, Consolación, legajo 1350, PC, AGI. 
Like other locations throughout the island, an examination of Nueva Filipinas' tobacco growers reveals a far more complex group of individuals than the current historiography leads one to believe. The vegueros of far western Cuba were comprised of virtually all sectors of colonial Cuban society including free and slave, white and black, rich and poor, not unlike their counterparts in Güines, Trinidad, or Santiago de Cuba, for example. Together, these individuals produced some of the world's most renowned agricultural product, while attempting to earn a living within the confines of a technically strict monopoly on their crop. Yet, as would be the case with tobacco farmers island wide, they found ways to circumvent the Real Factoria de Tabacos by selling to nonauthorized entities. 


\section{Chapter 5:}

\section{The Business of the King's Crop}

Tobacco use became widespread following its introduction to Europe. ${ }^{418}$ As early as 1605 , England consumed an estimated 130,000 pounds of Spanish tobacco worth $£ 200,000$ sterling. When Virginia tobacco came on the market, Spanish tobacco imports to England dropped to just 50,000 pounds by 1615 . Just four years later, tobacco imports from Virginia surpassed those from Spain and Portugal. ${ }^{419}$ Although Spain lost its foothold in the British market, its own citizens eagerly filled the gap, with tobacco consumption exceeding 2.8 million pounds in just one year alone. ${ }^{420}$

Despite its popularity, not all members of European society found tobacco use acceptable. England's King James I in his 1604 Counterblaste strongly denounced smoking, describing it as "a custome lothsome to the eye, hateful to the nose, harmfull to the braine, dangerous to the Lungs, and in the black stinking fume thereof, neerest

418 . The spread of tobacco throughout Europe and the world is documented in detail in an earlier chapter. "Tobacco permeated all European social classes at about the same time, in contrast to other exotic substances of the period such as sugar, chocolate, coffee and tea, all of which appear to have entered at the top and percolated downwards." Goodman, The Cultures of Dependence, 47.

\section{9 . Leví Marrero, El siglo XVII (II), vol. 4 of Cuba: Economía y sociedad} (Madrid: Editorial Playor, 1975), 38-39.

420. The year was 1755. Agustín González Enciso, "Los Usos Financieros del Tabaco; o Bien, para Qué Servían los Dineros Obtenidos con la Renta del Tabaco," in $E l$ Mercado del Tabaco en España Durante el Siglo XVIII: Fiscalidad y Consumo, edited by Santiago de Luxán Meléndez, Sergio Solbes Ferri and Juan José Laforet (Las Palmas de Gran Canaria: Universidad de Las Palmas de Gran Canaria Servicio de Publicaciones, 2000), 40 . 
resembling the horrible Stigian smoke of the pit that is bottomlesse." "421 The British king even denounced Sir Walter Raleigh, who was credited for introducing tobacco to England. ${ }^{422}$ The Swiss Protestant Church, particularly in the Canton of Bern, called tobacco use the seventh most objectionable act against the Law of God. ${ }^{423}$ The Catholic Church was similarly opposed to tobacco, and in 1624, Pope Urban VIII issued a papal bull that threatened anyone using tobacco on church grounds with excommunication. The measure did little to curb tobacco use and later that century Popes Innocent $\mathrm{X}$ and Innocent XI were forced to reissue the pronouncement. ${ }^{424}$ Across the globe, those caught using tobacco faced severe penalties. The czar of Moscow ordered the noses of snuff users to be cut off, while Persia's Shah Abbas-Sofi demanded the death penalty for anyone using tobacco in any form. ${ }^{425}$ Not even members of the clergy were immune from punishment. Five Catholic friars discovered smoking in the choir during church services were sentenced to death in 1692 and entombed in the walls of a building in Santiago de Compostela, Spain. ${ }^{426}$

421. Ortiz, Cuban Counterpoint, 224.

422 . Ibid., 224-25.

423 . M.J. Gornes Mac-Pherson, De la conquista a nuestros dias: Historia del tabaco (Caracas: Editorial "Elite", 1933), 6.

424. Ortiz, Cuban Counterpoint, 234-35.

425. Gornes Mac-Pherson, De la conquista a nuestros dias, 6.

426. Ortiz, Cuban Counterpoint, 234-35. 
The eighteenth century saw a shift toward acceptance of tobacco, a sharp contrast to earlier opposition. Tobacco consumption clearly was unstoppable, and ultimately European royal houses saw the potential for great profit by cashing in on this new habit. One or another form of tobacco monopoly sprang up throughout the continent and their overseas colonies during this period. ${ }^{427}$ Even the Catholic Church joined in this new acceptance of tobacco. In 1725, Pope Benedict XIII permitted the use of snuff inside St. Peter's Basilica, and fifty-four years later the Papacy sought to capitalize on the economic potential of tobacco and opened its own factory. ${ }^{428}$

Spain's earliest approaches to tobacco control were influenced by the plant's success as a contraband product. In 1606 , royal officials prohibited all tobacco cultivation for ten years in Santo Domingo, Cuba, Margarita, Puerto Rico, Cumaná, and

427 . For British regulations regarding tobacco, see C.M. MacInnes, The Early English Tobacco Trade (London: Kegan Paul, Trench, Trubner, and Company, 1926); Alfred Rive, "A Brief History of Regulation and Taxation of Tobacco in England," William and Mary Quarterly 2nd ser. 9, no. 2 (April 1929): 73-87. For controls on tobacco in Britain's American colonies, see Aycock, "Tobacco Regulation in Colonial Virginia,"; Saloutos, "Efforts at Crop Control in Seventeenth Century America,"; Mary McKinney Schweitzer, "Economic Regulation and the Colonial Economy: The Maryland Tobacco Inspection Act of 1747," Journal of Economic History 40, no. 3 (September 1980): 551-69; Vertrees J. Wyckoff, Tobacco Regulation in Colonial Maryland (Baltimore: Johns Hopkins Press, 1936). The definitive work on the French tobacco monopoly is Jacob M. Price, France and the Chesapeake: A History of the French Tobacco Monopoly, 1674-1791, vol. 1 (Ann Arbor: University of Michigan Press, 1973). For the Portuguese tobacco monopoly, see Catherine Lugar, "The Portuguese Tobacco Trade and Tobacco Growers of Bahia in the Late Colonial Period," in Essays Concerning the Socioeconomic History of Brazil and Portuguese India, Dauril Alden and Warren Dean (Gainesville: The University Presses of Florida, 1977), 26-70; Carl A. Hanson, "Monopoly and Contraband in the Portuguese Tobacco Trade, 1624-1702," LusoBrazilian Review 19, no. 2 (Winter 1982): 149-68.

428. Goodman, The Cultures of Dependence, 78. 
Nueva Andalucía, hoping that such action would prevent smuggling. Unfortunately for

Spain, tight government control encouraged only more smuggling. The governor of

Cumaná lamented just one year later in a letter to the Crown, "“Tobacco has been one of the chief factors causing these coasts to be so much frequented by pirates, by reason of the great demand there has always been for it; and in truck for it they give merchandise that comes cheaper than if it were bought in Spain." ${ }^{429}$ Officials determined that more stringent measures were needed by the 1630 s. In 1636, the Crown responded by creating an official tobacco monopoly in Castile, making Spain among the first European nations to control the tobacco industry. 430 Devised to add much-needed funds to royal coffers, the monopoly was an unexpected choice, at least from a juridical point of view.

"Contemporary jurists viewed royal monopolies as an illicit way for sovereigns to raise

429 . Willem Wubbo Klooster, "Illicit Riches: The Dutch Trade in the Caribbean, 1648-1795," Ph. D. Diss. (Netherlands: Rijksuniversiteit te Leiden, 1995), 26.

430. Marcy Norton, "The Business of Tobacco in the Spanish Empire, 15901636," Working Paper No. 99-00 in International Seminar on the History of the Atlantic World, 1500-1800, Working Papers (Cambridge: Harvard University, 1998), 14-15. England's King James I assumed the sole importation of tobacco in 1613. Measures to control tobacco were extended to its American colonies as early as 1619, when Virginia passed statutes to ensure that, despite the popularity of tobacco cultivation, the colony maintained some sort of agricultural diversity. Aycock, "Tobacco Regulation in Colonial Virginia," 12, 17-35. Like the English, the French also wanted to reap the economic benefits of increased tobacco consumption. Beginning in 1621, the government placed export duties on tobacco entering or leaving the nation's so-called Five Great Farms. By 1625, Louis XII's chief minister, Cardinal Richelieu added tobacco to the growing list of taxed items. A tobacco monopoly was created in 1674, again as a revenue-raising measure. Price, France and the Chesapeake, 11-12, 17-19, 124-26. 
revenues, since they were consumption taxes in disguise (which required the consent of the Cortes) and unfairly raised prices on basic necessities." 431

The death of Spain's last surviving Hapsburg monarch, Carlos II, in 1700 led to the ascension of a new royal line to the throne. ${ }^{432}$ Under Bourbon rule, monarchs were stronger and more effective at governing than they had been under the Hapsburgs. ${ }^{433}$ Numerous economic, military, administrative, and cultural reforms were implemented during this time. One such measure included extending the royal monopoly on tobacco to Spain's overseas empire. As would be the case with many other Bourbon Reforms, Cuba served as the testing ground for the tobacco monopoly. 434 15.

431. Norton, "The Business of Tobacco in the Spanish Empire, 1590-1636," 14-

432. The succession of the Bourbons to the Spanish throne was not a simple one. See John D. Bergamini, The Spanish Bourbons: The History of a Tenacious Dynasty (New York: G.P. Putnam's Sons, 1974), 21-37 for the difficulties involved in naming a new heir.

433 . Bergamini, The Spanish Bourbons, especially 21-27 and 74-75. John Lynch disagrees, arguing "...Bourbon Spain was the same Spain as Habsburg [sic] Spain. The new dynasty did not suddenly transform the lives of the Spaniards, improve the quality of their government, or increase the power of their country. The year 1700 was not a parting of the ways, a transition from weak to strong monarchy, from old to new empire, from depressed to buoyant economy. The decades before and after 1700 were a continuation of the unbroken course of Spanish history, merging into a middle ground of proximate solutions to permanent problems." John Lynch, Bourbon Spain, 1700-1808 (Oxford, UK: Basil Blackwell, 1989), 1.

434. Although the historiography on the Bourbon Reforms is extensive, few scholars have focused the reforms in Cuba, despite the island's pioneering role. Several studies provide a notable exception however. They include Kuethe, $\mathrm{Cu} b a, 1753-1815$; Allan J. Kuethe and G. Douglas Inglis, "Absolutism and the Enlightened Reform: Charles III, the Establishment of the Alcabala, and Commercial Reorganization in Cuba," Past and Present: A Journal of Historical Studies 109 (November 1985): 118-43; Johnson, Social Transformation. 
On April 11, 1717, Spanish King Felipe V created a royal monopoly, or estanco, on Cuban tobacco. Without tobacco from the island, Spain had been forced to purchase it elsewhere, the king argued. ${ }^{435} \mathrm{Up}$ to this point, no more than 3 million pounds of Cuban tobacco had been produced in any one year, but after a review of the island's tobacco industry, royal officials indicated that up to 7.3 million pounds of tobacco worth between 6 and 7 million pesos of revenue to the Spanish treasury were possible. While most of this anticipated tobacco would be destined for Spain and its colonies, an estimated 1.5 million pounds were intended for foreign export. ${ }^{436}$

Spain used Cuba to develop and perfect the organization and administration of its tobacco monopoly. Organized under the name Real Factoría de Tabacos (Royal Tobacco Factory or Monopoly), the monopoly would be administered on the local level by agencies, known as factorias, established at four locations in Cuba (Bayamo, Trinidad,

435 . Felipe V, "Instrucción dada por Felipe V el día 11 de abril de 1717 para el estanco de tabaco," in Documentos para la historia de Cuba, vol. 1, Hortensia Pichardo (La Habana: Editorial de Ciencias Sociales, 1971), 147; José Rivero Muñiz, Las tres sediciones de los vegueros en el siglo XVIII (La Habana: Academia de la Historia de Cuba, 1951), 20-22.

436. McNeill, Atlantic Empires of France and Spain, 118; Leví Marrero, Del monopolio hacia la libertad comercial (1701-1763) (II), vol. 7 of Cuba: economía y sociedad (Madrid: Editorial Playor, 1978), 45-46. The documents creating Mexico's royal tobacco monopoly stressed that the estanco was created as a revenue-making venture to cover the increasing costs of defending the Spanish Empire, an objective only fueled by the loss of Havana to the British. See David Lorne McWaters, "The Royal Tobacco Monopoly in Bourbon Mexico, 1764-1810," Ph. D. Diss. (Gainesville: University of Florida, 1979), 30. The Philippine Islands' tobacco monopoly was organized under the same hopes as well. See Ed.C. de Jesus, The Tobacco Monopoly in the Philippines: Bureaucratic Enterprise and Social Change 1760-1880 (Manila: Ateneo de Manila University Press, 1980), 29. 
Sancti Spíritus, and Santiago de Cuba), and six locations elsewhere in the Empire.

Tobacco would be categorized, graded, and priced according to its quality. In an attempt to circumvent any potential opposition to the new monopoly, officials set the official prices for tobacco similar to those previously received by the vegueros. ${ }^{437} \mathrm{~A}$ violent uprising in 1717 by the tobacco farmers, and the expulsion of Cuba's captain general made enforcement of the new monopoly virtually impossible. Only with the return of Spanish governance to the island in the form of the new captain general, Gregorio Guazo Calderón, did the monopoly become reestablished. A royal order dated December 16, 1718 named Manuel de León y Navarro as the monopoly’s director general. Local monopoly agencies were reestablished in the same locations as before. Hoping to prevent another uprising, the monopoly was given instructions to have sufficient funds on hand in order to pay the tobacco farmers for their crop. .38

Resistance to the monopoly continued, however, particularly from the clergy, and a second veguero revolt followed. Beginning in late October of 1720 , and expanded the following month, the Crown allowed Cuba's vegueros to freely sell any surplus tobacco remaining once the monopoly's needs were met. Cuba's tobacco farmers were not

437 . Rivero Muñiz, Tabaco, vol. 1, 90-94; McNeill, Atlantic Empires of France and Spain, 118, 256. McNeill argues, however, that the fixed prices were "notably lower" than those paid in 1700 .

438. Marrero, Del monopolio hacia la libertad comercial (1701-1763) (II), vol. 7 of Cuba: economía y sociedad, 50. 
appeased,and again revolted in February of 1723.439 Although the regulations of the monopoly frequently changed over the next hundred years, and official control of Cuba's tobacco monopoly passed through many hands, the Crown found the endeavor to be a success and by the end of the eighteenth century virtually every Spanish colonial entity capable of growing tobacco had instituted a royal monopoly. ${ }^{440}$

Spain was disappointed with the monopoly's first attempts and on June 17, 1724, King Luis I, who occupied the throne for only seven months before he died, decided to temporarily suspend the monopoly's activities in Cuba. Not only had the farmers reacted violently to control of their industry, the tobacco sent to Spain was of poor quality and was not enough to fulfill the needs of the monopoly. Meanwhile, Cuba's best-quality tobacco was smuggled off the island and sold elsewhere. ${ }^{441}$ By 1727 , the monopoly was reorganized and given the name, Intendencia General de Tabaco (General Intendancy of Tobacco). Its first head was Martín de Loynaz, a high-ranking Spanish official formerly

439 . Rivero Muñiz, Las tres sediciones; Juan Jiménez Pastrana, La rebelión de los vegueros (La Habana: Editorial Gente Nueva, 1979). The three veguero uprisings are described in greater detail in Chapter 1.

440 . For a history of the Cuban tobacco monopoly, see José Rivero Muñiz, Tabaco: Su historia en Cuba, vol. 1-2 (Havana: Instituto de Historia, 1964-65); H.E. Friedlaender, Historia economica de Cuba, vol. 14 (La Habana: Jesus Montero, 1944), 64-73; McNeill, Atlantic Empires of France and Spain, 118-22; María del Carmen Barcia, "Clases sociales y tabaco: comentarios en torno a su producción y estanco (desde sus inicios hasta principios del siglo XIX," Santiago 65 (June 1987): 120-41. Tobacco monopolies were established, among other locations, in Peru (1745), Chile and La Plata (1753), Santo Domingo (1754), Guatemala (1766), Colombia (1778), Venezuela (1779), and Puerto Rico (1785). McWaters, "Royal Tobacco Monopoly in Bourbon Mexico," 11$12,24$.

441. Marrero, Del monopolio hacia la libertad comercial (1701-1763) (II), vol. 7 of Cuba: economía y sociedad, 52-56. 
in charge of the renta de tabacos (tobacco monopoly) in Spain. ${ }^{442}$ Although the period from 1725 to 1733 was one of "relatively free trade," the contraband traffic in Cuban tobacco expanded, and the island was unable to provide the requested 3 million pounds of tobacco per year. ${ }^{443}$

Hoping that private leadership would improve the situation, Spain farmed out the monopoly by 1734 . Cadiz businessman José Tallapiedra ran the now-privately controlled monopoly from 1735 to 1738 , when management shifted to Francisco Sánchez de Madrid, the Marqués de Casa-Madrid. With the creation in 1741 of the Real Compañia de Comercio de la Habana (Royal Commercial Company of Havana), which oversaw not only tobacco but also other agricultural products, administration of the tobacco monopoly changed again. ${ }^{444}$ An investigation of the company's practices during the $1750 \mathrm{~s}$, however, revealed that the Real Compañia had violated the terms of its charter and presented false statements to authorities in 1746 and 1747. As a result, the Real

442 . Ibid; McNeill, Atlantic Empires of France and Spain, 115.

443 . Jacobo de la Pezuela, "Tabaco," in Diccionario geográfico, estadistico, histórico de la Isla de Cuba, vol. 4 (Madrid: Imprenta del Establecimiento de Mallado, 1867), 566.

444. Marrero, Del monopolio hacia la libertad comercial (1701-1763) (II), vol. 7 of Cuba: economía y sociedad, 58; McNeill, Atlantic Empires of France and Spain, 11921; "Establiciendo una Compañía en San Cristóbal de la Habana Dedicada a la Conducción de Tabacos, Azúcar, Corambre y Otros Frutos de la Isla de Cuba," in Cédulas de Luis I (1724), Cédulas de Felipe V(1724-1746), vol. 3 of Cedulario Americano del Siglo XVIII, edited by Antonio Muro Orejon (Sevilla: Escuela de Estudios Hispano-Americanos, 1740), 253-76. Havana's Calle de Tallapiedra, a two-block long street located outside of the city's walls between Calle Suárez and Calle del Aguila was named for tobacco monopoly head José Tallapiedra. Manuel Pérez-Beato, Toponomia, vol. 1 of Habana antigua (Habana: Seoane, Fernández y Ca., 1936), 229. 
Compañia lost its right to the tobacco trade, and the monopoly was again reorganized in 1761, this time as a government agency known as the Nueva Factoría de Tabacos de la Habana (New Tobacco Factory of Havana). ${ }^{445}$

During the British occupation of Havana from August 1762 to July 1763, Cuban officials attempted to secure the right for Spain's king to purchase tobacco from the areas under English control, but the request was denied. Although the monopoly's head, José Rapún, remained in the city, the entity had little control over tobacco and the junta (monopoly board) did not meet. The British occupiers seized 244,557 pesos belonging to the tobacco monopoly, and purchased tobacco from growers at double the price paid by the Spanish. Outside of the occupied areas, little changed for farmers in the central and eastern part of the island, however, particularly since a tobacco official had managed to send 174,748 pesos to purchase that year's crop before the siege began. ${ }^{446}$ When the Cuban capital returned to Spanish control, the monopoly resumed its functions.

Cuba's tobacco monopoly, in theory, was responsible only to the Spanish Crown and its designated representatives. While each of these functions had many components,

445 . Rivero Muñiz, Tabaco, vol. 1, 225-36.

446. Ibid, 237; Celia María Parcero Torre, La pérdida de la Habana y las reformas borbónicas en Cuba, 1760-1773 (Madrid: Consejo de Castilla y León, 1998), 178, 183-84, 187. With Cuba focused on the British, nearby tobacco-growing regions saw an opportunity to promote their own tobacco to Spain. Santo Domingo's governor, Manuel de Azlor y Urries, sent seventeen loads of various grades of tobacco to Spain in the hopes of stepping into Cuba's spot in the tobacco market. The plan worked, and a real order created a tobacco monopoly administration district, or factoria, for the city of Santo Domingo by mid-October of 1763. Antonio Gutiérrez Escudero, "El tabaco en Santo Domingo y su exportación a Sevilla (época colonial)," in Relaciones de poder y comercio colonial: nuevas perspectivas, edited by Enriqueta Vila Vilar, Allan J. Kuethe (Sevilla: Escuela de Estudios Hispano-Americanos de Sevilla, 1999), 124. 
the monopoly's duties were three-fold: first, ensure that the tobacco mandated by the estanco entered the monopoly, and that no illegal contraband or tobacco production take place; second, pay the farmers for their product; and lastly, send the tobacco to Spain as directed. From the vegueros' point of view, however, the monopoly also had a responsibility to them. As the producers of a valuable commodity, they demanded prompt and fair payment for the tobacco they delivered to the Factoria. This was a key concern of Cuba's tobacco growers and will be discussed in greater detail later in this chapter and elsewhere in this study.

The early physical headquarters of the Cuba's royal tobacco monopoly were rather inauspicious. Located near the southern end of the Campo de Marte, the military practice and parade ground that marked the boundary between the rural outskirts and the capital itself, and the royal shipyard was a "dilapidated building that served as a warehouse" for the monopoly. ${ }^{447}$ During the 1770 s, Spain authorized construction of a new edifice to house the organization. The chosen site was located in Havana's Jesús María neighborhood outside of the city's walls. Bordering Factoría, Revillagigedo and Diario streets, the property had access to the sea via the Tallapiedra wharf. In March of 1773, at least eight houses were seized and razed to make way for the structure which would cover an entire block. The man responsible for Havana's refortification following its return from the British, director of engineers Silvestre de Abarca and royal engineer Luis Huet

447 . Sherry Johnson, "'La Guerra Contra los Habitantes de los Arrabales': Changing Patterns of Land Use and Land Tenancy in and Around Havana, 1763-1800," Hispanic American Historical Review 77, no. 2 (1997): 189; Johnson, Social Transformation, 20. 
designed the facility. Nineteenth-century visitor Alexander von Humboldt described the vast building as one of the city's "principle edifices...less notable for [its] beauty than for the soliditity of [its] construction." 448

\section{The Tobacco Monopoly's Bureaucratic Structure}

The tobacco monopoly from 1763 to 1817 was a sizable enterprise which involved virtually every branch of Cuban colonial government in one form or the other. Just over twenty years before royal control of the tobacco industry ended, the Cuban monopoly's bureaucracy included fifty people who worked in general administration, accounting, notary, and treasury functions. Together, these positions accounted for 35,714 pesos in payroll. The accounting division, the contaduria, alone employed seven people, while four individuals worked in notary functions. Eight years later, in 1804, payroll costs had risen to over 56,000 pesos, not including the head of the tobacco monopoly. ${ }^{449}$ Despite its shortcomings over the years, the bureaucratic structure and operational system of the estanco developed and tested in Cuba was eventually copied in other Spanish colonies. ${ }^{450}$

448. Levi Marrero, Azucar, ilustración y conciencia (1763-1868) (III), vol. 11 of Cuba: economia y sociedad (Madrid: Editorial Playor, 1984), 8; Hazard, Cuba with Pen and Pencil, 214-15; Johnson, Social Transformation, 84, 124; Johnson, "La Guerra Contra los Habitantes de los Arrabales"," 192; Humbolt, The Island of Cuba reprinted in Louis A. Pérez, Jr., ed., Slaves, Sugar, and Colonial Society: Travel Accounts of Cuba, 1801-1899 (Wilmington, Delaware: Scholarly Resources, 1992), 2.

449 . "Repartimiento de los empleados en la Factoría de Tabacos de la Habana aprorado por S.M. en 30 de August de 1796," legajo 2001, SD, AGI; Marrero, Azúcar, ilustración y conciencia (1763-1868) (III), vol. 11 of Cuba: economía y sociedad, 33.

450 . Rivero Muñiz, Tabaco, vol. 1-2. An abbreviated list of works on the royal tobacco monopoly throughout the Spanish Empire includes Eduardo Arcila Farias, 
At the top of the bureaucratic ladder was the highest-ranking official in Cuba, the captain general. Described as the "juez protector" (protection officer) in an eighteenthcentury document outlining the various duties of each branch of monopoly administration, the captain general was charged with furthering the island's tobacco industry. ${ }^{451}$ Among his responsibilities was ensuring that the vegueros turn in all tobacco over six inches high ("medio pie arriba") and that no tobacco was removed from the island for foreign export. Next came the Junta de Factoría (Factory or Monopoly Board) which was immediately in charge of the island's tobacco sector and directed to encourage excellent quality of the tobacco produced by the vegueros. The Junta also had the task of sending all the leaf and ground tobacco requested by Seville, as well as distributing tobacco to other parts of Spanish America including New Spain and Peru. ${ }^{452}$

Other colonial officials including Cuba's intendant, a position created in 1764 which oversaw the two essential departments of treasury and war, were responsible for assisting in the administration of the monopoly. Although the intendant had almost unlimited powers over the military, his role was somewhat limited in relation to treasury,

Historia de un monopolio: El estanco del tabaco en Venezuela 1779-1833 (Caracas: Ediciones de la Facultad de Humanidades y Educación, Universidad Central de Venezuela, 1977); Deans-Smith, Bureaucrats, Planters, and Workers; de Jesus, The Tobacco Monopoly in the Philippines; Gutiérrez Escudero, "El tabaco en Santo Domingo."; Jorge Luján Muñoz, "El establecimiento del Estanco del Tabaco en el Reino de Guatemala," V Congreso Centroamericano de Historia (San Salvador, El Salvador, 2000); Agnes Stapff, "La renta del tabaco en el Chile de la época virreinal," Anuario de Estudios Americanos (Seville) 18 (1961): 1-63.

451 . "Instrucciones para el gobierno del ramo de tabacos en la isla de Cuba," Madrid, 1796, legajo 2002, SD, AGI.

452 . Ibid. 
dealing primarily with financial concerns. As Duvon Corbitt notes, "the collection, safeguarding, auditing and expenditure of revenues and funds," increasing Cuba's revenue, and "preventing and punishing smuggling" all garnered his attention. ${ }^{453}$ Cuba's first intendant, Miguel de Altarriba arrived in Havana in early 1765 and served in this post until his health forced him to returned to the peninsula to recover his health in 1773 . Sent to Cuba to replace the ailing Altaribba was Nicolás José Rapún, a former commissioner of the navy. In early March of 1776, the Marqués de la Torre informed Minister of Finance Miguel Múzquiz that Rapún died in his sleep and that Juan Ignacio de Urriza, who had also served as navy commissioner had succeeded him. ${ }^{454}$

The third man to hold this position, Urriza would serve as Cuba's intendant from over a decade from 1776 to 1787.455 The transition was not an entirely smooth one, with two members of Cuba's colonial administration vying for the home that Rapún had previously occupied. Both the new intendant and José Antonio de Armona, the first

453 . Duvon Clough Corbitt, "The Colonial Government of Cuba," PhD dissertation (Chapel Hill: University of North Carolina, 1938), 29-30. The Marqués de Esquilache, Leopoldo di Grigorio, founded the institution, designed to improve the financial management of Havana's royal treasury and oversee military matters. Kuethe notes that while Arriaga signed the document finalizing its creation, it was indeed Esquilache who was responsible for its conception. Kuethe, Cuba, 1753-1815, $26,70$.

454 . Kuethe, Cuba, 1753-1815, 71; Levi Marrero, Azúcar, ilustración y concencia (1763-1868) (IV), vol. 12 of Cuba: economía y sociedad (Madrid: Editorial Playor, 1785), 314-316; Nicolás José Rapún, Comisario ordenador de marina, number 1, legajo 120, Ultramar, AGI; Marqués de la Torre to Miguel de Múzquiz, 7 March 1776, Havana, legajo 1227, PC, AGI. Levi Marrero inaccurately states the period of Rapún's service as $1773-1778$.

455 . Levi Marrero, Azucar, ilustración y conciencia (1763-1868) (II), vol. 10 of Cuba: economía y sociedad. (Madrid: Editorial Playor, 1984), 114. 
administrator of the mail system, claimed that the now-vacant rental property owned by Pedro José Calvo de la Puerta y Arango, the Conde de Buena Vista and one of the first nine people in Cuba to hold titles of Castile, should be theirs. Urriza argued that he should be allowed to live in the house since the one he currently occupied was too small for the new position he now held. "You know very well that the one that I currently occupy is so small that it barely holds one small family in its tightness, without giving space for the legs of the secretary, audiencia room, and other offices." he asserted to de la Torre. ${ }^{456}$ Unlike some other colonial officials, Urriza took his order to prevent contraband very seriously and was a strong opponent of such illegal trade, using "the issue to destroy other public servants less dedicated to controlling this problem." $457 \mathrm{He}$ was equally concerned with demonstrating his own successes in the war against contraband, writing to Cuba's captain general Diego José Navarro no less than fifteen times over a four month period from August to November of 1779 to inform him that tobacco intended for unauthorized sale or export had been recovered. ${ }^{458}$

456. Marqués de la Torre to Miguel de Muzquiz, 7 March 1776, Havana, legajo 1227, PC, AGI; Juan Ignacio de Urriza to Marqués de la Torre, 17 March 1776, Havana, legajo 1153, PC, AGI; Kuethe, Cuba, 1753-1815, 52; Johnson, Social Transformation, 155.

457 . Lewis, "Anglo-American Entrepreneurs in Havana," 120.

458. Juan Ignacio de Urriza to Diego José Navarro, 21 August 1779, Havana, legajo 1238, PC, AGI; Urriza to Navarro, 23 August 1779, Havana, legajo 1238, PC, AGI; Urriza to Navarro, 23 August 1779, Havana, legajo 1238, PC, AGI; Urriza to Navarro, 24 August 1779, Havana, legajo 1238, PC, AGI; Urriza to Navarro, 18 September 1779, Havana, legajo 1238, PC, AGI; Urriza to Navarro, 20 September 1779, Havana, legajo 1238, PC, AGI; Urriza to Navarro, 21 September 1779, Havana, legajo 1238, PC, AGI; Urriza to Navarro, 22 September 1779, Havana, legajo 1238, PC, AGI; Urriza to Navarro, 30 September 1779, Havana, legajo 1238, PC, AGI; Urriza to Navarro, 
Another notable man to hold the job was Rafael Gómez Robaud, a well-connected member of Spain's government and close friend of Joaquín Beltrán de Santa Cruz y Cárdenas, the first Conde de Santa Cruz de Mopos and third Conde de San Juan de Jaruco. 459 At the end of 1802, Gómez Robaud was personally selected by Minister of Finance Miguel Cayetano Soler to serve as Cuba's intendant, a job that place him among the highest government officials on the island in charge of the monopoly. In a report written after the estanco was abolished, Gómez Robaud acknowledged that he was a poor candidate for the job as it pertained to his responsibilities regarding tobacco. "Of that income and its branch, I did not have the least information or idea...," he wrote. ${ }^{460}$ To

2 October 1779, Havana, legajo 1238, PC, AGI; Urriza to Navarro, 4 October 1779, Havana, legajo 1238, PC, AGI; Urriza to Navarro, 6 October 1779, Havana, legajo 1238, PC, AGI; Urriza to Navarro, 26 October 1779, Havana, legajo 1238, PC, AGI; Urriza to Navarro, 29 October 1779, Havana, legajo 1238, PC, AGI; Urriza to Navarro, 8 November 1779, Havana, legajo 1238, PC, AGI; Urriza to Navarro, 9 November 1779, Havana, legajo 1238, PC, AGI; Urriza to Navarro, 13 November 1779, Havana, legajo 1238 , PC, AGI.

459 . Kuethe, Cuba, 1753-1815, 158. Gómez Roubaud's connection with Beltrán de Santa Cruz y Cárdenas was extremely valuable, since Beltrán de Santa Cruz was extremely well-placed in Cuban society and had particular access to the Spanish crown. The count was married to María Teresa Montalvo y O'Farill, the daughter of one of the island's richest men, the first Conde de Casa Montalvo, and was related by blood and her grandfather's second marriage to no less than four other members of Cuba's titled families, the Marqués de Real Socorro, the Conde de Casa Bayona, the Conde de Buena Vista, and the Marqués de Casa Calvo. While living in Spain in order to further his personal ambitions, Beltrán de Santa Cruz became a "gentleman of His Majesty's Bedchamber with entrance in 1792" and by the mid-1790s, he had befriended Manuel Godoy, a highly-decorated confidante of the king and the queen's young lover. Kuethe, Cuba, 1753-1815, 120, 152-54, 158; Lynch, Bourbon Spain, 385-87.

460 . Rafael Gómez Robaud, "Ynforme, Conocimientos que posé Don Rafael Gomez Roubaud en el ramo de tabacos para que pueda haber confianza en su infome," 25 January 1819, Valencia, typescript in Archivo General de Indias, Cuba, 1720-1819, vol. 25, pages 398-485, LMC, SC, GL, FIU. 
remedy that situation, he confessed that he turned to volume four of a six-volume universal dictionary written by F. Panchet in 1801 in order to learn more about tobacco, one of the most vital components of his new assignment. Nearly a year spent collecting information and visiting some of the best French snuff factories in Brittany and other locations improved his knowledge of the topic and in mid-1804, Gómez Robaud arrived in Havana ready to begin the task set before him. ${ }^{461}$

Gómez Robaud was removed from his post in 1808 , but continued on as the superintendent of the tobacco monopoly. This position, like those above and below him, required full compliance with all estanco provisions. In response to a vacancy, the superintendent was to request from the top officer of that department who would be the best replacement for the position, and offer his name to the monopoly board. As the overseer of the monopoly, he was to forward the accounting books with tobacco shipments and finances to Spain each month, as well as shipping tobacco requested by other parts of Spanish America. Most importantly, the superintendent was "the only one" who could assign funds from the monopoly's treasury to pay for payment of the tobacco farmers, employee salaries, and other such ordinary expenses. ${ }^{462}$

461. Tbid. The definitive work on France's tobacco monopoly is Jacob M. Price, France and the Chesapeake: A History of the French Tobacco Monopoly, vol. 1-2 (Ann Arbor: University of Michigan Press, 1973). His support of the island's tobacco farmers place him in opposition to monopoly advisor, Francisco Arango y Parreño. This feud, which grew to include former captain general Luis de las Casas, is detailed in Johnson, Social Transformation, 169-73.

462 . Johnson, Social Transformation, 172; "Instrucciones para el gobierno...," 1796, Madrid, legajo 2002, SD, AGI. 
With the bureaucratic headquarters located in Havana, smaller administrative districts, known as factorias, were charged with the local operation and enforcement of monopoly regulations. In 1761 , there were ten factorias throughout the island at Matanzas, Remedios, Sancti-Spíritus, Camagüey, Mayarí, Holguín, Jiguaní, Baracoa, Bayamo, and Santiago de Cuba. ${ }^{463}$ By 1796, the number had increased to eleven. Oriente Provice possessed three factorías (Santiago de Cuba, Mayarí, and Bayamo), while those in the central part of the island were located at Holguiin, Puerto Principe, Trinidad, Cayo, Ságua, and Matanzas. Nueva Filipinas, the province created in 1774 and home to the island's preeminent tobacco-growing Vuelta Abajo region, was home to two administrative districts, one located at Guane del Norte, also known as Mantua, and the other at Guane del Sur. ${ }^{464}$ By the final year of the monopoly, 1817, 25 factorias oversaw operations at the local level. Most of these newly-created administrative districts were in located in the eastern or central part of the island. Baracóa, who had lost its factoria between 1761 and 1796, again was made an administrative district, along with the new locations of Guantánamo, Giguaní, Manzanillo, Tunas, Moron, Jágua, Ságua Chica, and Villa Clara. ${ }^{465}$

463 . Friedlaender, Historia economica de Cuba, 91.

464 . "Repartimiento de los empleados..." 30 August 1796, SD 2001, AGI; Leví Marrero, Azucar, ilustración y conciencia (1763-1868) (I), vol. 9 of Cuba: economía y sociedad (Madrid: Editorial Playor, 1983), 216.

465 . José Gonzalez, "Plan demostrativo de todas las tierras que acutalmente hay destinados al cultivo de tabacos en cada partido de la isla de Cuba...," Real Factoría de Tabacos, La Habana, 31 May 1817, legajo 2019, SD, AGI. 
Each district was headed by a monopoly representative known as a factor.

Responsible for day-to-day administration, the factor was a key part in the success of the monopoly at the local level, yet this post appears to have been an unpaid one. ${ }^{466}$ In order to maintain objectivity, the factor was prohibited from personally owning a vega or participating in tobacco cultivation in any form. Reminded that he was to treat the vegueros in the "most benign and smooth manner," he was expected to visit each of the vegueros on their farms, noting their names and how many plants each vega was capable of holding. He was also the local expert on tobacco cultivation practices and instructed the farmers in the proper, approved methods including ensuring that no transplanting took place before October 15 since early plantings resulted in poor quality tobacco. ${ }^{467}$ Puerto Príncipe's local monopoly representative during the late 1760s, Joaquin de Sola, acknowledged the seriousness of his position and assured his superiors that he would not disappoint them. ${ }^{468}$ Closer to Havana along the southern coast during the same period, Fernando Muñoz served as the factor for the area around Trinidad. In July of 1768 , he complained to Cuba's captain general that he tried to prevent the hiding of or illicit trade in tobacco, but that it was difficult. Despite his frustrations, he remained at his post,

466 . "Repartimiento de los empleados..." 30 August 1796, legajo 2001, SD, AGI.

467 . "Instrucciones para el Gobierno del Ramo de tabacos...," 1796, Madrid, legajo 2002, SD, AGI.

468 . Joaquin de Sola to unknown, Puerto Príncipe, 28 June 1768, document 30, legajo 1085, PC, AGI; Ramon Buelta Flores to Antonio María Bucareli, 23 July 1769, Puerto Príncipe, legajo 1074, PC, AGI. 
faithfully serving the tobacco monopoly as its local representative until at least $1783 .{ }^{469}$

At the turn of the nineteenth century, at least three men had served as the factor for

Mayarí in eastern Cuba. The post, previously occupied by Luis de Echevarria during the mid-1760s and later by don Miguel de Villaparo, was currently held by temporary factor don Juan Francisco Girón. ${ }^{470}$

Far lower on both the bureaucratic ladder and monopoly pay scale was the warehouse guard, or guarda-almacen. A royal instruction from 1796 states that the two general guarda-almacen assigned to the monopoly in Havana should be men with great "fidelity, zealousness and activity" to ensure that the "service of the King does not suffer the least harm." 471 Among his duties were to take a general inventory of all the implements, farms, and other property belonging to the monopoly, both in Havana, and throughout the island. Assisted by the Oficial de Libros (Book Official), the amount of tobacco from each district that entered the warehouses under his control, including the name of the veguero, was recorded in another master book. The information from the physical and tobacco inventories were to be turned over to the monopoly's Treasury

469 . “...todos los Tavacos...," 13 April 1774, Trinidad, legajo 1186, PC, AGI; Fernando Muñoz, "Tasmia General que manifiesta el Numero de vegas...," 10 June 1778, Trinidad, legajo 1259, PC, AGI; Fernando Muñoz, "Notisia que manifiesta el numero de vegas...," 2 April 1783, Trinidad, legajo 1349, PC, AGI.

470 . Luis de Echevarria to Antonio Rubio, 9 July 1765, Santiago de Cuba, from Luis de Echevarria, number 10, legajo 26, CG, ANC; Matias José Duran del Castillo, Manuel Cortina, Juan Antonio Ferrera, José Serga, Ramón Barrientos, and Vicente Calderón to Intendant, 27 November 1799, Mayarí, expediente 26, legajo 1114, IGH, ANC.

471 . "Instrucciones para el gobierno del ramo de tabacos en la isla de Cuba," Madrid, 1796, legajo 2002, SD, AGI. 
Department. The warehouse guard was also responsible for the king's slaves, who should be "well-treated and with humanity," and ensure that their food supplies were purchased by the monopoly agent. ${ }^{472}$

During times of war, the guarda-almacen's duties were expanded to include other responsibilities as well. Between 1793 and 1798, royal tobacco monopoly warehouse guard Manuel Francisco de Aranguren also was charged with feeding prisoners of war held in the capital. The French prisoners, transported to Cuba from Puerto Rico by the royal frigate Nuestra Señora de la $O$ and another ship, were housed in a former hospital then known as the Casa de Pilar located outside of the city's walls. This was no small financial undertaking, however, Aranguren noted on December 31, 1793. The cost to feed the 106 surviving prisoners was roughly 5,000 pesos a month, and by the summer of 1798 , the number of prisoners had risen to 241 , and the cost of caring for them rose to 8,483 pesos monthly. ${ }^{473}$

Although the post of guarda-almacen in the Surgidero de Batabanó was among the lowest paid monopoly position, paying just 400 pesos annually as late as 1796 , the job was an extremely vital one. Responsible for receiving all of the shipments of tobacco that arrived from the southern part of the island, he was ordered to count and weigh the tercios (bundles) brought by the ship captains, ensure that they were accurate, and if not, alert the

472 . Ibid.

473. Manuel Francisco de Aranguren to Domingo Quintero, 31 December 1793, Havana, "Documentos relacionados con prisoneros de guerra francesa," expediente 60 , Asuntos Politicos (hereafter AP) 4, ANC; Manuel Francisco de Aranguren to Domingo Quintero, 15 June 1798, Havana, "Documentos relacionados con prisoneros de guerra francesa," expediente 60 , AP 4, ANC. 
monopoly's general administration. If any defects were found, the warehouse's slaves were to undo all bundles and separate them so that only uncontaminated bundles remained. Once completed, the tobacco was to be sent without delay by land to the main monopoly building in Havana, as was done with all other tobacco received by the port. To underscore the importance of this post to the success of the island's tobacco monopoly, following the decision made on February 15, 1771 by the monopoly's board for don Pedro Sanchez to replace the deceased don José de Pedraza as Batabanó's warehouse guard, even Spain's king was informed. ${ }^{474}$

Cuba's tobacco monopoly did provide ample opportunities for individuals interested in moving up the colonial bureaucratic ladder as evidence by the career of Braulio de Vivanco. Like so many other Spanish-born citizens, de Vivanco, originally from Vizcaya, Spain, came to Cuba and became part of the island's bureaucratic infrastructure. When the monopoly ended in 1817, the married, 49-year-old de Vivanco was a high-ranking tobacco monopoly bureaucrat. His association with Cuba's tobacco industry began inauspiciously in 1779 when he assisted in the division of donated tobacco land, an assignment that was unpaid. By early 1796, de Vivanco's career with the monopoly began in earnest when he was hired as second clerk in the monopoly's treasury department, with an annual salary of 500 pesos. Employed in this position for seven years and eighteen days, he rose rapidly through the ranks of the monopoly's bureaucracy. He served as head clerk for eleven-and-a-half months, then advanced to interim treasurer,

474. Julian de Arriaga to Antonio María Bucarely, Aranjuez, 24 May 1771, legajo 1140, PC, AGI. 
a position he held for four years, seven months, and twenty-eight days. On May 1, 1809, the position was made permanent and he continued in the post of general treasurer until January 1,1813, when he became the principal administrator of the tobacco monopoly. In 1817 , he advanced to his highest position, that of director general, an appointment that earned an annual salary of 3,000 pesos. Assigned to this job on August 9, he would prove to be the last to serve in this position under the monopoly. ${ }^{475}$ The end of the monopoly however did not signal the end to his association with the Cuban tobacco industry. One year later, Braulio de Vivanco still reported to Spain on issues pertaining to tobacco on the island, particularly contraband and shipments of tobacco to the Canary Islands. ${ }^{476}$ Although immediate control of Cuba's tobacco monopoly rested with those on the island, high-ranking government officials in Spain regularly were appraised of even the most minute details regarding the monopoly's decisions and day-to-day operations.

Overseeing all monopoly activity from Spain until his death in January of 1776 was the "aging, conservative, but venerable frey" Julian de Arriaga. ${ }^{477}$ As head of the Ministry of the Indies since 1754, Arriaga's position meant that he "theoretically exercised complete

475 . "Don Braulio de Vivanco y de Vizcaya su empleo director general de la Renta sueldo 3000 pesos edad 49 años estado casado sus servicios y circunstancias los que se expresan," employment record, Real Factoría de Tabacos en La Habana á la isla de Cuba, Braulio de Vivanco, circa 31 August 1817, Havana, legajo 2019, SD, AGI; "Repartimiento de los empleados en la Factoría de Tabacos de la Habana..." 30 August 1796," legajo 2001, SD, AGI.

476 . Braulio de Vivanco to Señores Directores Generales de Rentas, 15 April 1818, Havana, legajo 2019, SD, AGI; Braulio de Vivanco to Señores Directores Generales de Rentas, 3 August 1818, Havana, legajo 2019, SD, AGI.

477 . Kuethe and Inglis, “Absolutism and the Enlightened Reform,” 122. 
administrative authority over the colonies." 478 Arriaga's involvement as it related to the tobacco monopoly, however, was far more than just theoretical and included knowledge of virtually every aspect of the monopoly's operations. In just a two-year period, 1769 and 1770, this hands-on control included knowledge of contracts for Cuban tobacco mills, shipments of tobacco to Peru and the Canary Islands, meetings of the tobacco monopoly's board, and money sent from New Spain to the Real Factoría in Havana. ${ }^{479}$ Other details that did not escape Arriaga's attention included a fire in the Río de Sasa tobacco warehouse, located in the partido of Sancti Spiritus, and learning that the year's tobacco harvest would be negatively affected by a lack of rain. 480

Other high-ranking members of Spain's court also were intimately involved with Cuba's tobacco industry and monopoly. The peninsula's ministers of finance frequently addressed matters related to tobacco. In late December of 1775, Miguel de Múzquiz, the

478 . Ibid., 121-22; Kuethe, Cuba, 1753-1815, 11, 18. After Arriaga and Ricardo Wall, who held the dual positions of Spain's Minister of State and War, took responsibility for the loss of the Cuban capital to the British, Arriaga's position at court weakened.

479 . Julian de Arriaga to Antonio María Bucarely, 18 July 1769, Madrid, legajo 1134, PC, AGI; Julian de Arriaga to Antonio María Bucarely, 22 October 1769, San Lorenzo, folio 54-56, legajo 1134, PC, AGI; Julian de Arriaga to Antonio María Bucarely, 22 July 1770, Aranjuez, folio 100, legajo 1134, PC, AGI; Julian de Arriaga to Antonio María Bucarely, 22 August 1769, Madrid, folio 34, legajo 1134, PC, AGI; Julian de Arriaga to Antonio María Bucarely, 22 September 1769, San Ildefonso, folio 56, legajo 1134, PC, AGI; Julian de Arriaga to Antonio María Bucarely, 20 July 1769, Madrid, folio 28, legajo 1134, AGI; Julian de Arriaga to Antonio María Bucarely, 22 May 1770, folio 92, legajo 1134, PC, AGI; Julian de Arriaga to Antonio María Bucarely, San Ildefonso, 22 August 1769, folio 50, legajo 1134, PC, AGI.

480 . Julian de Arriaga to Antonio María Bucarely, 22 February 1770, Madrid, folio 68-69, legajo 1134, PC, AGI; Julian de Arriaga to Antonio María Bucarely, 18 July 1769, Madrid, folio 24, legajo 1134, PC, AGI. 
man who replaced the controversial Marqués de Esquilache after his exile in 1766,

reminded Cuba's captain general,

The matter of chief importance that the King can charge you with is that of maintaining the Factoría de Tabacos in that city [Havana], because that allows the Real Hacienda the ability to have the tobacco that it needs for the provision of this kingdom and those in the Americas, while achieving at the same time that the tobacco workers have the benefit of providing for their families from the prices [paid to them]. ${ }^{481}$

On June 28, 1800, a later minister of finance, Miguel Cayetano Soler, was informed that a Cuban veguero named Manuel Diaz who lived near Güines had petitioned the tobacco monopoly's board for an advance. Citing the "good circumstances with which he [Diaz] had always distinguished himself...," approval was granted to give Diaz the money he requested for the purchase of two slaves to help him with his tobacco crop. ${ }^{482}$

Yet, no one knew the value of Cuban tobacco as an important commodity to the Crown more than the king himself. In the summer of 1769 , when Captain General Bucarely petitioned for additional slaves to work for the monopoly, this request was forwarded to Carlos III (1759-1788). Minister of the Indies Arriaga assured Bucareli] on September 22 of that same year that he had spoken to the king regarding this request, and that the king had given his consent for the purchase of 20 slaves. ${ }^{483}$ Even minute details

481. Kuethe, Cuba, 1753-1815, 77; Miguel de Múzquiz to Marqués de la Torre, Madrid, 21 December 1775, expediente 52, folio 884-886, legajo 1227, PC, AGI.

482 . Luis de Viguri to Miguel Cayetano Soler, 28 June 1800, Havana, legajo 2000, SD, AGI.

483 . Julian de Arriaga to Antonio María Bucarely, 22 September 1769, San Ildefonso, folio 46, legajo 1134, PC, AGI. 
regarding Cuba's tobacco monopoly and its operation were passed along to Spain's

monarch. When don Manuel Ramos de Villavicencio, the man chosen by the vegueros in the Partido de la Canoa to serve as their elected representative (diputado), informed the tobacco monopoly board in early January of 1770 that he was unable to fulfill his duties, Carlos III was also apprised. ${ }^{484}$ The construction of new warehouses, such as the one in the Partido de Mayarí, and the naming of a new warehouse guard along Cuba's southern coast, mentioned above, were all issues that crossed his desk. ${ }^{485}$ These examples clearly demonstrate that the success of Cuba's tobacco monopoly was of such importance that even day-to-day details of its operation were of interest at the highest levels of Spanish governance.

The tobacco monopoly bureaucrats and officials described above, however, did not comprise the full extent of the monopoly's labor force. Enslaved workers on the factory floor, the muleteers who brought tobacco to Havana, and the enforcement branch of the monopoly were essential to the success of the monopoly. In 1753, a list of slaves owned by the Real Compañia de Comercio cites nearly 60 male slaves as working in some capacity for the royal tobacco monopoly. Just over two dozen male slaves between the ages of 18 and 60 labored in the Real Factoría de Tabacos. Nearly all (24 out of 26) were from Africa, with those described as Carabali in the majority (11), followed by

484 . Julian de Arriaga to Antonio María Bucarely, 22 May 1770, Aranajuez, folio 92, legajo 1134, PC, AGI.

485 . Julian de Arriaga to Antonio María Bucarely, 24 May 1771, Aranjuez, legajo 1140, PC, AGI; Julian de Arriaga to Antonio María Bucarely, 24 May 1771, Aranjuez, legajo 1140, PC, AGI 
Congo (6), and Bambara (3). Thirty-two male slaves, all from Africa again with Carabali

(9) predominating, and between the ages of 20 and 68 , worked in the island's tobacco mills. ${ }^{486}$ Yet few other contemporary tallies exist to indicate how many African slaves worked in the tobacco warehouse or in other capacities for the monopoly, although one observer commented that the tobacco factory employed an average of 120 slaves in 1765 , and even more by the end of the monopoly. ${ }^{487}$ A 1791 census from the extramuro barrio of Jesús, María, y José lists 54 royal slaves (esclavos del rey), or nearly one-third of the neighborhood's entire enslaved population, as working in the Real Factoría, while early in the next century, the number totaled nearly 170 slaves, including 42 women who worked as rollers. By 1812, an accounting of the monopoly's assets included 62 slaves in Havana alone. ${ }^{488}$

486. Gabriel Santos, "Lista que comprehende los negros esclavos de R1 Compania de esta Ciudad e Ysla, con destino en el Ramo de Tavacos, y distinction de sus nombres, naziones, Fihaziones, tachas y Edades, los mismos que constant del Ymbentario gral de Existencias del dia treinta y uno de octubre proximo pasado, formando con esta fha a saver," 17 Feb 1753, Havana, Real Factoría de Tavacos, legajo 1002, Ultramar, AGI, photocopy in Archivo General de Indias, AGI, Documentos sobre la Real Compania de Comercio de la Habana, vol. 44, LM, SC, GL, FIU. The breakdown of slaves from the Real Factoría is as follows: Mina 1, Bambara 3, Ganga 2, Congo 6, Carabali 11, Mandinga 1, chino criollo 1, and ingles 1 , while those for the tobacco mills (molinos de tabaco) are: Mina 5, Lucumi 1, Ganga 2, Carabali 9, Bambara 5, Arana 2, Mandinga 4, Sape 1, Congo 1, Lucumi 1, and ingles 1.

487 . Humbolt, The Island of Cuba, 287 cited in Klein, Slavery in the Americas, 159.

488. Capitan del partido de Jesús, María, y José, "Padron general", 30 June 1791, Jesús, María, y José, legajo 1471, PC, AGI; Marrero, Cuba: economía y sociedad, 33; "Noticia del estado de posesiones y enserees de la Factoria de Tabacos de la Habana en fin de December de 812 del num ${ }^{\circ} 4^{\circ}$ de las cuentas del propio año, con expresion de los valores," December 1812, legajo 2001, AGI. 
Along with the other factory employees, slaves were expected to work additional hours beginning at 6 a.m. to noon and from 3 to 6 p.m. three to six when tobacco arrived at the during the periods when tobacco arrived at the Real Factoria, with a regular work schedule of 7 a.m. until noon, and from 3 to 5 p.m. One intendant recommended that the factory slaves should say the rosary every night and "avoid friendships between members of the opposite sex" with the objective to avoid $\sin .{ }^{489}$ These slaves not only provided a valuable labor force to the monopoly, but on at least one occasion prevented considerable economic loss to the Crown. On February 10,1811, shortly after prayers, a fire broke out in the carpentry shop of Havana's Real Factoria de Tabacos building. Slaves from the Real Factoria and the nearby workers' neighborhood successfully fought the blaze and extinguished it, resulting in little damage to the building or its contents. ${ }^{490}$

Like the monopoly's slaves, those who transported the island's tobacco to the Real Factoria in Havana were a necessary component of the monopoly's labor infrastructure. Monopoly officials relied on the muleteers, or arrieros, to deliver tobacco to the main warehouse in the capital, as well as calling on them to transport the funds needed to pay the vegueros for their crop. Between 1751 and 1755, arriero Pedro Hernández and Lieutenant junior grade don Manuel de Quintana regularly delivered funds to eastern Cuba to pay for the area's tobacco harvest. On April 30, 1751 and again in 1754, Captain

489 . "Instrucciones para el Gobierno del Ramo de Tabacos...," 1796, Madrid, legajo 2002, SD, AGI; Gómez Roubaud, "Ynforme...," 25 January 1819, Valencia, typescript in Archivo General de Indias, Cuba, 1720-1819, vol. 25, pages 398-485, LMC, SC, GL, FIU.

490 . Ignacio Gonzalez to Superintendente Director General Int ${ }^{\circ}$., 11 February 1811, Havana, expediente 12, legajo 973, IGH, ANC. 
General Francisco Cagigal de la Vega informed Santiago de Cuba's governor, Alonso Arcos y Moreno, that Hernández and Quintana would be sent out that day with 40,480 pesos $2 \frac{1}{2}$ reales to be used to purchase the region's tobacco crop for that year. ${ }^{491}$ These would not be the only times that the pair would be asked to deliver money to the local monopoly's coffers. Hernández and Quintana again left on the morning of July 20, 1755 to deliver 36,399 pesos in plata sencilla to Santiago de Cuba, and in Bayamo if needed. ${ }^{492}$ In all during this four year period, Hernández and Quintana were responsible for transporting nearly 140,000 pesos to the local monopoly in Santiago de Cuba. ${ }^{493}$

Like other members of society, arrieros occasionally operated outside of the law and were involved in criminal activities. ${ }^{494}$ A slave assigned to work on Havana's projects, Joseph Antonio Sanchez, was wounded by an arriero named Nicolás who fled the scene leaving behind his load of tobacco. Another arriero, Josef Gonzalez from the

491 . Francisco Cagigal de la Vega to Alonso Arcos y Moreno, 30 April 1751, Havana, order 239, legajo 7, CG, ANC; Francisco Cagigal de la Vega to Alonso Arcos y Moreno, 30 April 1754, Havana, order 207, legajo 7, CG, ANC; Francisco Cagigal de la Vega to Alonso Arcos y Moreno, 30 April 1751, Havana, order 141, legajo 6, CG, ANC.

492. Francisco Cagigal de la Vega to Lorenzo de Madariaga, 20 July 1755, Havana, order 89, legajo 7, CG, ANC; Lorenzo de Madariaga to Francisco Cagigal de la Vega, 10 September 1755, Santiago de Cuba, order 255, legajo 7, CG, ANC.

493. Cagigal de la Vega to Arcos y Moreno, 30 April 1751, Havana, order 239, legajo 7, CG, ANC; Alonso Arcos y Moreno to Francisco Cagigal de la Vega, 7 June 1752, Santiago de Cuba, order 234, legajo 6, CG, ANC; Cagigal de la Vega to Arcos y Moreno, 30 April 1754, Havana, order 207, legajo 7, CG, ANC; Cagigal de la Vega to Arcos y Moreno, 30 April 1754, order 141, legajo 6, CG, ANC; Cagigal de la Vega to Madariaga, 20 July 1755, Havana, legajo 7, CG, C; Madariaga to Cagigal de la Vega, 10 September 1755, Santiago de Cuba, order 255, legajo 7, CG, ANC.

494 . Like others with easy access to tobacco, arrieros were sometimes involved in contraband cases as suspects. See the subsequent chapter on contraband for examples. 
town of Santiago, took pity on the wounded man and brought him to Havana to the royal hospital Nuestra Señora del Pilar. ${ }^{495}$

Unlike slaves or muleteers, the enforcement branch of the monopoly, or resguardo, was far from invisible in the contemporary record. Responsible for enforcing monopoly regulations and preventing contraband in tobacco, the resguardo was formed as early as 1764, when Cuba's captain general, the Conde de Ricla, assigned a unit to Regla, located just across the harbor from Havana. The corps was composed of one corporal and three guards assisted by one captain and twelve mounted troops. A much larger horse-mounted troop, the resguardo a caballo, was created on September 28, 1778 and consisted of one primary corporal and five guards. ${ }^{496}$ That first year, salaries for the six resguardo members totaled nearly 3,500 pesos. ${ }^{497}$ The official uniform consisted of a blue jacket with red lapels, blue pants, socks and cape, a white gaucho-style hat. His armament included a wide sword was worn at the waist, a pair of pistols and a rifle. The conspicuous uniform was probably intended as a visual deterrent to crime, but despite

495. Mariano Lacueba, relación, 5 May 1777, Havana, folio 1260, legajo 1153, PC, AGI.

496 . "Informe sobre resguardo de a cavallo por la Administración principal de Renta Reales con comencuencia de auto de Señor Intendente Don José Pablo Valiente, Francisco Antonio de Astigarrota," Havana, 11 July 1787, number 15, legajo 1034, IGH, ANC. A later document cites the original date of the resguardo's founding as October 1, 1778. See José Garcia Alayeto, "Instrucciones para el resguardo montado de la Ciudad de la Havana creado el año de 1778 y reestablicido en este del 1787 en los terminos que en ella se refiere," 15 November 1787, Havana, number 15, legajo 1034, IGH, ANC.

497 . Juan Ignacio de Urriza, "Nomina de los individuos que componen el Resguardo Rentas reales de la Ciudad de la Havana, y su campo, informe al Reglamento aprobado por S.M. con fecha de July de presente año," 28 September 1778, Havana, order 148, legajo 1114, IGH, ANC. 
their intimidating physical appearance, the resguardo did not have an easy task as they patrolled the area, asking those on foot what they were doing and checking suspicious spots for illegal contraband activity. ${ }^{498}$

Two founding members of the mounted tobacco police were don Manuel Pablo Sorrivas, and don Juan Morel. Sorrivas served as first corporal with a salary that year of 730 pesos, an amount that was significantly less than the 2,400 pesos a coronel in Havana's regiment received in 1759 , but more than what a soldier in Havana's garrison earned. ${ }^{499}$ Sorrivas served in that rank as a member of the resguardo until his death in September of 1785 . During his tenure, he was extremely successful in apprehending tobacco contrabanders. In just under a two-week period from late September to early October of 1779 , Sorrivas was personally responsible for capturing at least 122 tercios (approximately 12,200 pounds) of tobacco and returning it to the monopoly.500 Another one of the first guards assigned to the mounted resguardo, Juan Morel served under

498 . "Informe sobre resguardo de a cavallo por la Administración principal de Renta Reales..." legajo 1034, IGH, ANC. The effectiveness of the resguardo and their attempts to rise to the challenge posed by contrabanders is discussed in far greater detail in a subsequent chapter.

499 . de Urriza, "Nomina de los individuos que componene el Resguardo Rentas reales...," 28 September 1778, Havana, order 148, legajo 1114, IGH, ANC; "Informe sobre resguardo de a cavallo por la Administración principal de Renta Reales....," 11 July 1787, Havana, number 15, legajo 1034, ANC; Leví Marrero, Del monopolio hacia la libertad comercial (1701-1763), vol. 8 of Cuba: economía y sociedad (Madrid: Editorial Playor, 1980), 92.

500. "Informe sobre resguardo de a cavallo por la Administración principal de Renta Reales..."11 July 1787, Havana, expediente 15, legajo 1034, IGH, ANC; Juan Ignacio de Urriza to Diego Navarro, 22 September 1779, Havana, legajo 1238, PC, AGI; Juan Ignacio de Urriza, to Diego Navarro, 2 October 1779, legajo 1238, PC, AGI. 
Sorrivas and earned a salary of 547 pesos in 1778 . Like his commanding officer, the fall of 1779 was a successful one for him. Morel recovered 7 tercios of unprocessed tobacco hidden in the Partido de Jesus del Monte home of Tomas Roque on October 25. Several days later, he captured raw tobacco in Havana's Barrio de Jesus María as Ramón de Ochagavia unloaded it. During the night of November 6, Morel seized a horse loaded with 76 manojos (bunches) of tobacco in the Partido de San Juan. ${ }^{501}$

The mid-1780s, however, was a difficult one for the mounted tobacco police. By September 1785 , the resguardo montado was in disarray, and in the fall of 1787 , it was effectively dismantled with all of its members, except one, were in prison on serious charges. Resguardo members Juan Morel, Antonio Bonet, Pedro Galan, and Joaquin Cano were arrested prior to the fall of 1785 as a result of an incident regarding the confiscation of contraband in Guanabacoa. The first three men were all among the first members of the resguardo unit formed in 1778 , while Cano entered the tobacco police force after the death of one of its members. Cuba's intendant proposed don José Miguel, the head of the resguardo a pie mas antiguo, the tobacco police who patrolled on foot, as the new head of the resguardo montado. Miguel was not a good choice for the position, however, argued Raymundo de Onis, the head of the port and Miguel's former supervisor,

501 . Juan Ignacio de Urriza, to Diego Navarro, 26 October 1779, Havana, legajo 1238, PC, AGI; Juan Ignacio de Urriza to Diego Navarro, 29 October 1779, Havana, legajo 1238, PC, AGI; Juan Ignacio Urriza to Diego Navarro, 8 November 1779, Havana, legajo 1238, PC, AGI. Like others in the monopoly's service, Morel fell victim to the lure of illicit activity, and was arrested. Francisco Antonio de Astigarrota, "Informe sobre resguardo de a cavallo...," 11 July 1787, Havana, expedienente 15, legajo 1034, IGH, ANC. For more on this case, and other incidences of illegal activity by monopoly employees, see the subsequent chapter on contraband. 
because he "does not have sharpness, nor the zeal that made him stand out in the Administration of the Port, leaving the post without notice from the intendant..."502

Reinstituted by royal order in March of 1787 , the tobacco police was formally reestablished on November 12 with one corporal as its head, and five guards, all to be stationed in the campo de marte barracks. The only member who had served in the old unit and was not imprisoned, don Gonzalo Blanco Sacido, was made second-incommand. This time, the men chosen to form the new unit were closely scrutinized and chosen for their loyal service to the crown. Two such examples were guards don Manuel de Arza and don Manuel de Miguel y Pérez, who had participated in the disastrous Algiers expedition and successful attack on Pensacola. ${ }^{503}$

Chosen to head the reorganized resguardo montado was don Ramón Bretos. 504 Unfortunately, he suffered from health problems. Despite seeking the services of a bloodletter, by early February of 1800 , Bretos had succumbed. He left a widow, Barbara Almirante, and five minor children, Domingo, Antonio, María Luisa, Francisca, and María de Jesús. An accounting of his assets included houses and a lot located in the

502 . José de Gálvez to José Pablo Valiente, 7 March 1787, El Pardo, number 15, legajo 1034, IGH, ANC.

503 . Francisco Antonio de Astigarreta to José Pablo Valiente, 29 October 1787, Havana, 29 Oct 1787, number 15, legajo 1034, IGH, ANC. See Kuethe, Cuba, 17531815, 94-95, 106-12 for the Algiers and Pensacola expeditions.

504 . de Astigarreta to Valiente, 29 October 1787, Havana, expediente 15, legajo 1034, IGH, ANC. 
Barrio Jesús María. ${ }^{505}$ On February 16, Bretos was buried in the habit of Nuestra Señora

de la Merced, for which his wife paid 16 pesos. The service was held in the parish church of Santo Ángel del Custodio, located in the city's northwestern corner, at a cost of 248 pesos. ${ }^{506}$

\section{The Operation of the Tobacco Monopoly}

The bureaucracy mentioned in detail above was responsible for the operations of the Cuban tobacco monopoly which controlled all aspects of tobacco production, from designating the areas permitted to cultivate tobacco to setting the prices paid for delivered tobacco. Unlike other areas of the kingdom, tobacco cultivation was permitted throughout the island. ${ }^{507}$ The amount produced was regulated, by the crown and tobacco

505 . Fray Rogerio Navarro, Receipt, Convento de Nuestra Señora de la Merced, to Barbara Almirante, 15 February 1800, Havana, expediente 2, legajo 898, IGH, ANC; "Cuenta y relacion firmada que yo Doña Barbara Almirante, como viuda y albacea terredora de bienes de los que quedaron por fallecimiento del Tte de Guarda Mayr Don Ramon Bretos he formado de los que han enterado en mi poder, y corrcerbo a disposición del Señor Intendente General de Exercito y Real Hacienda Juez de su testa y es como sigue," 4 August 1800, Havana, expediente 2, legajo 898, IGH, ANC; Licenciado Francisco Enziaro de Abreau, Account, Barbara Almirante, 3 February 1801, expediente 2, legajo 898, IGH, ANC.

506 . "Memoria de entierro de Don Ramón Bretos hecho en la Iglesia Auxro de Santo Angel Custodio en 16 de February de 1800," expediente 2, legajo 898, IGH, ANC.

507 . The areas in which tobacco could be planted were strictly controlled in Mexico and Colombia for example. Although "the King indicated that he intended to abolish all planting in the colony...his 'royal clemency' inclined him to permit growing in the jurisdictions of Cordoba, Orizaba, and Teusitlan" in the modern-day state of Veracruz. McWaters, "Royal Tobacco Monopoly in Bourbon Mexico," 32. The first two locations were chosen in part because the mountainous geography of the area allowed for easy guarding of the crop, and therefore less possibility of contraband. Despite the order limiting tobacco-growing to only three areas, Jalapa was added by the junta on September 
monopoly officials who determined whether new land could be opened for tobacco

cultivation. Spanish authorities took action, however, when production skyrocketed between 1772 and 1774 to the point that 765,266 arrobas of tobacco, more than the previous five years' total combined, entered the monopoly. 508 By 1774 , the tobacco factory in Seville possessed a surplus of tobacco, and it was determined that an attempt should be made to slow production, while maintaining the current number of vegas and ensuring that a quality product was delivered. Vegueros across the island in 1775 and 1776 were prohibited from creating new vegas. ${ }^{509}$ It worked, perhaps too successfully. It would be fourteen years until Cuban tobacco production would again meet or exceed the

4,1765 in part due to pleas from the alcalde mayor and local merchants who argued that tobacco had been planted there "from time immemorial" "and because it was the area's only significant agricultural crop. By 1769 , however, reports of contraband outside Cordoba convinced the director of Mexico's tobacco monopoly of the need to limit the growing area. McWaters, "Royal Tobacco Monopoly in Bourbon Mexico," 61-62, 71-73. After Colombia's tobacco monoply was reorganized in 1778, tobacco-growing was restricted to "four small and relatively compact areas that were easy to police." Harrison, "The Evolution of the Colombian Tobacco Trade, to 1875," 165.

508. Manuel Ramires de Arellano, "Estado que manifiesta los Tabacos que han entregado los Labradores de este fruto en la Factor general de la Havana y Subalternas de la Ysla desde el año de 61 en que establecío el Ramo por cuenta de la Real Hacienda hasta fin del 18034 August 1804," Habana, table 9, signatura 9454, legajo 209, RC, ANC.

509. Marqués de la Torre to Martín de Azanza, 23 September 1774, Havana, legajo 1179, PC, AGI. A sampling of prohibitions against increasing the number of vegas includes Antonio Fernández to Marqués de la Torre, letter, 21 April 1775, Filipinas, legajo 1180, PC, AGI; Joaquin de Sola to Marqués de la Torre, 2 August 1775, Puerto Principe, document 83, legajo 1173, PC, AGI; Marqués de la Torre to don Juan Mancebo y Castañeda, 23 July 1776, Havana, legajo 1179, PC, AGI. Farmers in one area were instructed that they could keep the tobacco plants already in the ground. Marqués de la Torre to Ambrosio Pérez Baes, 12 May 1775, Havana, legajo 1193, AGI. 
levels achieved in the early 1770 s. ${ }^{510}$ Climate played a large role in the decline of tobacco production during this period, as the years from the mid-1770s through the end of the 1780 s and even through the close of the century were years of intense hurricane activity. No fewer than nine storms impacted Cuba from 1775 to 1789 including a rare winter squall in February of 1781. The situation would little improve as the 1790s brought year upon year of drought, sometimes followed by more hurricanes. ${ }^{511}$

Faced with declining tobacco production, the monopoly could also use its power to promote tobacco, as it did in 1784 when tobacco growers in the Partido de Batabanó were specifically encouraged to increase the number of vegas in the area. ${ }^{512}$ This was not the only location where the crown made a concerted effort to promote tobacco, even during a time argued in the current historiography in which sugar began to dominate the area surrounding Havana. Nowhere is this best demonstrated that in the nearby town of Güines. From a small population center in the late 1750s of just 40 houses surrounding the modest church of San Julián, the village's patron saint, Güines grew into a town devoted to the cultivation of tobacco. During the 1770 s, tobacco production in the area exploded, with the number of farms increasing in a two-year-period alone by 111 from 168 to 279 . By mid-decade, the majority ( 87 percent) of the district's population of 2,340 people lived on the area's vegas, which occupied fully one-fifth of the land mass.

510 . "Estado que manifiesta los Tabacos que han entregado los Labradores...," legajo 209, RC, ANC.

511. Johnson, El Niño's Atlantic World.

512 . José Domingo Morejon to Luis de Unzaga, 26 June 1784, Batabanó, document 97, legajo 1351, PC, AGI. 
In contrast, the partido's three ingenios were home to less than 5 percent of the residents.

Although it took more than a decade to implement, Güines was reorganized as a center for tobacco cultivation which could supply the monopoly with 20,000 pounds of leaf. 513

These examples fly in the face of existing historiography which argues that the countryside surrounding Havana, particularly Güines, was a sugar enclave even before the end of the eighteenth century. 514

One of the most conspicuous responsibilities of the monopoly, however, was to keep track of tobacco produced and ensure that farmers delivered all tobacco designated for the Real Factoría. To ensure this, local officials relied on tazmias, accounting documents that indicated the number of plants each farmer could grow or how much they had produced. ${ }^{515}$ Gathering the information needed to construct a tazmia was not a job to

513. Marrero, Azúcar, ilustración y concencia (1763-1868) (I), vol. 9 of Cuba: economía y sociedad, 217; Johnson, Social Transformation, 54 . The years in question were 1770 and 1771.

514. Moreno Fraginals, The Sugarmill, 19-20, 22-23; Hugh Thomas, Cuba, or the Pursuit of Freedom, updated (New York: Da Capo Press, 1998), 77.

515 . For what type of information should be contained in a tazmia, see Francisco Cagigal de la Vega to Alonso de Arcos y Moreno, letter, 7 September 1750, Havana, order 157, legajo 5, CG, ANC. Numerous tazmias exist and a sampling includes Agustín Hernandes Pulgaron, "Estado en qe se manifiesta la Fuerza de tabaco qe an Producido los Partidos de Bacuranado Sn Jeronimo y Baxunallaba en la cosecha de este año con exprecion de los Labrads numro de operarios y cuges qe cada uno a hadquirido," 6 April 1770, Guanabacoa, legajo 1090, PC, AGI; Francisco Gama, "Tazmia que llo D Franco Gama doi de los Vegas del Partido de Guines con noticia de los indibiduos que las cultiban, number de cuxes que cada una aconfesado abercoxido ela presente cosecha y la tierra abierta que llene cada vega," 16 June 1776, Gama, Güines, legajo 1195, PC, AGI; José de Aguilar y Blanco, "Tazmia qe manifiesta los Tavacos sembrados en el presente año, por los Labradores de los Partidos de la Jurisdicción de esta Villa a saver," 20 March 1782, Sancti Spiritus, legajo 1313, PC, AGI. The Brazilian tobacco monopoly used a similar method to control its industry. After 1775 , tobacco growers producing for export 
be taken lightly as José Claro found out in 1773. Even though he was responsible for making an inspection (visita) of several partidos, taking a tazmia was not part of his commission, the captain general noted, but Claro was given permission to do so and reminded that the tobacco industry operated under "particular rules."516 The information found on the tazmias was later compared to the tobacco produced and turned into the monopoly. Those who failed to turn in the tobacco designated for the Real Factoría were reported to authorities. 517

Cuban officials insisted that tobacco was to only leave the island under the auspices of the Real Factoría as early as 1749. Viewed as an "absolute prohibition," Captain General Francisco Cagigal de la Vega repeated this order at least seven times over the course of sixteen months. ${ }^{518}$ Following the return of Havana in 1763, Spanish

were required to register with the local town councils in an attempt to identify tobacco and cut down on contraband. The information provided to authorities included the farmer's "name, civil status and residence, the location of the fields, and the method of fertilization." An identification number was then given to the tobacco grower, who was required to mark all tobacco rolls with this number in order to identify the origin of any contraband tobacco. Lugar, "The Portuguese Tobacco Trade and Tobacco Growers of Bahia in the Late Colonial Period," 43-44.

\section{AGI.}

516. Marqués de la Torre to José Claro, Havana, 11 June 1773, legajo 1181, PC,

517. Marqués de la Torre to Martín Xavier de Echeverria, 13 July 1774, Havana, legajo 1156, PC, AGI; Notice, 10 November 1782, Filipinas, document 97, legajo 1317, PC, AGI; Manuel Rodríguez to Juan de Mecolaeta, letter, 18 October 1798, Remedios, number 7, legajo 1003, IGH, ANC.

518. Francisco Cagigal de la Vega to Alonso Arcos y Moreno, 21 August 1750, Havana, order 169, legajo 5, CG, ANC; Francisco Cagigal de la Vega to Alonso Arcos y Moreno, 4 September 1750, Havana, order 167, legajo 5, CG, ANC. The August 1750 letter makes reference to similiar requests made in previous correspondenc dated 20 May, 26 July, 2 and 27 September 1749. 
officials quickly sought to regain control of the tobacco industry. That year an edict required that the vegueros deliver all of their tobacco to the Real Factoria and strictly prohibited the sale of tobacco to any individual or entity outside of the monopoly. The penalty for those who purchased such contraband tobacco was fifty ducados. ${ }^{519}$ This order was repeated by top officials in Spain and disseminated by Cuba's captain general to local officials throughout the island. The frequency of these instructions indieates that the vegueros typically failed to comply with these orders until the monopoly was abolished in 1817.520 If the monopoly was to ensure that the tobacco farmers brought all their crop to market, however, fair payment would be necessary. Unfortunately for government officials, this was often easier said than done, making the ever-present

519 . Julian de Arriaga to Antonio María Bucarely, El Pardo, 24 January 1771, legajo 1156, PC, AGI. Protection of the monopoly's sole rights to the tobacco industy had also been important to the French, just as it was for Spain and England, and anyone selling tobacco outside of the official French monopoly was subject to penalties. By July 1681 , these sentences included three years' banishment and a fine for a second offense, while a third offense sent the guilty party to the pillory followed by permanent banishment. Yet few consequences prevented individuals from circumventing official regulations. Price, France and the Chesapeake, 11-12, 17-19, 124-26. As the chapter on contraband indicates, this would also prove to be the case in Cuba.

520 . Marqués de Casa Cagigal to Antonio María Bucarelly, 15 May 1766, Santiago de Cuba, document 12, legajo 1051, PC, AGI; Andres José Carillo to Antonio María Bucarelly, 27 July 1768, San José de Remedios, legajo 1088, PC, AGI; Julián de Arriaga to Antonio María Bucarelly, 22 September 1770, San Ildefonso, folio 121, legajo 1134, PC, AGI; Julián de Arriaga to Antonio María Bucarelly, 24 January 1771, El Pardo, legajo 1156, PC, AGI; Marqués de la Torre to Alcaldes Ordinarios de la Ciudad de San Carlos de Matanzas, 5 July 1772, Havana, document 6, legajo 1187, PC, AGI; Antonio de la Torre to Marqués de la Torre, 24 September 1774, San Juan de Remedios, document 68, PC 1185, AGI; Manuel Coimbra to Luis de Unzaga, letter, 8 agosoto 1783, Havana, document 1, legajo 1351, PC, AGI; Alexandro Ramirez to Secretario de Estado y del Despachado de Hacienda de España, 10 October 1817, Havana, legajo 2019, SD, AGL 
temptation of contraband all the more alluring to Cuba's tobacco farmers. Official, established prices for tobacco purchased by the monopoly varied based on the leaf quality, yet farmers complained that standardized prices fluctuated for the same quality leaf throughout the island, a charge that was accurate. 521 Another top grade, "largo," paid 35 reales per arroba between 1765 and 1785 in Güines and Xiaraco, and 33 reales per arroba in Matanzas, but only 24 reales per arroba in the eastern part of the island known as Tierra-adentro.522 All seven classes of tobacco purchased by the monopoly in Güines, Xiaraco, and Matanzas in 1803 and the following year received the same prices. This was not the case in the Tierra-adentro where prices remained significantly lower, with "largo" grade tobacco bringing 41 reales per arroba in 1803 and 48 reales per arroba in 1804 for "largo" grade tobacco. 523

521 . Antonio María Bucarely to Sr. Bentura Doral, 31 March 1766, Puerto Principe, legajo 1077, PC, AGI; Antonio María Bucarely to unknown, 17 May 1771, Havana, document 42, legajo 1077, PC, AGI; Notice, 10 November 1782, Filipinas, legajo 1317, PC, AGI. This was also the case in Mexico. When Teusitlan was included in the growing area in 1764, the price for their tobacco was set lower because it was determined that their tobacco was of lower quality.

522 . Manuel Ramirez de Arellano, Real Factoría de Tabacos de la Havana, "Estado que manifiesta los distintos precios á que se ha pagado cada arroba de Tabaco á los Labradores de este fruto, desde el establecímiento del Ramo por cuenta de la Rl. Hacienda el año de 1761 hasta el presente de 1804," 4 August 1804, legajo 209, RC, ANC; Manuel Ramirez de Arellano, "Estado que manifiesta los distintos precios á que se ha pagado cada arroba de Tabaco á los Labradores de este fruto, desde el establecímiento del Ramo por cuenta de la Rl. Hacienda el año de 1761 hasta el presente de 1804," Real Factoría de Tabacos de la Havana, 4 August 1804, legajo 2001, SD, AGI.

523 . The seven classes of tobacco were largo, corto, basura limpia, desecho limpio, desechito, libras, and infuriado. Ramirez de Arellano, "Estado que manifiesta los distintos precios ..." Real Factoría de Tabacos de la Havana, 4 August 1804, legajo 209, RC, ANC; Manuel Ramirez de Arellano, "Estado que manifiesta los distintos precios ..." 
These differences cannot be attributed strictly to the superior quality of one

tobacco as compared to another. In 1802 , the royal tobacco monopoly earned no less than 37 percent and as much as 58 percent net profit on Cuba's tobacco after all costs and expenses were calculated. The highest percentage of profits, 58.20 percent, was from Guane where earnings totaled 66,672 pesos, while the second-largest percentage, 54.625 percent, was from the interior, where prices paid for tobacco were historically low. ${ }^{524}$ This suggests that either the quality of tobacco from the interior was higher than the monopoly-paid prices indicates, or that the monopoly was able to sell lower-grade tobacco on the world market at overinflated prices, resulting in a higher profit margin for the Crown.

Further strife between the government and tobacco farmers resulted from the failure to pay the vegueros on time for a crop delivered as required to the royal monopoly. This was not a one-time occurrence, but one that continued until the very end of the

Real Factoría de Tabacos de la Havana, 4 August 1804, legajo 2001, SD, AGI; "Copia del Estado remitido por el Director General de la Factoría con carta de 14 de July de 1814 ..." no date (after 13 July 1814), legajo 2001, SD, AGI.

524 . The Spanish Crown in 1802 earned 643,032 pesos on tobacco purchased from the Island' vegueros and resold through the monopoly. "Demostración del number de Arrobas de Tabaco vendidos al Publico en el año pasado de 1802: del costo principal y demás gastos hasta su venta: del precio de esta; y de la ganancia que en el globo y liquidamente saca el Rey en cada partido," table, number 12, signatura 9454, legajo 209, RC, ANC; Ramirez de Arellano, "Estado que manifiesta los distintos precios ..." Real Factoría de Tabacos de la Havana, 4 August 1804, legajo 209, RC, ANC; Ramirez de Arellano, "Estado que manifiesta los distintos precios ..." Real Factoría de Tabacos de la Havana, 4 August 1804, legajo 2001, SD, AGI; "Copia del Estado remitido por el Director General de la Factoría con carta de 14 de July de 814 ..." no date (after 1813), legajo 2001, SD, AGI. 
monopoly, particularly for farmers in the eastern part of the island. 525 The monopoly's response to this predicament did little to appease Cuba's tobacco farmers. In 1772, Bayamo's vegueros were simply given papers stating that there was no money to pay them for their crop.526 Payment of vegueros in one part of the island and not the other frustrated local officials who had few answers for angry residents. A local official in Sancti Spiritus in 1775 complained to the captain general that payment for the tobacco crop was behind in his area, unlike other locations throughout the island, and that local vegueros were unhappy about this situation. ${ }^{527}$ It was even suggested that the vegueros should turn in their tobacco crop to the monopoly even if they were not paid. 528 Monopoly and government officials however were not ignorant of the effect that lack of payment had on the vegueros' satisfaction with the estanco and consequently their

525 . Felipe Bellos to Antonio María Bucarely, 24 August 1766, Sancti Spiritus, document 10, legajo 1087, PC, AGI; Manuel del Portillo to Marqués de la Torre, 13 June 1775, Sancti Spiritus, expediente 79, legajo 1185, PC, AGI; Antonio de la Torre to Marqués de la Torre, 15 January 1776, San Juan de los Remedios, legajo 1185, PC, AGI; Vicente Manuel de Cespedes to Diego José Navarro, 4 May 1781, Santiago de Cuba, legajo 1231, PC, AGI; "Informe sobre las disposiciones tomadas con los tabacos," 29 April 1815, legajo 2001, SD, AGI. The Cuban tobacco monopoly was not the only estanco that failed to pay the farmers on time. Cuba's governor in November of 1769 warned the viceroy of New Spain viceroy that there were no funds to pay New Spain's vegueros for the previous harvest. Money to pay the farmers did not arrive until August of 1770. Laura Náter, "El negocio colonial de tabaco en el Imperio Español," Social Science History Institute (Stanford University, 2001), 33.

526. Marqués de la Torre to Lieutenant Governor of Bayamo, José de Albanado, letter, 20 April 1772, Havana, folio 310-311, legajo 1179, PC, AGI.

527. Manuel del Portillo to Marqués de la Torre, letter, 13 June 1775, Sancti Spiritus, document 79, legajo 1185, PC, AGI.

528. Pedro Suarez de Urbina to Intendente del Ramo de Tabaco, 18 October 1813, Santiago de Cuba, legajo 2001, SD, AGI. 
agricultural efforts. In 1805, José María de la Torre was able to encourage the tobacco farmers "with hopes of a better contract and considerations in future ones." 529 Intendant Rafael Gómez Robaud, head of the tobacco monopoly, acknowledged in 1810 that when the monopoly paid the farmers for money owed for previous years' crops it helped to restimulate the tobacco industry. .530

Cuba's tobacco farmers, however, were not without recourse. Not only could they turn to contraband, a fear constantly expressed by government and monopoly officials, but they could turn the tables on the government and refuse to pay required governmental obligations as a way of expressing their displeasure with the monopoly's failure to pay them for their crop. Vegueros in various parts of the island in 1775 and 1776 refused to pay for the construction of a bridge, the paving of Havana's city streets, construction of the Jubajay barracks, and maintenance work on the Rio Hondo barracks. They stated that the Factoría de Tabacos owed them for their crop and they were awaiting payment from the monopoly before complying with public works duties. ${ }^{531}$

The amount of tobacco entering Cuba's tobacco monopoly fluctuated wildly, and periods of increases were often followed by dramatic down swings. During the first few

529 . José María de la Torre to Miguel Cayetano Soler, Havana, 5 February 1805 , legajo 2018, SD, AGI. The quote reads "con esperanzas de mejor trato y consideraciones en los succesvio..."

530. Rafael Gómez Robaud to Francisco de Saavedra, 9 January 1810, Havana, legajo 2001, SD, AGI.

531. Marqués de la Torre to Mateo Echevarria, 11 August 1775, Havana, legajo 1156, PC, AGI; Marqués de la Torre to Mateo Echevarria, 28 October 1775, Havana, legajo 1156, PC, AGI; Marqués de la Torre to Mateo Echevarria, 5 January 1776, Havana, legajo 1156, PC, AGI. 
years after the Spanish regained control of Havana from the British, production remained low, averaging 38,005 arrobas annually. By 1766 , however, the tobacco harvests had increased to over 100,000 arrobas a year and continued on this trend for nearly a decade. Yet, officials were not pleased with the vegueros commitment to the monopoly, lamenting that before the English invasion the vegueros turned in their tobacco to the Real Factoría without problem, but now they did not. Despite these concerns, the crop presented to the estanco rose even higher from 1772 to 1774 , with production averaging 255,088 arrobas each year. From 1775 to 1778 , the yield dropped to the mid-100,000 arroba range, dipped even lower the following year, before rising again in 1780 .

Between 1781 and 1783, Cuba's tobacco crop entering the monopoly averaged approximately 40,000 arrobas annually. The high point of Cuban tobacco production under the monopoly from 1763 to 1803 was in 1788 when production peaked at 341,984 arrobas 11 libras. At no other point during this time did tobacco yields even exceed 297,000 arrobas. After the peak in 1788, generally each year saw less and less tobacco entering the monopoly's warehouses. By 1803 , only 37,085 arrobas of tobacco were collected by Cuba's tobacco monopoly. ${ }^{532}$ Yet, demand for the leaf remained high,

532 . "Estado que manifiesta los Tabacos que han entregado los Labradores...," table number 9, legajo 209, RC, ANC; Testimony, 7 November 1770, legajo 1156, PC, AGI. By comparison, during the year of greatest tobacco production for the Louisiana and Mexican monopolies, also 1788, Louisiana produced in excess of 2 million pounds, or approximately 80,000 arrobas, and Mexico's monopoly brought in a little more than 3.5 million pounds, or about 142,000 arrobas.. Coutts, "Boom and Bust," 306; Deans-Smith, Bureaucrats, Planters, and Workers, 263. 
forcing colonial officials during the last part of the 1790s and first decade of the 1800 s to turn northward to Virginia to supplement their existing supplies. ${ }^{533}$

While meteorological occurrences such as hurricanes, droughts, or storms had the power to impact the island's tobacco crop, and sometimes did, they do not appear to have changed the overall production rates during this period. ${ }^{534}$ The years 1768 to 1778 saw no less than eight hurricanes and two periods of drought, yet tobacco production during this period, as described above, only increased. ${ }^{535}$ Similarly, an increase in the price paid by the monopoly did not have a lasting impact on production. While production did increase in each of the five western partidos near Havana the same year that prices were raised on the highest-grade tobacco, this trend was not sustainable. For the partidos of Guane, Güines, and Govea, in several instances production actually fell in the year following a price increase. ${ }^{536}$ Some of the growth in tobacco production, nevertheless, can be explained by entrance of new tobacco-growing areas on the island and the

533 . Josef Pablo Valiente, letter and testimony, 4 July 1799, Havana, number 72 , legajo 2000, SD, AGI; Pedro Antonio Gamon to Juan José de la Hoz, 24 January 1804, Real Factoría de Tabacos, Havana, number 47, legajo 1060, IGH, ANC; El Interventor General de la Real Factoria de Tabacos de la Habana Dn. Ignacio Gonzalez Cadura, 3 March 1810, legajo 2000, SD, AGI; "Demostración hecha por la Contaduria...tabaco rama Virginia...", 15 November 1810, Havana, legajo 2001, SD, AGI.

534 . See Chapter 2 for the impact of weather on tobacco cultivation and production.

535. Johnson, El Niño's Atlantic World; "Estado que manifiesta los Tabacos que han entregado...," legajo 209, RC, ANC.

536 ."Estado que manifiesta los Tabacos que han entregado los Labradores...," table number 9, legajo 209, RC, ANC. This occurred in 1787 for Güines, and in 1801 for all three partidos. 
expansion of existing ones. Growing no tobacco whatsoever for the monopoly between 1762 and 1765, Matanzas and Puerto Principe both entered the tobacco market in 1766 with Matanzas as the third-highest producer of tobacco in the western part of the island. Tobacco production in Güines and Xiaraco likewise climbed after 1766 with each consistently producing in excess of 12,000 arrobas between 1768 and 1778.537

One hundred years after tobacco was first placed under governmental control, the monopoly ended in 1817. Fernando VII and his predecessors had focused their attention on "the promotion and cultivation of the precious plant of tobacco, so important for the exclusive privilege that nature has given the soil of the island of Cuba to produce the most exquisite quality in the world $[\ldots] . . " 538$ The king now acknowledged that the "[...] privileges given to the factory have been the cause of the decline of tobacco production, which had previously exceeded 600 million arrobas, and which today, according to the most impartial reports, does not reach half that amount [...]." 539 With that, on June 23, 1817, all privileges enjoyed by the royal monopoly ended, and the cultivation and sale of all classes of tobacco were now free. ${ }^{540}$ News of the royal decree reached Cuba in midAugust with a passenger on board a ship that had left Cádiz. With him, he carried a July 3 supplement to the Gaceta de Madrid which included a republication of the decree. It

537 . Ibid.

538 . Fernando VII, "El Rey: Dedicado desde la divina Providencia me ha resituido al trono de mis amados vasallos, formentando la agricultura, el comercio y la industria de mis reinos...," 23 June 1817, Madrid, legajo 2000, SD, AGI.

539 . Tbid.

540 . Ibid. 
was reprinted in the Diario del Goberino de la Habana and the Memorias de la Sociedad Economica by mid-to-late September. ${ }^{541}$ Cuba's long governmental control of one of the island's best known agricultural products had officially come to an end.

\section{Cuba's Estanco: A Comparative Perspective and An Analysis of its Effects}

In evaluating the performance of the Cuban tobacco monopoly it is necessary to define the factors that determine success or failure. If the ability of the monopoly to generate revenue for the Spanish Crown is used as the sole measure of its accomplishments, it can be viewed as an overwhelming success. ${ }^{542}$ In just twenty years, from 1740 to 1760 , the crown saw a 500 to 600 percent return on their investment in Cuba's tobacco monopoly which brought in between 6 and 9 million pesos a year, or "about one-fifth of the entire royal income." 543 The impact of these funds on Spain's ability to govern and protect its strategically located colony cannot be overstated. One historian notes that the profit from tobacco, "large enough to finance the entire Spanish

541 . José Rivero Muñiz, Tabaco: Su historia en Cuba, vol. 2, Desde los inicios de la Segunad Factoría de Tabacos de la Habana hasta mediados del siglo XX (La Habana: Instituto de Historia, 1965), 231-32.

542 . Discussed only briefly here, the economic impact of the tobacco monopoly on Cuba as well as other Spanish colonies is examined in greater detail in a later chapter.

543 . McNeill, Atlantic Empires of France and Spain, 158-61. By comparison, the average annual output of Mexican mines during the early 1720 s was over 10 million pesos. John H. Coatsworth, "The Mexican Mining Industry in the Eighteenth Century," in The Economies of Mexico and Peru During the Late Colonial Period, 1760-1810, edited by Nils Jacobsen and Hans-Jürgen Puhle (Berlin: Colloquium-Verlag, 1986), 28. 
navy, easily met the costs of governing and defending Cuba." 544 From 1763 to 1803, a total of 2,494,120 pesos entered the Real Factoria's coffers, representing the value of unprocessed and ground tobacco sold for public consumption. ${ }^{545}$ Monies from royal tobacco monopolies elsewhere in the Spanish Empire occasionally were used to pay for needed local projects. The governor of the Philippine Islands, which also grew tobacco, Rafael María de Aguilar, for example, used funds from its own tobacco monopoly to pay for increased defense costs of the Philippines in 1795 and 1796.546

Yet not all European-sponsored tobacco monopolies met with such success. This was the case in Louisiana where, despite their best efforts both France and Spain abandoned tobacco production under a monopoly. From the beginning, France was uncertain about tobacco's viability in Louisiana as a successful agricultural commodity. Its cultivation was possible, but there were other significant players in the tobacco market, specifically Cuba and Virginia, where tobacco had a greater economic potential. By September 5, 1730, the area's tobacco prospects seemed doomed, as the monopoly was required to buy Louisiana tobacco at the same price paid for Virginia tobacco. "In practice such terms would have meant the total extinction of tobacco cultivation for export along the Mississippi: transportation costs were so much higher from Louisiana

544. McNeill, Atlantic Empires of France and Spain, 158.

545. Manuel Ramírez de Arellano, "Estado que manifiesta el caudal que ha ingresado en Factoría, por valor de los Tabacos rama y polvo, vendidos para consumo publico, desde el establicimiento del Ramo, pr cuenta de la Rl Hacienda, el año de 1761 hasta fin de 1803," 4 August 1804, Real Factoría de Tabacos, Havana, signatura 9454, table number 11, legajo 209, RC, ANC.

546 . de Jesus, The Tobacco Monopoly in the Philippines, 85. 
than from Virginia that little would have been left for the planters." 547 Louisiana's tobacco industry by the early 1760 s still produced only enough tobacco to fill one ship per year, no more than it had in 1731 . With the cession of the territory to Spain and Great Britain in 1762 and 1763 respectively, France's hopes for tobacco cultivation in Louisiana ended. Instead, France shifted its plan for an overseas tobacco source in the New World to its Caribbean island holdings, Martinique and Guadeloupe, but they too were soon abandoned as it proved impractical..$^{548}$

The Spanish experiment with tobacco in Louisiana met with mixed results. It began in the fall of 1770 when Louisiana's governor was ordered to ship all available tobacco to the newly-created tobacco monopoly in New Spain. Tobacco production did not really expand until the early 1780 s, when Spain sent Intendant Martín Navarro to promote tobacco in the region. 549 "By 1782 Navarro had become convinced that tobacco offered perhaps the greatest hope for the future development of the colony." 550 Production expanded so rapidly during the rest of the decade that by 1789 , importation of Louisiana tobacco stopped until the king could be consulted. Shipments of tobacco from Louisiana ended altogether on January 1,1792, a result of overproduction that left a surplus of more than 3.7 million pounds of Louisiana tobacco in Seville's storehouses, poor packing and shipping practices that displeased the crown, and dissatisfied Spanish

547 . Price, France and the Chesapeake, 303, 328.

548 . Ibid., 357-59.

549 . Coutts, "Boom and Bust," 289-91.

550 . Ibid., 292. 
and Mexican consumers. For Louisiana's planters, this spelled the end of their participation in tobacco cultivation. Those who had purchased slaves to open new tobacco land were bankrupted, leaving many New Orleans merchants who had loaned the planters money unable to collect on the loans. Even though the crown sought tobacco again from Louisiana in 1795, not enough tobacco was available, and by the turn of the century most planters now grew cotton. .51

Cuba's tobacco monopoly necessitated the creation of a new colonial bureaucracy, described in detail above, and the expansion of duties for offices already in existence as noted in detail above. As a functionary of the crown, the captain general of Cuba was expected to execute all orders from Spain, and the tobacco monopoly was simply another one of his responsibilities. Yet for those holding the office of tentiente de gobernador, tobacco was one of his primary concerns. Charged with developing the tobacco industry as much as possible, the teniente de gobernador had to send the captain general a copy of the license for all tobacco shipped to Havana. ${ }^{552}$ While Cuban officials were responsible for day-to-day enforcement and the operation of the tobacco monopoly, royal officials in Spain all the way up to the king himself remained aware of minute details regarding the implementation and execution of the royal tobacco monopoly's regulations, successes, and struggles. Prevention of contraband was an important concern for Spanish officials so much so that correspondence between the Minister of the Indies José de Gálvez and Havana from 1787 reveals that Spain was interested in who would fill a vacancy within

551. Tbid., 295-309; Price, France and the Chesapeake, 79, 81.

552 . Corbitt, "The Colonial Government of Cuba," 65-66. 
the resguardo unit caused by the death of one of its members, Manuel Pablo Sorrivas. ${ }^{553}$ Even the details of the resguardo's operations interested Spanish officials. The governor of Havana related to Gálvez in a classified letter the year before that the resguardo had instruction to alternate its patrols between the coast and areas outside Havana's walls (extramuros). The governor also stated that there were ten officers with "good salaries of 20 to 30 pesos a month." 554 Quality control was another area which deeply concerned Spain. In an 1803 royal order, the king acknowledged that there had been "noticeable decline in the plantations of tobacco of the island of Cuba," and that the ground tobacco coming from Cuba was of "bad quality" even after a previous royal order in 1796.555 To remedy this situation and to increase the cultivation of tobacco, and preserve its excellent quality, he named Rafael Gómez Robaud as sole director of the Real Factoría de Tabacos in Cuba. ${ }^{556}$

While the monopoly certainly experienced their share of problems with the island's vegueros, when Spain sought to improve tobacco cultivation in Peru, it recruited Cuban tobacco farmers to serve as instructors. On June 28, 1811, a Spanish official wrote to the head of Cuba's tobacco monopoly requesting that four vegueros be sent to

553 . José de Galvez to José Pablo Valiente, 7 March 1787, El Pardo, number 15, legajo 1034, IGH, ANC.

554 . Governor of Havana to Marqués de Sonora, José de Gálvez, 17 November 1786 , carta reservada number 12 , signatura 15 , legajo 1034 , IGH, ANC.

555 . Royal order, 7 November 1803, San Lorenzo, expediente 12, legajo 96, IGH, ANC.

556 . Ibid. 
Peru with four arrobas of tobacco seed. ${ }^{557}$ That fall, a public notice was published, stating

In the royal order of 28 June of this year, it was communicated to the Superintendent, the temporary director general of the tobacco monopoly of this island, that he was charged, as soon as possible, with sending to Peru four workers of that fruit, under the conditions and pacts agreed upon, that they establish the cultivation in that kingdom, and teach to those natives, the method of this cultivation: the subjects for consideration should have the aptitude necessary for the object indicated, and will present themselves in the Secretary of the Superintendent's office to be accredited, and instructed of the conditions of verification for the job. 558

Spain's royal tobacco monopoly in Cuba appeared to be an all-powerful colonial institution. Having survived a turbulent early start marked by three uprisings, it remained in place for one hundred years. Closer inspection however shows that it was not as successful as initial appearances indicate. Opposition to governmental control of the tobacco industry came in many forms, the most obvious of which were the violent protests of the early days of the monopoly. Other forms of opposition included outright disobedience of the law by growing and selling tobacco on the contraband market, or more subtle means of resistance which could be explained away by the vegueros as accidental. ${ }^{559}$ One of the ways in which the tobacco farmers undermined the monopoly

557. C(illegible) Arguelles to Supintendente general de la Factoria de tavacos de la Havana, 28 June 1811, Cadiz, expediente 22, legajo 973, IGH, ANC.

558 . "Aviso al publico," Juan Antonio de Unzueta, 17 September 1811, Havana, expediente 22, legajo 973, IGH, ANC.

559 . Contraband and other forms of subtle resistance are described in far greater detail in a later chapter. The definitive work on subtle forms of resistance is James C. Scott, Domination and the Arts of Resistance: Hidden Transcripts (New Haven: Yale University Press, 1990). 
was by failing to use care in packing the tobacco for shipment. Wet tobacco not only went against the stipulations of the monopoly contract, but also introduced humidity which damaged the other leaves. Royal officials charged that this type of action was intentional and unacceptable. 560 Spain struggled to overcome many of these challenges, but contraband in tobacco in particular proved an insurmountable obstacle in various locations throughout Spain's overseas colonies. ${ }^{561}$ For Cuba in particular, attempts to enforce compliance with the monopoly's regulations remained a high priority throughout the years examined by this study.

The restrictive nature of the monopoly itself was its own undoing, forming the heart of many of the farmers' complaints. Although the tobacco farmers were guaranteed a buyer for their crop, provided it was of good quality, the farmers had little job or economic security. The large profits garnered by the monopoly even after paying all of its expenses indicates that the vegueros could have easily received higher prices for their crop, while still keeping tobacco a profitable enterprise for the Crown. The monopoly's actions demonstrate that governmental officials viewed the vegueros simply as a labor force rather than suppliers of a specialized product. It was the monopoly, not the experts,

560 . Francisco Cagigal de la Vega to Alonso Arcos y Moreno, 12 February 1754 , Havana, legajo 6, CG, ANC. The letter, in part, reads: "Estos daños provienen de regarse el labrador al reconocimiento de sus tavacos quando le presenta a bender y a más de qual capricho se opone a la razón natural, persuaciva de que el que compra conosca el que se le bende imbiente la intencion explicita de S.M. de que se remita a sus reales fabricas los selecto de pie que tantas vezes se ha advertido [...] la indolencia de los labradores y mercadores de tavacos es de evitar los exportaciones del admicible [...]"

561 . See, for example, Jerry W. Cooney, "La Dirección General de la Real Renta de Tabacos and the Decline of the Royal Tobacco Monopoly in Paraguay, 1779-1800," Colonial Latin American Historical Review 1, no. 1 (Fall 1992): 101-15; Arcila Farias, Historia de un monopolio; de Jesus, The Tobacco Monopoly in the Philippines; Thomas L. Whigham, "Agriculture and the Upper Plata: The Tobacco Trade, 1780-1865," Business History Review 59, no. 4 (Winter 1985): 573-75. 
the vegueros themselves, who determined the number of plants that could be grown, the areas in which tobacco cultivation could be expanded, and on occasion even determined who could or could not grow tobacco. When this labor force felt that their efforts were not rewarded, particularly with monetary compensation, they either sold their product to an appreciative buyer, contrabanders, or simply turned in tobacco with little regard to its packing or other quality controls. Ultimately, the Cuban tobacco monopoly failed to ensure itself as the exclusive buyer for the island's tobacco as it desired, yet it was successful in exemplifying the incredible capacity of the Bourbon Crown to generate revenue and create a new colonial bureaucracy. 


\section{Chapter 6:}

\section{Contraband and the Devil's Weed}

On April 15, 1818, just over six months after Cuba's royal tobacco monopoly was abolished, Braulio de Vivanco, the last man to hold the position of general director, lamented, "The contraband that exists throughout the length of the island has always has been and is very large, and in particular by foreigners; and despite the very rigid orders that have been given for this purpose, they will always be ineffective..." 562 As this chapter will demonstrate, de Vivanco was not exaggerating. Cuba had a long history of participating in contraband, and deterring such illegal exchanges was made even more difficult due, in part, to the vast number of locations along the coast where such illegal exchanges could take place. Preventing contraband in tobacco was even more challenging, as those responsible for administering the island's tobacco monopoly from 1763 to 1817 would learn.

Spain, England, France, and their New World colonies sought to regulate tobacco through the creation of monopolies and thus secure tobacco profits by preventing its sale outside of authorized channels. ${ }^{563}$ Ultimately, however, official Spanish policies were not effective in preventing contraband in New World tobacco since tighter regulations only prompted continued smuggling, to which the state responded with even harsher

562 . Braulio de Vivanco to Señores Directores Generales de Rentas, 15 April 1818, Havana, legajo 2019, SD, AGI.

563 . Europe's tobacco monopolies are discussed in detail in an earlier chapter. 
regulations and controls. Thus, the vicious cycle of regulation, tighter regulations, and increased levels of contraband in tobacco continued unabated. The surreptitious nature of contraband makes the study of such illicit activities difficult to prove or quantify, particularly since the very aim of the smuggler was to elude capture, however, official responses to such illegal trade along with successful seizures of contraband can be used to determine the prevalence of this type of activity. .54

The measures taken by Spain were particularly ineffective in curbing those determined to engage in piracy and privateering on a smaller scale. For these men, the arching string of both large and small islands that separated the Caribbean Sea from the Atlantic Ocean that was the West Indies had long been an area of interest. ${ }^{565}$ Spain

564 . One scholar noted the difficulties in any attempt to study contraband: "The greatest $\sin$ in the smuggler's code has always been the sin of being caught out. A history of smuggling cannot, therefore, be comprehensive. The successful smuggler left few, if any, traces of his illicit activities behind him: he eludes us today as he eluded the collectors of customs in his day, and this history is in a sense Hamlet without the Prince. Yet we do have a wealth of information about his less successful brethren who were brought to book." Neville Williams, Contraband Cargoes: Seven Centuries of Smuggling (Camden, CN: Shoe String Press, 1961), xi-xii. A tiny sampling of works that have addressed contraband include Vera Lee Brown, "The South Sea Company and Contraband Trade," The American Historical Review 31, no. 4 (July 1926): 662-78; Lance R. Grahn, “An Irresoluble Dilemma: Smuggling in New Granada, 1713-1763," in Reform and Insurrection in Bourbon New Granada and Peru, eds. Allan J. Kuethe John R. Fisher, and Anthony McFarlane (Baton Rouge, LA: Louisiana State University Press, 1990), 123-46; Robert C. Nash, "The English and Scottish Tobacco Trade in the 17th and 18th Centuries: Legal and Mlegal Trade,", Economic History Review 35, no. 3 (1982): 354-72.

565 . For contraband in the Caribbean up to the eighteenth century, see Violet Barbour, "Privateers and Pirates of the West Indies," The American Historical Review 16, no. 3 (April 1911): 529-66; Klooster, "Illicit Riches."; I.A. Wright, "The Dutch and Cuba, 1609-1643," The Hispanic American Historical Review 9, no. 4 (November 1921): 597 634; Nuala Zahedieh, "The Merchants of Port Royal, Jamaica, and the Spanish Contraband Trade, 1655-1692," William and Mary Quarterly, 3rd Series 43, no. 4 
attempted to protect their valuable cargo and devised the flota (fleet) system in the midsixteenth century. A convoy of ships left the Central and South American coasts and converged on Havana in the spring where they were outfitted for the long Atlantic crossing in early summer, before the peak of the hurricane season. To protect against privateers or pirates, the flota was accompanied by between two and eight armed galleons and, as a result, the entire fleet was rarely captured. ${ }^{566}$ Nevertheless, from 1585 to 1603 , at least 76 English expeditions intent on seizing Spanish ships headed to the Caribbean,

(October 1986): 570-93. For Caribbean contraband during the eighteenth and nineteenth centuries, see Marina Alfonso Mola, "Corso y flota de Indias: Los convoyes ingleses apresados en 1780 y 1795," in Andalucia, America y el Mar, edited by Bibiano Torres Ramirez, Actas de las IX jornadas de Andalucia y America (Universidad de Santa Maria de la Rabida) (Seville, 1989), 197-270; Celestino Andrés Araúz Monfante, "La acción ilegal de los holandeses en el Caribe y su impacto en las Antillas y Puerto Rico durante la primera mitad del siglo XVIII," Revista/Review Interamericana 14, no. 1-4 (primaverainvierno 1984): 67-79; Allan Christelow, "Contraband Trade Between Jamaica and the Spanish Main, and the Free Port Act of 1766," Hispanic American Historical Review 22, no. 2 (May 1942): 309-43; Héctor R. Feliciano Ramos, "El comercio de contrabando en la costa sur de Puerto Rico 1750-1778," Revista/Review Interamericana 14, no. 1-4 (primavera-invierno 1984): 80-99; Theodore C. Hinckley, "The Decline of Caribbean Smuggling," Journal of Inter-American Studies 5, no. 1 (January 1963): 107-21; George H. Nelson, "Contraband Trade Under the Asiento, 1730-1739," The American Historical Review 51, no. 1 (October 1945): 55-67.

566 . For more on the measures Spain took to protect the fleets, particularly near Cuba, see J.C.M Ogelsby, "Spain's Havana Squadron and the Preservation of Power in the Caribbean, 1740-1748," Hispanic American Historical Review 49, no. 3 (August 1969): 473-88; Carla Rahn Phillips, Six Galleons for the King of Spain: Imperial Defense in the Early Seventeenth Century (Baltimore: Johns Hopkins Press, 1986). The entire Spanish fleet was captured twice by the Dutch, and once by the British. In 1628, Dutchman Piet Heyn seized the whole convoy and its cargo, valued at 15 million guilders, off Matanzas Bay. See J.H. Parry, The Age of Reconnaissance: Discovery, Exploration and Settlement 1450-1650 (Berkeley: University of California Press, 1963; reprint 1981), 181, 188; Robert F. Marx, The Capture of the Treasure Fleet: The Story of Piet Heyn (New York: David McKay and Company, 1977); Francisco M. Mota, Piratas y corsarios en las costas de Cuba (Ciudad de la Habana: Editorial Gente Nueva, c. 1977). 
included two led by Sir Francis Drake. One author even argues that the main purpose behind the failed settlement at Roanoke Island (located in present-day North Carolina) was to create a base from which English ships could attack the Spanish Indies and the treasure fleet. Similarly, the settlements on Jamaica, Curaçao and St. Eustatius were organized in order to take advantage of illegal trade with other European powers' neighboring colonies. ${ }^{567}$

Like the West Indies as a whole, Cuba's numerous ports, cays and inlets "required an army to cover them," Captain General Juan Francisco Güemes de Horcasitas, the future Conde de Revillagigedo, acknowledged in $1741 .{ }^{568}$ Without such resources, the island became a particularly enticing spot for illegal activities. As early as 1513, Spain was forced to use two caravels to patrol Cuba's coastline, but as the island's populated areas expanded, more coastal patrol ships, or guarda costas, were added. Havana, nevertheless, still attracted its share of illicit trade due to its importance as a primary port and the Spanish treasure fleet's last stop before heading out into the Atlantic. The corsair presence was so strong along Havana's coast in 1593 that it forced the incoming

567 . Andrews, The Spanish Caribbean, 156; Kenneth R. Andrews, Elizabethan Privateering: English Privateering During the Spanish War, 1585-1603 (Cambridge: Cambridge University Press, 1964), 191; Jeremy Cohen, "Smuggling in EighteenthCentury Venezuela: The Role of the Práctico," paper presented at Latin American Studies Association (Dallas, TX, 2003), 3.

568 . Governor Juan Francisco Güemes de Horcasitas to the king, 10 December 1741, Havana, legajo 386, SD, AGI, cited in Marrero, Del monopolio hacia la libertad comercial (1701-1763) (II), vol. 7 of Cuba, 118. 
governor, Juan Maldonado, to approach the city via the Old Channel and eventually travel overland from Matanzas. ${ }^{569}$

Most contraband, however, entered through the south, notably by way of Bayamo in eastern Cuba: In 1602, eight of the town's residents who had engaged in smuggling were charged with "rebellion and sentenced to death and confiscation of their property."570 Just over one hundred years later, Bayamo's cabildo (town council) attempted to explain to the Crown why its residents engaged in such illegal activities, arguing that these actions did not represent disloyalty to the King and his royal laws, but rather were prompted by necessity. ${ }^{571}$ Foreign traders remained particularly active in eastern Cuba during the 1740s and 1750s. A letter from September 11, 1747, written to Captain General Francisco Cagigal de la Vega complained that English ships frequented the area around Bayamo and Puerto Príncipe and introduced contraband goods. Ten years afterward, authorities were alerted to the arrival of two ships from Holland and Curaçao intent on engaging in illicit trade along the southern coast. ${ }^{572}$ Although Spanish officials

569 . Barbour, "Privateers and Pirates of the West Indies," 531; Andrews, The Spanish Caribbean, 167; McNeill, Atlantic Empires of France and Spain, 198; Klooster, "Illicit Riches," 72.

570 . Klooster, "Illicit Riches," 72; Louis A. Pérez, Jr., Cuba: Between Reform and Revolution, 2nd ed. (New York: Oxford University Press, 1995), 40.

571 . Klooster, "Illicit Riches," 72.

572 . Unknown to Captain General Francisco Cagigal de la Vega, 11 September 1747, order number 5, legajo 5, CG, AGI; Francisco Ródriguez y Olivera to Lorenzo de Madariaga, 1 September 1757, Bayamo, order number 47, legajo 7, CG, ANC. Other examples of the presence of foreign ships during this period intent on contraband include Francisco Cagigal to unknown, 16 March 1756, Santiago de Cuba, order number 170, 
increased troops or coastal patrols in the areas known to be frequented by contrabanders, not even the threat of the death penalty brought an end to the illegal trade between Cubans and foreigners. .573

For colonial Cuban officials, the problem of contraband appeared nearly insurmountable. During the early eighteenth-century, one governor grimly reported to Madrid that " "there are numbers of ships that pass here with no legal cargo...I work with all my might to eradicate the evil." "574 Authorities on the island acknowledged that the residents did little to assist them in this task. The populace "complain[ed] bitterly", about the cost of maintaining the guarda costas, not because of the expense, but because they interfer[red] with their ability to participate in illegal trade, another governor conceded. ${ }^{575}$ Centuries of participation in illicit commerce, together with the brief period of free trade enjoyed by Havana during the British occupation (1762-1763), resulted in a population that continued to view contraband as a legitimate commercial activity during

legajo 7, CG, ANC; and José Antonio de Quiroga to Lorenzo de Madariaga, 13 December 1757, Juraguacito, order number 17, legajo $7, \mathrm{CG}, \mathrm{ANC}$.

573. McNeill, Atlantic Empires of France and Spain, 184. McNeill notes, however, that the death penalty was rarely enforced. Hubert H.S. Aimes further explains that the contraband trade "centered around Cuban tobacco" and that the "active campaign against the smugglers...led to the war of 1740 between Spain and Great Britain." Aimes, Slavery in Cuba, 22.

574 . Frances Armytage, The Free Port System in the British West Indies: A Study in Commercial Policy, 1766-1822 (London: Longmans, Green, and Co., 1953), 20.

575 . Ibid, 20-21. 
the period examined by this study. ${ }^{576}$ Abundant official correspondence, particularly numerous from the 1760 s to 1780 s, demonstrates the continued presence of and problems associated with contraband in Cuba. While the English were frequently cited, nationals of various countries including France and Holland also were accused by Cuban bureaucrats of engaging in illegal commerce..$^{577}$

\section{The Right Product at the Right Place}

Certain products, particularly any commodity under governmental control, garnered special interest from local and foreign contrabanders alike. Of all the goods available to smugglers throughout Spanish America, tobacco proved to be one of the most popular. 578 "Tobacco has been one of the chief factors causing these coasts to be so much frequented by pirates, by reason of the great demand there has always been for it,"”

576 . Renound Cuban historian Louis A. Pérez, Jr. notes that during this tenmonth period "an estimated 10,000 slaves were introduced to Havana--as many slaves as would have normally entered in ten years." Pérez, Cuba: Between Reform and Revolution, 58. For more on contraband in Cuba, see McNeill, Atlantic Empires of France and Spain.

577 . Araúz Monfante, "La acción ilegal de los holandeses en el Caribe," 73-74. See, for example, legajos 1051,1078-1079, and 1463A-B, PC, AGI; and legajos 1131, 1134-1136, and 1138-1139, SD, AGI.

578 . For a small sampling of works which demonstrate the depth and breadth of the contraband tobacco trade, see Cooney, "Boom and Bust,"; de Jesus, The Tobacco Monopoly in the Philippines; Joyce Lorimer, "The English Contraband Tobacco Trade in Trinidad and Guiana, 1590-1617," in The Westward Enterprise: English Activities in Ireland, the Atlantic, and America 1480-1650, edited by K.R. Andrews, N.P Canny, and P.E.H. Hair (Liverpool: Liverpool University Press, 1978), 124-50; MacInnes, The Early English Tobacco Trade; Arthur Pierce Middleton, "The Chesapeake Convoy System, 1662-1763," William and Mary Quarterly 3rd ser.3, no. 2 (April 1946): 182-207; Whigham, "Agriculture and the Upper Plata.". 
a governor in Caracas complained to the Spanish Crown in 1607, while later in the century, Santiago de Cuba's bishop noted that pirates "infested" the northern and southern coasts of Cuba and carried off harvested tobacco, "the good they most esteem." 579 Spanish officials, though, were not the only ones who struggled to control the tobacco trade within their borders, yet met with little success. As was the case in Cuba, remote or less policed areas such as the Isle of Man located in the Irish Sea were natural centers for illegal trade in tobacco. The tiny European island's free ports provided an easy way during the seventeenth and eighteenth centuries for smugglers to elude customs, and, from there, ship tobacco illegally to nearby England, Scotland, or Ireland. So much of England's early tobacco arrived through illicit means that by 1620 , tobacco imports were required to bear a government seal. Portuguese officials similarly were concerned about the traffic in contraband tobacco throughout their colonies as well as at home where tobacco was sold openly "at prices lower than those set by the crown." 580 Cuban tobacco was particularly prized worldwide, and given the island's long history with smuggling, it is not surprising that when faced with a monopoly on their

579 . Andrews, The Spanish Caribbean, 227; Marrero, Cuba: Economía y sociedad, 54.

580 . Williams, Contraband Cargoes, 9, 124; B.W.E. Alford, W.D. \& H.O. Wills and the Development of the U.K. Tobacco Industry, 1786-1965 (London: Methuen and Company, 1973), 5; MacInnes, The Early English Tobacco Trade, 34, 53, 150; Hanson, "Monopoly and Contraband in the Portuguese Tobacco Trade, 1624-1702," 154. The problem of smuggling remains pertinent even in modern society. For example, smuggled consumer products into Poland in 1993 were estimated to be 20 percent that of legal imports, and Chinese customs authorities claimed confiscations of $\$ 450$ million in 1994 alone. See Kate Gillespie and J. Brad McBride, "Smuggling in Emerging Markets: Global Implications," The Columbia Journal of World Business 31 (Winter 1996): 40-54. 
product tobacco farmers resorted to contraband. Noted scholar of Cuban history, Louis

A. Pérez, Jr. argues that up to 75 percent of the island's total tobacco production was lost to illegal trade, a point further emphasized by the routine presence of Havana leaf on the Dutch market as early as two years after the monopoly was created in 1717.581 Spanish authorities took measures to prevent illegal tobacco planting, smuggling and other fraud, including an active campaign against smugglers, which one scholar argues led to the war of 1740 between Spain and Great Britain. ${ }^{582}$ Meanwhile, the government openly acknowledged at all levels that Cuban tobacco farmers engaged in contraband. Havana regularly issued proclamations known as bandos reminding the farmers that they should deliver all of their tobacco to the monopoly and not sell any of it themselves, a clear indication that officials understood that their inclination was to do otherwise. ${ }^{583}$ Tobacco

581 . José Rivero Muñiz, Tabaco: Su historia en Cuba, vol. 1 (La Habana: Instituto de Historia, 1964), 38; Pérez, Cuba: Between Reform and Revolution, 55; McNeill, Atlantic Empires of France and Spain, 155.

582 . Aimes, Slavery in Cuba, 22.

583 . The ways in which Cuba's tobacco farmers and other attempted to circumvent or negatively affect the official monopoly are discussed in greater detail later in this chapter. For bandos, see, for example, Andres José Carrillo to Antonio María Bucareli, 27 July 1768, San Juan de Remedios, legajo 1088, PC, AGI; Julian de Arriaga to Antonio María Bucareli, 24 January 1771, El Pardo, legajo 1156, PC, AGI; Vicente del Castillo to Antonio María Bucareli, 5 February 1773, El Cano, legajo 1192, PC, AGI; Joaquin de Sola to Marqués de la Torre, 9 July 1775, Puerto Príncipe, document number 87, legajo 1173, PC, AGI; Antonio Daza Maldonado to Superintendente Director General, 25 November 1809, La Habana, number 59, legajo 1060, IGH, ANC. These types of proclamations date back to at least the 1750s. See Francisco Cagigal de la Vega to Alonso Arcos y Moreno, 21 August 1750, Havana, document number 169, legajo 5, CG, ANC; and Francisco Cagagial de la Vega to Alonso Arcos y Moreno, 2 June 1754, Havana, document number 49, legajo 6, CG, ANC. 
monopoly bureaucrats were particularly infuriated by the sale of tobacco from western Cuba's Vuelta Abajo region and complained that the farmers sold "all their tobacco" via illegal channels, leaving only "inferior" tobacco to be presented to the monopoly. 584 Local officials comprehended the importance of preventing contraband. The lieutenant governor of Bayamo, Juan Gemir y Lleonart, who as a young cadet had established himself as a staunch enemy of illegal traders, assured Captain General Antonio Bucareli that he was aware that his diligence in the tobacco harvest was "very important to the service of the king. ${ }^{\prime} 585$ Responding to similar memoranda from Havana, another official, Joaquin de Sola, informed Bucareli that he understood that he was required to fulfill the "commission that he [Bucareli] had consigned regarding the harvest of the tobacco of this partido, and that how, as my duty, I am responsible for any omission that I knowingly make for the completion of said commission." 586 The task set before them was formidable, noted Fernando Muñoz from Trinidad. "I am alone," he complained, making it challenging for him to patrol the vegas to ensure that the farmers had not hidden any tobacco, "and even more difficult in the partidos leeward of this city,

584 . Rafael Gómez Robaud to José de la Torre, 24 October 1894, Havana, legajo 2002, SD, AGI.

585 . Johnson, Social Transformation, 77-78; Juan Gemir y Lleonart to Antonio Bucareli y Ursua, 26 July 1768, Bayamo, legajo 1080, PC, AGI.

586 Joaquin de Sola to Antonio María Bucareli, 28 June 1768, Puerto Príncipe, legajo 1085, PC, AGI. 
that are twenty leagues distant." 587 Muñoz, nevertheless, reassured the captain general, "You can be certain that you have always procured the best from me...because my desire is to fulfill my superiors' orders..." 588

Underscoring the importance placed by Madrid and Havana on preventing the unauthorized sale of tobacco, successes were eagerly noted by the highest branches of Spanish colonial bureaucracy. Three separate sessions of the Council of the Indies, the division responsible for imperial administration, during the months of February and March of 1753 were devoted to recent achievements, notably the seizure of tobacco. On February 17, the council celebrated the previous year's capture by Captain Bernardo Lorenzo Hernández of nearly 200 pouches of ground tobacco, destined for the illegal trade, aboard the schooner San José y las Animas at the port of Banes, six leagues from Havana. March's council sessions were even more encouraging, during which two more attempted cases of contraband were presented. Another vessel also named the San José $y$ las Animas, this time a small schooner under the command of Marcos Ferman, was also captured in 1752 . The ship, owned by a man identified only as "Domingo" from France, was headed toward Trinidad and had intended to take its cargo to foreign colonies, but Cuban authorities recovered a total of 45 sacks of tobacco along the beaches of the Río de la Chorrera. By the end of the month, the council recorded an even larger seizure of 210 pouches of tobacco, discovered by Captain Tiburcio Crespo in the Puerto de la Ortigosa,

587 . Fernando Muñoz to Antonio María Bucareli, 25 July 1768, Trinidad, legajo 1088, PC, AGI.

588 . Ibid. 
a location not usually used for commerce. The site was difficult to reach by land, leading officials to conclude that it was likely that the tobacco was brought there by sea.589 Just three Council of the Indies sessions were dedicated to the topic of contraband Cuban tobacco over the next decade, yet there is no evidence that illicit trade had slowed. .590

In the coming years, officials in Cuba and Spain reiterated to their superiors that tobacco continued to be traded by individuals outside of the official monopoly's confines, despite numerous orders that such activity was strictly forbidden. Not even an edict dating from 1763 that charged fines of 50 ducados for those who hid and sold tobacco deterred contrabanders. By the early 1770 s, the situation on the island was so severe that Minister of the Indies, Julián de Arriaga, felt obliged to remind Cuba's captain general of the standing order. ${ }^{591}$ Three seizures during the early 1770 s demonstrate the volume of this unlawful trade. A November 1772 raid on one home produced ten tercios (approximately 1,000 pounds) of tobacco still on its stalks, while another just fifteen months later led to the confiscation of eighteen tercios of Vuelta Abajo tobacco found at

589 . Consejo de Yndias, 17 February 1753, Madrid, legajo 1131, SD, AGI; Consejo de Yndias, 13 March 1753, Madrid, legajo 1131, SD, AGI; Consejo de Yndias, 24 March 1753, Madrid, legajo 1131, SD, AGI.

590 . Consejo de las Yndias, 22 October 1767, Madrid, legajo 1135, AGI; Consejo de las Yndias, 13 November 1767, Madrid, legajo 1135, SD, AGI; Consejo de las Yndias, 19 July 1769, legajo 1136, SD, AGI.

591 Julián de Arriaga to Antonio Bucareli, 24 January 1771, El Pardo, legajo 1134, PC, AGI; Julián de Arriaga to Antonio Bucareli, 24 January 1771, El Pardo, legajo 1156, PC, AGI. In the case of Antonio Alfonso, discussed in the text below, it was suggested that the fine be raised to 100 ducados. See Marqués de la Torre to Nicolás José Rapun, 16 February 1774, Havana, folio 584, document 530, legajo 1154, PC, AGI. 
Antonio Alfonso's estancia in Cruz de la Padre. ${ }^{592}$ The following year, a local official in

Guanabacoa alerted the Intendant General of the Army that there were "various houses in that town" suspected of harboring illicit commerce. After further inspection, eleven tercios of tobacco were found in Juan González's residence. ${ }^{593}$ In all, these three incidents, among many, resulted in the recapture of nearly 4,000 pounds of contraband tobacco, or slightly more than one-third of the Guane district's entire production in 1772.594 Unfortunately, even seizures such as this did little to stem the flow of tobacco to sources outside of the monopoly.

Spanish and Cuban officials, however, remained undeterred and continued to battle the illegal trade with any means available. One such method meant to dissuade

592 . Marqués de la Torre to Miguel de Altarriva, 256 November 1772, Havana, folio 223, document 266, legajo 1154, PC, AGI; Marqués de la Torre to Martín Xavier de Echevarria, 16 February 1774, Havana, legajo 1156, PC, AGI; Marqués de la Torre to Nicolás José Rapun, 16 February 1774, Havana, folio 584, document 530, legajo 1154, PC, AGI; Marqués de la Torre to Nicolás Rapun, 6 April 1774, Havana, folio 613, document 553, legajo 1154, PC, AGI. By April, it had been determined that the tobacco seized from Alfonso's estancia belonged to Miguel Hernández.

593 . Marqués de la Torre to Martín Xavier Echeverria, 7 February 1775, Havana, legajo 1156, PC, AGI.

594 . For other seizures during the early 1770 s, see Adrian José de Armas to Marqués de la Torre, 5 October 1774, Horcón, folio 23, legajo 1194, PC, AGI; Pablo Gutierrez Muxica to Marqués de la Torre, 15 October 1774, San Juan de Remedios, document 50, legajo 1185, PC, AGI; Marqués de la Torre to Martín Echevarria, 22 Febuary 1776, legajo 1156, PC, AGI. For tobacco production statistics, see Manuel Ramirez de Arellano, "Estado que manifiesta los Tabacos que han entregado los Labradores...," 4 August 1804, Havana, table number 9, signature 9454, legajo 209, RC, ANC. Admittedly, tobacco production for the Guane district was low this particular year, at only 442 arrobas, 4 pounds (or about 11,054 pounds), followed by a ten-year (17651775) high of 4,480 arrobas, 19 pounds (or approximately 112,019 pounds) in 1773. 
others from taking similar actions was dealing harshly with smugglers. A case representative of this paradigm was the seizure of tins of ground tobacco and cigars illegally carried aboard a mail ship ready to set sail for Veracruz in 1769. The captain, don José Aedo, and pilot, José Antonio Vrisote, were taken to Havana's Castillo de la Real Fuerza, stripped of their respective jobs for life and forbidden to work for the king in similar employment.595 A frequent penalty for those charged with fraud or contraband in tobacco was forced military service as Alejandro Mora and Lorenzo Cendra learned, sentenced to serve their time in Puerto Rico, and with the batallion fijo (fixed batallion) in Santo Domingo, respectively. ${ }^{596}$ Some local Cuban administrators offered their own suggestions as how the illegal trade might be prevented, such as Juan Gutierrez's proposal that a "faithful man" be used to escort ships carrying tobacco until the vessel reached deep water twelve leagues away from the Cuban coast. ${ }^{597}$

Starting in the mid-1770s, the emphasis shifted from compliance with official orders to a more pro-active stance that relied heavily on policing and seizures. The island's citizens were a valuable part of this new initiative, and informants who reported

595 . Consejo de las Yndias, 19 July 1769, legajo 1136, SD, AGI.
596 . Alejandro Mora, procesos, document 68, legajo 7135, GM, AGS; Lorenzo Cendra, processos, destino al Regimiento Fijo del reo Lorenzo Cendra, 1787-1789, document 3, legajo 7149, GM, AGS. Beginning on May 22, 1783, sentances in the Phillipines, where illegal trade in tobacco was particularly acute, were stiffened including subjecting contrabanders to eight years of hard labor in the royal arsenal. de Jesus, The Tobacco Monopoly in the Philippines, 48.

597 . Juan Gutierrez to Antonio María Bucareli, 31 July 1768, document 28, legajo 1088, PC, AGI. 
illicit trade in tobacco were rewarded with one-third of the confiscated tobacco's value. ${ }^{598}$

A particularly visible part of this tactic was the 1778 addition of horse-mounted police units (resguardo montado) to the already-existent enforcement branch of the tobacco monopoly, the resguardo. ${ }^{599}$ The success of the tobacco police in just the first year that the resguardo montado was established suggests that such an approach to contraband was effective. During this period, the number of confiscations rose dramatically, and between mid-September and mid-November of 1779 alone, ten separate raids netted 157 tercios (or about 157,000 pounds) of tobacco returned to the Real Factoria. Two original resguardo montado members, First Corporal don Manuel Pablo Sorrivas and Guard don Juan Morel, accounted for 40 percent of these including Sorrivas' capture of 118 tercios

598 . Marqués de la Torre to Martín Echeverria, 22 February 1776, Havana, legajo 1156, PC, AGI; Diego José Navarro to Juan Ignacio de Urriza, 6 August 1779, Havana, legajo 1238, PC, AGI. There is at least one instance where the informant was rewarded with half of the tobacco's value. See Marqués de la Torre to Martín Echevarria, 17 September 1776, Havana, legajo 1156, PC, AGI. Informants were also rewarded in Mexico. See McWaters, "Royal Tobacco Monopoly in Bourbon Mexico," 37.

599 . Francisco Antonio de Astigarrota, "Informe sobre resguardo de a cavallo por la Administración principal de Renta Reales con comencuencia de auto de Señor Intendente D José Pablo Valiente," 11 July 1787, Havana, document number 15, legajo 1034, IGH, ANC; "José Garcia Alayeto, Instruciones para el resguardo montado de la Ciudad de la Havana creado el año de 1778 y restablicido en este del 1787 en los terminos que en ella se refiere," 15 November 1787, Havana, document number 15 , legajo 1034, IGH, ANC. See Chapter 4 for more details on the creation of the resguardo and resguardo a caballo including a description of their duties and uniforms, as well as short biographies of some of their members. 
of tobacco from four separate homes in the village of Guanabacoa, including one belonging to regidor (town councilman) Agustín Hernández Pulgaron. 600

For many however, the lure of the illegal trade in tobacco remained irresistible.

Cristóbal de Cordova risked criminal action during the mid-1780s by forging the signature of an official in western Cuban as part of an attempt to embezzle tobacco. De Cordova, however, was captured and turned over to the island's provisional captain general, Luis de Unzaga, in Havana. ${ }^{601}$ The circumstances under which tobacco was seized also provides a window to the lengths to which those intent on engaging in this illicit commerce would go to ensure their product would avoid seizure. Residences and farms, as noted above, were just some of the locations where smugglers hid their product, but were far from the most unexpected locations where authorities discovered the plant. During the spring of 1800, guard Bartolome Castellaños recovered 39 tercios of tobacco from a home on a ingenio (sugar plantation) owned by don José Ramos. A more unexpected location was a hen house on a estancia owned by don Ramón Año y Vega,

600 . For tobacco seized, see Juan Ignacio Urriza to Diego José Navarro, 18 September 1779, Havana, legajo 1238, PC, AGI; Juan Urriza to Diego Navarro, 22 September 1779, Havana, legajo 1238, PC, AGI; Juan Urriza to Diego Navarro, 2 October 1779, Havana, legajo 1238, PC, AGI; Juan Urriza to Diego Navarro, 26 October 1779, Havana, legajo 1238, PC, AGI; Juan Urriza to Diego Navarro, 8 November 1779 , Havana, legajo 1238, PC, AGI; Juan Urriza to Diego Navarro, 9 November 1779, Havana, legajo 1238, PC, AGI; Juan Urriza to Diego Navarro, 13 November 1779, Havana, legajo 1238, PC, AGI. For a list of the original resguardo montado members, see Juan Ignacio de Urriza, "Nomina de los individuos que componen el Resguardo Rentas reales de la Ciudad de la Havana, y su campo, informe al Reglamento aprobado por S.M. con fecha de Julio de presente ano," 28 September 1778, Havana, order 148, legajo 1114 , IGH, ANC. 
where the head of the resguardo, don Manuel Trensa, along with two guards, seized 12 tercios of San Juan y Martínez tobacco in September 1816. Although one tercio was noted to be of lower quality, the raid netted contraband valued at 101 pesos, 1 real, all of which Trensa returned to the Real Factoria in two wagons that he personally rented for 1 peso, 4 reales. ${ }^{602}$

Occasionally, those charged with tobacco smuggling in Cuba offered an explanation for their actions. When 39 tercios (approximately 3,900 pounds) of tobacco were recovered from a house located on José Ramos' ingenio, veguero don Miguel Delgado of the Partido de Ursulica acknowledged that the tobacco was his. Delgado maintained, however, that Ramos agreed to keep the tobacco on his sugar plantation while the farmer searched for a muleteer and the funds to pay him to take the product to the Real Factoria. The local tobacco farmers' representative, or diputado, don Simon Valiente could support this claim, Delgado argued. ${ }^{603}$ Another case involved a tobacco farmer from the San Juan y Martínez district, deep in the heart of the tobacco-growing

601 . José de la Torre to Luis de Unzaga, 1 August 1784, Pinar del Río, legajo 1350, PC, AGI.

602 . Bartolome Castellaños to Administrador de la Real Factoría de Tavacos, 12 April 1800, Havana, document 1, legajo 898, IGH, ANC; Manuel Trensa to Superintendente Director General, 26 September 1816, Havana, document 8, legajo 1043, IGH, ANC; José González to Intendente del exercito, 28 September 1816, Havana, document 8, legajo 1043, IGH, ANC; Agustín Alvarez to Rafael Gómez Roboud, 30 September 1816, Havana, document 8, legajo 1043, IGH, ANC.

603 . Castellanos to Administración de la Real Factoría, 12 April 1800, Havana, document number 1, legajo 898, IGH, ANC; Testimonio, Licenciado Juan de Arechaga, 23 April 1800, document number 1, legajo 898, IGH, ANC. 
region of western Cuba. Juan de Acosta was charged by the captain of the district, don Armonio de Puentes, with failing to turn in 25 cujes (sticks) of tobacco from the previous year's crop, but the veguero argued that he had been unable to do so because he was "gravely ill."604 Eventually the complaint was lowered to ten sticks, which de Acosta claimed were for his own use. ${ }^{605}$

\section{When the Good Guys turn Bad}

Not even after the farmers turned in tobacco to the Real Factoria was its safety from contrabanders guaranteed. During the late 1760 s, tobacco was stolen from the mills in eastern Cuba and put on board the brigantine Nuestra Señora del Amparo in an attempted case of contraband. In another case, tobacco was taken from Santiago de Cuba's royal storehouses, or almacenes, to the wharf and sold for less than the official price. ${ }^{606}$ In October of 1768, Captain General Bucareli complained that much of the tobacco carried along the route from the interior to Havana was sold before it even reached the city. By the mid-1770s, little had changed as authorities frequently seized

604 . "Delito oficial contra Juan de Acosta, veguero del partido de San Juan y Martínez sobre averiguar el destino que oio a su cosecha de tabaco el año anterior," 1804, number 26, legajo 1003, IGH, ANC. A "cuje" is defined as a thin wooden pole on which cut tobacco is hung for drying. Similarly, the quantity of tobacco held on one of these poles is also called a "cuje". Perdomo, Léxico tabacalero cubano, 182.

605 . Ibid.

606 . Consejo de Yndias, 22 October 1767, Madrid, legajo 1135, SD, AGI; Mateo de Echevarria y Elguerrua to Diego José Navarro, 27 January 1778, Santiago de Cuba, legajo 1231, PC, AGI. 
tobacco just outside Havana's walls or within the capital itself. Once inside the massive walls, a contrabander could easily elude authorities. With no public lighting system in Havana until 1786 when the large buildings on the Plaza de Armas and street corners were illuminated, night offered the ideal cover for those attempting to bring illegal tobacco into the city. ${ }^{607}$ Just over 1,400 pounds of western Cuba tobacco was recovered in three separate raids during July and August of 1776. The majority, 12 tercios of tobacco from the Govea district, was found in Juan Sanchez's home located on the Calle de la Muralla just inside the walls of the city. The remaining tobacco from the partidos of Govea and Guane was confiscated at the Puerta de la Tierra, one of the five entrances into the fortified capital and located just west of the Calle de la Muralla. 608

Although Bucareli did not specifically cite the arrieros as the culprits in 1768 , the muleteers, like the vegueros themselves, had easy access to tobacco and, if so inclined, could readily turn to illegal trade. Unlike those near high population centers who were usually employed full-time in the transportation sector, arrieros in rural settings were not ensured regular work and were more likely to hold another jobs as well. ${ }^{609}$ For some.

607 . Le Riverend Brusone, La Habana, espacio y vida, 138.

608 . Antonio María Bucareli to unknown, 20 October 1768, Havana, document number 27, legajo 1077, PC, AGI; Manuel García to Marqués de la Torre, 8 July 1776, Havana, legajo 1156, PC, AGI; Martín Echevarria to Marqués de la Torre, 25 August 1776, legajo 1156, PC, AGI; Martín Echevarria to Marqués de la Torre, 31 August 1776, Havana, legajo 1156, PC, AGI.

609 . Clara Elena Suárez Argüello, Camino real y carrera larga: La arriería en la Nueva España durante el siglo XVIII (Mexico City: Centro de Investagiciones y Estudios Superiores en Antropología Social, Ediciones de la Casa Chata, 1997), 71-72, 112. 
muleteers, the proximity to such a valuable commodity was impossible to resist. In early 1772, a local official in San Juan y Santiago noted that several arrieros had failed to deliver their shipments to the Real Factoria. Several years later, the head of the resguardo, Manuel Sorrivas, apprehended muleteer Juan de Cristo on the night of October 3, 1779 with tobacco in the Barrio de San Luis Gonzaga, located outside of Havana's walls. 610

The success of the contraband trade in Cuba ultimately depended on government officials turning a blind eye or participating in it themselves. ${ }^{611}$ Although illegal trade in tobacco was rampant on the island, as authorities openly acknowledged, the ability of resguardo montado members Sorrivas and Morel to secure so many captures raises many questions, not the least of which was the reason for their extraordinary success. While luck, the lure of a reward, or perhaps both may have made the two particularly vigilant, another possible explanation for their remarkable job performance is less noble. Morel's eventual fate suggests that his early accomplishments were a result of his inside knowledge of the island's contraband tobacco trade rather than a devotion to his duties. Prior to September 1785, Morel, along with three other resguardo montado members, took part in a seizure of contraband in Guanabacoa. Their actions during this incident

610 . Esteban Rodríguez del Pino to Marqués de la Torre, 19 January 1772, San Juan y Santiago, legajo 1167, PC, AGI; Juan Urriza to Diego Navarro, 4 October 1779, Havana, legajo 1238, PC, AGI. In Mexico, Indian tributary and muleteer José Esteban was sentanced in 1798 to one and a half years in prison for stealing tobacco while transporting it from Córdoba to Mexico City. Deans-Smith, Bureaucrats, Planters, and Workers, 32.

611 . Lewis, "Anglo-American Entrepreneurs in Havana," 120. 
resulted their being stripped of their posts, and placed in prison where they remained as of July 1787.612

Another founding member of the resguardo montado, Guard don Francisco Serrano similarly fell victim to the lure of contraband. In 1787 , he was implicated on four counts of keeping tobacco that should have been delivered to the monopoly. On October 25, José Francisco Grillo, a 25-year-old resident of Govea, gave sworn testimony before the captain of the partido that Serrano and another individual posing as an informant, burst into his home and, without giving any explanation, seized tobacco that Grillo kept for his own use. Grillo also stated that Serrano demanded four pesos in reales, as well as chocolate and bread. José Hernández Estevez, age 45, likewise testified that Serrano forced his way into his residence, and, under the pretense of confiscating it, took two bundles (manojos) of tobacco. In similar sworn statements, Manuel Pita, age 35, and 38-year-old Salvador Gomez, maintained that Serrano also entered their houses and removed tobacco. ${ }^{613}$

612 . "Informe sobre resguardo de a cavallo [sic] por la Administración principal de Renta Reales con comencuencia de auto de Señor Intendente D José Pablo Valiente, Francisco Antonio de Astigarrota, 11 July 1787, Havana, document number 15, legajo 1034, IGH, ANC.

613 . Ibid.; José Francisco Grillo, José Hernández Estevez, Manuel Pita, Salvador Gómez and Francisco de la Cruz Valiente, Testimony, 25 October 1779, Govea, legajo 1267, PC, AGI. While Serrano's immediate fate is unclear, by 1787, he was no longer a member of the resguardo. Cuba's resguardo was not the only colonial Spanish entity charged with preventing contraband that was suspected of collusion. Susan Deans-Smith notes that Mexican resguardo members were believed to be suspect, "although no documented cases came to light." Deans-Smith, Bureaucrats, Planters, and Workers, 91. 
Members of the resguardo were not the only tobacco monopoly officials in positions of power with direct access to tobacco that were accused of misconduct. Bayamo's local monopoly representative (factor) was charged with fraud, specifically failing to include all of the region's tobacco farmers on the annual tobacco accounting sheets as required. Although the indictment was brought by Lieutenant Governor of Bayamo Antonio Laso de la Vega, as of early 1773 , there was no determination that an actual fraud had occurred. According to another Cuban official, the factor had explained his actions and was reminded that he should be more careful in his duties to ensure that all tobacco harvested was indeed collected. Nevertheless, by mid-spring, don Martín de Asanza was named as the area's new tobacco monopoly representative. ${ }^{614}$

The idea that the island's colonial administrators were directly involved in contraband was not beyond reason. As one scholar noted, "virtually every prominent official in Cuba in the early eighteenth century was accused of complicity in illicit trade, and at least one spent years in prison in Santiago de Cuba for his activities."615 Yet, Cuban officials were among many royal employees in Spanish America engaging in illegal activities involving tobacco. In his study of Costa Rica's tobacco monopoly, Marco Antonio Fallas argues that low pay for the tobacco police prompted them to join the vegueros and engage in contraband, while in Mexico, various tobacco monopoly bureaucrats committed fraud and embezzlement against the estanco there, including one

614. Marqués de la Torre to Señora doña Justina Isabel Laso, 15 May 1773, Havana, legajo 1179, PC, AGI.

615. McNeill, Atlantic Empires of France and Spain, 184. 
case involving 18,000 pesos in cash and 5,000 pesos' worth of manufactured tobacco goods. 616

Some Cuban authorities, however, did distinguish themselves through their attempts to prevent illegal activities, particularly contraband. One such person during the 1770s and 1780s was Juan Ignacio de Urriza. Chosen to replace Intendant General of the Real Hacienda, Nicolás Rapun who died in early March of 1776, Urriza was described as "an acerbic, honest and ambitious official who instinctively knew which laws to enforce in order to gain favor at the Spanish court."617 Similarly adept at proving his worth as a loyal and accomplished bureaucrat, he successfully petitioned that the Marqués de la Torre give the post of capitán del partido additional police powers, and from late August

616. Marco Antonio Fallas, La Factoría de tabacos de Costa Rica (San Jose: Editorial Costa Rica, 1972), 65; Deans-Smith, Bureaucrats, Planters, and Workers, 4749. G. Earl Sanders argues for a more moderate view of these bureaucrats. "It is evident that officials at all levels of government either permitted, or fomented, contraband at one time or another in much of Spanish America. However, it has yet to be seriously proved that corruption was universal or general, or that such corruption was the major deterrent to Spanish counter-contraband." G. Earl Sanders, "Counter-Contraband in Spanish America: Handicaps of the Governors in the Indies," The Americas: A Quarterly Review of Inter-American Cultural History 34, no. 1 (July 1977): 59. Government administrators were not the only respected members of colonial society involved in illegal activities involving contraband. Portuguese monks and nuns in the 1670s not only hid and sold tobacco within the monastery and convent walls, but also processed it into manufactured products. Hanson notes that such involvement by the clergy led Lisbon's tobacco monopoly to claim that "in Oporto there was not a monastery or convent which did not engage in illicit tobacco traffic." Susan Deans-Smith notes that in New Spain, the Bishop of Oaxaca sold contraband tobacco "under protection of ecclesiastical immunity." Hanson, "Monopoly and Contraband in the Portuguese Tobacco Trade, 1624-1702," 15455; Deans-Smith, Bureaucrats, Planters, and Workers, 22.

617 . Marqués de la Torre to Miguel de Muzquiz, 7 March 1776, Havana, legajo 1227, PC, AGI; Lewis, "Anglo-American Entrepreneurs in Havana," 120. Lewis also 
to late November of 1779, Urriza informed Captain General Navarro about contraband tobacco seizures no fewer than 17 times. 618

\section{Undermining the Monopoly through More Subtle Forms of Resistance}

While some farmers sold their tobacco outside of the official monopoly, others responded with more subtle means, such as failing to properly follow monopoly regulations. One such method of resistance involved the vegueros using improper methods of packing of tobacco destined for the Real Factoría de Tabacos. In February of 1754, Captain General Cagigal de la Vega complained to the governor of Santiago de Cuba, Alonso Arcos y Moreno, that much of the tobacco from that area was packed and shipped while wet. Tobacco in such condition was in violation of the official contract and could introduce humidity which might harm the entire shipment. Cagigal de la Vega bluntly accused those involved of "indolence" by knowingly dampening the leaves before selling it to the monopoly. ${ }^{619}$ Such actions which were not only "beyond whim but went against natural reason," Cagigal de la Vega fumed, and clearly were part of an

notes that Urriza was responsible for pursuing the contraband case against Francisco de Miranda.

618 . See, for example, Juan Ignacio de Urriza to Diego José Navarro, 21 August 1779, Havana, legajo 1238, PC, AGI; Juan Urriza to Diego Navarro, 30 September 1779 , Havana, legajo 1238, PC, AGI; Juan Urriza to Diego Navarro, 29 October 1779, legajo 1238, PC, AGI; Juan Urriza to Diego Navarro, 20 November 1779, Havana, legajo 1238, PC, AGI; Johnson, Social Transformation, 81.

619 . Francisco Cagigal de la Vega to Alonso Arcos y Moreno, 12 February 1754, Havana, legajo 6, CG, ANC. 
attempt "to avoid the exportation of admissible" tobacco. ${ }^{620}$ Less than five months later, Cagigal again reminded Arcos y Moreno that the tobacco farmers were expected to turn in seasoned, clean and separated tobacco. As late as 1804, such actions continued to be a problem for the monopoly, with some vegueros deliberately wetting the leaves, which gave them more weight, but also caused them to rot. ${ }^{621}$

Spain was aware that problems existed with shipments from Cuba to other Spanish dominions, particularly New Granada. Frequent complaints during the early 1770 s about Cuba's poorly-packed tobacco indicates that the problem went far higher than just' veguero misconduct. On October 9, 1771, Cuba's Captain General Bucareli informed minister of the Indies, Julián de Arriaga, that the tobacco sent to Cartagena was described by the viceroy in Santa Fé de Bogotá as being of the most inferior quality, yet as late as the summer of 1774 , the problem had not been corrected. Don Santiago de Viana, the tobacco monopoly's administrator in Cartegena, criticized the poor quality of the tobacco he received from Cuba, calling it "bad tobacco, of waste class."622 From Spain, Arriaga

620 . Ibid.

621. Cagigal de la Vega to Arcos y Moreno, 2 June 1754, Havana, document number 49, legajo 6, CG, ANC; José de la Torre to Rafael Gómez Roubaud, 19 October 1804, Havana, legajo 2018, SD, AGI. Illegal tampering with tobacco was not limited to Cuba, however. Such activity was common in the United Kingdom's tobacco industry during the $1830 \mathrm{~s}$ and although authorities were aware of this practice, it was sometimes difficult to determine, particularly when more sophisticated methods such as those involving saccharin-based solutions were virtually impossible to detect without chemical analysis. Alford, W.D. \& H.O. Wills, 76.

622. Antonio Bucareli to Julián de Arriaga, 9 October 1771, Havana, document 79, legajo 1140, PC, AGI; Miguel de Muzquiz to Marqués de la Torre, 24 June 1774, Aranjuez, legajo 1227, PC, AGI. 
reminded Cuba's new captain general, the Marqués de la Torre, that Cuba should send the type of tobacco requested in order for the monopoly to develop as much as possible. ${ }^{623}$

Yet, it was not until Spain itself began to receive poor quality tobacco that harsher language was employed. At first, Minister of Finance Miguel de Múzquiz was reserved, informing de la Torre that 800 pouches of ground tobacco sent on board the brigantine $e l$ Principe to the factory in Seville was of bad quality, as had been previous shipments.

The following month, however, Múzquiz was less restrained,

The greater part of the ground tobacco that has been sold in the past year, 1771, and in the current one of 1772 from the Factoria of that island to the factories in Seville have been declared by the experts of the same factories, and those of the General Store in Madrid, as entirely useless. ${ }^{624}$

Complaints from the finance minister regarding the receipt of poor quality tobacco from the island continued throughout the following spring. For his part, de la Torre attempted to rectify the situation, reminding authorities on the island that no one should accept tobacco unless it fell under the specific guidelines required by the monopoly. ${ }^{625} \mathrm{Mid}-$ July, however, brought additional complaints from Spain, this time directly from Seville. Tobacco that had been shipped to the city from Cuba via the port of Cádiz was damaged.

623. Muzquiz to de la Torre, 24 June 1774, Aranjuez, legajo 1227, PC, AGI.

624 . Miguel de Múzquiz to Marqués de la Torre, 1 September 1772, San Ildefonso, legajo 1227, PC, AGI; Miguel de Múzquiz to Marqués de la Torre, 24 October 1772, San Lorenzo, folio 914-917, legajo 1227, PC, AGI.

625 . Miguel de Múzquiz to Marqués de la Torre, 22 March 1773, folio 791, legajo 1227, PC, AGI; Miguel de Múzquiz to Marqués de la Torre, 22 March 1773, folio 795, legajo 1227, PC, AGI; Marqués de la Torre to Juan José Claro, 11 June 1773, Havana, legajo 1181, PC, AGI. 
During the off loading and transfer process in Cádiz, it was observed that the ships on which tobacco arrived from the island were not properly ventilated to prevent moisture from reaching the tobacco. The problem became so severe that by late December of 1773, the principal administrator of the tobacco monopoly in Cádiz refused to let ships from Cuba unload their cargo. ${ }^{626}$

The problems experienced by Spain with the receipt of tobacco from Cuba's monopoly appear to have been ones related to shipment difficulties, not intentional negligence or attempted fraud. Subsequent complaints, however, point to the possibility that the latter was occurring. On October 8,1773 , de la Torre wrote to Múzquiz that he could not understand why the tobacco shipped from Havana to Seville had decreased in weight by 24,618 pounds while in transit. That same day, an official in Havana tried to reassure de la Torre that the discrepancies were not his fault. Nevertheless, problems with tobacco from Cuba remained, with Madrid still registering complaints with the island's top bureaucrat a year later. The shipments now contained, Múzquiz reported, "strange leaves...and others from tobacco ordered burned" as well as green or uncured tobacco leaves. ${ }^{627}$ Even after so many objections from Spain's finance minister directly

626. Vicente Carraso to Marqués de la Torre, 21 July 1773, Seville, folio 820 , legajo 1227, PC, AGI; Miguel de Múzquiz to Marqués de la Torre, 24 December 1773, Madrid, folio 839-840, legajo 1227, PC, AGI.

627 . Marqués de la Torre to Miguel de Muzquiz, 8 October 1773, Havana; legajo 1227, PC, AGI; Martín Xavier de Echevarria to Marqués de la Torre, 8 October 1773, Havana, folio 1029-1034, legajo 1227, PC, AGI; Miguel de Muzquiz to Marqués de la Torre, 6 September 1774, San Ildefonso, document 43, folio 866-867, legajo 1227, PC, AGI; Miguel de Muzquiz to Marqués de la Torre, 16 September 1774, San Ildefonso, document 45, folio 870-871, legajo 1227, PC, AGI. 
to Cuba's captain general, the quality of tobacco shipped to the Real Fabricas in Seville had not improved, perhaps indicating that not only the vegueros were engaging in fraud. According to regulation, tobacco was inspected at numerous levels and monopoly representatives ordered to deliver only a high-quality product. The continued poor quality of the tobacco shipped, and the large discrepancies between its listed weight when it left Cuba and arrived in Spain suggest that Real Factoria employees in Cuba were deliberately defrauding the government monopoly.

Violent measures such as the destruction of the plants in the fields were less common, but equally damaging. One oft-repeated story describes how a farmer in Güines, José de Coca, burned eleven vegas in 1792 in protest to the Real Factoría's destruction of 58 cargas of poor quality tobacco, the crop for the entire year. ${ }^{628}$ As late as 1805, officials in Cuba noted that some vegueros had abandoned their plants, while others had cut back production. ${ }^{629}$ These ways in which tobacco farmers protested against governmental authority was one employed in other areas as well, often as part of a nascent revolutionary movement against the crown. In Virginia, planters turned to crop destruction on several occasions, first in 1682 and later in 1732, as did those in Mexico

628 . Francisco de Arango y Parreño, Obras del Exmo. Señor D. Francisco Arrango y Parreño, vol. 1 (Habana: Howson y Heinen, 1888), 461, 466; Guerra y Sánchez, Pérez Cabrera, Remos, and Santovenia, Ilustración libertad de comercio (desde 1790 hasta 1837), 9; Moreno Fraginals, El ingenio, 57; Thomas, Cuba, or the Pursuit of Freedom, 77. Despite the prevelance of this story in numerous works, no primary evidence has been found to date in either Spanish or Cuban archives that corroborates this account.

629 . José de la Torre to Miguel Cayetano Soler, 5 February 1805, Havana, legajo 2002, SD, AGI. 
under rebel leader José María Morelos and his followers who burned tobacco fields in the Veracruz province as "part of their military strategy to destroy the Crown's resources." 630

\section{The Lure of the "Devil's Weed"}

Nations throughout Europe placed restrictions on tobacco's production and sale in the hopes of securing tobacco's profits for the state, as well as eliminating any competition from contrabanders. Unfortunately for Spanish officials, tobacco was in great demand, and therefore garnered a high price on the domestic and international markets. Madrid tightened its control on the tobacco industry, hoping to secure profits for the state and attempting to eliminate any competition from contrabanders. Yet, these increased measures only served to fuel illegal activities, prompting tighter controls, and thus, the vicious cycle of restrictions and contraband spun out of control. Tobacco was a valuable commodity, both economically and symbolically. Spain's ability to control and regulate economic activities within its colonies and domestic borders was a sign of the crown's strength and stability. Threats such as those posed by traffickers in contraband tobacco tested the very essence of state control, and potently demonstrated that individuals operating outside of official, legal channels could not only challenge the state, but also successfully defy it.

630 . Aycock, "Tobacco Regulation in Colonial Virginia," 74-82; L.C. Gray, "The Market Surplus Problems of Colonial Tobacco," William and Mary Quarterly 2nd series,12, no. 4 (October 1927): 234; Saloutos, "Efforts at Crop Control in Seventeenth Century America," 62-65; Kulikoff, Tobacco and Slaves, 109-12. The incidents of tobacco farmers destroying their crops are described in greater detail in Chapter 1. For Mexico, see Deans-Smith, Bureaucrats, Planters, and Workers, 99. 
Correspondence between the highest levels of Spanish government and the island, and among officials in Havana and the interior reveal the ongoing concern posed by contraband and other forms of resistance to the monopoly. Throughout the period discussed in this study, authorities sought to eliminate the loss of tobacco to parties outside of the official estanco. These measures included tighter restrictions and controls such as the resguardo, paradoxically however, such actions historically had only fueled Cuba's illicit commerce in tobacco. ${ }^{631}$ Despite its long-standing presence in commercial activities in the Americas and Europe, contraband never gained legal respectability. Instead of being viewed as clever entrepreneurs who were interested in participating in a profitable economic activity, pirates, privateers, and smugglers continued to be viewed as extralegal actors who deserved neither the spoils of their labor nor protection under the law. .32

Faced with harsh sentences and increased measures to inhibit contraband, why was this illegal activity still prevalent during the eighteenth and nineteenth centuries, why would the island's vegueros risk fines, confiscation of their crop, or other punishment? Although the farmers' exact motivations are difficult to establish, archival research points to economic reasons as possible motivating factors for their decision to operate outside of the officially sanctioned monopoly. Compliance rested heavily on the Real Factoria's

631. McNeill, Atlantic Empires of France and Spain, 198.

632 . Marcus Rediker, "'Under the Banner of King Death': The Social World of Anglo-American Pirates, 1716 to 1726," William and Mary Quarterly 3rd series 38, no. 2 (April 1981): 218. Rediker notes that pirates were prohibited access to clergy, "called 
ability to provide the vegueros with a profitable, or at least adequate, alternative to contraband. Prompt payment of the farmers, and establishing competitive official prices for the tobacco harvest were two essential components of this strategy, however, it is in these two areas that the monopoly frequently faltered.

The Real Factoría required Cuba's vegueros to present their tobacco in a timely manner, yet often did not pay them expeditiously, causing some farmers to sell their tobacco through unauthorized channels. This was a particularly acute problem in Sancti Spíritus where as early as August 1766, Bucareli was alerted that fraud and the sale of tobacco to individuals, both prohibited under the official monopoly, had occurred as a result of the monopoly's failure to pay for the tobacco it received. Two years later, the problem remained uncorrected, prompting farmers to sell tobacco to non-monopoly sources due to a "lack of money," Juan Guiterrez informed the captain general. ${ }^{633}$ Even into the next decade, the monopoly remained behind on payments to Sancti Spíritus' tobacco farmers, unlike other areas of the island, even though the monopoly's board had found funds to pay the vegueros, a local official remarked. ${ }^{634}$

Hostis Humani Generis, with whom neither Faith nor Oath' were to be kept, and were regarded as 'Brutes, and Beasts of Prey."”

633 . Felipe Bellos to Antonio Bucareli, 24 August 1766, Sancti Spíritus, doccment 10, legajo 1087, PC, AGI; Juan Gutierrez to Antonio Bucareli, 31 July 1768, Sancti Spíritus, legajo 1088, PC, AGI.

634. Manuel del Portillo to Marqués de la Torre, 13 July 1775, Sancti Spíritus, document 79, legajo 1185, PC, AGI; Manuel del Portillo to Marqués de la Torre, 20 July 1775, Sancti Spíritus, document 82, legajo 1185, PC, AGI. 
At the far eastern end of the island, Holguin's vegueros also complained that they were not paid when they delivered their crop to the monopoly. Correspondence between various regional officials and the captain general in Havana reveals that the problem may have lain not with the estanco, but with its factor. Antonio Luque, the lieutenant governor of Holguín, accused the city's factor of delaying payments to the vegueros and, by the summer of 1774 , had alerted the Marqués de la Torre to the situation. De la Torre responded, "the least he has been able to do is be unhappy with the conduct of that judge, but, obliged to quell the complaints of the labradores (tobacco farmers), he has done it before they were able to further criticize." 635 By September of that year, the case against the factor was still active, and de la Torre had issued a notice to the island's lieutenant governors noting that they were requested to refrain from "the economic and governing management of the Factorias." ${ }^{636}$

For Bayamo's tobacco farmers, lack of payment for their crop was a reoccurring problem. In the spring of 1772 , one of its residents complained that when the vegueros sold their tobacco to the monopoly, they were given documents stating that there was no money to pay them for their crop. A year later, the Marqués de la Torre noted that there were profits available in the Real Factoria and suggested that the area's tobacco growers

635 . Marqués de la Torre to Antonio Luque, 11 August 1774, Havana, legajo 1144, PC, AGI.

636 .Juan Antonio Ayans de Ureta to Pascual de Cisneros and Marqués de la Torre, 4 September 1774, Santiago de Cuba, document 225, legajo 1142, PC, AGI; Marqués de la Torre to Echeverria, 13 August 1774, Havana, legajo 1156, PC, AGI. 
be paid from these funds. Still issues regarding payment of the vegueros continued, and the following summer, de la Torre wrote to the current lieutenant governor of the region,

I obligate you to solicit the permission to find in this area some quantity of money, liberating them against the Treasury of the Tobacco Monopoly of this city, so that the vegueros of that jurisdiction, who only with the product of their crops they can alleviate the miseries that they suffer, are contented in some manner... 637

By that fall, no progress had been made on the issue. ${ }^{638}$ Even into the 1790 s, Bayamo's vegueros were not ensured of prompt payment for their crop. Funds destined for the purchase of the region's tobacco had been delayed as two of the dragoons carrying them had fallen ill, one in Puerto Príncipe and the other in Villa Clara. On October 1, 1793, the area's governor general was informed that the funds had finally arrived. ${ }^{639}$

The decision to turn to contraband as a viable option may have also stemmed from the vegueros' belief that the crown did not adequately compensate them. For some farmers, this may have resulted in severe financial difficulties, while others may have been driven by a desire for maximized profits on their tobacco crop. Officials often cited the farmers' inability to support their family from tobacco production as a chief

637 . Marqués de la Torre to José de Albanado, 20 April 1772, Havana, folio 310311, legajo 1179, PC, AGI; Marqués de la Torre to José de Albanado, 10 November 1773, Havana, folio 386-387, legajo 1179, PC, AGI; Marqués de la Torre to Martín de Azanza, 4 July 1774, Havana, legajo 1179, PC, AGI.

638. Marqués de la Torre to Martín de Azanza, 23 September 1774, Havana, legajo 1179, PC, AGI.

639 . Agustín de Herrera Beloquin to Governor General, 1 October 1793, Bayamo, legajo 1464, PC, AGI. 
motivating factor as to why they turned to the contraband trade. 640 Financial need was so great in some areas that local authorities, especially in Pinar del Río in 1768 and 17801781, petitioned the captain general to give surplus meat to the vegueros to help sustain their families. ${ }^{641}$ If financial incentives for turning to illegal trade been removed through prompt and fair payment by the estanco, enforcement of the order that the vegueros deliver all of their tobacco to the royal warehouses might have been easier, Cuban officials had argued for decades. ${ }^{642}$

While the argument that contraband was an attractive economic option for the poor is not novel, economic need alone is not sufficient to explain the persistence of Cuba's contraband tobacco trade. ${ }^{643}$ As shown in an earlier chapter, an examination of tazmias from across the island during this period indicates that Cuba's vegueros were not restricted one particular socioeconomic group or background, and instead were much more heterogeneous. Small, independent farmers, sharecroppers, slaves, free blacks,

640 . Felipe Bellos to Antonio Bucareli, 24 August 1766, Sancti Spíritus, document 10, legajo 1087, PC, AGI; de la Torre to Albanado, 20 April 1772, Havana, folio 310-311, legajo 1179, PC, AGI; José de Alvaredo to Marqués de la Torre, 14 September 1776, Trinidad, legajo 1176, PC, AGI.

641 . Tomás de la Luz to Marqués de la Torre, 25 May 1768, Pinar del Río, legajo 1093, PC, AGI; Marqués de la Torre to Antonio Fernández, 14 April 1775, legajo 1181, PC, AGI; Ramón Lloret to Diego Navarro, 31 May 1780, Filipina, legajo 1261, PC, AGI; Gabriel de Mier to Diego Navarro, 4 December 1780, Filipinas, legajo 1261, PC, AGI; Gabriel de Mier to Diego Navarro, 9 May 1781, Filipinas, legajo 1317, PC, AGI.

642 . Francisco Cagigal de la Vega to Alonso Arcos y Moreno, 8 May 1752, Havana, order number 155, legajo 6, CG, ANC.

643 . Susan Calafate Boyle, Los Capitalistas: Hispano Merchants and the Santa Fe Trail (Alberquerque: University of New Mexico Press, 1997), 56. 
military officers, priests, gentlemen and titled royalty all participated in the growing of tobacco in Cuba. The presence of gentlemen ("don"), priests, and military officers as vegueros indicates that tobacco was more than just a means of subsistence for small, impoverished farmers. The production and sale of tobacco, either through official channels or via the contraband market, offered the possibility of significant profits, as both individuals and the crown learned. ${ }^{644}$

Archival research reveals that despite the royal tobacco monopoly's apparent rigidity, at least on paper and in traditional studies, Cuba's vegueros exercised significant personal agency in their economic activities. Such illegal activities represented both a financial threat and a potential challenge to state control in eighteenth century Cuba. The prevalence of this extralegal behavior, described in numerous documents, demonstrates the ineffectiveness of Spain's tobacco monopoly on the island, particularly difficult to enforce after the unprecedented openness enjoyed during the ten-month British occupation (1762-1763). The participation, or at least tacit acceptance, of those charged with preventing such illicit trade in tobacco, ensured that the monopoly would fail in its ultimate goal of securing all of the island's best tobacco for its own use. Despite these hurdles, Cuba's tobacco industry proved to be a significant source of income for the crown as well as a vital component of the island's rural infrastructure during the late eighteenth and early nineteenth century.

644 . The diversity of the veguero population, including the presence of individuals of higher social status, is discussed in detail in Chapter 3, while the impact of Cuba's tobacco industry is detailed in Chapter 7. 


\section{Chapter 7:}

\section{Cuban Counterpoint Revisited}

In 1947, Fernando Ortiz wrote, “.... a study of the history of Cuba, both internal and external, is fundamentally a study of the history of sugar and tobacco as the essential bases of its economy." 645 Ortiz demonstrated in his Cuban Counterpoint that these two crops in many ways are locked in an agricultural form of sibling rivalry. Although one is native to the island and the other is a foreign import, at the height of their influence, both employed thousands in their cultivation, harvest, and processing. Each product helped to define and shape Cuba's social structure and economics. Yet, for decades sugar has been the exclusive lens through which many scholars of the island have viewed Cuban history. ${ }^{646} \mathrm{~A}$ focus on sugar to the exclusion of other agricultural pursuits, tobacco in particular, has resulted in an incomplete view of colonial Cuban society and economy. Recent ground breaking studies by both U.S. and Cuban scholars offer a new cutting-edge

645. Ortiz, Cuban Counterpoint, 5.

646 . See, for example, Raúl Cepero Bonilla, Azúcar y abolición (Apuntes para una historia crítica del abolicionismo (La Habana: Editorial Cenit, 1948); Cepero Bonilla, Azúcar y abolición; Raúl Cepero Bonilla, Obras históricas (La Habana: Instituto de Historia, 1963); Guerra y Sánchez, Pérez Cabrera, Remos, and Santovenia, Guerras coloniales conflictos y progresos (desde 1697 hasta 1790); Guerra y Sánchez, Pérez Cabrera, Remos, and Santovenia, Ilustración libertad de comercio (desde 1790 hasta 1837); Manuel Moreno Fraginals, El ingenio; Levi Marrero, Cuba: su economía y sociedad, 15 vols. (Río Piedras, P.R. : Editorial San Juan, 1972); Bergad, Cuban Rural Society in the Nineteenth Century. 
perspective of life in rural colonial Cuba that disputes the primacy of sugar in the late eighteenth and early nineteenth century. ${ }^{647}$

This chapter places the role of tobacco in colonial Cuba in context and argues that tobacco was a far more significant agricultural pursuit than sugar in many areas of the island, especially during the late eighteenth century. Going beyond just the sheer numbers of farms, workers, or production, the economic impact of Cuba's tobacco monopoly was seen in the Spanish crown's outlay of monies for capital assets, bureaucrats' salaries, and payments to vegueros for their crops, not to mention a return on that investment as money into the royal coffers. Tobacco's role in the greater Spanish colonial economy will be placed in broader context to demonstrate that the what happened in Cuba was not an anomaly. Finally, the Cuban tobacco monopoly will be evaluated as a function of the Bourbon Reforms to determine the success or failure of such an undertaking by the crown, as well as determine the degree to which Spain was able to exercise control over the island colony and its residents.

Three themes--slavery, monoculture, and foreign investment--have shaped the historical discussions of sugar and Cuba. ${ }^{648}$ Each are issues deserving academic

647 . Pérez, Winds of Change; Johnson, Social Transformation; Fé Iglesias García, La estructura agrária en el occidente de Cuba, 1700-1750. Manuscript in preparation, in possession of author; William C. Van Norman, Jr., "Shade Grown Slavery: Life on a Coffee Plantation in Western Cuba, 1790-1845," Ph. D. Diss. (Chapel Hill, NC: University of North Carolina, 2005).

648 . Innumerable works have been published on sugar, slavery, monoculture, and foreign investment. Just a sampling includes: Cepero Bonilla, Azúcar y abolición; Félix Goizueta-Mimó, Azúcar amargo cubano: monocultivo y dependencia economica (Madrid: Instituto de Sociologia y Desarrollo del Area Iberica, 1972); Ramiro Guerra y 
attention, however sugar's interconnected relationship with these three hot-button topics has resulted in sugar's otherwise overstated place of importance in colonial Cuban history. Unlike scholars have argued, the Cuban countryside was not an endless sea of ingenio after ingenio. In many areas during the late eighteenth and early nineteenth centuries, sugar did not represent a primary means of occupation for most residents, either free or slave. The crown chose tobacco, not sugar, as its preferred agricultural crop through the establishment of the monopoly, discussed in detail in an earlier chapter, which provided substantial revenue for Spain. Colonial officials from Madrid to Havana and the countryside realized tobacco's economic potential and were instructed to protect it.

\section{A Sugar-Free Countryside}

New research indicates that sugar did not play as important a role in many areas of rural Cuba as scholars have argued. ${ }^{649}$ Censuses and correspondence reveal that sugar plantations and the resulting infrastructure that accompanied them were either nonexistent or found in very small numbers throughout the Cuban countryside until at least the mid-

Sánchez, Azúcar y población en las Antillas (1927); Guerra y Sánchez, Sugar and Society in the Caribbean; Guerra y Sánchez, Pérez Cabrera, Remos, and Santovenia, Ilustración libertad de comercio (desde 1790 hasta 1837); Klein, Slavery in the Americas; Knight, Slave Society in Cuba; Moreno Fraginals, The Sugarmill; Robert L. Paquette, Sugar is Made with Blood: The Conspiracy of La Escalera and the Conflict Between Empires Over Slavery in Cuba (Middletown, CT: Wesleyan University Press, 1988); Oscar Zanetti and Alejandro García, Sugar and Railroads: A Cuban History, 1837-1959, translated by Franklin W. Knight, Mary Todd (Chapel Hill and London: The University of North Carolina Press, 1998).

649

Johnson, Social Transformation, 55, 186-87. 
1790s. Indeed, the number of vegas increased from 1783 to 1791 during the very period when sugar reportedly was displacing tobacco. ${ }^{650}$ Particularly west of Havana in the area known as Nueva Filipinas, tobacco dominated the region's agricultural pursuits during this period, as discussed in greater detail in an earlier chapter. Although western Cuba's association with tobacco is one that was touted at the time and continues to this day, it was not the only rural area where the documents demonstrate that sugar was not as pervasive as scholars have argued. Indeed, one scholar even goes so far as to argue that it was tobacco that laid the groundwork for the expansion of sugar. The money destined for payment of the crop, part of the situados, "injected important capital into the island, without which it would have been difficult to develop an industry with high investment requirements." 651

The area around Havana reputedly was the core of the island's sugar-growing region as early as the late-eighteenth-century. ${ }^{652}$ The expansion of sugar mills during the late-eighteenth and early-nineteenth centuries pushed aside the cultivation of tobacco and

650 . Guerra y Sánchez, Pérez Cabrera, Remos, and Santovenia, Ilustración libertad de comercio (desde 1790 hasta 1837), 9.

651 . Laura Náter, "The Spanish Empire and Cuban Tobacco During the Seventeenth and Eighteenth Centuries," in The Atlantic Economy During the Seventeenth and Eighteenth Centuries: Organization, Operation, Practice, and Personnel, edited by Peter A. Coclanis (Columbia: University of South Carolina Press, 2005), 272.

652. Moreno Fraginals, The Sugarmill, 20; Thomas, Cuba, or the Pursuit of Freedom, 77. Some scholars argue that sugar had become increasingly important even before the conquest of Havana by the British in 1762. See McNeill, Atlantic Empires of France and Spain, 127. 
other crops, notably in Güines, Santiago, and Bejucal, scholars have argued. ${ }^{653} \mathrm{~A}$

frequent example used to depict the invasiveness of sugar is the story of a wealthy veguero from Güines named José de Coca y Aguilar. According to the story, first told by Francisco de Arango y Parreño and since later repeated by others, in 1792, de Coca set fire to eleven tobacco barns on his own farm, destroying the tobacco inside, as a protest against the Real Factoria which had burned 58 loads of tobacco, the crop for the entire year. ${ }^{654}$ On the ruins of his farm, de Coca reportedly built the Nuestra Señora de las Mercedes sugar mill.655

Despite these claims, it is clear that Güines was not an exclusive sugar enclave. As early as 1768 the yearly tazmia noted 144 individuals who produced 12,430 cujes of tobacco. ${ }^{656}$ Between 1770 and 1771 , the number of vegas grew from 168 to 279 with workers increasing from 429 to 586.657 Tobacco production increased dramatically as

653 . Moreno Fraginals, The Sugarmill, 19-20, 22-23.

654 . Arango y Parreño, Obras, 461, 466; Guerra y Sánchez, Pérez Cabrera, Remos, and Santovenia, Ilustración libertad de comercio (desde 1790 hasta 1837), 9; Moreno Fraginals, El ingenio, 57; Moreno Fraginals, The Sugarmill, 23; Thomas, Cuba, or the Pursuit of Freedom, 77. The story is also discussed in Chapter 6. Despite the prevelance of this story in numerous works, no primary evidence has been found to date in either Spanish or Cuban archives that corroborates this account.

655 . Guerra y Sánchez, Pérez Cabrera, Remos, and Santovenia, Ilustración libertad de comercio (desde 1790 hasta 1837), 8; Moreno Fraginals, The Sugarmill; Thomas, Cuba, or the Pursuit of Freedom, 77.

656. Francisco Gama, "Tasmia General de los Cujes de Tabaco qe cada Labrador ha confezado haber cogido, en este Partido de los Guines y Sn Pedro de las Carreras este año de 1768," 14 April 1768, Güines, legajo 1090, PC, AGI.

657 . Johnson, Social Transformation, 54. 
well, rising to 270,850 cujes in 1771 , an increase of over 258,000 cujes in just three years. ${ }^{658}$ Although the number of vegas, workers, and tobacco produced were lower in 1774 and 1776 than in 1771 , this reflected a trend that occurred across virtually all of central and western Cuba from Matanzas to Nueva Filipinas. By 1776, however, tobacco production in Güines was beginning to recover from lows set the previous year, while other locations such as Xiaraco, Govea, and Matanzas continued in a downward direction. 659

The government desired a close link between Güines and the cultivation of tobacco and to that end the town was reorganized in 1786 as a "created community specifically to supply the royal monopoly." 660 As early as 1775 , tobacco had already been a mainstay of the local economy and society with 87 percent of the partido's 2,340 residents living on the area's 266 tobacco farms, while a mere 4 percent lived on three

658. Francisco Gama, "Tasmia de los Cujes de tabaco del Partido de Guines, respectiba a la Cosecha de este año de 1771," 15 May 1771, Güines, legajo 1090, PC, AGI.

659 . Francisco Gama, "Tazmia que comprehende el numero de Vegas, operarios y cujes de Tavaco qe ha confesado tener cada Labrador con destino á Seco en el Partido de los Guines, perteneciente á la Cosecha de mil setecientos setenta y quatro," 8 June 1774, Güines, legajo 1195, PC, AGI; Francisco Gama, "Tasmia que llo D Franco Gama da de los Vegas del Partido de Guines con noticia de los indibiduos que los cultiban, numero de cuxes que cada uno a confesado abercoxido ela [sic] presente Cosecha y la Tierra abierta que tiene cada Vega," 16 June 1776, Güines, legajo 1195, PC, AGI; Manuel Ramírez de Arellano, "Estado que manifiesta los Tabacos que han entregado los Labradores de este fruto en la Factor general de la Havana y Subalternas de la Ysla desde en año de 61 en que se estableció el Ramo por cuenta de la Real Hacienda hasta fin de 1803," 4 August 1804, tabla 9, signatura 9454, legajo 209, RC, ANC.

660 .Johnson, Social Transformation, 54; Marrero, Azúcar, ilustración y conciencia (1763-1868) (I), vol. 9 of Cuba: economía y sociedad, 218-220. 
local ingenios. Sugar's inroads into this particular community were limited at best and did not increase during this time as others have argued. Indeed, a local constable, Simon de Ayala, reported to Cuba's captain general in 1778, "Of the ingenios that fabricate sugar founded up to now, there are only four..."661 There was capacity, de Ayala noted, for an additional eight ingenios, but the 348 vegas by far outnumbered any other agricultural pursuit. ${ }^{662}$ Sugar's reputed invasion did not curtail the cultivation of tobacco with production in Güines remaining at high levels throughout the 1790 s and early 1800 s. Between 1790 and 1803, there were two years, 1799 and 1802, in which Güines produced more tobacco than all of the other partidos de la Habana, and it was the second highest producer in six of the twelve remaining years. ${ }^{663}$ By October 1792, Güines boasted only 11 ingenios as compared to 600 vegas, 30 potreros (pastures), and 11 cattle farms. Four years later, the number of sugar ingenios remained unchanged. In 1817, tobacco was forever linked to Güines when a royal decree approved the town's official coat of arms

\footnotetext{
661 . Simon de Ayala to Diego José Navarro, 15 June 1778, Güines, legajo 1267, PC, AGI.

662 . Ibid.

663 . Leví Marrero, Azucar, ilustración y conciencia (1763-1868)(I), vol. 9 of Cuba: economía y sociedad (Madrid: Editorial Playor, 1983), 217. In 1790-1791, 17951796,1800 , and 1803, only Guane or Govea produced more tobacco. Ramirez de Arellano, "Estado que manifiesta los Tabacos que han entregado los Labradores ...," 4 August 1804, tabla 9, signatura 9454, legajo 209, RC, ANC.
} 
depicting a tobacco plant, not sugar, on either side and below the villa's patron saint, Saint Julián. ${ }^{664}$

Clearly, high levels of tobacco production continued and the number of ingenios did not increase, yet what about the iconic story of José de Coca who was reported to have destroyed his tobacco and turned to sugar? No archival source corroboration of the story has been found, calling into question the voracity of the episode. Although the documentation may exist, Arango was far from an impartial observer. Half-owner of a sugar plantation, he supported development of the island's sugar industry and called for the end to the tobacco monopoly, a move which would effectively end the vegueros' protected market. 665 Sugar's hold over the area would not begin until after the end of the tobacco monopoly. Even as late as 1827, Güines had 107 vegas as compared to 47 ingenios and trapiches (sugar mills). The 1838 opening of the island's first railroad line from Havana to Güines at an estimated cost of 2,005,479 pesos caused Güines's sugar industry to expand markedly, and by 1862 , the number of sugar estates and mills had grown by 24 in just 16 years and now numbered 90.666

Güines, however, was not an isolated example of sugar failing to overtake tobacco as the preferred crop during the late-eighteenth-century. Sugar played a small or

664 . Güines report of itself, 15 October 1792, Güines, legajo 1471, PC, AGI; Johnson, Social Transformation, 55; Marrero, Cuba: economía y sociedad, 24. More information on Arango is found in an earlier chapter.

665 . Johnson, Social Transformation, 125-28; Kuethe, Cuba, 1753-1815, 122.

666. Marrero, Azúcar, ilustración y concencia (17631-1868) (I), vol. 9 of Cuba: economía y sociedad, 221; Zanetti and García, Sugar and Railroads, 34. 
insignificant role as compared to tobacco in other areas of the island during the mid-

1770s. In San Juan de Jaruco, located just under halfway between Havana and Matanzas, there were 23 vegas, and no ingenios. ${ }^{667}$ This was not a phenomenon limited to the Havana area alone as central Cuba was much the same. In the partido of Santi Spirítus, tobacco farms outnumbered sugar plantations by a ratio 5 to 1 . Similar results were seen in the area around Trinidad as well. During the mid 1770s, there were 178 vegas compared to 41 ingenios. Although the number of vegas dipped in 1782 to 97 , they quickly rebounded, rising to 164 the following year. 668

Even after the turn of the nineteenth century the Cuban countryside remained dedicated to the cultivation of tobacco over sugar. Vegas outnumbered ingenios in all three departments by at least 5 to 1 as early as 1827 , and there were more tobacco farms than any other agricultural activity, with the exception of general farms (estancias y sitios de labor) throughout the island as a whole. ${ }^{669}$ The number of tobacco farms only

667 . Pablo Perez, Tazmia, 4 July 1777, San Juan de Jaruco, legajo 1268, PC, AGI; Diego José Navarro, "Estracto del padron general de havitantes de la isla de Cuba, correspondiente a fin de Diciembre de 1778, Havana, 31 diciembre 1778," typescript copy in Revista de la Biblioteca Nacional José Martí, 29 (septiembre-deciembre 1987): 25.

668 . Tomas José Cadenas, Tazmia, 2 August 1776, Sancti Spirítus, legajo 1176, PC, AGI; Navarro, "Estracto del padrón general..." Revista de la Biblioteca Nacional José Martí 29 (September - December 1987): 25; Fernando Muñoz, Tazmia, 24 May 1776, Trinidad, legajo 1186, PC, AGI; Fernando Muñoz, Tazmia, 26 February 1782, Trinidad, legajo 1313, PC, AGI.

669 . Guerra y Sánchez, Pérez Cabrera, Remos, and Santovenia, Ilustración libertad de comercio (desde 1790 hasta 1837), 73, 178; "Fincas rurales de la Provincia en 1827," Memorias de la Sociedad Economica de Amigos del Pais, II, vol. 145, page 206, LM, SC, GL, FIU. 
continued to grow over the next few decades, and by 1846 , they rose to 9,102 . Although eastern Cuba saw the greatest increase in the percentage of tobacco farms, up to 45 percent from just 19 years before, the western department remained committed to tobacco cultivation, containing nearly 44 percent of the island's vegas in 1846.670 Similarly, "the total number of people engaged in tobacco production nearly doubled during the intercensus years of 1846 and 1862, from 32,248 to 58,039."671 Western Cuba remained predominantly a tobacco-growing area as the century progressed. In 1862 , the jurisdiction of Nueva Filipinas had 3,616 tobacco farms and 5 sugar plantations, a ratio of over 750 to 1 . Sugar wasn't even the region's second or third-most common agricultural endeavor with 497 pastures and 86 cattle farms far outnumbering land dedicated to the cultivation of cane. ${ }^{672}$

Not only were sugar ingenios not as prevalent from 1763 to 1817 as many scholars of Cuba claimed, they were not the primary source of employment for enslaved or free agricultural workers. The incredible demand for African slaves after 1800 was due to sugar growers' demands for labor, yet "the overwhelming bulk of the Negroes on Cuba neither lived nor worked on the great sugar plantation during the entire period of Cuban slavery. So diversified had the Cuban economy became that despite its

670 . Humbolt, The Island of Cuba, 280.

671 . Pérez, Winds of Change, 95.

672 . Dollero, La Provincia de Pinar del Río, 318-19. 
importance, sugar employed only a minority of the slaves, even in the 1860s."673 Instead, vegas and cattle estates were home to an estimated 25 to 50 percent of Cuba's rural slave population. ${ }^{674}$

Cuba's tobacco industry provided employment for tens of thousands of people during the colonial period. While the most obvious beneficiaries were the vegueros, many more individuals owed their livelihoods to tobacco including the muleteers who carried tobacco to the royal storehouses, the bureaucrats responsible for administering the monopoly, members of the resguardo responsible for enforcing monopoly regulations, and workers in Cuba's and Spain's factorias who turned the raw product into one ready for consumers. A sampling of tazmias from just thirteen partidos in 1770 reveals that 1,243 people, both free and slave, worked in Cuba's tobacco fields. ${ }^{675}$ At the highest year of tobacco production under the monopoly, $1788,10,000$ heads of households were

\section{3 . Klein, Slavery in the Americas, 150-51.}

674 . Klein, Slavery in the Americas, 158. Slaves were a valuable source of labor in the tobacco fields, particularly for planting and caring for the crop, as discussed in detail in earlier chapters.

675 . Agustín Hernandes Pulgaron, Tazmia, Partidos de Bacuranado y San Jeronimo, 6 April 1770, Guanabacoa, legajo 1090, PC, AGI; Luis Echevarria y Egueria, Tazmia, Partido de Mayari, 12 April 1770, Mayari, legajo 1080, PC, AGI; Joaquin de Sola, Tazmia, Partidos de Concepción al Norte, Saramaguacan al Norte, Arenillas al Norte, Guariao al Sur, and Guanausi al Sur, 25 May 1770, Puerto Principe, legajo 1085, PC, AGI; Ramon José Rodriguez, Tazmia, Partido de Yumuri, 26 May 1770, Matanzas, PC 1090, AGI; Ramon José Rodriguez, Tazmia, Partidos de Naranjal, Estancias y San Agustín, 15 May 1770, legajo 1090, PC, AGI. 
dedicated to the cultivation of tobacco. ${ }^{676}$ In 1817 , the final year of the monopoly, 8,775 people worked in the island's tobacco fields. ${ }^{677}$

\section{Tobacco's Economic Impact}

As discussed in previous chapters, tobacco's popularity and economic potential led to the creation of a Spanish monopoly on tobacco. Through the monopoly the crown sought to control the cultivation, processing, and production of tobacco and its resulting products. Some argue that from its early days tobacco was not intended as a capitalistic, commercial venture for Spain as it was for places like Virginia. ${ }^{678}$ This work has demonstrated, however, that Madrid took definitive measures to ensure that it partook of the potential revenue deriving from this plant. These actions extended far beyond the implementation of the monopoly. Tobacco was always purchased by the crown even during wartime when transatlantic shipments of sugar were prohibited. ${ }^{679}$ Beginning in 1798 , Spain sought to protect tobacco growers from large landowners with a series of

\footnotetext{
676 . Guerra y Sánchez, Pérez Cabrera, Remos, and Santovenia, Ilustración libertad de comercio (desde 1790 hasta 1837), 9.
}

677 . José Gonzalez, "Resumen general de la visita y reforma practica por la Factoria de Tabacos en los ríos y tierras de la isla de Cuba, para reconocer las vegas realengas en cultivo ó eriales, y las de particulares en terrenos apartados: el cual se ha extraido del Plan demostrativo que numera los plantios, agricultores, y sumas de ojas cosechables anualmente, para disponer fondos: todo ello segun Reglamentos, segun Instruccion de 12 de Octubre de 1803 y segun Orden de 9 de Enero de 1812," Real Factoría de tabacos, La Habana, 31 May 1817, legajo 2019, SD, AGI.

678 . Ortiz, Cuban Counterpoint, 59.

679 . Johnson, Social Transformation, 56. 
decrees. Cuba's captain general, Juan Procopio Bassecourt, the Conde de Santa Clara, was "authorized to use every means in his power to enforce the decrees, including the use of regular troops, and he warned that 'in the name of His Majesty he would take the most severe measures against any of them [the large landowners] who contravened his royal intent." "680 Preferential treatment was extended to the vegueros on other occasions as well. In 1801, an existing exemption on the payment of diezmos (tithes) for those who grew tobacco was extended by the king for an additional ten years. To further protect the vegueros in 1803, the captain general was named "the official guardian of their interests." $" 681$

One indication of tobacco's impact on Cuba's colonial economy was the sheer size of tobacco production. Between 1761 and 1803, 5,876,844 arrobas or almost 149 million pounds of tobacco were produced throughout Cuba. Production peaked in 1788, reaching almost 342,000 arrobas or about 8.6 million pounds. Production in Güines alone during this 43-year period totaled 706,440 arrobas or over 17.9 million pounds. ${ }^{682}$

680 . Ibid., 172-73.

681. Johnson, Social Transformation, 173. Preferential treatment for vegueros was not just limited to Cuba. In Mexico, sugar hacendados complained that the Crown unfairly intervened on behalf of tobacco farmers. See Deans-Smith, Bureaucrats, Planters, and Workers, 108.

682 . Manuel Ramires de Arellano, "Estado que manifiesta los Tabacos que han entregado los Labradores...," Havana, 4 agosto 1804, signatura 9424, tabla 9, legajo 209, $\mathrm{RC}, \mathrm{ANC}$. Total production figures were $148,978,004$ pounds. The amount of tobacco produced in 1788 was 341,984 arrobas and 11 pounds. Production in Güines was 706,440 arrobas and 8 pounds. An arroba is equivalent to 25.35 pounds or 11.5 kilograms. See Guerra y Sánchez, Sugar and Society in the Caribbean, 42. 
The estimated value of Cuban tobacco sent to Spain between 1760 and 1810 was 100 million pesos, accounting for 25 percent of Spain's total revenue during that period.

Since these figures do not take into account clandestinely grown or sold tobacco that did not reach the Real Factoría, this amount should be considered a mere starting point. ${ }^{683}$

Another way in which to measure the economic size and importance of tobacco to the crown can be seen by examining the personnel outlays and capital infrastructure that helped the monopoly to function. The vast amount of money invested in both salaries and physical capital indicates that the Spanish government considered tobacco to be a profitable enterprise. Salaries within the monopoly ran the gamut between several hundred pesos per year to several thousands. Even within the resguardo, salaries varied widely. Those in the resguardo a caballo earned more than those in the regular resguardo but were also responsible for maintaining the horse, rifle, pair of pistols, and sword assigned to them. The head corporal (cabo principal) of the resguardo a caballo in Havana and surrounding area earned 730 pesos, and a guardo a caballo made 547 pesos per year. Members of the non-mounted resguardo earned significantly less. A corporal or a guardo in the non-mounted resguardo earned 360 or 240 pesos per year respectively. In all, salaries paid to those associated with the resguardo and in charge of protecting the monopoly's interests totaled 15,677 pesos annually according to a 1778

683 . de la Sagra, Historia economico-politica y estadistica, 240-66 cited in Carlos Marichal, Bankruptcy of Empire: Mexican Silver and the Wars Between Spain, Britain, and France 1760-1810 (Cambridge: Cambridge University Press, 2007), 38. As noted in an earlier chapter, scholars argue that a sizeable amount of tobacco was grown and traded clandestinely and never made it to the official market. 
report. 684 The Director General de la Renta by contrast had an annual salary of 3,000 pesos. 685

This was merely an economic drop in the bucket compared to the value of the capital goods owned by the monopoly. An end-of-year accounting of all Real Factoríaowned possessions throughout the island noted their value at almost $1,772,000$ pesos. Possessions in Havana alone accounted for over 1.5 million pesos including the building housing the tobacco factory, assessed at $1,238,890$ pesos, and 62 slaves valued at 18,000 pesos. The actual value of properties and goods related to the tobacco industry was even higher, since in "many provinces there are no casas del Rey" because the necessary facilities were rented from private individuals. .686

Another obvious expense to the crown was the purchase of tobacco from the vegueros. Although farmers frequently complained about the prices they were paid for their crop, charges that dated back to the earliest days of the monopoly, the willingness to outlay sizable amounts of money demonstrated the value that the Spanish government

684 . Juan Ignacio de Urriza, "Nomina de los individuos que componen el Resguardo Rentas reales de la Ciudad de la Havana, y su campo, informe al Reglamento aprobabo por S.M. con fecha de Julio de presente año," 28 September 1778, Havana, orden 148 , legajo 1114 , IGH, ANC.

685 . Don Braulio de Vivanco, Employment Sheet, Havana, 31 August 1817, legajo 2019, SD, AGI.

686. "Noticia del estado de posesiones y enseres de la Factoría de Tabacos de la Habana en fin de Diciembre de 812 , copiada del numero $4^{\circ}$ de las cuentas del propio año, con expresion de las valores," no date, legajo 2001, SD, AGI. 
placed on tobacco. ${ }^{687}$ In $1723,200,000$ pesos of the money sent annually from New

Spain to Cuba to cover the island's expenses known as the situado was designated for the purchase of tobacco, but by 1744 , this figure rose to 500,000 pesos. ${ }^{688}$ Clearly Madrid believed that it would not only recoup these expenses through the sale of tobacco, but hoped to make a respectable profit as well. Between 1751 and 1755 , the crown sent Lieutenant (junior grade) don Manuel de Quintana and arriero Pedro Hernández repeatedly into the interior to transport funds to pay the vegueros. In just four documented trips during the late spring or summer of $1751,1752,1754$ and 1755 they carried 137,359 pesos to local officials to pay for the purchase of that year's tobacco crop. ${ }^{689}$ Between 1773 and 1776, 34,000 pesos in two payments were sent to San Juan de Remedios alone to pay for the purchase of the area's tobacco. ${ }^{690}$

Payment to the vegueros for their crop and the salaries and physical infrastructure needed to operate the Cuban tobacco monopoly involved a sizable financial investment on the part of the Spanish crown. Was it financially worth it? Various estimates of the

687 . Rivero Muñiz, Las tres sediciones, 20.

688 . Marichal, Bankruptcy of Empire, 38.

689 . Francisco Cagigal de la Vega to Alonso de Arcos y Marrero, 30 April 1751, Havana, orden 239, legajo 7, CG, ANC; Governor of Cuba to Francisco Cagigal de la Vega, 7 June 1752, Santiago de Cuba, orden 234, legajo 6, CG, ANC; Francisco Cagigal de la Vega to Alonso de Arcos y Moreno, 30 April 1754, Havana, orden 207, legajo 7, CG, ANC; Francisco Cagigal de la Vega to Lorenzo de Madriaga, 20 July 1755, Havana, orden 89 , legajo $7, \mathrm{CG}, \mathrm{ANC}$.

690. Antonio de la Torre to Marques de la Torre, 6 December 1773, San Juan de los Remedios, legajo 1185, PC, AGI; Antonio de la Torre to Marques de la Torre, 15 January 1776, San Juan de los Remedios, legajo 1185, PC, AGI. 
impact of the tobacco monopoly on Cuba and the Spanish crown exist, but all agree that

tobacco was indeed a profitable enterprise for Madrid. One scholar argues,

...the crown realized profits of between 500 and 600 percent

on the tobacco renta, producing an annual revenue of

between 7 and 10 million pesos from 1740 to 1760 . This

profit, large enough to finance the entire Spanish navy, easily met the costs of governing and defending Cuba.

Even after a dramatic increase in the Havana budget (1740-

43), Cuban administrative costs normally came to less than a third of the profit garnered from Cuban tobacco. This profit amounted to about one-fifth the value of the output of Peruvian mines in the same years, or between one-fourth and one-third of the income of the Spanish fisc. 691

A small mirror into the crown's economic windfall made possible by the Cuban tobacco industry can be seen in the profits brought in from selling loose and ground tobacco to the Cuban public. Between 1763 and 1803, sales of these items on the island totaled nearly 2.5 million pesos. 692

After the monopoly was abolished in 1817 , tobacco did not fade into Cuba's colonial past and instead the industry expanded even against the onslaught of sugar. In 1811 , there were 4,960 vegas and by 1827 increased to 5,534. Trinidad alone in the late 1820 s had 460 vegas. Reportedly 14,263 slaves worked on the island's tobacco farms in 1830. Tobacco production rose as well from 9.3 million pounds in 1811 to 12.5 million

691. McNeill, Atlantic Empires of France and Spain, 158.

692 . Manuel Ramirez de Arellano, "Estado que manifiesta el Caudal que ha ingresado en Factoría, por valor de los Tabacos rama y polvo, vendidos para consumo publico, desde el establecimiento del Ramo, por cuenta de la Real Hacienda, el año 1761," Havana, 4 August 1804, signatura 9424, tabla 11, legajo 209, RC, ANC. 
pounds in 1827 and 22.5 million by 1836.693 Natural disasters in the form of hurricanes, heavy rains, and droughts during the 1840 s were particularly devastating to tobacco. Even before the San Francisco de Borja hurricane of 1846 hit, a resident of Guane in the far western part of the island complained that the damage to the area's tobacco industry was irreparable. Most of the 1846 tobacco harvest was destroyed along with seeds and the previous year's tobacco held in storage sheds and warehouses. Out of 76,000 plants on one vega in Govea, none survived, while seed beds around Artemisa, Alquízar, and San Antonio de los Baños were wiped out. This was particularly devastating as it followed on the heels of a hurricane just two years earlier, yet the island's tobacco industry "eventually emerged as another long-term beneficiary of the devastation wrought by the hurricanes of the 1840 s." 694

\section{The Tobacco Monopoly in Context}

To get a more complete picture of the magnitude of Cuba's tobacco industry and its impact on the island's colonial economy it is necessary to examine it in context and compare it to other colonial enterprises and expenditures. As early as the first half of the eighteenth century, tobacco in Cuba garnered a sizable portion of the Spanish budget. While the funds designated for maintaining Havana's military garrison from the annual New Spain situado in 1744 was 400,000 pesos, an additional 100,000 pesos were needed

693 . Pérez, Winds of Change, 47-48, 54.

694 . Tbid., 69, 79-80, 94. 
just to pay the island's vegueros for the tobacco purchased by the monopoly ${ }^{695}$ By comparison during the same time, Chile received a little more than 292,000 pesos annually for the border troops that helped protect the region. During the 1750 s this figure was reduced to 100,000 pesos. 696

Despite Cuba's longtime association with tobacco, it was not the only location in Spain's empire where a tobacco monopoly was instituted. As noted in an earlier chapter in greater detail, Spain established monopolies in most of its overseas holdings during the eighteenth or nineteenth centuries, and while Cuba's monopoly is the focus of this study in many ways the Cuban experience was not an anomaly. Production numbers were far lower but nevertheless Spanish Louisiana shipped about 220 tons of tobacco annually left New Orleans and was carried to Veracruz and other locations in Mexico between 1778 and 1789.697 Around the same period, 1770 to 1796 , tobacco exports from nearby Santo Domingo on the island of Hispaniola to Seville averaged around 5,410 arrobas or about 137,144 pounds annually. 698 Production varied significantly, yet the bureaucracy associated with the tobacco monopoly remained fairly unchanged throughout Spanish America where salaries constituted a sizable portion of the tobacco monopoly's budget. Salaries in the Factoria General de Santiago de Guatemala during the mid-eighteenth

695. Marichal, Bankruptcy of Empire, 38.

696. Stapff, "La renta del tabaco en el Chile de la época virreinal," 25.

697 . Suárez Argüello, Camino real y carrera larga, 120-21. For Louisiana’s tobacco industry, see Coutts, "Boom and Bust."

698 . Gutiérrez Escudero, "El tabaco en Santo Domingo," 135. 
century were at least 8,400 pesos annually, whereas Venezuela's tobacco monopoly paid out nearly 39,000 pesos in wages to its employees in $1783 .{ }^{699}$ By 1788, Mexico's monopoly employed 17,256 people. The majority of employees received lower levels of remuneration, but the directores generales and those holding the combined office of contador and director could expect to earn 6,000 pesos per year, while factores received 2,000 pesos annually. ${ }^{700}$

In order to justify such expenditures, the resulting revenues needed to be at least on par or higher, but luckily for the Spanish crown, tobacco was a proven money-maker. The New World plant had a long history of economic potential, one that was realized by European powers as early as the seventeenth century. One scholar of tobacco notes that "...until the 1640s, tobacco was the most profitable staple in the English Caribbean." was not only Britain that enjoyed the benefits of trade and sale of tobacco. Portugal too enjoyed the financial benefits of tobacco and "by the end of the seventeenth century... [it] became an important article of Portuguese trade and a significant source of state income." 702 For Spain, tobacco was more than just an industry in which it could claim that the crown exercised complete control, it was also profitable.

699 . Luján Muñoz, "El establecimiento del Estanco del Tabaco en el Reino de Guatemala," 7-8; Arcila Farias, Historia de un monopolio, 39-42.

700 . Deans-Smith, Bureaucrats, Planters, and Workers, 45-46.

701 . Goodman, The Cultures of Dependence, 180.

702 . Lugar, "The Portuguese Tobacco Trade and Tobacco Growers of Bahia in the Late Colonial Period," 36. 
From Spain's holdings in Cuba, to Mexico and the Philippines, tobacco constituted a significant source of revenue for the crown. Described as "the largest commercial and manufacturing enterprise in New Spain," between 1782 and 1809 revenues from New Spain's tobacco monopoly exceeded 3 million pesos per year. ${ }^{703}$ By the end of the eighteenth century revenues from the monopoly exceeded that of "any other single source" except the region's famed mines. ${ }^{704}$ At its highest point in 1798, profits reached $4,539,796$ pesos, and contributed about 22 percent of the colony's total revenue. While this figure may seem high, it was not an anomaly as the monopoly regularly averaged about 15 percent of New Spain's annual revenue. ${ }^{705}$ Similar results were seen even as far away as the Philippines where "by the 1790s, the monopoly had become the colony's most productive source of revenue."706 In only its second year of operation, the Philippine tobacco monopoly delivered 150,000 pesos to Spain, profits headed directly to the royal treasury as dictated by royal order. Nearly 2 million pesos went into the Spanish treasury from the Philippine monopoly by the end of the eighteenth century. ${ }^{707}$ The money earned from tobacco not only helped the crown's coffers in Spain, but also

703 . David W. Walker, "Business as Usual: The Empresa del Tabaco in Mexico, 1837-1844," Hispanic American Historical Review 64, no. 4 (November 1984): 675; McWaters, "Royal Tobacco Monopoly in Bourbon Mexico," 1.

704 . McWaters, "Royal Tobacco Monopoly in Bourbon Mexico," 1; de Jesus, The Tobacco Monopoly in the Philippines, 10.

705 . McWaters, "Royal Tobacco Monopoly in Bourbon Mexico," 1, 277.

706 . de Jesus, The Tobacco Monopoly in the Philippines, 84.

707 . Tbid., 84-85. 
financed projects in its colonies. Funds from the monopoly were used by the Philippine governor, Rafael María de Aguilar, to pay for a buildup of islands' defenses in 1795 and 1796..$^{708}$ A scholar of the Mexican tobacco monopoly argues that the monies earned from Mexican tobacco monopoly "played a pivotal role in the financing of an empirewide tobacco monopoly." 709 The monopoly was not successful in all areas of Spanish control however. The profits earned by Guatemala's monopoly, averaging 37,805 pesos annually were small in consideration of the effort expended and problems the monopoly generated, one scholar argues. ${ }^{710}$

Throughout the eighteenth century, the Bourbon monarchs attempted to transform interactions between their overseas territories and the crown in order to consolidate and reinvigorate Spanish rule. Four concerns--commerce and the economy, the military, culture and religion, and administration--constituted the primary foci of the Bourbon Reforms. These reforms were often interconnected as their efforts to control trade and eliminate illicit commerce demonstrated. ${ }^{711}$ As described throughout this work, the royal

708 . Ibid., 85 .

709 . Deans-Smith, Bureaucrats, Planters, and Workers, 61.

710 . Luján Muñoz, "El establecimiento del estanco del tabaco en el reino de Guatemala," 17.

711 . Other products were similarly controlled by the Bourbons through royal monopolies. One such monopoly was the one on the popular cane brandy known as aguardiente established when the Spanish government was unable to prevent the sale of aguardiente in the late seventeenth century. Discussed in royal orders in 1700 , it was not until 1710 that the monopoly really began to function. While the monopoly on aguardiente was responsible for substantial contributions to the treasury, local opposition led to a decrease in revenues, Anthony McFarlane notes. While he does not indicate 
monopoly on tobacco dictated that Cuban tobacco farmers deliver all of their product to designated officials. While clearly this was an economic reform, the Spanish military system was also involved particularly because illicit commerce continued and the crown was forced to address the issue of illegal trade as this work has demonstrated. The use of guardacostas, charged with preventing the intrusion of foreigners intent on smuggling, and the formation of the enforcement bureau of the tobacco monopoly, the resguardo, were just two examples of the merging of economic and military elements of the Bourbon Reforms.

\section{Tobacco in Perspective}

At least since the nineteenth century, chroniclers and scholars of Cuban history have argued that tobacco was a pursuit of the lower classes. Faithfully tending to row after row of tobacco plants, the image of the poor, white tobacco farmer became ingrained in the fabric of not only Cuban history, but the island's cultural and political life as well. Again placing tobacco and sugar in contrast, Fernando Ortiz wrote

whether this decrease was due to contraband, such illicit commerce may have contributed to this decline. The monopoly was temporarily abandoned and reinstated in 1736 , after a 22 year suspension. Anthony McFarlane, Colombia Before Independence: Economy, Society, and Politics Under Bourbon Rule, Cambridge Latin American Studies (Cambridge: Cambridge University Press, 1993), 200-01. See also Gilma Lucía Mora de Tovar, Aguardiente y conflictos sociales en la Nueva Granada durante el siglo XVIII (Bogotá: Universidad Nacional de Colombia, Centro Editorial, 1988). For additional monopolies see James A. Lewis, "The Royal Gunpowder Monopoly in New Spain: 17661783: A Case Study of Management, Technology, and Reform Under Charles III," IberoAmerikanisches Archiv 6, no. 4 (neue Folge 1980): 355-72; D.A. Brading, Miners and Merchants in Bourbon Mexico, 1763-1810 (Cambridge: Cambridge University Press, 1971). 
The personal element always predominated in tobaccogrowing, and there was a patriarchal, intimate quality about its work. Sugar was an anonymous industry, the mass labor of slaves or gangs of hired workmen, under the supervision of capital's overseers. Tobacco has created a middle class, a free bourgeoisie; sugar has created two extremes, slave and masters, the proletariat and the rich. ${ }^{712}$

To Ortiz and others, the veguero represented the quintessential small farmer, living on a small plot of land that he may not have even owned, and employing methods of agriculture probably not that different than those used generations earlier. The veguero, therefore, characterized an earlier, more rustic era, while those who grew sugar symbolized the plantation system and a proto-industrial step toward capitalism itself. ${ }^{713}$

Tazmias provide one of the best windows into the composition of those owning or renting land on which tobacco was grown. It is these period documents, along with other sources, which clearly indicate that the existing historiographical image of the veguero as a poor, white, Canary Islander is inaccurate at best. As this study has indicated, people of color, both slave and free, worked alongside their white counterparts in the island's tobacco industry from 1763 to 1817 . The prevailing historiographical view of Cuba's colonial tobacco farmers, particularly those in western Cuba, as consisting exclusively of white, Canary Islanders deserves substantial revision. Clearly, Cuba's veguero population was far more diverse and complex than the literature currently suggests.

The various groups from which Cuba's vegueros were drawn, as discussed in detail elsewhere in this study, was not an anomaly limited only to the island. Vegueros in other Latin American locations such as Mexico also covered a vast spectrum of that colony's society in which poor farmers and Indians, as well as the wealthy, all grew

712 . Ortiz, Cuban Counterpoint, 65.

713 . Ibid., 71, 252, 289. 
tobacco. Indeed, one of the most prominent planters in Orizaba, Mexico offered to expand his production allotment to between 12 and 13 million tobacco plants, an amount of tobacco that would cover approximately 2,400 acres. His existing allotment was 6.5 million plants, significantly higher than most other vegueros in the area who tended between 50,000 and 300,000 plants. 714 The presence of members of the nobility was also found in Mexico where the largest tobacco landholders in Orizaba and Córdoba were the Conde del Valle de Orizaba, the Marqués de Valle de la Colina, and the Marqués de Sierra Nevada, all absentee owners who rented out their properties..$^{715}$

The presence and importance of people of color in Cuba's tobacco production provides a better understanding of the labor force that contributed to bring this valuable crop to market. While the impact of tobacco-growing on the ability of slaves working in the fields to earn enough money to purchase their freedom still needs further exploration, it is clear that tobacco offered another avenue for Cuba's people of color. The plant may have even provided a way to further integrate themselves into the general population in terms of social and economic opportunities that would otherwise not have been available. With the exception of noting slaves that labored in tobacco for their own benefit, tazmias usually did not indicate the names, status, or other identifying information about each individual worker on the vega and instead listed their numbers under the general label of operarios. While one might reasonably assume that a vega listed as having one "worker including the owner" meant that the owner alone tended to the tobacco, it is difficult for us to know whether this was accurate as an owner might have employed a hired hand or slave to labor in the fields.

714 . Deans-Smith, Bureaucrats, Planters, and Workers, 11, 87, 386.

715 . Ibid., 111. 
This study has demonstrated that slaves, free blacks, and women were vital members of the veguero community. Yet, this work is not primarily an examination of race, slavery or gender. Ortiz was indeed correct when he claimed that "tobacco has always been more Cuban than sugar," the plant can be used as the vehicle to understand all aspects of rural colonial Cuban society. ${ }^{716}$ Whether or not the person listed as owner or veguero, be they poor or among the highest members of Cuban society, personally worked in the fields is ultimately of little importance. The mere fact that diverse groups of people including those with sufficient social standing to be called "don," free blacks, slaves, members of the military, clergy, and even those with noble titles or women grew tobacco or had it grown on their behalf is significant and completely alters the existing view of rural Cuban society during the late eighteenth and early nineteenth centuries.

Perhaps in an attempt to explain Cuba's dependence on sugar in the twentieth century, historians and other scholars projected back in time in an attempt to understand how Cuba got to where it was. Whether or not this is the underlying reason for the academic overemphasis of sugar and the topics surrounding it such as slavery, monoculture, and foreign investment, this study challenges the belief that all Cuban history must be viewed through the crystalline prism of sugar. The Cuban countryside during the late-eighteenth and early-nineteenth century was a diverse setting with many agricultural pursuits in which its residents could engage. Tobacco was not the only one of these, but as this study has argued, its effects went far beyond the symbolic association of Cuba and a good cigar. Those who grew tobacco during this time, the vegueros, represented the width and breadth of Cuban rural society--whites, blacks, freed people, slaves, lowly peasants, and those with noble titles. Their resistance to the royal tobacco monopoly manifested in outright contraband, sloppy production habits, and demands for

716 . Ortiz, Cuban Counterpoint, 61. 
improved terms demonstrates that the Bourbon monarchs were not all-powerful lords presiding uncontested over their subjects. 


\section{BIBLIOGRAPHY}

Abbot, Abiel. Letters Written in the Interior of Cuba, Between the Mountains of Arcana, to the East, and of Cusco, to the West, in the Months of February, March, April, and May, 1828. Boston: Bowles and Dearborn, 1829.

Aimes, Hubert H.S. A History of Slavery in Cuba, 1511-1868. New York: Octagon Books, 1967.

Alfonso Mola, Marina. "Corso y flota de Indias: Los convoyes ingleses apresados en 1780 y 1795." In Andalucia, America y el Mar, edited by Bibiano Torres Ramirez. Actas de las IX jornadas de Andalucia y America (Universidad de Santa Maria de la Rabida), 197-270. Seville, 1989.

Alford, B.W.E. W D. \& H.O. Wills and the Development of the U.K. Tobacco Industry, 1786-1965. London: Methuen and Company, 1973.

Un Amigo del Pais. Memoria sobre el tabaco de la isla de Cuba, en la que se indican algunas mejoras de que es susceptible su cultivo y preparacion. Habana: Imprenta de Antonio María Davila, 1852.

Andrews, Charles M., ed. Narratives of the Insurrections, 1675-1690. 1915. New York: Bames and Noble, 1967.

Andrews, Kenneth R. Elizabethan Privateering: English Privateering During the Spanish War, 1585-1603. Cambridge: Cambridge University Press, 1964.

----.. The Spanish Caribbean: Trade and Plunder 1530-1630. New Haven: Yale University Press, 1978.

Arana de Varaflora, Fermín. Compendio historico descriptivo de la muy noble y muy leal ciudad de Sevilla metropolí de Andalucía formabalo don Fermín Arana de Varaflora, natural y vecino de dicha Ciudad, 1789.

Arango y Parreño, Francisco de. Obras del Exmo. Señor D. Francisco Arrango y Parreño. Vol. 1. Habana: Howson y Heinen, 1888.

Arango y Parreño, Francisco. De la Factoria a la colonia. La Habana: Secretaria de Educación, Dirreción de Cultura, 1936.

Araúz Monfante, Celestino Andrés. "La acción ilegal de los holandeses en el Caribe y su impacto en las Antillas y Puerto Rico durante la primera mitad del siglo XVIII." Revista/Review Interamericana 14, no. 1-4 (primavera-invierno 1984): 67-79. 
Archer, Christon I. The Army in Bourbon Mexico, 1760-1810. Albuquerque: University of New Mexico Press, 1977.

Arcila Farias, Eduardo. Historia de un monopolio: El estanco del tabaco en Venezuela 1779-1833. Caracas: Ediciones de la Facultad de Humanidades y Educación, Universidad Central de Venezuela, 1977.

Armytage, Frances. The Free Port System in the British West Indies: A Study in Commercial Policy, 1766-1822. London: Longmans, Green, and Co., 1953.

Axton, W. F. Tobacco and Kentucky. Lexington: The University Press of Kentucky, 1975.

Aycock, William Brantley. "Tobacco Regulation in Colonial Virginia." M.A. thesis. Chapel Hill, NC: University of North Carolina, 1937.

Bailyn, Bernard. "The Idea of Atlantic History." Itinerario 20 (1996): 19-44.

Ballou, Maturin M. Due South; or Cuba, Past and Present. Boston and New York: Houghton, Mifflin, 1885.

Barbour, Violet. "Privateers and Pirates of the West Indies." The American Historical Review 16, no. 3 (April 1911): 529-66.

Barcia, María del Carmen. "Clases sociales y tabaco: comentarios en torno a su producción y estanco (desde sus inicios hasta principios del siglo XIX." Santiago 65 (June 1987): 107-43.

Barickman, B.J. "A Bit of Land, Which They Call Roca: Slave Provision Grounds in the Bahian Reconcavo, 1780-1860.” Hispanic American Historical Review 74, no. 4 (November 1994): 649-87.

Baud, Michiel. Peasants and Tobacco in the Dominican Republic, 1870-1930. Knoxville: University of Tennessee Press, 1995.

Bergad, Laird W. Cuban Rural Society in the Nineteenth Century: The Social and Economic History of Monoculture in Matanzas. Princeton, New Jersey: Princeton University Press, 1990.

Bergamini, John D. The Spanish Bourbons: The History of a Tenacious Dynasty. New York: G.P. Putnam's Sons, 1974.

Berkhofer, Robert F., Jr. Beyond the Great Story: History as Text and Discourse. Cambridge and London: Belknap Press of Harvard University Press, 1995. 
Billings, E.R. Tobacco: Its History, Varities, Culture, Manufacture and Commerce. Hartford, CT: American Publishing, 1875.

Blackburn, Robin. The Making of New World Slavery: From the Baroque to the Modern 1492-1800. London and New York: Verso, 1997.

Boswell, Thomas D. "The West Indies: The Hispanic Territories and Haiti." In Middle America: Its Lands and Peoples, edited by Robert C. West and John P. Augelli, Thomas D. Boswell and et. al., 128-67. Englewood Cliffs, N.J.: Prentice Hall, 1989.

Bowser, Frederick P. "The Free Person of Color in Mexico City and Lima: Manumission and Opportunity, 1580-1650." In Race and Slavery in the Western Hemisphere: Quantative Studies, edited by Stanley L. Engerman, Eugene D. Genovese, 331-68. Princeton: Princeton University Press, 1975.

Boyer, Richard. Lives of the Bigamists: Marriage, Family, and Community in Colonial Mexico. Albuquerque: University of New Mexico Press, 1995.

Boyle, Susan Calafate. Los Capitalistas: Hispano Merchants and the Santa Fe Trail. Alberquerque: University of New Mexico Press, 1997.

Brading, D.A. "Bourbon Spain and Its American Empire." Historical Journal 24, no. 4 (1981): 961-69.

-----. Miners and Merchants in Bourbon Mexico, 1763-1810. Cambridge: Cambridge University Press, 1971.

Braudel, Fernand. La méditerranée et le mond méditerranéen dans les temps de Phillippe II. Paris, 1949.

Breen, T.H. Tobacco Culture: The Mentality of the Great Tidewater Planters on the Eve of the Revolution. 2nd ed. Princeton: Princeton University Press, 2001.

Brennan, W.A. Tobacco Leaves: Being a Book of Facts for Smokers. Menasha, WI: Collegiate Press, 1915.

Brown, Kendall W. "Jesuit Wealth and Economic Activity with the Peruvian Economy: The Case of Colonial Southern Peru." The Americas 44, no. 1 (July 1987): 23-43.

Brown, Vera Lee. "The South Sea Company and Contraband Trade." The American Historical Review 31, no. 4 (July 1926): 662-78. 
Calleja Leal, Guillermo. 1762, La Habana inglesa: La toma de La Habana por los ingleses. Madrid: Agencia Española de Cooperación Internacional, Ediciones de Cultura Hispánica, 1991.

Campbell, Leon G. "Recent Research on Bourbon Enlightened Despotism, 1750-1824." The New Scholar 7, no. 1/2 (1978): 29-50.

Campbell, Leon. "The Military Reform in the Viceroyalty of Peru, 1762-1800." Ph. D. Diss. Gainesville: University of Florda, 1970.

Carlson, Fred A. Geography of Latin America. 3rd. New York: Prentice-Hall, 1952.

Carmagnani, Marcelo. "La oposición a los tributos en la segunda mitad del siglo XVII." Revista chilena de historia y geografia 129 (1961): 158-95.

Casanovas, Joan. Bread, or Bullets! Urban Labor and Spanish Colonialism in Cuba, 1850-1898. Pittsburgh: University of Pittsburgh Press, 1998.

Caulfield, Sueanne. "The History of Gender in the Historiography. of Latin America." Hispanic American Historical Review 81 (August-November 2001): 477-81.

Cepero Bonilla, Raúl. Azúcar y abolición (Apuntes para una historia crítica del abolicionismo. La Habana: Editorial Cenit, 1948.

-----. Obras históricas. La Habana: Instituto de Historia, 1963.

Chaunu, Pierre, and Hugette Chaunu. Séville et l' Atlantique, 1504-1650. Vol. 9 vols. Paris, 1955-60.

Christelow, Allan. "Contraband Trade Between Jamaica and the Spanish Main, and the Free Port Act of 1766." Hispanic American Historical Review 22, no. 2 (May 1942): 309-43.

Cigar Institute of America. The Story of Cigars. New York: Cigar Instititute of America, 1942.

Clark, William J. Commercial Cuba: A Book for Business Men. New York: Charles Scribner's Son, 1898.

Clemens, Paul G.E. The Atlantic Economy and Colonial Maryland's Eastern Shore: From Tobacco to Grain. Ithaca: Cornell University Press, 1980. 
Coatsworth, John H. "The Mexican Mining Industry in the Eighteenth Century." In The Economies of Mexico and Peru During the Late Colonial Period, 1760-1810, edited by Nils Jacobsen and Hans-Jürgen Puhle, 26-45. Berlin: ColloquiumVerlag, 1986.

Cohen, Jeremy. "Smuggling in Eighteenth-Century Venezuela: The Role of the Práctico." Latin American Studies Association. Dallas, TX, 2003.

Coker, William S. "Diaster to Victory: The Reign of Charles III and Its Effect Upon $L a$ Florida." In Charles III: Florida and the Gulf, 19-33. Coral Gables, Florida: Count of Gálvez Historical Society, 1990.

Conde Armildez de Toledo. "Noticias estadisticas de la Isla de Cuba en 1862, dispuestas y publicadas por el centro de estadistica." Habana: Imprenta del Gobierno, Capitania General y Real Hacienda por S.M., 1864.

Cooney, Jerry W. "La Dirección General de la Real Renta de Tabacos and the Decline of the Royal Tobacco Monopoly in Paraguay, 1779-1800." Colonial Latin American Historical Review 1, no. 1 (Fall 1992): 101-15.

Cope, R. Douglas. The Limits of Racial Domination: Plebeian Society in Colonial Mexico City, 1660-1720. Madison: The University of Wisconsin Press, 1994.

Corbitt, Duvon Clough. "The Colonial Government of Cuba." PhD dissertation. Chapel Hill: University of North Carolina, 1938.

Cosner, Charlotte A. "The U.S. Embargo of Cuba Under the Clinton Administration: A Historical Review and Projections for Its Future." Unpublished master's thesis. Coral Gables, Florida: University of Miami, 1997.

Coutts, Brian E. "Boom and Bust: The Rise and Fall of the Tobacco Industry in Spanish Louisiana, 1770-1790." The Americas: A Quarterly Review of Inter-American Cultural History 42, no. 3 (January 1986): 289-309.

Córdova, Efrén. El trabajo forzoso en Cuba (Un recorrido amargo de la historia). Miami: Ediciones Universal, 2001.

Crawford, John. "On the History and Consumption of Tobacco." Journal of the Statistical Society of London 16, no. 1 (March 1853): 45-52.

Cuadrado Melo, Manuel. Obispado de la Habana su historia a traves de los siglos. Vol. 1, part 1A, 1970. 
Curtin, Philip D. The Rise and Fall of the Plantation Complex: Essays in Atlantic History. 2nd ed. Cambridge: Cambridge University Press, 1998.

Cushner, Nicholas P. Farm and Factory: The Jesuits and the Development of Agrarian Capitalism in Colonial Quito, 1600-1767. Albany: State University of New York Press, 1982.

-----. Jesuit Ranches and The Agricultuaral Development of Colonial Argentina, 16501767. Albany: State University of New York Press, 1983.

--.-.. Lords of the Land: Sugar, Wine, and Jesuit Estates of Coastal Peru, 1600-1767. Albany: State University of New York Press, 1980.

Dabney, Virginius. Virginia: The New Dominion. 1971. Charlottesville: University Press of Virginia, 1996.

Dana, Richard Henry. To Cuba and Back: A Vacation Voyage. Boston: Ticknor and Fields, 1859.

Davies, K.G. The North Atlantic World in the Seventeenth Century. Minneapolis: University of Minnesota Press, 1974.

de Gordon y de Acosta, Antonio. El tabaco en Cuba: Apuntes para su historia. La Habana: Tipografia "La Propaganda Literatura", 1897.

de Jesus, Ed.C. The Tobacco Monopoly in the Philippines: Bureaucratic Enterprise and Social Change 1760-1880. Manila: Ateneo de Manila University Press, 1980.

de la Pezuela, Jacobo. "Estado general de la produccion agricola y riqueza rural de la isla correspondiente al año de 1861." In Diccionario geográfico, estadistico, histórico de la Isla de Cuba, Vol. 1, 38-39. Madrid: Imprenta del Establecimiento de Mallado, 1863.

-.---.. "Tabaco." In Diccionario geográfico, estadistico, histórico de la Isla de Cuba, Vol. 4. Madrid: Imprenta del Establecimiento de Mallado, 1867.

de la Sagra, Ramón. Historia economico-politica y estadistica de la Isla de Cuba ó sea de sus progresos en la población, la agricultura, el comercio y las rentas. Habana: Imprenta de las Viudas de Arazoza y Soler, 1831.

-----. Historia fisica, politica y natural de la isla de Cuba. Paris: A. Bertrand, 1839.

de Paula Arias, Antonio María. El veguero de Vuelta Abajo. Apuntes sobre el cultivo del tabaco. Pinar del Río, Cuba: Imprenta de Miguel Vives, 1887. 
de Paula Sanz, Francisco. Viaje por el Virreinato del Río de la Plata: El camino del tabaco. Buenos Aires: Centro de Estudios Interdisciplinarios de Hispanoamérica Colonial, 1977.

Deans-Smith, Susan. Bureaucrats, Planters, and Workers: The Making of the Tobacco Monopoly in Bourbon Mexico. Austin: University of Texas Press, 1992.

---.- "The Money Plant: The Royal Tobacco Monopoly of New Spain, 1765-1821." In The Economies of Mexico and Peru During the Late Colonial Period, 1760-1810, Nils Jacobsen and Hans-Jürgen Puhle, 361-87. Berlin: Colloquium-Verlag, 1986.

Deive, Carlos Esteban. Las emigraciones canarias a Santo Domingo: Siglos XVII y XVIII. Santo Domingo: Fundación Cultural Dominicana, 1991.

Dimock, Joseph Judson. Impressions of Cuba in the Nineteenth Century: The Travel Diary of Joseph J. Dimock. Edited by Louis A. Jr. Perez. Wilmington: Scholarly Resources, 1998.

Din, Gilbert. The Canary Islanders of Louisiana. Baton Rouge and London: Louisiana State University Press, 1988.

Diaz, María Elena. The Virgin, the King, and the Slaves of El Cobre: Negotiating Freedom in Colonial Cuba, 1670-1780. Stanford: Stanford University Press, 2000.

Dollero, Adolfo. Cultura cubana: La provincia de Pinar del Rio y su evolucíon. La Habana: Imp. Seoane y Fernández, 1921.

-----. Cultura cubana (La provincia de Pinar del Río y su evolución). Habana: Impresora Seoane y Fernández, 1921.

Ehrlich, Eugene, Stuart Berg Flexner, Gorton Carruth, and Joyce M. Hawkins, eds. Oxford American Dictionary. New York: Avon Books, 1980.

Elkins, Stanley M. Slavery: A Problem in American Institutional and Intellectual Life. $2 \mathrm{~d}$ ed. Chicago: University of Chicago Press, 1968.

Eltis, David. "Atlantic History in Global Perspective." Itinerario 23, no. 2 (1999).

Escobar Guío, Francisco. "Naufragios en la Bahía de La Habana en el período colonial." In La Habana, puerto colonial siglos XVIII-XIX, edited by Agustín Guimerá, Fernando Monge, 227-43. Madrid: Fundación Portuaria, 2000. 
“Establiciendo una Compañía en San Cristóbal de la Habana Dedicada a la Conducción de Tabacos, Azúcar, Corambre y Otros Frutos de la Isla de Cuba." In Cedulario Americano del Siglo XVIII. Vol. 3, Cédulas de Luis I (1724), Cédulas de Felipe V (1724-1746), edited by Antonio Muro Orejon, 253-76. Sevilla: Escuela de Estudios Hispano-Americanos, 1740.

Fairholt, F.W. Tobacco: Its History and Associations: Including an Account of the Plant and Its Manufacture; with Its Modes of Use in All Ages and Countries. London: Chapman and Hall, 1859.

Fallas, Marco Antonio. La Factoría de tabacos de Costa Rica. San Jose: Editorial Costa Rica, 1972.

Feliciano Ramos, Héctor R. "El comercio de contrabando en la costa sur de Puerto Rico 1750-1778." Revista/Review Interamericana 14, no. 1-4 (primavera-invierno 1984): 80-99.

Felipe V. "Instrucción dada por Felipe V el día 11 de abril de 1717 para el estanco de tabaco." in Documentos para la historia de Cuba, vol. 1, Hortensia Pichardo, 147-48. La Habana: Editorial de Ciencias Sociales, 1971.

Fernández Miñano, Martín. "Cultura de tabaco en la isla de Cuba." Manuscript, Audiencia de Santo Domingo, Legajo 2002. Archivo General de Indias, 1788.

Ferrer, Ada. Insurgent Cuba: Race, Nation, and Revolution, 1868-1898. Chapel Hill and London: The University of North Carolina Press, 1999.

Firestone, Harry, ed. Bacon's Rebellion: The Contemporary News Sheets. Charlottesville: University of Virginia Press, 1956.

Friedlaender, H.E. Historia economica de Cuba. Vol. 14. La Habana: Jesus Montero, 1944.

García Galló, Gaspar Jorge. Biografía del tabaco habano. La Habana: Universidad Central de Las Villas, Departamento de Relaciones Culturales, 1959.

García Rodríguez, Mercedes. "Presencia Jesuita en la Economía de Cuba: Siglo XVIII." Ph. D. Diss. Havana, Cuba: Universidad de la Habana, 1999.

Garner, Wightman W. The Production of Tobacco. Philadelphia: Blakiston Company, 1946.

Gillespie, Kate, and J. Brad McBride. "Smuggling in Emerging Markets: Global Implications." The Columbia Journal of World Business 31 (Winter 1996): 40-54. 
Goizueta-Mimó, Félix. Azúcar amargo cubano: monocultivo y dependencia economica. Madrid: Instituto de Sociologia y Desarrollo del Area Iberica, 1972.

González Enciso, Agustín. "Los Usos Financieros del Tabaco; o Bien, para Qué Servían los Dineros Obtenidos con la Renta del Tabaco." In El Mercado del Tabaco en España Durante el Siglo XVIII: Fiscalidad y Consumo, edited by Santiago de Luxán Meléndez, Sergio Solbes Ferri and Juan José Laforet, 25-51. Las Palmas de Gran Canaria: Universidad de Las Palmas de Gran Canaria Servicio de Publicaciones, 2000.

González, Reynaldo. "Los Primeros Pasos del Tabaco." Casa de las Américas 27, no. 158 (1986): 123-31.

Goodman, Jordan. Tobacco in History: The Cultures of Dependence. London: Routledge, 1993.

Gornes Mac-Pherson, M.J. De la conquista a nuestros dias: Historia del tabaco. Caracas: Editorial "Elite", 1933.

Gould, Eliga H. "Entangled Histories, Entangled Worlds: The English-Speaking Atlantic as a Spanish Periphery." American Historical Review 112, no. 3 (June 2007): 76499.

Grahn, Lance R. “An Irresoluble Dilemma: Smuggling in New Granada, 1713-1763." In Reform and Insurrection in Bourbon New Granada and Peru, eds. Allan J. Kuethe John R. Fisher, and Anthony McFarlane, 123-46. Baton Rouge, LA: Louisiana State University Press, 1990.

Grames, Alison. "Introduction, Definitions, and Historiography: What Is Atlantic History?" OAH Magazine of History 18 (April 2004): 3-7.

Gray, L.C. "The Market Surplus Problems of Colonial Tobacco." William and Mary Quarterly 2nd series, 12, no. 4 (October 1927): 231-45.

Greene, Jack P. "Beyond Power: Paradigm Subversion and Reformulation and the ReCreation of the Early Modern Atlantic World." In Interpreting Early America: Historiographical Essays, Jack P. Green, 17-42. Charlottesville: University of Virginia Press, 1996.

Guerra y Sánchez, Ramiro. Azúcar y población en las Antillas, 1927.

-1-.-. Manual de historia de Cuba. 6th. 1921. La Habana: Editorial Pueblo y Educación, 1980. 
----. Sugar and Society in the Caribbean: An Economic History of Cuban Agriculture. With a foreword by Sidney W. Mintz. Caribbean Series. New Haven and London: Yale University Press, 1964.

Guerra y Sánchez, Ramiro, José M. Pérez Cabrera, Juan J. Remos, and Emeterio S. Santovenia. Historia de la nación cubana. Vol. 2, Guerras coloniales conflictos y progresos (desde 1697 hasta 1790). La Habana: Editorial Historia de la Nacion Cubana, 1952.

-----. Historia de la nación cubana. Vol. 3, Ilustración libertad de comercio (desde 1790 hasta 1837). La Habana: Editorial Historia de la Nacion Cubana, 1952.

Gutiérrez Escudero, Antonio. "El tabaco en Santo Domingo y su exportación a Sevilla (época colonial)." In Relaciones de poder y comercio colonial: nuevas perspectivas, edited by Enriqueta Vila Vilar, Allan J. Kuethe, 117-42. Sevilla: Escuela de Estudios Hispano-Americanos de Sevilla, 1999.

Gutman, Herbert G. The Black Family in Slavery and Freedom, 1750-1925. New York: Vintage Books, 1976.

Hanson, Carl A. "Monopoly and Contraband in the Portuguese Tobacco Trade, 16241702." Luso-Brazilian Review 19, no. 2 (Winter 1982): 149-68.

Harrison, John P. "The Evolution of the Colombian Tobacco Trade, to 1875." Hispanic American Historical Review 32, no. 2 (May 1952): 163-74.

Hazard, Samuel. Cuba with Pen and Pencil. 1871. Miami: Editorial Cubana, 1989.

Helg, Aline. Our Rightful Share: The Afro-Cuban Struggle for Equality, 1886-1912. Chapel Hill: University of North Carolina Press, 1995.

Hernández García, Julio. La emigración canaria contemporánea (Siglo XIX). Las Palmas: Ediciones del Cabildo Insular de Gran Canaria, 1987.

Hernández González, Manuel Vicente. La colonización de la frontera dominicana 16801795. Santo Domingo: Editora Búho, 2006.

Hernández González, Manuel. Canarias: la emigración. La Laguna, Tenerife: Impecan, 1995.

-----. Los canarios en la Venezuela colonial (1670-1810). Tenerife, Canary Islands:

Taller de Historia, 1999. 
Herndon, G. Melvin, ed. William Tatham and the Culture of Tobacco. Coral Gables, FL: University of Miami Press, 1969.

Hinckley, Theodore C. "The Decline of Caribbean Smuggling." Journal of InterAmerican Studies 5, no. 1 (January 1963): 107-21.

Hobsbawm, E.J. "The Historian Between the Quest for the Universal and the Quest for Identity." In The Social Responsibility of the Historian, edited by François Bédarida, 51-63. Providence, RI: Berghahn Book, 1994.

Humbolt, Alexander. The Island of Cuba. Translated by J.S. Thrasher. New York: Derby and Jackson, 1856.

Iglesias, Fé. La estructura agrária en el occidente de Cuba 1700-1750, Manuscript in preparation.

Inglis, Gordon Douglas. "Historical Demography of Colonial Cuba, 1492-1780." Ph. D. Diss. Fort Worth, TX: Texas Christian University, 1979.

Jiménez Pastrana, Juan. La rebelión de los vegueros. La Habana: Editorial Gente Nueva, 1979.

Johnson, Paul R. The Economics of the Tobacco Industry. New York: Prageger, 1984.

Johnson, Sherry. "La Guerra Contra los Habitantes de los Arrabales': Changing Patterns of Land Use and Land Tenancy in and Around Havana, 1763-1800." Hispanic American Historical Review 77, no. 2 (1997): 181-209.

-..-... El Niño's Atlantic World Reprecussions in the Age of Revolution, in progress.

----. "Señoras en Sus Clases no Ordinarias': Enemy Collaborators or Courageous Defenders of the Family?" Cuban Studies/Estudios Cubanos 34 (2004): 25-30.

-.---. The Social Transformation of Eighteenth-Century Cuba. Gainesville: The University Press of Florida, 2001.

-----. "Where Has All the Flour Gone? El Niño, Environmental Crisis and the Emergence of Alternative Markets in the Hispanic Caribbean 1760s-1770s." William and Mary Quarterly 62, no. 3 (July 2005): 365-410.

Karasch, Mary. "Slave Women on the Brazilian Frontier in the Nineteenth Century." In More Than Chattel: Black Women and Slavery in the Americas, edited by Darlene Clark Hine, Jr. John McCluskey, Barry David Gaspar, 79-96. Bloomington and Indianapolis: Indiana University Press, 1996. 
Karras, Alan L., and J.R. McNeill, eds. Atlantic American Societies: From Columbus Through Abolition, 1492-1888. London and New York: Routledge, 1992.

Kiple, Kenneth F. Blacks in Colonial Cuba 1774-1899. Latin American Monographs, 2nd Series. Gainesville: University Presses of Florida, 1976.

Klein, Herbert S. Slavery in the Americas: A Comparative Study of Virginia and Cuba. Chicago: University of Chicago Press, 1967.

Klooster, Willem Wubbo. "Mlicit Riches: The Dutch Trade in the Caribbean, 16481795." Ph. D. Diss. Netherlands: Rijksuniversiteit te Leiden, 1995.

Knight, Franklin W. Slave Society in Cuba During the Nineteenth Century. Madison: The University of Wisconsin Press, 1970.

Kolchin, Peter. American Slavery, 1619-1877. New York: Hill and Wang, 1993.

Kuethe, Allan J. Cuba, 1753-1815: Crown, Military, and Society. Knoxville: The University of Tennessee Press, 1986.

-----. "The Development of the Cuban Military as a Sociopolitical Elite, 1763-83." Hispanic American Historical Review 61, no. 4 (1981): 695-704.

Kuethe, Allan J., and G. Douglas Inglis. "Absolutism and the Enlightened Reform: Charles III, the Establishment of the Alcabala, and Commercial Reorganization in Cuba." Past and Present: A Journal of Historical Studies 109 (November 1985): 118-43.

Kulikoff, Alan. Tobacco and Slaves: The Development of Southern Cultures in the Chesapeake, 1680-1800. Chapel Hill: University of North Carolina Press, 1986.

Lavrin, Asunción, and Edith B. Courturier. "Dowries and Wills: A View of Women's Socioeconomic Role in Colonial Guadalajara and Puebla, 1640-1790." Hispanic American Historical Review 59, no. 2 (1979): 280-304.

Lewis, James A. "Anglo-American Entrepreneurs in Havana: The Background and Significance of the Expulsion of 1784-1785." In The North American Role in the Spanish Imperial Economy, 1760-1819, edited by Jacques A. Barbier and Allan J. Kuethe, 112-26. Manchester, England: Manchester University Press, 1984.

-...-. "The Royal Gunpowder Monopoly in New Spain: 1766-1783: A Case Study of Management, Technology, and Reform Under Charles III." Ibero-Amerikanisches Archiv 6, no. 4 (neue Folge 1980): 355-72. 
Lopez Mendez, Lino. Manual del veguero venezolano. Cultivo del tabaco segun los mejores metodos empleados en Cuba y adaptados a la practica en Venezuela. Cáracas: Imprenta al Vapor de "La Opinion Nacional", 1883.

Lorenzo, Antonio, Marcial Morera, and Gonzalo Ortega. Diccionario de canarismos. La Laguna: Francisco Lemus, 1995.

Lorimer, Joyce. "The English Contraband Tobacco Trade in Trinidad and Guiana, 15901617." In The Westward Enterprise: English Activities in Ireland, the Atlantic, and America 1480-1650, edited by K.R. Andrews, N.P Canny, and P.E.H. Hair, 124-50. Liverpool: Liverpool University Press, 1978.

Lucas, George B. Diseases of Tobacco. New York: The Scarecrow Press, 1958.

Lugar, Catherine. "The Portuguese Tobacco Trade and Tobacco Growers of Bahia in the Late Colonial Period." In Essays Concerning the Socioeconomic History of Brazil and Portuguese India, Dauril Alden and Warren Dean, 26-70. Gainesville: The University Presses of Florida, 1977.

Luján Muñoz, Jorge. "El establecimiento del Estanco del Tabaco en el Reino de Guatemala." V Congreso Centroamericano de Historia. San Salvador, El Salvador, 2000.

Lynch, John. Bourbon Spain, 1700-1808. Oxford, UK: Basil Blackwell, 1989.

----. Spanish Colonial Administration, 1782-1810: The Intendent System in the Viceroyalty of the Río de la Plata. London: Univeristy of London, 1958.

MacInnes, C.M. The Early English Tobacco Trade. London: Kegan Paul, Trench, Trubner, and Company, 1926.

Macías Hernández, Antonio M. La migración canaria, 1500-1980. Colombres, Spain: Ediciones Júcar, 1992.

Macle Cruz, Jorge. "La tormenta de San Francisco de Borja." Boletín del Archivo Nacional 12 (2000): 75-107.

Marichal, Carlos. Bankruptcy of Empire: Mexican Silver and the Wars Between Spain, Britain, and France 1760-1810. Cambridge: Cambridge University Press, 2007.

Marrero, Leví. Cuba: economía y sociedad. Vol. 9, Azucar, ilustración y conciencia (1763-1868) (I). Madrid: Editorial Playor, 1983. 
-.-.-. Cuba: economía y sociedad. Vol. 11, Azúcar, ilustración y conciencia (1763-1868) (III). Madrid: Editorial Playor, 1984.

-----. Cuba: economía y sociedad. Vol. 13, Azucar, ilustración y conciencia (1763-1868) (V). Madrid: Editorial Playor, 1986.

----. Cuba: economía y sociedad. Vol. 6, Del monopolio hacia la libertad comercial (1701-1763) (I). Madrid: Editorial Playor, 1978.

---.-. Cuba: economía y sociedad. Vol. 7, Del monopolio hacia la libertad comercial (1701-1763) (II). Madrid: Editorial Playor, 1978.

----.. Cuba: economía y sociedad. Vol. 8, Del monopolio hacia la libertad comercial (1701-1763) (III). Madrid: Editorial Playor, 1980.

-----. Cuba: Economía y sociedad. Vol. 4, El siglo XVII (11). Madrid: Editorial Playor, 1975.

Marshall, Woodville K. "Provision-Ground and Plantation Labour in Four Windward Islands: Competition for Resources During Slavery." Slavery Abolition 12, no. 1 (May 1991): 48-67.

Martínez-Alier, Verena. Marriage, Class and Colour in Nineteenth-Century Cuba: A Study of Racial Attitudes and Sexual Values in a Slave Society. Cambridge, England: Cambridge University Press, 1974.

Martínez-Fernández, Luis. Fighting Slavery in the Caribbean: The Life and Times of a British Family in Nineteenth-Century Havana. Armonk, NY: M.E. Sharpe, 1998.

-----. "The 'Male City' of Havana: The Coexisting Logics of Colonialism, Slavery, and Patriarchy in Nineteenth-Century Cuba." In Women and the Colonial Gaze, edited by Tamara L. Hunt and Micheline R. Lessard, 104-16. New York: New York University Press, 2002.

Marx, Robert F. The Capture of the Treasure Fleet: The Story of Piet Heyn. New York: David McKay and Company, 1977.

McAlister, Lyle N. The "Fuero Militar" in New Spain, 1764-1800. Gainesville: University of Florida Press, 1957.

McFarlane, Anthony. Colombia Before Independence: Economy, Society, and Politics Under Bourbon Rule. Cambridge Latin American Studies. Cambridge: Cambridge University Press, 1993. 
McManus, Jane. Getting to Know Cuba: A Travel Guide. New York: St. Martin's Press, 1989.

McNeill, John Robert. Atlantic Empires of France and Spain: Louisbourg and Havana, 1700-1763. Chapel Hill: University of North Carolina Press, 1985.

McWaters, David Lorne. "The Royal Tobacco Monopoly in Bourbon Mexico, 17641810." Ph. D. Diss. Gainesville: University of Florida, 1979.

Meining, D.W. The Shaping of America: A Geographical Perspective on 500 Years of History. Vol. 1, Atlantic America 1492-1800. New Haven: Yale University Press, 1986.

Mesa-Lago, Carmelo. "Three Decades of Studies on the Cuban Revolution: Progress, Problems, and the Future." In Cuban Studies Since the Revolution, edited by Mark Fernández, with a foreword by Mark Rosenberg, 9-44. Gainesville, FL: University Press of Florida, 1992.

"Methodo de sembrar y cosechar el Tabaco en la Ysla de Cuba," Audiencia de Santo Domingo, Legajo 2002. Archivo General de Indias, n.d.

Middleton, Arthur Pierce. "The Chesapeake Convoy System, 1662-1763." William and Mary Quarterly 3rd ser.3, no. 2 (April 1946): 182-207.

Minor, Peter. Notes on the Cultivation and Management of Tobacco, from the Plant Bed to the Prize; According to the Most Approved Practices in Albemarle, and the Adjacent Counties in Virginia. Baltimore: J. Robinson, 1822.

Mohl, Raymond A., ed. “A Scotsman in Cuba, 1811-1812." The Americas 29, no. 2 (1972): 232-45.

Mora de Tovar, Gilma Lucía. Aguardiente y conflictos sociales en la Nueva Granada durante el siglo XVIII. Bogotá: Universidad Nacional de Colombia, Centro Editorial, 1988.

Moreno Fraginals, Manuel. El ingenio: complejo económico social cubano del azúcar. La Habana: Editorial de Ciencias Sociales, 1978.

-..--.. The Sugarmill: The Socioeconomic Complex of Sugar in Cuba, 1760-1860. Translated by Cedric Belfrage. New York: Monthly Review Press, 1976.

Morton, William. "Diaries." Diary. Mss2 M8464 b. William Morton Papers. Virginia Historical Society, 1846 and 1847. 
Mota, Francisco M. Piratas y corsarios en las costas de Cuba. Ciudad de la Habana: Editorial Gente Nueva, c. 1977.

Nash, Robert C. "The English and Scottish Tobacco Trade in the 17th and 18th Centuries: Legal and Illegal Trade.". Economic History Review 35, no. 3 (1982): 354-72.

Náter, Laura. "El negocio colonial de tabaco en el Imperio Español." Social Science History Institute. Stanford University, 2001.

-----. "The Spanish Empire and Cuban Tobacco During the Seventeenth and Eighteenth Centuries." In The Atlantic Economy During the Seventeenth and Eighteenth Centuries: Organization, Operation, Practice, and Personnel, edited by Peter A. Coclanis, 252-76. Columbia: University of South Carolina Press, 2005.

Nelson, George H. "Contraband Trade Under the Asiento, 1730-1739." The American Historical Review 51, no. 1 (October 1945): 55-67.

Nieto y Cortadellas, Rafael. Dignidades nobiliarias en Cuba. Madrid: Ediciones Cultura Hispanica, 1954.

Nobiatur, J.F. El veguero practico y cientifico, o sea Cultivo perfeccionado del tabaco con el méthodo de preparar convenientemente la hoja, para sus más ventajosa elaboracion, todo con arreglo á kis adelantados modernos. Habana: El Telegrafo, 1874.

Norton, Marcy. "The Business of Tobacco in the Spanish Empire, 1590-1636." Working Paper No. 99-00 in International Seminar on the History of the Atlantic World, 1500-1800. Working Papers. Cambridge: Harvard University, 1998.

Ogelsby, J.C.M. "Spain's Havana Squadron and the Preservation of Power in the Caribbean, 1740-1748." Hispanic American Historical Review 49, no. 3 (August 1969): 473-88.

Ortiz, Fernando. Cuban Counterpoint: Tobacco and Sugar. Translated by Harriet de Onís. With an introduction by Bronislaw Malinowski, prologue by Herminio Portell Vilá, new introd by Fernando Coronil. 1947. Durham: Duke University Press, 1995.

Palmer, Colin A. Slaves of the White God: Blacks in Mexico, 1570-1650. Cambridge: Harvard University Press, 1976. 
Paquette, Robert L. Sugar is Made with Blood: The Conspiracy of La Escalera and the Conflict Between Empires Over Slavery in Cuba. Middletown, CT: Wesleyan University Press, 1988.

Parcero Torre, Celia María. La pérdida de la Habana y las reformas borbónicas en Cuba, 1760-1773. Madrid: Consejo de Castilla y León, 1998.

Pares, Richard. War and Trade in the West Indies, 1739-1763. Oxford: The Clarendon Press, 1936.

Parry, J.H. The Age of Reconnaissance: Discovery, Exploration and Settlement 14501650. Berkeley: University of California Press, 1963; reprint 1981.

Parsons, James J. Hispanic Lands and Peoples: Selected Writings of James J. Parsons. William M. Denevan. Dellplain Latin American Studies. Boulder, CO: Westview Press, 1989.

Perdomo, José E. Léxico tabacalero cubano. 1940. Miami: Ediciones Universal, 1998.

Pérez, Louis A., Jr., ed. Slaves, Sugar, and Colonial Society: Travel Accounts of Cuba, 1801-1899. Wilmington, Delaware: Scholarly Resources, 1992.

---.. Cuba: Between Reform and Revolution. 2nd ed. New York: Oxford University Press, 1995.

----. Essays on Cuban History: Historiography and Research. Gainesville: University Press of Florida, 1995.

-.-.-. On Becoming Cuban: Identity, Nationality, and Culture. Chapel Hill and London: The University of North Carolina Press, 1999.

----.. "Twenty-Five Years of Cuban Historiography: Views from Abroad." Cuban Studies 18 (1988): 87-101.

-.--.. Winds of Change: Hurricanes and the Transformation of Nineteenth Century Cuba. Chapel Hill: University of North Carolina Press, 2001.

Pérez Vidal, José. España en la historia del tabaco. Madrid: Imprenta Samarán, 1959.

Pérez-Beato, Manuel. Habana antigua. Vol. 1, Toponomia. Habana: Seoane, Fernández y Ca., 1936.

Phillips, Carla Rahn. Six Galleons for the King of Spain: Imperial Defense in the Early Seventeenth Century. Baltimore: Johns Hopkins Press, 1986. 
Ponte Domínguez, Francisco J. La junta de la Habana en 1808 (Antecedentes para la historia de la autonomía colonial en Cuba). Havana: Editorial Guerrero, 1947.

Price, Jacob M., ed. "Richard Claiborne's Own Account of the Scheme to Introduce Virginia Tobacco Cultivation Into Poland, 1791." Virginia Magazine of History and Biography 83, no. 4 (October 1975): 422-27.

--.-. France and the Chesapeake: A History of the French Tobacco Monopoly. Vol. 12. Ann Arbor: University of Michigan Press, 1973.

Rediker, Marcus. "'Under the Banner of King Death': The Social World of AngloAmerican Pirates, 1716 to 1726." William and Mary Quarterly 3rd series 38, no. 2 (April 1981).

Reid, Michele Bernita. "Negotiating a Slave Regime: Free People of Color in Cuba; 1844-1868." Ph. D. Diss. Austin, TX: University of Texas at Austin, 2004.

Rive, Alfred. "A Brief History of Regulation and Taxation of Tobacco in England." William and Mary Quarterly 2nd ser. 9, no. 2 (April 1929): 73-87.

Le Riverend Brusone, Julio. La Habana, espacio y vida. Madrid: Editorial MAFRE, 1992.

-----. Historia económica de Cuba. Barcelona: Ediciones Ariel, 1972.

Rivero Muñiz, José. Tabaco: Su historia en Cuba. Vol. 1-2. Havana: Instituto de Historia, 1964-65.

-.---. Las tres sediciones de los vegueros en el siglo XVIII. La Habana: Academia de la Historia de Cuba, 1951.

Robert, Joseph C. The Story of Tobacco in America. Chapel Hill: University of North Carolina Press, 1967.

Robert, Joseph Clarke. The Tobacco Kingdom: Plantation, Market, and Factory in Virginia and North Carolina, 1800-1860. NC: Duke University Press, 1938. Gloucester, MA: Peter Smith, 1965.

Robicsek, Francis. The Smoking Gods: Tobacco in Maya Art, History, and Religion. With a foreword by Michael D. Coe and Barbara A. Goodnight. Norman: University of Oklahoma Press, 1978.

Rodríguez Gordillo, José M. Un archivo para la historia del tabaco. Madrid: Jacaryan, 1984. 
Rodríguez, José Luis. "The Antecedents and Theoretical Characteristics of Cubanology." In Cuban Political Economy, edited by Andrew Zimbalist, 22-35. Boulder, CO: Westview Press, 1988.

Rodríguez-Ferrer, Miguel. El tabaco habano: su historia, su cultivo, sus vicisitudes, sus más afamadas vegas en Cuba. Madrid: Imprenta del Colegio Nacional de SordoMudos, 1851.

Romeu Palazuelos, Enrique, Leopoldo de la Rosa Olivera, and Antonio Miguel Bernal Rodríguez. Las islas canarias. Madrid: Espasa-Calpe, 1981.

Salinger, Pierre. "Kennedy, Cuba, and Cigars." Cigar Aficionado, Autumn 1992.

Saloutos, Theodore. "Efforts at Crop Control in Seventeenth Century America." Journal of Southern History 12, no. 1 (February 1946): 45-66.

Salvucci, Linda K. "Anglo-American Merchants and Strategems for Success in Spanish Imperial Markets, 1783-1807." In The North American Role in the Spanish Imperial Economy, 1760-1819, edited by Jacques A. Barbier, Allan J. Kuethe, 127-33. Manchester, England: Manchester University Press, 1984.

Sanchez, Joseph P. "African Freedmen and the Fuero Militar: A Historical Overview of Pardo and Moreno Militiamen in the Late Spanish Empire." Colonial Latin American Historical Review, Spring 1994, 165-205.

Sanders, G. Earl. "Counter-Contraband in Spanish America: Handicaps of the Governors in the Indies." The Americas: A Quarterly Review of Inter-American Cultural History 34, no. 1 (July 1977): 59-80.

Santovenia, Emeterio S. Pinar del Río. Mexico: Fondo de Cultura Economica, 1946.

Schroeder, Susan. Cuba: A Handbook of Historical Statistics. Boston: G.K. Hall, 1982.

Schwartz, Stuart B. Slaves, Peasants, and Rebels: Reconsidering Brazilian Slavery. Urbana and Chicago: University of Illinois Press, 1992.

Schweitzer, Mary McKinney. "Economic Regulation and the Colonial Economy: The Maryland Tobacco Inspection Act of 1747." Journal of Economic History 40, no. 3 (September 1980): 551-69.

Scott, James C. Domination and the Arts of Resistance: Hidden Transcripts. New Haven: Yale University Press, 1990. 
---.- Weapons of the Weak: Everyday Forms of Peasant Resistance. New Haven: Yale University Press, 1985.

Scott, Rebecca J. "Race, Labor, and Cititzenship in Cuba: A View from the Sugar District of Cienfuegos, 1886-1909." Hispanic American Historical Review 78, no. 4 (1998): 687-728.

-----. Slave Emancipation in Cuba: The Transition to Free Labor, 1860-1899. Princeton, New Jersey: Princeton University Press, 1985.

Silver, Timothy. A New Face on the Countryside: Indians, Colonists, and Slaves in South Atlantic Forests, 1500-1800. Cambridge: Cambridge University Press, 1990.

Sintesis de geografia de Cuba. Miami, FL: Ediciones del Directorio Magisterial Cubano (en el exilio), n.d.

Socolow, Susan Midgen. The Women of Colonial Latin America. Cambridge: Cambridge University Press, 2000.

Stapff, Agnes. "La renta del tabaco en el Chile de la época virreinal." Anuario de Estudios Americanos (Seville) 18 (1961): 1-63.

Stein, Stanley J. "Bureaucracy and Business in the Spanish Empire, 1759-1804: Failure of a Bourbon Refom in Mexico and Peru." Hispanic American Historical Review 61, no. 1 (February 1981): 2-28.

Stern, Steve J. The Secret History of Gender: Women, Men, and Power in Late Colonial Mexico. Chapel Hill: University of North Carolina Press, 1995.

Stubbs, Jean. Tabaco en la perfferia. La Habana: Editorial de Ciencias Sociales, 1989.

Suárez Argüello, Clara Elena. Camino real y carrera larga: La arriería en la Nueva España durante el siglo XVIII. Mexico City: Centro de Investagiciones y Estudios Superiores en Antropología Social, Ediciones de la Casa Chata, 1997.

Syrett, David, ed. The Seige and Capture of Havana, 1762. London: Navy Records Society, 1970.

Taylor, William B. Drinking, Homicide, and Rebellion in Colonial Mexican Villages. Stanford, CA: Stanford University Press, 1979.

Thomas, Hugh. Cuba, or the Pursuit of Freedom. Updated. New York: Da Capo Press, 1998. 
Tornero Tinajero, Pablo. "Inmigrantes canarios en Cuba y cultivo tabacalero. La fundación de Santiago de las Vegas." In IV Coloquio de historia canarioamericana (1980), vol. 1, 507-29. Gran Canaria, 1982.

Torres Ramírez, Bibiano. La Compañia Gaditana de Negros. Sevilla: Escuela de los Estudios Hispano-Americanos de Sevilla, 1973.

Trouillot, Michel-Rolph. "Motion in the System: Coffee, Color and Slavery in Eighteenth-Century Saint-Domingue." Review 5, no. 3 (Winter 1982).

Tso, T.C. Physiology and Biochemistry of Tobacco Plants. Stroudsburg, PA: Dowden, Hutchinson and Ross, 1972.

Tucker, St. George. Hansford: A Tale of Bacon's Rebellion. Richmond, VA: George M. West, 1857.

Twinam, Ann. Public Lives, Private Secrets: Gender, Honor, Sexuality, and Illegitimacy in Colonial Spanish America. Stanford, California: Stanford University Press, 1999.

Van Norman, William C., Jr. "Shade Grown Slavery: Life on a Coffee Plantation in Western Cuba, 1790-1845." Ph. D. Diss. Chapel Hill, NC: University of North Carolina, 2005.

Walker, David W. "Business as Usual: The Empresa del Tabaco in Mexico, 1837-1844." Hispanic American Historical Review 64, no. 4 (November 1984): 675-705.

Warren, John Esaias. Vagamundo; or the Attaché in Spain: Including a Brief Excursion Into the Empire of Morocco. New York: Charles Scribner, 1851.

West, Robert C., and John P. Augelli. Middle America: Its Land and Peoples. 3rd ed. Englewood Cliffs, New Jersey: Prentice Hall, 1989.

Whigham, Thomas L. "Agriculture and the Upper Plata: The Tobacco Trade, 17801865." Business History Review 59, no. 4 (Winter 1985): 563-96.

Wilbert, Johannes. Tobacco and Shamanism in South America. New Haven, CT: Yale University Press, 1987.

Williams, Neville. Contraband Cargoes: Seven Centuries of Smuggling. Camden, CN: Shoe String Press, 1961.

Winter, Joseph C. Tobacco Use by Native Americans: Sacred Smoke and Silent Killer. Norman: University of Oklahoma Press, 2000. 
Wright, I.A. "The Dutch and Cuba, 1609-1643." The Hispanic American Historical Review 9, no. 4 (November 1921): 597-634.

Wurdemann, John George F. Notes on Cuba. Boston: James Munroe and Company, 1844.

Wyckoff, Vertrees J. Tobacco Regulation in Colonial Maryland. Baltimore: Johns Hopkins Press, 1936.

Zahedieh, Nuala. "The Merchants of Port Royal, Jamaica, and the Spanish Contraband Trade, 1655-1692." William and Mary Quarterly, 3rd Series 43, no. 4 (October 1986): 570-93.

Zanetti, Oscar, and Alejandro García. Sugar and Railroads: A Cuban History, 18371959. Translated by Franklin W. Knight, Mary Todd. Chapel Hill and London: The University of North Carolina Press, 1998. 


\section{CHARLOTTE A. COSNER}

1991

B.A., History

Virginia Commonwealth University

Richmond, Virginia

1997

M.A., International Studies

University of Miami

Coral Gables, Florida

2001

First place

Jay I. Kislak Foundation Student Prize Competition

2002

Lydia Cabrera Award for Cuban Historical Studies

Conference on Latin American History

Ford Foundation Grant for Student Travel

Cuban Research Institute

Florida International University

2008

Doctoral Candidate, History

Florida International University

Miami, Florida 